JACIARA DE SÁ CARVALHO

\title{
REDES E COMUNIDADES VIRTUAIS DE APRENDIZAGEM: ELEMENTOS PARA UMA DISTINÇÃO
}

Dissertação apresentada à Faculdade de Educação da Universidade de São Paulo, para obtenção do título de Mestre em Educação.

Área de Concentração: Linguagem e Educação

Orientador: Prof. Dr. Nílson José Machado

São Paulo

Abril / 2009 
Autorizo a reprodução e divulgação total ou parcial deste trabalho, por qualquer meio convencional ou eletrônico, para fins de estudo e pesquisa, desde que citada a fonte.

Catalogação na Publicação

Serviço de Biblioteca e Documentação

Faculdade de Educação da Universidade de São Paulo

371.369 Carvalho, Jaciara de Sá

C331r Redes e comunidades virtuais de aprendizagem : elementos para uma distinção / Jaciara de Sá Carvalho ; orientação Nilson José Machado. São Paulo : s.n., 2009.

196 p. : il., tabs.

Dissertação (Mestrado - Programa de Pós-Graduação em

Educação.Área de Concentração : Linguagem e Educação) - - Faculdade de Educação da Universidade de São Paulo.

1. Internet - Educação 2. Redes sociais - Educação 3. Educação a distância 4. Comunidade virtual - Educação 5. Interação social (sociologia) 6. Cooperação - Educação. I. Machado, Nilson José, orient. 


\section{FOLHA DE APROVAÇÃO}

Jaciara de Sá Carvalho

Redes e comunidades virtuais de aprendizagem: elementos para uma distinção

Dissertação apresentada à Faculdade de Educação da Universidade de São Paulo, para a obtenção do título de Mestre em Educação.

Área de Concentração: Linguagem e Educação

Aprovado em:

\section{BANCA EXAMINADORA}

Prof. Dr. Nílson José Machado (orientador)

Instituição: Faculdade de Educação da Universidade de São Paulo (FE-USP)

Ass.:

Prof $^{\mathrm{a}}$. Dra ${ }^{\mathrm{a}}$. Vani Moreira Kenski

Instituição: Universidade de Campinas (Unicamp)

Ass.:

Prof. Dr. Gilson Schwartz

Instituição: Escola de Comunicações e Artes da Universidade de São Paulo (ECA-USP) Ass.: 
"Para o meu coração, basta o teu peito"

Pablo Neruda

A Henrique de Paula Batista, para quem me calo e abro os olhos redondos. 


\section{AGRADECIMENTOS}

Antes de todos, a Deus e meus protetores, por me darem forças para enfrentar os desafios que me fazem crescer e tornar-me quem sou.

Ao meu amado orientador, por guiar-me com carinho e paciência, pelas horas de lucidez e sabedoria nas inesquecíveis manhãs de sextas-feiras.

Aos meus pais Joaquim e Antonia e minha irmã Janaina, por compreenderem minhas ausências e estimularem meus estudos.

À Prof ${ }^{a}$. Vani Moreira Kenski, que muito me ensinou sobre as comunidades virtuais de aprendizagem e para além delas.

Aos meus amigos da equipe EducaRede, que me proporcionaram aprendizagens, oportunidades e caminhos a seguir.

Aos participantes do curso "Ensinando em Ambientes Virtuais 1", da lista de discussão "Blogs Educativos" e da rede de aprendizagem online "POIEs do Butantã", que tornaram possível esta dissertação.

Aos colegas dos Seminários de Estudos em Epistemologia e Didática (SEED), em especial à doce Marisa Ortegoza.

Aos amigos do Grupo Nós: Eri, Wander, Bel e Salete (em especial) pela mobilização de nossa "inteligência coletiva".

À Sônia Dias e todos que, por meio de debates e sugestões, contribuíram com esta dissertação, principalmente os pesquisadores/autores citados neste trabalho de muitas vozes e idéias.

Ao Instituto Paulo Freire, onde empregarei as reflexões costuradas nesta dissertação. 
Para chegares ao que não sabes, Hás de ir por onde não sabes. Para chegares ao que não gozas, Hás de ir por onde não gozas. Para vires ao que não possuis, Hás de ir por onde não possuis. Para vires a ser o que não és, Hás de ir por onde não és.

\section{Modo de possuir tudo}

Para vires a saber tudo, Não queiras saber coisa alguma.

Para vires a gozar tudo, Não queiras gozar coisa alguma.

Para vires a possuir tudo, Não queiras possuir coisa alguma.

Para vires a ser tudo, Não queiras ser coisa alguma.

Modo para não impedir o tudo

Quando reparas em alguma coisa, Deixas de arrojar-te ao tudo. Porque para vires de todo ao tudo,

Hás de deixar de todo ao tudo.

E quando vieres a tudo ter, Hás de tê-lo sem nada querer.

Porque se queres ter algo em tudo, Não tens puro em Deus teu tesouro.

Indício de que se tem tudo

Nesta desnudez acha o espírito sua quietação e descanso, porque, nada cobiçando, nada o impele para cima e nada o oprime para baixo, porque está no centro de sua humildade; pois quando cobiça alguma coisa nisto mesmo se fatiga".

(São João da Cruz, Subida do Monte) 


\section{RESUMO}

\section{CARVALHO, Jaciara de Sá. Redes e comunidades virtuais de aprendizagem: elementos}

para uma distinção. 2009. 196 f. Dissertação (Mestrado em Educação) - Universidade de São Paulo, Faculdade de Educação, São Paulo, 2009.

Criado a partir do trabalho colaborativo de grupos de pessoas, o ciberespaço expressa vocação para abrigar incontáveis agrupamentos, diversos e distintos como a natureza humana. Parte desses agrupamentos tem recebido o nome de redes de aprendizagem online e comunidades virtuais de aprendizagem. Uma vez que a aprendizagem é intrínseca ao homem, em variados tempos, lugares e situações, todos os agrupamentos do ciberespaço podem proporcionar aprendizagens. Mas o fato de que há aspectos em comum na diversidade não retiraria a necessidade de estabelecer diferenças entre os agrupamentos porque não se deve confundir multiplicidade com indistinção. Nesse sentido, esta investigação buscou identificar elementos que podem distinguir as redes e comunidades virtuais de aprendizagem dos demais agrupamentos do ciberespaço. A partir da compreensão de que as palavras são signos ideológicos e que seu emprego formata a realidade (BAKHTIN, 1981), verificamos que também há distinção entre redes de aprendizagem online e comunidades virtuais de aprendizagem. A reflexão proporcionou ainda mapearmos indicadores de formação de comunidades virtuais em situação de aprendizagem. Para levantar os elementos mencionados, realizamos revisão bibliográfica e examinamos três agrupamentos do ciberespaço, apontados neste trabalho como uma rede social, uma rede de aprendizagem online e uma comunidade virtual de aprendizagem. Mais do que apresentar uma sugestão quanto ao emprego dessas expressões, esta dissertação costura uma série de reflexões sobre rede e intencionalidade educativa, certos de que rede é a metáfora mais fundamental para a Educação do século XXI.

Palavras-chave: rede, rede social, comunidade virtual, rede de aprendizagem online, aprendizagem em rede, comunidade virtual de aprendizagem, educação a distância, educação online, interação, colaboração. 


\begin{abstract}
CARVALHO, Jaciara de Sá. Netwoks and virtual learning communities: elements for a distinction. 2009, 196 f. Dissertation (Master's degree in Education) - University of São Paulo, São Paulo, 2009.
\end{abstract}

Elaborated from co-operated work by groups of people, the cyberspace expresses the vocation to shelter countless groupings, several and different as the human nature. Some of these groupings have been receiving the name of online learning networks and virtual learning communities. Once the learning is intrinsic to the man, in several times, places and situations, all groupings of the cyberspace can provide learning. But the fact that there are aspects in common in the diversity would not remove the need to establish differences among the groupings because it should not confuse multiplicity with indistinct. In that sense, this investigation looked for to identify elements that can distinguish the online learning networks and the virtual learning communities of the other groupings of the cyberspace. Starting from the understanding that the words are ideological signs and that its use formats the reality (BAKHTIN, 1981), we verified that there is also distinction between online learning networks and virtual learning communities. The reflection provided mapping of indicators of virtual communities' formation in learning situation. To survey the mentioned elements, we accomplished bibliographical revision and examined three groupings of the cyberspace, pointed in this work as a social network, an online learning network and a virtual learning community. More than to present a suggestion for the use of those expressions, this dissertation sews a series of reflections on net and educational intentionality, convinced that net is the most fundamental metaphor for the Education of the XXI century.

Keywords: networks, social networks, virtual community, online learning networks, learning in network, virtual learning communities, distance education, online education, interaction, collaboration. 


\section{LISTA DE ILUSTRAÇÕES}

Quadro 1 - Mapeamento da interação em junho no Blog da rede "POIEs do Butantã"..... 94

Quadro 2 - Mapeamento da interação no Blog entre março e agosto .............................. 94

Quadro 3 - Detalhamento da proposta da "Comunidade de Gestores"............................ 100

Quadro 4 - Comparação entre abordagens colaborativa e cooperativa ........................... 111

Quadro 5 - Fatores inerentes às dinâmicas colaborativas online ..................................... 123

Figura 1 - Reprodução da homepage da lista de discussão "Blogs Educativos"............... 57

Figura 2 - Total de mensagens da lista de discussão "Blogs Educativos" ....................... 57

Figura 3 - Primeira mensagem enviada pela pesquisadora à lista de discussão................. 58

Figura 4 - Resposta de Suzana Gutierrez enviada à lista de discussão............................... 59

Figura 5 - Mapa de competências do professor........................................................... 75

Figura 6 - Homepage do ambiente virtual da rede "POIEs do Butantã".......................... 88

Figura 7 - Página principal da ferramenta "Fórum"...................................................... 89

Figura 8 - Página da ferramenta “Arquivoteca" .............................................................. 90

Figura 9 - Página da ferramenta "Material de Estudo"................................................. 90

Figura 10 - Página da ferramenta "Bate-papo" .......................................................... 91

Figura 11 - Página da ferramenta "Blog"'..................................................................... 92

Figura 12 - Homepage do ambiente da rede "Comunidade de Gestores"........................ 98

Figura 13 - Explicação da dinâmica de formação na "Comunidade de Gestores”.............. 101

Figura 14 - Mapa da proposta da "Comunidade de Gestores”...................................... 102

Figura 15 - Dados gerais do curso EAV 1.............................................................. 112

Figura 16 - Programa e cronograma do curso EAV 1................................................ 113

Figura 17 - Temas, objetivos e atividades do curso EAV 1........................................ 114

Figura 18 - Homepage do ambiente da SITE Educacional (Moodle).............................. 114

Figura 19 - Homepage do ambiente TelEduc.............................................................. 115

Figura 20 - Homepage do ambiente LabSpace/CoLearn (Moodle)................................... 116

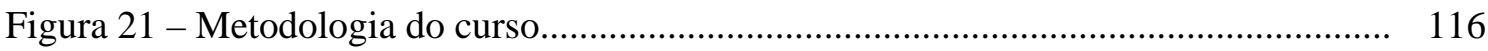

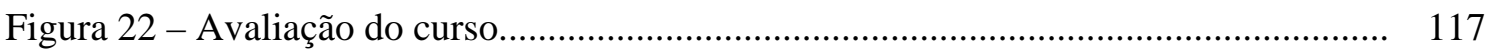

Figura 23 - Mensagens de fórum da plataforma Moodle ............................................ 121

Figura 24 - Títulos das mensagens de fórum da plataforma TelEduc............................. 121

Figura 25 - Mapa que apresentou o “Grupo Nós” e seus integrantes.............................. 151 


\section{SUMÁRIO}

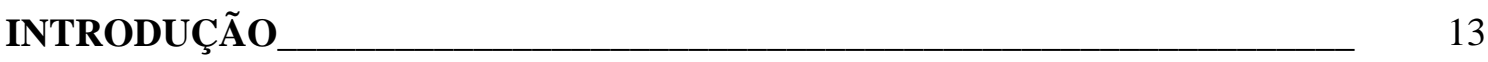

Educação e tecnologia............................................................................... 16

O início deste trabalho.......................................................................... 18

Problemática e objetivos........................................................................... 19

Metodologia e procedimentos técnicos............................................................ 21

Organização da dissertação............................................................................. 23

1. REDE E COMUNIDADE NO CIBERESPAÇO____ 26

1.1. Valores e usos das comunidades que estruturaram a Internet.................. 27

1.1.2 A Internet hoje: emaranhado de valores e usos.............................. 33

1.2 Comunidade virtual.................................................................................... 36

1.2.1. Qual comunidade? ................................................................ $\quad 40$

1.2.2. Comunidade na Pós-Modernidade.................................................. 46

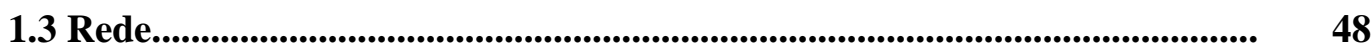

1.3.1 Rede social online ..................................................................... 51

Organização............................................................. 52

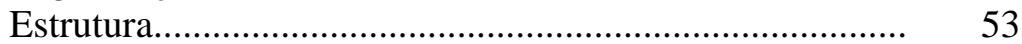

Dinâmica............................................................ 54

Rede $\mathrm{x}$ comunidade......................................................... 55

1.4 A lista "Blogs Educativos": rede e comunidade virtual............................... 56

1.4.1 Uma tentativa de distinção............................................................ 61

1.5 Redes sociais e comunidades virtuais: iguais e diferentes........................... 62

2. REDES DE APRENDIZAGEM ONLINE____ $\quad 64$

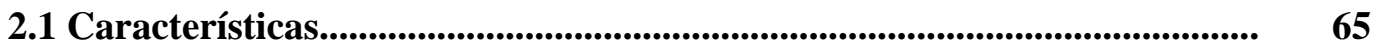


2.2 Rede e conhecimento.................................................................................................

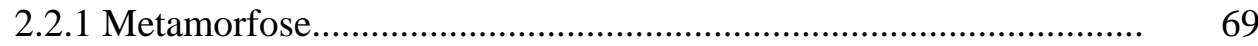

2.2.2 Heterogeneidade ........................................................................... 69

2.2.3 Multiplicidade e de encaixe de escalas.............................................. $\quad 70$

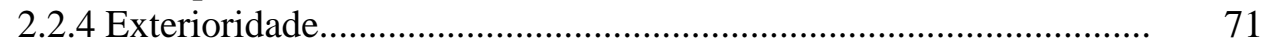

2.2.5 Topologia............................................................................ 72

2.2.6 Mobilidade dos centros.............................................................. 72

2.3 Professor: o nó robusto..........................................................................................

2.3.1 Exercer a autoridade/praticar a tolerância........................................... $\quad 75$

2.3.2 Mapear relevâncias/ tecer significações............................................ 76

2.3.3 Construir narrativas fabulosas/ mediar relações................................. 77

2.4 Cursos online como redes de aprendizagem......................................................

2.5 O desafio da interação....................................................................................... 81

2.5.1 Usos do ambiente e "personalidade eletrônica"................................ 84

2.6 Redes de aprendizagem: "POIEs do Butantã" e "Comunidade de Gestores"

2.6.1 Rede de aprendizagem online "POIEs do Butantã".......................... $\quad 87$

Análise qualitativa e quantitativa......................................... 92

Constatação...................................................................... 95

2.6.2 "Comunidade de Gestores": uma rede em construção....................... $\quad 96$

Pressupostos teóricos.......................................................... 96

Diálogo........................................................................... 98

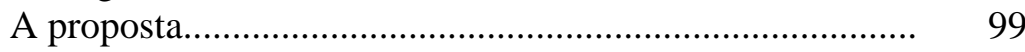

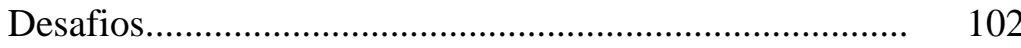

2.7 Amarrando os pontos................................................................................................. 103

3. COMUNIDADES VIRTUAIS DE APRENDIZAGEM___ 105

3.1 Revisão da literatura............................................................................................... 106

3.2 Colaboração e cooperação.................................................................................. 1110

3.3 A comunidade virtual de aprendizagem EAV 1.......................................... 111 
3.3.1 Olhar da aluna-pesquisadora.................................................... 117

Indicadores de formação de uma CVA............................... 122

Reciprocidade permanente................................... 125

Compromisso implícito......................................... 129

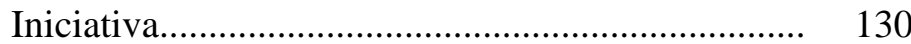

Informalidade.................................................... 132

Colaboração ......................................................... 134

Intervenção pontual do professor.......................... 139

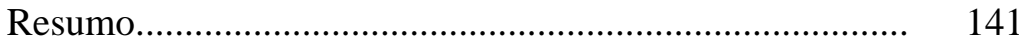

3.3.2 Olhares da professora e dos tutores ............................................ 141

Histórico do curso e dos ambientes.................................... 142

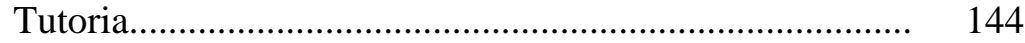

Comunidade virtual de aprendizagem? ............................ 146

Liderança ............................................................. 148

Abordagem construcionista........................................... 150

3.4 Uma costura final.......................................................................................... 152

4. Considerações finais_____

4.1 A motivação.......................................................................................................................... 156

4.2 Antes de tudo, as pessoas e a interação................................................... 157

4.3 Revendo os objetivos da pesquisa: elementos distintivos.............................. 158

APENNDICE A

171

APÊNDICE B

179

APÊNDICE C

192

APÊNDICE D

194

APÊNDICE E

196 


\section{INTRODUÇÃO}

Educação e tecnologia

O início deste trabalho

Problemática e objetivos

Metodologia e procedimentos técnicos

Organização da dissertação 


\section{INTRODUÇÃO}

Qualquer análise histórica revelaria o homem imerso em sucessivas inovações que transformam o seu modo de se comunicar, pensar e existir ao longo do tempo. Para isso, produz os meios que instrumentam sua ação, ou seja, a "técnica", e sua irmã mais nova, a "tecnologia". Tais palavras, atualmente, quase se confundem, mas, em sentido estrito, a "tecnologia", ou o estudo sobre a "técnica", não existia na Grécia antiga. Isoladamente, a "technê", que era instrumental, não se misturava com o "logos". A palavra "tecnologia" surgiu apenas no século XVIII com a Revolução Industrial e seus significados abarcam a ciência, a simples técnica, o conjunto de todas as técnicas e ainda sua ideologização (VIEIRA PINTO, 2005).

Lévy (1993) é um dos autores que empregam "tecnologia" de modo abrangente como nós -, destacando o que chama de "tecnologias da inteligência" entre as mais importantes. Classifica como tecnologia a freqüente repetição em voz alta das proposições que geria a memória das culturas orais. Tempos depois, a tecnologia escrita alterou essa gestão e o próprio pensamento, sem extinguir todos os métodos mnemônicos característicos das culturas orais. A informática, por sua vez, provoca novas alterações no pensamento e na memória humana, incorporando e transformando as outras duas tecnologias.

A informática proporcionou a interconexão mundial dos computadores e de suas memórias criando um novo espaço de comunicação. “[...] A perspectiva de digitalização geral das informações provavelmente tornará o ciberespaço o principal canal de comunicação e suporte de memória da humanidade a partir do início do próximo século (LÉVY, 1999, p. 93)". O ciberespaço é o lócus onde se situa o nosso objeto de investigação, as redes e comunidades virtuais de aprendizagem. Para alguns autores, seu surgimento resulta de uma das mais importantes inovações dos últimos séculos; para outros, o ciberespaço seria apenas mais uma nova tecnologia que coloca em xeque nossas tradições e instituições.

Esta dissertação trata do ciberespaço como uma tecnologia que pode ampliar a comunicação humana e estimular a adoção do paradigma educacional defendido há muito tempo, mas tão pouco praticado: o da aprendizagem colaborativa. A investigação concentra-se em redes de pessoas, em seus projetos, valores, atitudes e, nesse sentido, reconhece o desenvolvimento de uma nova cultura provocada pelas Tecnologias de Informação e Comunicação (TICs). Mas, antes de tudo, tenta não se submeter a um discurso que coloca a tecnologia acima do homem. 
Referimo-nos às abordagens que alertam para a incorporação das tecnologias sem crítica. Autores como Freire, Vieira Pinto e Postman apontam o fato de que a crescente velocidade das inovações tem deixado os homens cada vez mais encantados e ansiosos com as possibilidades que ainda virão. A ausência de tecnologias acaba sendo associada à pobreza, ao atraso, tornando-se quase obrigatória sua adoção. Muitas vezes, elas são incorporadas sem que se reflita a respeito, sem que se questione a serviço de que estão, já que o uso das diversas tecnologias sempre se dá a partir de um viés ideológico.

A relação com as tecnologias levou Postman (1994) a apontar três tipos de cultura presentes na humanidade. Na cultura que usa ferramentas, a tecnologia não é invasora; integra-se ao sistema de crenças e à ideologia, sem impor contradições significativas às pessoas. Incorporadas aos paradigmas medievais, por exemplo, as ferramentas não determinavam o que homem deveria fazer ou pensar; ele era guiado pelos ensinamentos de Deus. Embora ainda exista, essa cultura começa a desaparecer.

A tecnocracia "é uma sociedade vagamente controlada pelos costumes sociais e pela tradição religiosa e estimulada pelo impulso para inventar" (POSTMAN, 1994, p. 47). Referese à mentalidade do mundo moderno, no qual se acredita que conhecimento é poder.

\footnotetext{
Nós aprendemos como inventar coisas, e a questão de por que inventamos coisas perdeu importância. A idéia de que se alguma coisa podia ser feita, nasceu no século XIX. E junto com ela desenvolveu-se uma profunda crença em todos os princípios com os quais acontece a invenção: objetividade, eficiência, habilidade, padronização, medição e progresso. Também passou-se a acreditar que a máquina do progresso tecnológico trabalhava com mais eficiência quando as pessoas eram concebidas não como filhos de Deus ou mesmo cidadãos, mas como consumidores quer dizer, como mercados. (POSTMAN, 1994, p. 51, grifos do autor).
}

Segundo Postman, na tecnocracia duas visões de mundo opostas coexistem em constante tensão: a tecnológica e a tradicional. A primeira mais forte, mas a segunda resistindo e influenciando. A cultura tecnopólio acaba com essa coexistência, eliminado as demais alternativas, tornando-as invisíveis e, portanto, irrelevantes. "E o faz redefinindo o que entendemos por religião, por arte, por família, por política, por história, por verdade, por privacidade, por inteligência, de tal modo que nossas definições se adaptem às suas novas exigências" (1994, p. 57, grifo nosso). O “tecnopólio é a tecnocracia totalitária” (p. 57), resume Postman, cuja reflexão contribui não apenas para caracterizar as culturas, mas também para levar o homem a examinar sua relação com as tecnologias.

Seguindo abordagem semelhante, no campo ao qual nos situamos, da Educação, Freire incorporava tecnologias como projetor de slide, rádio, TV e outros meios eletrônicos de seu 
tempo para difundir suas idéias. Entendia que a Educação sempre empregou técnicas para educar, como a Didática, da qual depende. Mas alertava para o fato de que as inovações, assim como as antigas tecnologias, devem ser utilizadas pensando-se sob qual perspectiva as pessoas serão formadas (GADOTTI, 2000).

[...] para mim, a questão que se coloca é: a serviço de quem as máquinas e a tecnologia avançada estão? Quero saber a favor de quem, ou contra quem as máquinas estão sendo postas em uso [...] Para mim os computadores são um negócio extraordinário. O problema é saber a serviço de quem eles entram na escola. (FREIRE apud ALENCAR, 2007).

Freire e Postman contribuem com esta dissertação ao destacar o humano à frente da tecnologia, não subjugando sua ação ao discurso tecnológico inquestionável, que torna o homem maravilhado com suas próprias criações, mas esquecido da natureza e da importância do outro (VIEIRA PINTO, 2005). Já Lévy $(1993$, 1999) e outros autores que se dedicam à estudar o ciberespaço, e que serão vistos nos próximos capítulos, apontam com as possibilidades abertas pelo espaço para a ampliação da comunicação e emancipação humana.

\section{Educação e tecnologia}

Propomo-nos a investigar os agrupamentos do ciberespaço voltados para a aprendizagem, ligados à Educação. Caberia, portanto, nos perguntar a serviço de que propósito eles estariam.

O propósito das redes e comunidades virtuais de aprendizagem dependeria da visão de mundo e de Educação que norteia as atividades dos participantes. A partir do aporte teórico desta investigação, diríamos que o propósito seria o de proporcionar aprendizagens por meio de um projeto colaborativo em rede. As características dessa estrutura (rede) permitem o desenvolvimento de uma Educação dialógica, que valoriza todos os nós (os participantes) e horizontaliza a relação aluno-professor, sem que este perca sua função de orientar e estimular a aprendizagem.

Essa perspectiva coloca em destaque a interação, que, como será tratado, diz respeito à ação entre pessoas. As redes e comunidades do ciberespaço só existem e se mantém se houver interação. Tal prerrogativa favorece a Educação no ciberespaço porque o processo de ensino-aprendizagem depende da comunicação para se realizar. "A Educação é comunicação, é diálogo, na medida em que não é transferência de saber, mas de encontro de sujeitos 
interlocutores que buscam a significação dos significados (FREIRE, 1979, p. 69). A estrutura de rede potencializa esses encontros, fundamentais para a construção de conhecimento.

Claro que as redes e comunidades no ciberespaço dependem da aprendizagem dos códigos e de comportamentos desse universo que é diferente do agir face a face. Mas, aprendida a linguagem - e os jovens o fazem com desenvoltura - o meio ciberespaço também acabaria estimulando o diálogo reflexivo, visto que a escrita - principal forma de comunicação em ambientes virtuais - demanda elaboração e registro do pensamento.

De fato, as características da Educação online por meio de redes dependem das pessoas que integram esses agrupamentos, de seus objetivos, do professor e de sua intencionalidade educativa. A serviço de quem e de que o professor educa? A pergunta vale tanto para uma Educação no ciberespaço como para a sala de aula. A nossa posição é a de que esteja a serviço da emancipação das pessoas a partir de um processo colaborativo.

Freire (1996) defende uma práxis tecnológica, que desvele e desconstrua a tecnologia. Sendo aparato ideológico, faz-se necessário o exercício de observá-la, para identificar as práticas e usos que a integram e, então, combatê-los e alterá-los. É o que também acredita Postman (1994), contra o discurso de que o ensino mais "eficiente" se dá com o aperfeiçoamento de suas tecnologias. A eficiência e o aumento do interesse ao ensino seriam objetivos próprios da cultura tecnopólio; o "porquê" de torná-lo mais eficiente e interessante não necessita de respostas, já que o tecnopólio os considera fim e não meio.

Para Pretto e Assis (2008), as tecnologias não podem ser incluídas à Educação como meras ferramentas complementares e animadoras dos tradicionais processos de ensinar e de aprender. É preciso compreendê-las “como elementos fundantes das transformações que estamos vivendo, buscando ser incorporadas através de políticas públicas para a Educação que ultrapassem as fronteiras do próprio campo educacional" e, assim possa-se trabalhar "visando ao fortalecimento das culturas e dos valores locais" (PRETTO; ASSIS, 2008, p. 80).

A Educação apresenta-se como um antídoto eficaz para combater e prevenir a soberania da técnica sob a vida humana, própria da cultura tecnopólio, saturada de informação e adoradora da tecnologia. Mas não qualquer Educação e sim a que enfatiza os sentidos do que a humanidade conhece e de como conhece, por meio da análise histórica e política. E, nesse contexto, reconheça e valorize a importância da tecnologia.

No recorte deste trabalho, o ciberespaço é a inovação que amplia a interação humana, não sendo destacado como fim em si mesmo. Criticam-se os usos educacionais desse espaço que não valorizam a comunicação, a relação homem-homem, crítica e dialógica. Destacam-se 
a interação e valores essenciais para a vida em sociedade contra a aprendizagem isolada, que estimularia ainda mais o individualismo que marca nossos tempos.

A Educação em rede valoriza a coletividade, a solidariedade, o compromisso, a colaboração. Estar em rede, a partir de uma intencionalidade educativa, pressupõe enxergar e respeitar o outro, aprendendo com ele, ensinando a ele, crescendo juntos.

A tecnologia leva-nos para uma nova cultura; mas ela não precisa ser aos moldes da cultura tecnopólio. Essa é uma escolha social, mas também pessoal. A finalidade de um processo educativo no ciberespaço deveria ser a ampliação de conhecimentos e o aperfeiçoamento de valores morais, e não a redução de custos ou aumento da "eficiência" do ensino.

Entender os princípios que caracterizam a estrutura de rede, que serão vistos neste trabalho, contribui para análise da realidade, "na qual os sujeitos ocupam um espaço significativo de poder, exercendo a sua capacidade de alterar essa realidade, a partir das condições constituídas historicamente" (PRETTO; ASSIS, 2008, p. 77). A partir da Educação.

\section{O início deste trabalho}

No começo, tudo parecia ser o mesmo: rede e comunidade virtual de aprendizagem eram expressões vistas como sinônimas e associadas a ambientes específicos do ciberespaço. Esta pesquisadora navegava pela Internet, desenvolvia projetos educativos em ambientes virtuais sem fazer distinção, como muitos colegas. Esse cenário permaneceu até o ingresso no mestrado da Faculdade de Educação da USP, com um projeto para investigar a participação em comunidades de aprendizagem online.

Como a maioria dos alunos, comecei a procurar referências teóricas que proporcionassem uma reflexão sobre o objeto de estudo, ligado à minha prática profissional. Tinha início uma busca epistemológica de tamanha intensidade que, aos poucos, o projeto inicial foi sendo substituído. A curiosidade transformou concepções e resultou nesta dissertação, diferente da que havia sido planejada.

A mudança iniciou-se com uma pesquisa sobre o significado da palavra "comunidade". Os laços estreitos, a confiança e a colaboração mostraram-se características imanentes que não poderiam ser ignoradas no ciberespaço. $O$ entendimento fez surgir uma série de dúvidas sobre o emprego da palavra "comunidade" para qualquer grupo de pessoas reunidas no ciberespaço. Vimos casos em que "comunidade" designava cursos que sequer 
permitiam interação entre os participantes. Em um dos projetos em que eu atuava, educadores entendiam comunidade virtual de aprendizagem como o ambiente online e não como um grupo de pessoas. Algumas situações começaram a não fazer sentido.

Em meio à literatura sobre comunidades virtuais, foram encontrados textos referentes às redes sociais. Passamos, então, a questionar o emprego mais adequado das duas palavras comunidade e rede -, muitas vezes usadas como sinônimos. "Rede" poderia significar o mesmo que "comunidade", cujos estudos nos levaram à pólis grega? Seria adequado considerar uma comunidade uma rede?

Pessoas que há anos trabalham com Educação online não sabiam nos explicar se havia diferenciação e qual seria. Em um fórum em que se discutiu o que eram comunidades virtuais de aprendizagem, os participantes mostravam não haver clareza entre o que era uma comunidade e uma rede de aprendizagem online. Os "nós" do tecido que se costurava estavam emaranhados, não era possível enxergá-los claramente.

Muito desta busca epistemológica foi motivada pelo poder das palavras. Afinal, "a palavra é fenômeno ideológico por excelência" porque "a realidade toda é absorvida por sua função de signo" (BAKHTIN, 1981, p. 36).

Se nossos pensamentos tomam forma e passam a existir por intermédio dos signos, há de buscar-se o que de fato seriam as palavras que formatam nossa realidade e as relações do dia-a-dia. Foi o que tentamos fazer ao examinar a etimologia e alguns usos sociais dos termos, incomodados por tratarem como sinônimos "rede" e "comunidade virtual de aprendizagem".

Assim, acabei tomada pela necessidade de esclarecer se havia e qual seriam as diferenças. Apaixonada pelo objeto, não percebi que tinha em mãos uma nova pesquisa.

Lembro-me de uma manhã das muitas sextas-feiras em que disse ao meu orientador o quanto estava preocupada porque não conseguia restringir o problema de pesquisa do projeto inicial. Recordo-me de sua serenidade em me dizer que "pesquisar é estudar o que não se sabe" e que pesquisa era o que eu já estava fazendo. Eu tinha um novo objeto, mas ele estava tão entranhado em mim que eu sequer havia percebido.

\section{Problemática e objetivos}

As redes e comunidades virtuais de aprendizagem fazem parte do nosso cotidiano profissional e pessoal. Sabendo-se que a pesquisa científica destina-se - não somente - à 
ampliação dos conhecimentos acerca do que já se conhece, este trabalho apresenta uma reflexão a partir da seguinte problemática:

- Como distinguir as redes e comunidades virtuais de aprendizagem das demais comunidades e redes sociais do ciberespaço?

- De que maneira se pode perceber a formação de uma comunidade virtual em uma situação de aprendizagem em rede?

A busca de respostas para essas questões foi realizada tendo como objetivo geral apresentar uma distinção entre as redes e as comunidades virtuais de aprendizagem em relação aos demais agrupamentos do ciberespaço.

Tal pretensão carrega em si alguns objetivos específicos:

- Realizar uma revisão bibliográfica a respeito do conceito de rede, comunidade, rede social e comunidade virtual de aprendizagem, bem como da origem do ciberespaço a partir de agrupamentos que o construíram.

- Levantar elementos encontrados nas redes e comunidades virtuais de aprendizagem que possam proporcionar uma distinção desses agrupamentos em relação a outros, assim como características que diferenciem as redes de aprendizagem das comunidades de aprendizagem no ciberespaço.

- Examinar circunstâncias em que se desenvolvem as redes e comunidades virtuais de aprendizagem, assim como processos que nelas ocorrem.

- Analisar a formação desses agrupamentos como algo espontâneo ou provocado e qual o papel do professor nesse contexto.

A exposição dos objetivos e da problemática indicaria a complexidade do nosso objeto de pesquisa, que surgiu com o advento da comunicação mediada por computadores. Por ser um fenômeno novo e complexo, esta pesquisa apresenta-se como uma costura realizada com estudos dos campos da Educação, da Comunicação e da Sociologia. A diversidade dos agrupamentos encontrados no ciberespaço só poderia ser analisada a partir de um paradigma que considera essa multiplicidade. $O$ pensamento complexo contribui para que se tente distinguir sem desarticular, associar sem reduzir (MORIN, 2006). 


\section{Metodologia e procedimentos técnicos}

Esta dissertação resulta de um "processo que organiza cientificamente todo o movimento reflexivo, do sujeito ao empírico e deste ao concreto, até a organização de novos conhecimentos, que permitam nova leitura/compreensão/interpretação do empírico inicial" (GHEDIN e FRANCO, 2008, p. 107). Ou seja, de uma concepção de metodologia de pesquisa reflexiva ${ }^{l}$, diferente da que simplesmente organiza a captação de dados empíricos.

Nessa perspectiva, tentamos construir o objeto que pretendíamos conhecer a partir do entendimento de que a construção se desenvolve na inter-relação entre o sujeito e objeto. Segundo Franco (apud GHEDIN e FRANCO, 2008), a relação pode ser interpretada segundo a configuração de, pelo menos, três diferentes modelos teóricos: objetivista, subjetivista e dialético.

Embora não atenda a todas as características apontadas, acreditamos que nossa pesquisa foi realizada a partir do modelo subjetivista, no qual:

[...] A realidade é percebida como criação do sujeito. O objeto do conhecimento é simplesmente a elaboração cognitiva realizada pelo sujeito, sendo desprezada sua dimensão material. Como princípios fundadores desse modelo, pode-se destacar:

- a supremacia do sujeito como objeto do conhecimento;

- a valorização da subjetividade do pesquisador;

- o objeto de conhecimento é aquilo que é significativo ao sujeito;

- o sujeito é o criador da realidade (penso, logo existo);

- o descaso com a importância do objeto do conhecimento;

- a preocupação com processos e condições existenciais;

- o desinteresse pela recuperação histórica dos fenômenos sociais estudados;

- a compreensão dos fenômenos é feita com base na intencionalidade da consciência, na busca de supostas essências que venham a fundamentar o fenômeno;

- $\quad$ ressupõe-se que as pessoas ajam com base em suas crenças, percepções e valores e que todo comportamento tenha um sentido que, para ser compreendido precisa ser desvelado;

- a categoria epistemológica é a interpretação ou a descrição interpretativa;

- parte-se de uma concepção existencialista de ser humano, visto como ser de relações, que elabora sua existência e recebe dela sentido.

A abordagem subjetivista estaria de acordo com o entendimento de que o pesquisador social, por lidar com o humano, não pode ter a ingenuidade de acreditar em objetividade e imparcialidade em suas análises. Essa, inclusive, é uma crítica que Postman (1994, p. 164) faz ao cientismo do tecnopólio, que atribui à pesquisa social a "aura de conhecimento infalível,

\footnotetext{
${ }^{1}$ É como Franco (apud GHEDIN e FRANCO, 2008, p. 107) denomina essa concepção de metodologia, em contraposição a concepção instrumental da metodologia.
} 
que só a ciência pode proporcionar", transformando a própria humanidade em objeto "como as plantas, os planetas e os cubos de gelo".

$\mathrm{Na}$ abordagem subjetivista, o pesquisador é o principal elemento metodológico e entra em contato contínuo com o objeto na busca de dados qualitativos que contribuam para a compreensão do fenômeno.

Como os outros dois modelos teóricos, verifica-se no modelo subjetivista muitos equívocos durante o processo de pesquisa em Educação, como a confusão de subjetividade com subjetivismo, a falta de intersubjetividade e de confronto com o aporte teórico existente.

Cientes da possibilidade de termos cometidos alguns equívocos, tentamos manter, ao longo da investigação, a capacidade de questionar e duvidar. Segundo Ghedin e Franco (2008), o questionamento é fundamental para que se evite produzir conhecimentos já sabidos antes da pesquisa.

Podemos afirmar que nosso estudo não se limita a referendar aquilo que já conhecíamos. Ao iniciar esta investigação, a) não víamos distinção entre as redes e as comunidades virtuais de aprendizagem; b) logo, desconhecíamos os indicadores de formação de uma comunidade virtual de aprendizagem mapeados na investigação; c) não percebíamos os elementos que distinguiam as redes e comunidades virtuais de aprendizagem dos demais agrupamentos do ciberespaço.

Ao iniciar a investigação, esta pesquisadora trabalhava em projetos educativos desenvolvidos na Internet, chamados de comunidades virtuais de aprendizagem naquele contexto. Mas somente após o processo investigativo, passou a conhecer de fato esse objeto, ao qual estava tão perto, mas distante por não refletir a seu respeito.

Para atingir os propósitos a que nos dispusemos, adotamos a observação como procedimento técnico. A observação ajuda a coletar dados para conseguir informações e "provas a respeito de objetivos sobre os quais os indivíduos não têm consciência, mas que orientam seu comportamento". (MARCONI; LAKATOS, 1996, p. 79).

Para Selltiz et al, a observação torna-se uma técnica científica quando:

- convém a um formulado plano de pesquisa;

- é planejada sistematicamente;

- é registrada metodologicamente e está relacionada a proposições mais gerais, ao invés de ser apresentada como uma série de curiosidades interessantes; e

- $\quad$ está sujeita a verificações e controle sobre a validade e segurança. (SELLTIZ et al, 1965, p. 233) 
Entre as vantagens da observação destacadas por Marconi e Lakatos (1996), está a de permitir a evidência de dados que não seriam encontrados por meio de questionários e entrevistas. No entanto, entre as limitações da técnica, a de que os observados tenderiam a criar impressões favoráveis ou desfavoráveis no observador.

Observamos três agrupamentos do ciberespaço, participando de dois deles durante parte da investigação: da lista de discussão "Blogs Educativos" e do curso "Ensinando em Ambientes Virtuais 1". Segundo Marconi e Lakatos (1996), seriam observações "participantes", uma vez que esta pesquisadora se incorporou aos agrupamentos, participando de suas atividades e ficando próxima aos membros. No entanto, em relação ao curso, sentimos necessidade de realizar uma entrevista e aplicar questionários para obtermos informações que não puderam ser observadas. A entrevista é classificada pelos autores como "observação direta intensiva" e o questionário como "observação direta extensiva".

O procedimento investigativo para análise da rede "POIEs do Butantã" também é classificado como observação. Mas, como não inclui a nossa participação, é chamado por Marconi e Lakatos (1996) de "observação sistemática", também conhecida como estruturada, planejada ou controlada. Nela, o observador tem consciência do que procura, destacando na situação o que seria mais importante frente a seus objetivos.

\section{Organização da dissertação}

Esta dissertação inicia-se com um panorama dos conceitos para os quais a investigação se volta, uma amostra do paradigma que norteia as ciências nos dias de hoje: complexo e incerto. Restringimo-nos às relações humanas permeadas pelas Tecnologias de Informação e Comunicação e temos consciência de que novos entendimentos e usos surgem com a mesma rapidez das notícias acerca de inovações tecnológicas. Nosso objeto de estudo, as redes e comunidades virtuais de aprendizagem, seria reflexo e resultado dessa complexidade e instabilidade.

Tínhamos em mente que, no contexto das Tecnologias de Informação e Comunicação, o termo "rede" referia-se à estrutura física que permite a interconexão de computadores, embora pudéssemos empregá-lo por extensão de sentido. A partir desse pressuposto, realizamos uma busca para compreender o que eram as "comunidades virtuais". Fomos atrás da origem do ciberespaço por meio da história da Internet - uma história de comunidades, cujos valores e usos começam a dar forma ao nosso objeto de investigação. 
Buscamos também o conceito de comunidade, que se desdobrou em uma breve reflexão sobre a Pós-Modernidade - também, esta, incerta.

No entanto, nesse caminho, fomos surpreendidos por leituras que não restringiam rede ao aparato físico, relacionando-a às interações humanas, psicológicas e sociais. E, ainda, definindo "redes sociais" da mesma maneira, ou de modo semelhante à expressão "comunidade" no contexto do ciberespaço.

A trajetória levou esta pesquisadora a ingressar na lista de discussão online "Blogs Educativos", conhecida no meio em que atua. Nosso objetivo era identificar se aquele agrupamento seria uma rede social, uma comunidade virtual, uma rede de aprendizagem ou, ainda, uma comunidade de aprendizagem. Para que pudéssemos chegar a um entendimento, considerou-se a experiência de ter participado da lista e a análise de mensagens trocadas entre os participantes, que não foram informados desta investigação - eles apenas souberam que pesquisávamos comunidades virtuais de aprendizagem.

A partir dessa observação, de revisão bibliográfica sobre rede social, comunidade (virtual e não) e dos valores que constituíram o ciberespaço, assumimos que rede social online e comunidade virtual são conceitos distintos.

O CAPÍTULO 1 expõe esse percurso e trata da distinção indicando, no entanto, que não há consenso quanto a esse entendimento, embora rede social e comunidade virtual sejam nós de um mesmo tecido.

No CAPÍTULO 2, entramos no terreno da Educação. É o coração desta dissertação, mas que sem os demais capítulos ficaria sem pulsar. São apontados os elementos que distinguiriam as redes de aprendizagem online das demais do ciberespaço. Eles surgem a partir de revisão bibliográfica, de nossa experiência no desenvolvimento de projetos educativos no ciberespaço e da análise de uma rede de aprendizagem online, a "POIEs do Butantã". Como parte de um todo, o capítulo seguinte também contribuiu para levantarmos esses elementos.

Ainda no capítulo 2, apresentamos um exemplo de concepção de uma rede de aprendizagem online, a partir dos pressupostos que norteiam nossa análise, explorando-os. Além disso, refletimos sobre a dificuldade de interação encontrada em muitas redes de aprendizagem online e, ainda, como a idéia de rede virtual de aprendizagem deste trabalho entrelaça-se com a de cursos online.

No CAPíTULO 3, examinamos a formação de uma comunidade a partir de uma rede de aprendizagem online. A análise das mensagens trocadas entre os participantes, as informações obtidas com a professora e os tutores do curso "Ensinando em Ambientes Virtuais 1 (EAV 1)" 
e a experiência de ter participado como aluna permitiram o mapeamento de indicadores de formação de uma comunidade entre os integrantes.

Por fim, recuperamos os principais nós dessa costura no CAPÍTULO 4, para arrematar a dissertação, sem concluí-la. O objetivo era saber se os propósitos iniciais desta pesquisa foram alcançados e sob quais perspectivas. 


\section{REDE E COMUNIDADE NO CIBERESPAÇO}

1.1. Valores e usos das comunidades que estruturaram a Internet

1.1.2 - A Internet hoje: emaranhado de valores e usos

1.2 Comunidade virtual

1.2.1. Qual Comunidade?

1.2.2. Comunidade na Pós-Modernidade

1.3 Rede

1.3.1 Rede social online

Organização

Estrutura

Dinâmica

Rede x comunidade

1.4 A lista "Blogs Educativos": rede e comunidade virtual

1.4.1 Uma tentativa de distinção

1.5 Redes sociais e comunidades virtuais: iguais e diferentes 


\section{REDE E COMUNIDADE NO CIBERESPAÇO}

Este trabalho tem início pelo lócus que abriga as redes sociais online e comunidades virtuais: o ciberespaço. Voltando à sua origem, foi possível encontrar os grupos que o construíram e seus valores que deram forma ao que hoje se conhece. O recorte apresentado visou destacar a "vocação" que o ciberespaço teria para abrigar redes sociais e comunidades.

Para entender o que seriam as comunidades virtuais, buscamos o conceito da palavra "comunidade" e deparamo-nos com uma diferenciação entre comunidade e rede social no ciberespaço. Uma distinção entre as duas expressões é assumida neste capítulo, que inclui a análise de uma rede social online para também contribuir com esta reflexão.

\subsection{Valores e usos das comunidades que estruturaram a Internet}

A história da Internet ${ }^{2}$ é "uma rara mistura de estratégia militar, grande cooperação científica e inovação contracultural", como resume um dos maiores estudiosos das transformações sociais e econômicas da atualidade, Manuel Castells (1999, vol. 1, p. 375). Entre todos os grandes desenvolvimentos tecnológicos das últimas décadas, a origem da Internet ajuda-nos a compreender em que contexto, com que valores e a partir de quais características estruturais nasce e se desenvolve o nosso objeto de estudo, as redes e comunidades virtuais de aprendizagem. Elas são fruto de um novo paradigma tecnológico que se dissemina a partir da década de 1970, organizado com base na tecnologia da informação.

Surgido em um segmento específico da sociedade norte-americana, o novo paradigma constituiu-se em interação com a economia global e a geopolítica mundial, concretizando "um novo estilo de produção, comunicação, gerenciamento e vida" (CASTELLS, 1999, p. 43). Enfatiza, nos processos tecnológicos, a interatividade, a formação de redes, os dispositivos personalizados e os investimentos e esforços em novas descobertas que, muitas vezes, não têm finalidade comercial. Este paradigma relaciona-se à cultura de liberdade, ao empreendedorismo e à criatividade individual da década anterior, encontrada nos campi dos EUA, principalmente no Vale do Silício (Califórnia).

\footnotetext{
${ }^{2}$ Costa (1999, p. 255) explica que Internet "é o conjunto de meios físicos (linhas digitais de alta capacidade, computadores, roteadores, etc.) e programas (protocolo TCP/IP) usados para o transporte da informação."
} 
"A cultura ${ }^{3}$ da Internet é a cultura dos criadores da Internet", diz Castells (2003, p. 34), que neste capítulo contribui com um panorama dos valores e dos usos sociais subjacentes à estruturação da Internet, fundamentais para entendermos nosso objeto de estudo. O autor explica que a cultura da Internet se caracteriza por uma estrutura em quatro camadas hierarquicamente dispostas: a cultura "tecnomeritocrática", a hacker, a comunitária virtual e a empresarial, que formam a ideologia de liberdade disseminada no mundo da Internet.

[...] a cultura tecnomeritocrática especifica-se como uma cultura hacker ao incorporar normas e costumes a redes de cooperação voltadas para projetos tecnológicos. A cultura comunitária virtual acrescenta uma dimensão social ao compartilhamento tecnológico, fazendo da Internet um meio de interação social seletiva e de integração simbólica. A cultura empresarial trabalha, ao lado da cultura hacker e da cultura comunitária, para difundir práticas da Internet em todos os domínios da sociedade como meio de ganhar dinheiro. Sem a cultura tecnomeritocrática, os hackers não passariam de uma comunidade contracultural específica de geeks e nerds ${ }^{4}$. Sem a cultura hacker, as redes comunitárias na Internet não se distinguiriam de muitas outras comunidades alternativas. Assim como, sem a cultura hacker e os valores comunitários, a cultura empresarial não se pode caracterizar específica à Internet. (CASTELLS, 2003, p. 34).

A Internet que conhecemos é resultado do trabalho de grupos de pesquisadores, de anônimos, de jovens universitários e empresários com objetivos e projetos específicos, espalhados por diferentes locais do planeta, mas principalmente nos Estados Unidos.

A rede mundial de computadores, como também a Internet é conhecida, surgiu a partir de um projeto ambicioso da Agência de Projetos de Pesquisas Avançadas do Departamento de Defesa dos Estados Unidos (ARPA) ${ }^{5}$, que investiu no desenvolvimento de um sistema de comunicação invulnerável a ataque nuclear. O sistema não possuía centro de comando e de controle, de modo que as mensagens percorriam trajetos diferentes e podiam ser recuperadas em qualquer ponto da rede - uma arquitetura que permanece até hoje, tornando muito difíceis a censura e o controle do que nela trafega.

A ARPANET foi a primeira rede desse tipo, criada pelo Departamento de Defesa dos Estados Unidos em 1969, que interligou pesquisadores e centros de computação para o compartilhamento de recursos e troca de mensagens sobre o andamento dos projetos. Como os cientistas a usavam também para conversas científicas e pessoais, uma outra rede foi criada só para aplicações militares, a MILNET.

\footnotetext{
${ }^{3}$ Castells (2001, p. 34) entende cultura como "um conjunto de valores e crenças que formam o comportamento".

4 “Geeks são peritos ou especialistas em computadores; nerds são pessoas exclusivamente voltadas para atividades científicas e, em geral, socialmente ineptas". Nota do tradutor em CASTELLS (2001, p.35).

5 A criação da ARPA foi uma reação aos "sustos" causados pelo lançamento do Sputnik, primeiro satélite artificial da história, pela então União Soviética, em 4 de outubro de1957.
} 
No começo dos anos 80, outras redes foram desenvolvidas pela Fundação Nacional da Ciência: Bitnet, para estudos de matérias não científicas (em parceria com a IBM) e a CSNET, outra rede científica. Mas todas elas usavam a ARPANET como sistema de comunicação que, por isso, passou a ser chamada de ARPAINTERNET, mais tarde apenas INTERNET ${ }^{\mathbf{6}}$, operada pela Fundação e custeada pelo Departamento de Defesa dos EUA.

Enquanto isso, também em 1969, um outro grupo, a Bell Laboratories, desenvolvia um sistema operacional $^{7}$ que possibilitava o acesso de computador para computador. Mas só em 1983 sua utilização foi ampliada quando pesquisadores de Berkeley (com fundos da, novamente, ARPA) adaptaram o $\mathrm{UNIX}^{8}$ ao protocolo ${ }^{9} \mathrm{TCP} / \mathrm{IP}^{10}$, permitindo não apenas a comunicação entre computadores, mas a codificação e decodificação de dados pela Internet.

Os protocolos TCP/IP sobre os quais a ARPANET foi montada eram abertos e gratuitos, assim como o sistema operacional UNIX e outras inovações que se seguiram e deram forma à Internet tal como conhecemos hoje. A abertura e gratuidade são determinadas, em primeiro lugar, pela cultura "tecnomeritocrática" enraizada na academia e na ciência. Trata-se da "crença no bem inerente ao desenvolvimento científico e tecnológico como um elemento decisivo no progresso da humanidade". Sua particularidade, porém, está na "definição de uma comunidade de membros tecnologicamente competentes, reconhecidos como pares pela comunidade." (CASTELLS, 2003, p. 36).

O mérito nessa cultura está na contribuição tecnológica que proporciona um bem comum à comunidade. $\mathrm{O}$ valor supremo é a própria descoberta tecnológica (ligada à programação de computadores em rede), cuja relevância depende da contribuição para o campo como um todo. A importância da descoberta, por sua vez, é determinada pela comunidade, cujos membros são definidos a partir do "desempenho individual tal como avaliado, e publicado, no processo histórico do desenvolvimento da Internet" (CASTELLS, 2003, p. 36).

\footnotetext{
${ }^{6}$ Internet é o "conjunto de todas as redes e gateways que usam protocolos TCP/IP” (CASTELLS, 1999, p. 255)

7 "Um sistema operativo (PE) ou sistema operacional (PB) é um programa ou um conjunto de programas cuja função é servir de interface entre um computador e o usuário.” Disponível em: <http://pt.wikipedia.org/wiki/Sistema_operacional>. Acesso em: 10 fev. 2008.

${ }^{8}$ Unix é um sistema operativo (ou sistema operacional) portátil (ou portável), multitarefa e multiutilizador (ou multiusuário) originalmente criado por Ken Thompson, que trabalhava nos Laboratórios Bell (Bell Labs) da AT\&T. A marca UNIX é uma propriedade do "The Open Group", um consórcio formados por empresas de informática. Disponível em: <http://pt.wikipedia.org/wiki/Unix>. Acesso em: 10 fev. 2008.

9 "Protocolo na informática é o termo usado para um conjunto de informações ou dados que passam por um preparo para serem repassados a outros programas." Disponível em: 〈http://pt.wikipedia.org/wiki/Protocolo>. Acesso em 10 fev. 2008

${ }^{10} \mathrm{TCP} / \mathrm{IP}$ é um conjunto de protocolos de comunicação entre computadores em rede. Seu nome vem dos dois protocolos mais importantes do conjunto: o TCP (Transmission Control Protocol - Protocolo de Controle de Transmissão) e o IP (Internet Protocol - Protocolo de Interconexão). Disponível em: <http://pt.wikipedia.org/wiki/TCP/IP>. Acesso em 10 fev. 2008.
} 
Nessa comunidade, há autoridades que coordenam as tarefas e os projetos controlam os recursos e contam com o respeito e a confiança ética dos demais integrantes características que, veremos, também aparecem nas redes e comunidades virtuais de aprendizagem. O respeito aos membros da comunidade demanda de seu comportamento, que deve estar de acordo com normas formais e informais da comunidade e "não usar recursos comuns (conhecimento) ou recursos delegados (posições institucionais) para seu benefício exclusivo" (CATELLS, 2003, p. 37), partilhando os avanços tecnológicos entre os demais. Segundo Castells, de todas as características da cultura "tecnomeritocrática", a pedra angular foi a comunicação aberta do software, sem a qual a competitividade individual sobreporia o esforço cooperativo.

As bases da Internet foram criadas por essa cultura advinda da ciência institucionalizada. Mas “paralelamente aos esforços do Pentágono e da 'Grande Ciência' para estabelecer uma rede universal de computadores com acesso público dentro das "normas aceitáveis', uma contracultura computacional sempre crescente surgia nos EUA" (CASTELLS, 1999, vol. 1, p. 377).

Os hackers são os atores que aparecem na transição de um ambiente institucionalmente construído para um que escapa do controle organizacional: o das redes auto-organizadas, responsáveis pela atualização tecnológica a partir da cultura anterior.

A cultura hacker diz respeito ao "conjunto de valores e crenças que emergiu das redes de programadores de computador que interagiam online em torno de sua colaboração em projetos autonomamente definidos de programação criativa" (CASTELLS, 2003, p. 38). Ela opera como eixo na construção da Internet, segundo o autor, por duas razões: torna-se o ambiente fomentador de inovações tecnológicas capitais mediante a comunicação livre e a cooperação; é a ligação entre o conhecimento que emergiu da cultura "tecnomeritocrática" e os subprodutos comerciais que levam a Internet à sociedade em geral.

O "código-fonte" da cultura hacker é a cultura "tecnomeritocrática", ou seja, as características da cultura anterior permanecem. Mas a busca da excelência tecnológica desvinculada de instituições compensatórias "requer a adesão a um conjunto de valores que combinam a alegria da criatividade com a reputação entre os pares" (CASTELLS, 2003, p. 42).

Nesse conjunto, a liberdade é o valor supremo: para criar, para apropriar todo o conhecimento disponível e redistribuí-lo sob qualquer forma ou canal escolhido pelo hacker. Mas nem todas as pessoas desse grupo têm a liberdade como único valor: a inovação tecnológica e o prazer que advêm da criatividade seriam ainda mais importantes. 
Paradoxalmente, em nome da liberdade, muitos hackers reivindicam o direito de comercializar suas aplicações, mantendo, no entanto, acesso aberto ao programa e permissão para que seja modificado.

"A liberdade combina-se com a cooperação através da prática da cultura do dom, que acaba por levar a uma economia do dom" (CASTELLS, 2003, p. 42), uma vez que estas pessoas divulgam sua contribuição esperando reciprocidade. Mas essa cultura do dom se distingue de outras semelhantes: prestígio, reputação e estima social ligam-se à doação feita à comunidade. Não se trata de pura generosidade, mas de satisfação em exibir a descoberta, além da gratificação envolvida no próprio objeto. E, assim, o valor não está apenas na troca, mas também no uso de um produto inovador.

O ímpeto pessoal de criar e a alegria dessa ação também aparecem na cultura hacker, independente do cenário institucional a que ele está ligado, já que muitos trabalhavam em empresas e centros de pesquisa, criando dentro e fora deles. Os hackers "não dependem de instituições para sua existência intelectual, mas dependem, efetivamente, de sua comunidade autodefinida, construída em torno de redes de computadores" (CASTELLS, 2003, p. 43).

O sentimento comunitário advém de uma organização social informal. Podemos encontrar comunidades, como a Linux, que possuem uma autoridade, no caso "Linus Torvalds" que criou o sistema operacional GNU/Linux, em torno da qual seus integrantes se reúnem. Em outras comunidades, a autoridade pode ser coletiva e com rotação de mantenedores, como na comunidade dos servidores Apache.

Alicerçada na Internet, a cultura hacker é, em geral, global, informal e virtual. As pessoas se conhecem pelo nome que usam, raramente se encontram no mesmo espaço físico e as divisões fundamentais não são pessoais ou ideológicas, mas tecnológicas. Há, no entanto, subculturas hackers construídas sobre princípios políticos e revolta pessoal, explica Castells (2003). Richard Stallman fundou a "Free Software Foundation" para defender o princípio do software gratuito, mantendo-o fora do alcance de governos e corporações. John Perry Barlow e Mitch Kapor criaram a "Eletronic Frontier Foundation" para combater o controle sobre a Internet.

A diversidade na cultura hacker inclui, ainda, os crackers: pessoas que tentam provar sua perícia, misturam a habilidade técnica com estratégias de sabotagem política para vigiar quem os vigia e/ou formam redes cooperativas para difundir códigos de criptografia que permitiriam a formação de redes fora dos olhos das agências de vigilância. Apesar dos diferentes comportamentos pessoais, hackers e crackers têm em comum a crença na interconexão de computadores e os esforços para mantê-la como um bem comum. 
No entanto, as fontes culturais da Internet não advêm apenas dos valores daqueles que inovaram tecnologicamente. Rheingold (1996) e os primeiros usuários de redes de computadores agregaram-se em comunidades virtuais, desenvolvendo e difundindo valores e formas de usos que estruturaram a Internet e ainda hoje permanecem.

Segundo Castells, as comunidades online tiveram origens muito semelhantes às dos movimentos contraculturais e dos modos de vida alternativos da década de 1960. Entre os administradores, hospedeiros e patrocinadores de uma das primeiras comunidades virtuais, a WELL, por exemplo, "estavam pessoas que haviam tentado a vida em comunidades rurais, hackers de computadores pessoais, e um grande contingente de deadheads, fãs da banda de rock Grateful Dead" (2003, p. 48).

Mas as conexões com a contracultura enfraqueciam à medida que as comunidades online se multiplicavam. Castells, assim como Rheingold, não acreditam em uma cultura comunitária unificada nos dias atuais, como a hacker. A diversidade de valores e normas sociais das comunidades são tão diversas quanto na própria sociedade. Apesar disto, Castells (2003) identifica dois grandes valores em torno dos quais as comunidades virtuais trabalham: a comunicação livre, horizontal, ligada à prática da livre expressão global advinda do início da criação da Internet; e o valor compartilhado a que o autor chama da "formação autônoma das redes", ou seja, qualquer pessoa pode formar um agrupamento e divulgar sua própria informação. Voltaremos a tratar das comunidades virtuais, objeto desta investigação, mais adiante.

Por fim, a cultura empresarial é a última apontada nesta estruturação hierárquica da Internet. Foram os empresários que levaram a rede mundial de computadores para além dos cientistas e militares, hackers e demais pessoas organizadas em comunidades virtuais. "Só aconteceu na década de 90, com a velocidade de um raio" (2003, p. 29), o suficiente para incorporar à rede usos comerciais. "Mas como estes tiveram por base formas e processos inventados pela cultura comunitária, os hackers e as elites tecnológicas, o resultado real é que a Internet não é mais determinada pelos negócios que outros domínios da vida em nossa sociedade. Nem mais, nem menos também" (2003, p.49).

Para Castells, os valores supremos dessa cultura são a soma de dinheiro a ganhar e a velocidade em que isso ocorre - o que vai além da cobiça humana usual. Valores de pessoas que sonhavam e criavam novos produtos e processos que dessem muito dinheiro a si mesmas, em um mundo que não tinham imaginado, nem inventado. Diferentemente da cultura "tecnomeritocrática" e hacker, para elas, a liberdade e o reconhecimento entre os pares eram atrelados ao capital que podiam ganhar. 
Trata-se de uma cultura do dinheiro e do trabalho compulsivo e incessante. O que, na maioria das vezes, resulta em solidão, já que esses empresários sacrificam a vida pessoal pela pressa em fazer capital e ter poder a partir de idéias. "O individualismo é a regra: assim, deixados sozinhos consigo mesmos, os empresários usam sua dose extra de adrenalina para acelerar seu impulso de destruição criativa, que acaba por levar à criação destrutiva" (CATELLS, 2003, p. 52), de suas vidas sociais e pessoais.

Essas características culturais jamais poderiam ter criado um mundo baseado na interconexão e na comunicação, diz o autor. "Mas sua contribuição foi/é indispensável à dinâmica cultural de múltiplas camadas geradas pelo mundo da Internet" (CASTELLS, 2003, p. 53).

\subsubsection{A Internet hoje: emaranhado de valores e usos}

A Internet reflete os valores daqueles que a construíram, usam e a modificam, a partir da compreensão de que valor "refere-se àquilo de que a pessoa gosta e que valoriza" (ARAÚJO, 2007, p.21). Afinal, tal como viver em sociedade, não seria possível dissociar ações e valores e, assim, o mundo virtual torna-se espelho do "real". Os tecelões da rede mundial de computadores compartilhavam a liberdade de comunicação e criação, a cooperação, o prestígio, o reconhecimento e a interconexão. Mas outros valores que prejudicam os internautas também são encontrados no ciberespaço.

As comunidades virtuais, por exemplo, podem potencializar suicídios, incentivar a anorexia, o racismo, disseminar a pedofilia e outros crimes, como destacado em reportagem da revista Galileu (TIRABOSCHI, 2008). "Antes da Internet era mais difícil para suicidas potenciais encontrarem uns aos outros, mais difícil ainda para indivíduos desenvolverem 'culturas suicidas' nas quais uns encorajam os outros a se matarem", diz Will Reader, professor de psicologia da Universidade de Sheffield Halam (Reino Unido) no trecho da reportagem sobre dois jovens (um brasileiro) que cometeram suicídios incentivados por "amigos", ou seja, pessoas que se beneficiam do anonimato, da facilidade de encontrar internautas com interesses comuns aos deles e do alto grau de interação das redes online. As comunidades virtuais “[...] Aumentam exponencialmente os efeitos benéficos dessas redes, mas em compensação explodem de usos condenáveis", ressalta o psiquiatra Benilton Bezerra Junior, na mesma reportagem. 
Em uma reportagem (NETTO, 2007) que encontramos na Web, - uma das funções da Internet mais utilizadas nos dias atuais - o belga Robert Cailliau que, junto com o inglês Tim Berners-Lee, criou a World Wide Web (WWW ou simplesmente Web) ${ }^{11}$, critica o uso excessivamente comercial da rede mundial de computadores. Paradoxalmente, a própria Web, inventada por eles em 1993 como uma ferramenta para pesquisadores, foi a responsável por chamar a atenção do comércio e das empresas de telecomunicação quanto aos potenciais da rede, que, naquela época, já tinha 25 anos.

Apesar de valorizar os espaços em que as pessoas podem compartilhar (Wikipedia ${ }^{12}$, $b \log s^{13}$ ), Caillau (NETTO, 2007) critica as empresas e produtos que concentram informações da vida privada de seus usuários e desviam o foco da realidade e dos problemas sociais e econômicos. $\mathrm{O}$ inventor decepciona-se com a lentidão em se compreender que a rede mundial é uma construção coletiva.

"Empresários, políticos e freqüentemente jornalistas não compreendem isso. Nós poderíamos avançar mais rápido se tivéssemos colaborado mais em vez de promover a competição em um tema no qual a competição é muitas vezes nefasta" (NETTO, 2007). Mas, por outro lado, diz o Caillau, a Web "não se deixa manipular demais: a democracia parece estar imbricada na rede mundial. É isto que, aliás, irrita os espertos que querem se apropriar dela e também os ditadores e os chefes de regimes opressivos" (NETTO, 2007).

Rheingold (1996), um dos pioneiros das comunidades virtuais, também nos ajuda a pensar na complexidade de valores e usos da Internet. $\mathrm{O}$ autor enfatiza a possibilidade aberta pela Internet de uma comunicação de "muitos para muitos", que permitiria a criação de novos espaços públicos, constituindo-se em uma alternativa para o poder hierárquico dos media comerciais. O ciberespaço, como se refere, pode estimular o convívio e a compreensão entre pessoas, auxiliando na revitalização da esfera pública. "A visão de uma rede de telecomunicações delineada e controlada pelos cidadãos do mundo é uma versão da utopia tecnológica que pode ser apelidada de visão da ágora eletrônica" (RHEINGOLD, 1996, p.

\footnotetext{
11 “A World Wide Web é uma função da Internet que junta, em um único e imenso hipertexto ou hiperdocumento (compreendendo imagens e sons), todos os documentos e hipertextos que a alimentam." (Lévy, 1999, p. 27)

${ }^{12}$ A Wikipédia é "uma enciclopédia escrita em colaboração pelos seus leitores. Este sítio utiliza a ferramenta Wiki, que permite a qualquer pessoa, inclusive a você, melhorar de imediato qualquer artigo clicando em editar no menu superior de cada página." Disponível em: 〈http://pt.wikipedia.org/wiki/Wikipedia:Boas-vindas〉. Acesso em 10 fev. 2008

13 “Um weblog, blog ou blogue é uma página da Web cujas atualizações (chamadas posts) são organizadas cronologicamente de forma inversa (como um diário). Estes posts podem ou não pertencer ao mesmo gênero de escrita, referir-se ao mesmo assunto ou ter sido escritos pela mesma pessoa." Disponível em: < http://pt.wikipedia.org/wiki/Blog>. Acesso em 10 fev. 2008.
} 
28). A ágora, na Atenas democrática, era um local onde os cidadãos se encontravam para conversar, "contar mexericos", discutir política, etc.

No entanto, há riscos nas oportunidades abertas pelo ciberespaço. Rheingold destaca a crítica feita por Foucault ${ }^{14}$ de que a rede de telecomunicações mundial se constituiria em um gênero camuflado de Panóptico ${ }^{15}$ e, assim, "os cidadãos de todo o mundo trariam para dentro de casa os ouvidos inquiridores do Estado" (FOUCAULT, 1996, p. 28) e transmitiriam para fora dela informações a interessados.

Os efeitos da interconexão que a Internet proporciona entre as pessoas também se mostram complexos. Algumas pesquisas indicam que a Internet pode conduzir ao isolamento social, afastando os internautas do convívio com a família e amigos em ambientes "reais", já que prefeririam se relacionar aleatoriamente com pessoas desconhecidas e, muitas vezes, sem identidade, na rede.

Outras investigações, como de Cole et. al (apud CASTELLS, 2003), revelaram que o uso do e-mail e das salas de chat tinham um impacto positivo na capacidade dos internautas pesquisados de fazer amigos e se comunicar com os familiares. Wellman e equipe (2000 apud CASTELLS, 2003), após entrevistar 40 mil usuários na América do Norte, constataram que o uso do e-mail - principal ferramenta usada na Internet - contribuía para a interação face a face, por telefone e por carta, sem substituir outros tipos de interação social.

Estes novos padrões de interação social, contradições e valores que, muitas vezes, não estão alinhados com as culturas originais na Internet, também contribuem para observarmos nosso objeto de pesquisa. No entanto, nosso principal objetivo até aqui foi recuperar a criação da Internet por meio das comunidades instituidoras e seus valores. Ao focar as culturas que estruturaram a rede de computadores, Castells $(1999,2003)$ ajudou-nos a enxergar os usos e valores iniciais que até hoje norteiam o comportamento na Internet. Também nos mostrou que sua história é, fundamentalmente, uma história de comunidades.

Mas, para entendermos o que são as comunidades virtuais de aprendizagem, também percorremos outras rotas. A próxima expõe nossa busca por comprender mais profundamente esses agrupamentos, ainda sem entrarmos no terreno da Educação.

\footnotetext{
${ }^{14}$ FOUCAUlT, Michel. Discipline and Punish: The Birth of the prision. Nova Iorque: Random House, 1979.

15 "Panóptico era o nome da prisão perfeita, proposta seriamente no século XVIII pelo inglês Jeremy Bentham. A idéia de Bentham combina a arquitetura e a óptica de forma a permitir que um único guarda observe todos os prisioneiros, impossibilitando-os de verem seja o que for e fazendo-os agir como estando permanentemente sob vigilância” (RHEINGOLD, 1996, p. 29).
} 


\subsection{Comunidade virtual}

As comunidades virtuais surgiram há cerca de 30 anos, mas só nos últimos anos a cultura de colaboração online começou a se expandir. Rheingold (1996) compara as comunidades virtuais do ciberespaço a colônias de microorganismos diversos que por ele se alastram.

O Usenet, primeiro grande fórum online, é um dos principais exemplos de comunidade virtual de grande abrangência, surgida em 1979. Rheingold (1996) e Castells (1999) também conferem destaque aos Sistemas de Boletins Informativos (BBS) ${ }^{16}$, que, em 1989, foram usados por estudantes chineses para protestar contra os acontecimentos da Praça da Paz Celestial, em uma grande manifestação do potencial dos novos dispositivos de comunicação.

A intersecção entre essas diferentes comunidades está no fato de seus membros se corresponderem no ciberespaço, expressão que passaremos a adotar a partir deste ponto. Ciberespaço designa um espaço para além da Internet, como Rheigold (1996, p. 18) explica: "o espaço conceptual onde se manifestam palavras, relações humanas, dados, riquezas e poder da tecnologia de CMC” (Comunicação Mediada por Computadores).

A palavra "ciberespaço" foi inventada em 1984 por William Gibson para seu romance de ficção científica Neuromancer e espalhou-se por usuários e criadores de redes digitais. Lévy (1999) é outro autor que adota a expressão, entendendo-a como:

[...] o espaço de comunicação aberto pela interconexão mundial dos computadores e das memórias dos computadores. Essa definição inclui o conjunto de sistemas de comunicação eletrônicos (aí incluídos os conjuntos de redes hertzianas e telefônicas clássicas), na medida em que transmitem informações provenientes de fontes digitais ou destinadas à digitalização. Insisto na codificação digital, pois ela condiciona o caráter plástico, fluido, calculável com precisão e tratável em tempo real, hipertextual, interativo e, resumindo, virtual da informação que é, parece-me, a marca distintiva do ciberespaço. (LÉVY, 1999, p. 92).

Ciberespaço possui diversas definições que variam de acordo com os autores. $\mathrm{O}$ mesmo acontece com a expressão comunidades virtuais, que passamos a explorar.

\footnotetext{
16 "Os sistemas de boletins informativos não precisavam de redes de computadores sofisticadas; apenas PCs, modems e linha telefônica. Por isso tornaram-se o quadro de avisos eletrônicos de todos os tipos de interesses e afinidades". (CASTELLS, 1999, p. 378)
} 
Após revisão bibliográfica sobre o conceito de comunidade, que inclui autores como Durkheim, Tönnies, Shumar e Renninger, entre outros, Rodríguez Illera (2007) ${ }^{17}$ afirma:

\begin{abstract}
As comunidades, virtuais ou não, são sempre organizações temporais, coesas, mas multi-nível, tanto pelos interesses individuais (o tema em torno do qual gira a comunidade), como pelo enquadramento institucional e social em que ocorrem. Em qualquer caso, tudo depende de considerarmos que uma comunidade é uma entidade que pode ser descrita, com características reconhecíveis e em que o seu aspecto estrutural é determinante, ou, então, como uma entidade com valor fundamentalmente simbólico, de estabelecimento de limites, e por isso intencional, devendo ser descrita também a partir de dentro da experiência dos seus participantes. (RODRÍGUEZ ILLERA, 2007, p. 118, grifo nosso).
\end{abstract}

A definição acima pode ser atribuída tanto às comunidades do ciberespaço como às geograficamente encontradas - digamos assim -, o que revela a dificuldade em conceituá-las. Rheingold (1996, p.18), por exemplo, refere-se às comunidades virtuais como "agregados sociais surgidos na Rede, quando os intervenientes de um debate o levam por diante em número e sentimento suficientes para formarem teias de relações pessoais no ciberespaço", definição que muito se assemelha ao que vimos em relação às redes sociais.

Beltrán Llera ${ }^{18}$ (2007) define, em linhas gerais, as comunidades virtuais como "grupos de pessoas que se comunicam, compartilham experiências e temas afins e se esforçam para atingir objetivos comuns".

Para Lévy (1999, p. 27), uma comunidade virtual "é um grupo de pessoas se correspondendo mutuamente por meio de computadores interconectados" que se constrói sobre "afinidades de interesses, de conhecimentos, sobre projetos mútuos, por meio de cooperação ou de troca, independentemente das proximidades geográficas e das filiações institucionais." (1999, p. 127)

Ainda que Rheingold circunscreva comunidades virtuais como às que se situam no ciberespaço, a diferença entre elas e as encontradas geograficamente não nos parece muito explícita. Beltrán Llera (2007), como outros autores pesquisados, não citam o ciberespaço diretamente.

Já Lévy contribui para um melhor entendimento quando explica que "apenas as particularidades técnicas do ciberespaço permitem que os membros de um grupo [...] se

\footnotetext{
${ }^{17}$ Professor titular da Faculdade de Pedagogia da Universidade de Barcelona, coordenador do programa de doutoramento em Multimedia Educativo e do grupo de investigação Ensino e Aprendizagem Virtuais. O perfil completo pode ser consultado em <http://www.ub.es/the/professorat/cv\%20prof/JLRI.htm>, acesso em 25 out. 2007.

${ }^{18}$ Catedrático de Psicologia Evolutiva e da Educação na Universidade Complutense de Madri e presidente da Sociedade Espanhola de Psicopedagogia. Para melhor compreensão, as citações neste trabalho estão em Português e foram traduzidas do original por Gissela Mate, a nosso pedido.
} 
coordenem, cooperem, alimentem e consultem uma memória comum, e isto quase em tempo real, apesar da distribuição geográfica e da diferença de horários” (1999, p. 49, grifo nosso).

Como a citação acima indica, a memória seria um dos fatores mais importantes em uma comunidade virtual, uma vez que a identidade do grupo tem estreita relação com sua memória coletiva. Para Lévy, a construção, o armazenamento e o acesso à memória distinguiriam as comunidades virtuais das "comunidades do passado".

\begin{abstract}
Hoje, acho que uma comunidade precisa organizar-se em torno de uma memória comum, e uma das funções principais de cada membro de uma comunidade da Era Cibernética é participar para ajudar o crescimento de uma memória comum e preencher com a fonte de memória. Dou e retiro algo desta memória comum, e nós todos estamos fazendo isso. De certa forma, todos estamos cultivando este valor comum. A comunidade é o círculo, e no centro há a memória comum, o conhecimento comum e cada um de nós está cultivando o que é comum a nós. Você dá e você retira. E quanto mais você dá, e quanto mais as pessoas dão, melhor é a qualidade do conhecimento que você retira de volta. Então essa é a nova regra, digamos. (IDÉIAS DO FILÓSOFO DO CIBERESPAÇO, 2007, grifo nosso)
\end{abstract}

Lévy acredita que, como os movimentos sociais, as comunidades virtuais precisam de um sentimento compartilhado, pois trata-se de uma criação cultural, social. Naturalmente, os que vivem em uma sociedade que conta com um suporte técnico como o ciberespaço lá acabam criando novas formas de organização. O ciberespaço teria o poder de realizar uma "atualização" das pessoas, potencializando o seu agrupamento e, assim, o surgimento de comunidades. A esse entendimento chegamos após buscar o significado da palavra virtual ${ }^{19}$ que compõe a expressão que tanto queremos compreender.

Quando pensamos em virtual, inseridos em um contexto que nos remete ao ciberespaço, lembramos das informações sob código binário, pensamos em digital. Mas fora desse contexto, geralmente o que nos vem à mente é o significado corrente de "irreal", uma oposição ao que seria a realidade concreta. Longe de sê-lo, o virtual pode ser entendido numa acepção filosófica, em que significa uma atualização do real, o que pode vir a ser. Lévy explica que o virtual seria uma dimensão da realidade, o que existe em potência e não em ato: uma semente que contém potencialmente uma árvore, por exemplo.

Assim, o virtual não se opõe ao real, mas ao atual. Daí a importância das comunidades virtuais: "elas realizam de fato uma verdadeira atualização (...) dos grupos humanos que eram apenas potenciais antes do surgimento do ciberespaço" (LÉVY, 1999, p.130). O mais sensato,

\footnotetext{
${ }^{19}$ A etimologia nos leva ao latim "virtualis", "virtus", este significando "força corporal, ânimo, denodo, ferocidade, força de espírito, virtude, amor e prática do bem, poder de eloqüência, castidade (de mulher)"; 1789 é a data para a acepção "equivalente a outro" (HOUAISS, 2002).
} 
então, seria referirmo-nos a "comunidades atuais", mas empregaremos a expressão comunidades virtuais porque é a que se utiliza no dia-a-dia.

Castells (1999) também contribui para a nossa compreensão ao explicar, com base em estudos de linguagem, que a percepção da realidade seria, de fato, realizada de maneira virtual. Não haveria separação entre realidade e representação simbólica à medida que as culturas são formadas por processos de comunicação. A realidade seria sempre virtual por ser percebida por intermédio de símbolos no processo de interação.

Portanto, o que é historicamente específico no novo sistema de comunicação organizado pela integração eletrônica de todos os meios de comunicação, do tipográfico ao sensorial, não é a indução à realidade virtual, mas a construção da virtualidade real. [...] É um sistema em que a própria realidade (ou seja, a experiência simbólica/material das pessoas) é inteiramente captada, totalmente imersa em uma composição de imagens virtuais no mundo do faz-de-conta, no qual as aparências não apenas se encontram na tela comunicadora da experiência, mas se transformam na experiência. (CASTELLS, 1999, p. 395, grifo nosso).

O meio passa a absorver a experiência humana e, assim, constitui-se como um terreno fértil para o surgimento de comunidades "reais". Tendo acompanhado a emergência dessas comunidades, Rheingold percebeu que onde a tecnologia da CMC se torna acessível surgem agregados virtuais, "tal como microorganismos inevitavelmente se constituem em colônias" (1996, p. 19). O autor suspeita que a explicação para esse fenômeno seja o desejo dos indivíduos de viver em comunidade, ao passo em que cada vez mais desaparecem espaços públicos para sua constituição. Além disso, a tecnologia permitir-lhes-ia interagir de forma inovadora.

Novas relações pessoais se constituiriam no ciberespaço por meio das comunidades virtuais, constituindo padrões que são estudados por diversos pesquisadores. De modo geral, tais relações se desenvolvem a partir da troca contínua de mensagens entre os participantes, cujo fluxo seria mantido em consonância com os interesses e motivações dos integrantes, na maioria das vezes, de maneira não-sistemática.

Ainda que não haja um padrão definido para explicar a dinâmica das comunidades virtuais do ciberespaço, Beltrán Llera (2007) identifica alguns traços comuns: são comunidades flexíveis tanto do ponto de vista temporal quanto do espacial; há intercâmbio de informação; seus membros compartilham linguagens e interesses afins; a comunicação se estabelece com o uso de diferentes instrumentos tecnológicos: correio eletrônico, bate-papo etc.; é uma comunicação multidirecional e mais regular que a do cara-a-cara. 
Sem elementos não-verbais da comunicação face a face, que contribuem para o significado de uma mensagem, o valor simbólico do pertencimento a uma comunidade acaba por ser reforçado, segundo Rodríguez Illera (2007). Como a comunicação é principalmente baseada na linguagem escrita, em geral, os limites que definem uma comunidade são sempre explícitos. "A escrita e o registro permanente das interações anularam a dupla visão, externa e interna, emic e etic, que se poderia ter ao observar uma comunidade, pois tudo nas comunidades virtuais é exterioridade e falta de complexidade na definição das fronteiras" (RODRÍGUEZ ILLERA, 2007, p. 119).

Um dos motivos que levaria uma pessoa a participar de uma comunidade virtual seria, além dos interesses que agrupam os membros do grupo, o mesmo de pertencer a uma comunidade não-virtual. Referimo-nos aos sentimentos "bons" impregnados à palavra: segurança, prazer, tranqüilidade, ausência de estranhos... O ciberespaço também atrairia homens e mulheres que "procuram por grupos a que poderiam pertencer, com certeza e para sempre, num mundo em que tudo se move e se desloca, em que nada é certo", como escreveu Hobsbawn (apud BAUMAN, 2003).

\subsubsection{Qual comunidade?}

A Internet pode ser vista como uma rede desenvolvida por comunidades de cientistas, de militares, de hackers, empresários e pessoas anônimas interessadas em comunicação via computadores e que foram integrando a grande teia que confeccionaram. Algumas dessas comunidades reuniam-se presencialmente, outras a distância - grupo que mais particularmente nos interessa. Mas podemos definir comunidades virtuais apenas como as que se reúnem no ciberespaço?

Questionando-nos, vimos que para poder compreender o que seriam as comunidades virtuais, precisávamos tentar entender o que são comunidades. Para nossa surpresa, tal conceituação mostrou-se mais complexa e divergente do que as definições que encontramos sobre comunidade virtual - mesmo porque essa é objeto recente de estudos, ao contrário da outra.

A definição de comunidade remete-nos aos gregos dos séculos VII e VI e a Atenas entre os séculos V e IV, antes de Cristo, que criaram a polis como uma comunidade: o lugar onde o homem era ele mesmo (KALINA; KOVADLOFF, 1987). Para os gregos, a polis era 
mais do que o espaço do trabalho, era o campo do diálogo, do encontro interpessoal, das celebrações.

A esfera da polis era política e se constituía por uma vida entre pares. Mas o conceito de igualdade, na época, em nada tem a ver com o conceito dos dias atuais - que veremos adiante - por pressupor a existência de desigualdade fora da polis. Mas era a igualdade, segundo Arendt (2005), o elemento diferenciador da esfera familiar, onde reinava a desigualdade pelo poder do chefe da família. Fazer parte da polis era ser livre, justamente pela convivência entre iguais. "Ser livre significava ao mesmo tempo não estar sujeito às necessidades da vida nem ao comando do outro e também não comandar" (2005, p. 41). A igualdade era, assim, a essência da liberdade e nada tem a ver com a justiça, como nos tempos pós-modernos.

A esfera familiar, pelo contrário, era o espaço da desigualdade e, portanto, da falta de liberdade. Seus membros estavam ligados pela sobrevivência, pela própria vida, cuja manutenção requer a companhia de outros. O labor do homem supria os alimentos e o da mulher, a evolução da espécie, naturalmente. O que unia aquela comunidade era a necessidade, que vale tanto para o animal humano quanto para outras formas de vida animal (ARENDT, 2005).

O pensamento grego via essa associação natural como diretamente oposta à capacidade de organização política da polis. "O surgimento da cidade-estado significava que o homem recebera, 'além da sua vida privada, uma espécie de segunda vida, o seu bios politikos. Agora cada cidadão pertence a duas ordens de existência; e há uma diferença entre aquilo que lhe é próprio (idion) e o que é comum (koinon)'” (JAEGER apud ARENDT, 2005, p. 33).

Aristóteles (apud ARENDT, 2005) considerava duas atividades (bios politikos) políticas entre as demais atividades na comunidade: a ação (práxis) e o discurso (lexis). Segundo Arendt, é possível que esstas duas ações políticas tenham surgido antes da polis, e, embora da cidade-estado tenha permitido ao homem viver em ação e discurso, essas atividades tornavam-se cada vez mais independentes da polis.

Com o passar do tempo, o discurso ganhava mais ênfase do que a ação e se tornava persuasão, que era uma forma de distinção do ordenar familiar - visto como uma violência - e a principal caracterização do ser político, que tudo decidia por meio de palavras e persuasão. Estar fora da polis era ser excluído "não da faculdade de falar, mas de um modo de vida no qual o discurso tinha sentido e no qual a preocupação central de todos os cidadãos era discorrer uns dos outros" (2005, p. 36). 
A rigor, a polis não é a cidade-estado em sua localização física; é a organização da comunidade que resulta do agir e falar em conjunto, e seu verdadeiro espaço situa-se entre as pessoas que vivem juntas com tal propósito, não importa onde estejam. "Onde quer que vás, serás uma polis": estas famosas palavras não só vieram a ser a senha da colonização grega, mas exprimiam a convicção de que a ação e o discurso criam entre as partes um espaço capaz de situar-se adequadamente em qualquer tempo e lugar. Trata-se do espaço da aparência, no mais amplo sentido da apalavra, ou seja, o espaço no qual eu apareço aos outros e os outros a mim; onde os homens assumem uma aparência explícita, ao invés de se contentar em existir meramente como coisas vivas ou inanimadas. (ARENDT, 2005, p. 211, grifo nosso).

Ao longo dos séculos, o sentido de comunidade que se refere a polis se transforma, mas "a identidade, o sentimento de nós e o interesse coletivo" (SOUZA, 1987, p. 60) podem ser encontrados em algumas concepções de comunidades que apareceram no século $\mathrm{XX}$, embora, por conta dos condicionamentos sócio-históricos das sociedades que alteraram o contexto urbano e rural, tornou-se "complexa uma definição objetiva de comunidade" (p. 61).

Newstetter (apud FERREIRA, 1968, p. 2.), por exemplo, define comunidade "como dois ou mais grupos numa relação de interação psíquica (...)”. Para Rios (apud FERREIRA, p. 18), trata-se de "um grupo humano vivendo em área geográfica contígua, caracterizado por uma trama de relações e contatos íntimos, possuindo a mesma tradição e os mesmos interesses, mais a consciência de participação em idéias e valores comuns”. Lindeman (apud SOUZA, 1987), embora considere uma comunidade como associação de grupos, acredita que muito raramente ela aja como um todo.

No dia-a-dia, a palavra "comunidade" ganha conotações diversas como: sinônimo de sociedade, categoria de pessoas (comunidade evangélica), referência política (Comunidade Econômica Européia), adjetivo de social (ação comunitária), etc. Para, Hobsbawn (1995) a palavra "comunidade" nunca foi utilizada de forma tão indiscriminada e vazia.

Hobsbawn é um dos autores citados por Bauman (2003) para uma reflexão quanto à convivência em comunidade em tempos de globalização. De imediato, o livro de Bauman, que tem o sugestivo nome "Comunidade: a busca por segurança no mundo atual", chama atenção para uma análise quanto à "sensação" impregnada à palavra que o intitula. Comunidade reportaria-nos a algo bom, prazeroso, que transmite tranqüilidade, conforto e, principalmente, segurança.

A maioria de nós acreditaria que seria muito bom fazer parte de uma comunidade, mas nem sempre o mesmo é dito em relação à palavra "sociedade" porque a ela não estaria associada às mesmas sensações. Afinal, os membros de uma comunidade cuidam uns dos 
outros, querem-se bem, respeitam-se, ajudam-se, entendem-se e, entre eles, não há estranhos. A palavra "comunidade" evoca, assim, aquilo de que sentimos falta e do que gostaríamos de ter para viver seguros e confiantes; ao "paraíso perdido", narrado pela Bíblia e pela mitologia grega. "Em suma, 'comunidade' é o tipo de mundo que não está, lamentavelmente, ao nosso alcance - mas no qual gostaríamos de viver e esperamos vir a possuir" (BAUMAN, 2003, p. 9).

Mas não é só a dura realidade que torna essa comunidade imaginária um paraíso perdido ou a ser alcançado. Bauman explica que fazer parte de uma " "comunidade realmente existente': uma coletividade que pretende ser a comunidade encarnada, o sonho realizado [...] exige lealdade incondicional" (2003, p.9), uma rigorosa obediência que leva seus membros a abrirem mão da liberdade - também chamada "auto-afirmação", identidade e autonomia - em nome de segurança. Pertencer a uma comunidade seria desfrutar de um pouco de proteção e estabilidade numa época em que "foi-se a maioria dos pontos firmes e solidamente marcados de orientação que sugeriam uma situação social que era mais duradoura, mais segura e mais confiável do que o tempo de uma vida individual" (2003, p. 47).

Bauman (2003) retoma uma reflexão de Tönnies para, no nosso entender, mostrar como o conceito de comunidade altera-se ao longo dos séculos. O que distinguia as comunidades antigas das modernas era o "entendimento compartilhado" entre os membros. Ou seja, havia uma ausência de consenso, de acordo, entre as pessoas que naturalmente possuem diferentes opiniões.

O entendimento não era resultado de debate ou de construção, mas um ponto de partida, um fluído natural que sempre esteve na comunidade, tácito por natureza e, a partir do qual, todos agiam, sem questionamentos. O que os unia era a homogeneidade, a "mesmidade", que, segundo Bauman, evaporou quando a comunicação entre os de dentro e os do mundo exterior passou a ter mais peso do que as trocas entre os integrantes de uma mesma comunidade.

“O golpe mortal na 'naturalidade' do entendimento comunitário foi desferido, porém, pelo advento da informática: a emancipação do fluxo de informação proveniente do transporte dos corpos" (BAUMAN, 2003, p. 18). Com a informática, não é mais possível estabelecer uma fronteira entre o "dentro" e o "fora" e a homogeneidade passa a ser distinta da massa confusa por seleção, separação e exclusão. A unidade precisa ser "construída", sendo que sua única forma é o acordo "artificialmente produzido".

A análise que Bauman faz em seu livro, passando pelo período industrial até a globalização, mostra que o conceito de comunidade no mundo atual é discutido por vários 
teóricos e, algumas vezes, até questionado, em um anúncio de sua falência. Mas o autor não poderia ser visto como um pessimista: embora acredite que a tensão individualidade/comunidade, ou seja, segurança/liberdade provavelmente nunca será resolvida, afirma que precisamos tentar construir uma comunidade. Mas se, em sua opinião, uma comunidade vier a existir:

[...] só poderá ser (e precisa sê-lo) uma comunidade tecida em conjunto a partir do compartilhamento e do cuidado mútuo; uma comunidade de interesse e responsabilidade em relação aos direitos iguais de sermos humanos e igual capacidade de agirmos em defesa desses direitos. (BAUMAN, 2003, p. 134).

Ao contrário de Bauman, Costa (2005) acredita na existência de comunidades hoje, mas não no sentido que classifica como "romântico", do outro autor. E, sim, como fruto do surgimento de novas formas de comunidade, que tornaram mais complexas nossa relação com elas.

Costa se baseia em Wellman e Berkowitz (1988) que procuram pela essência social de comunidades não tomando por base a localidade nem a solidariedade, mas os modos pelos quais as redes de relações informais encaixam pessoas e famílias/negócios em estruturas sociais. A abordagem dos autores se concentra nas características dos laços de 'comunidade' - ligações informais de companheirismo e ajuda entre indivíduos - e no arranjo formado por essas ligações.

A abordagem tem dado aos autores a "flexibilidade para descobrir solidariedades locais e extensas, ramificadas em comunidades" (WELLMAN; BERKOWITZ 1988, p. 131, tradução nossa ${ }^{20}$ ). Mais ainda: tem possibilitado enxergar que atributos de laços e redes melhor promovem relações sociais, assistência interpessoal, controle social informal e um senso de identidade pessoal.

A partir de Wellman e Berkowitz (1988), Costa (2005) defende que houve uma “transmutação do conceito de 'comunidade' em 'rede social' e do princípio de que estamos associados em redes, mas por meio de comunidades pessoais. Nós teríamos consciência dessa rede de relacionamentos, tendo com algumas pessoas laços mais fortes do que com outras. Independente da intensidade, seriam laços importantes e que acabariam dando um novo caráter à noção de comunidade.

De fato, se focarmos diretamente os laços sociais e sistemas informais de troca de recursos, ao invés de focarmos as pessoas vivendo em vizinhanças e pequenas

\footnotetext{
20 "But it has given us the flexibility to discover both local solidarities and far-flung, ramified communities."
} 
cidades, teremos uma imagem das relações interpessoais bem diferente daquela com a qual nos habituamos. Isso nos remete a uma transmutação do conceito de "comunidade" em "rede social". Se solidariedade, vizinhança e parentesco eram aspectos predominantes quando se procurava definir uma comunidade, hoje eles são apenas alguns dentre os muitos padrões possíveis das redes sociais. Atualmente, o que os analistas estruturais procuram avaliar são as formas nas quais padrões estruturais alternativos afetam o fluxo de recursos entre os membros de uma rede social. Estamos diante de novas formas de associação, imersos numa complexidade chamada rede social, com muitas dimensões, e que mobiliza o fluxo de recursos entre inúmeros indivíduos distribuídos segundo padrões variáveis. (COSTA, 2005, grifo nosso).

Concordamos com Costa quanto à necessidade de focar as relações e os laços entre as pessoas nesse contexto, assim como a idéia de "networks as personal communities" ("redes como comunidades pessoais”, tradução nossa), de Wellman e Berkowitz (1988). No entanto, manteríamos o uso das expressões redes e comunidades, entendendo a primeira como uma ampliação da segunda. Nas redes, as pessoas teriam laços mais fracos entre si do que nas comunidades, onde encontraríamos mais proximidade. Esta distinção deve ficar mais clara quando tratarmos das redes sociais, ainda neste capítulo.

Aproveitando a reflexão de Bauman (2003), acreditamos que, em comunidade, as pessoas teriam mais comprometimento umas com as outras, por conta do estreitamento de laços. Nas redes, no entanto, os laços seriam mais frouxos pela própria característica das redes que é a abertura, a fluidez com que as pessoas se agregam e se desligam, havendo, assim, um comprometimento menor entre os participantes.

Como Bauman, pensamos que estar em comunidade oferece uma certa sensação de segurança. Mas, ao contrário do autor, não acreditamos que para tê-la seria necessário abrir mão da individualidade. A individualidade seria respeitada, mas estaria sujeita à negociação com outras individualidades, em uma relação fruto de consenso construído e não de entendimento prévio. Um equilíbrio, portanto, nas tensões individualidade/comunidade e segurança/liberdade conquistado pelo agrupamento.

Todos esses autores nos mostram como definir um objeto é uma tarefa complexa e que varia, assim como o nome a ele dado, de acordo com os autores. Redes sociais e comunidades virtuais podem designar o mesmo objeto ou expor variações. Essa questão deve ficar mais clara quando tratarmos dos conceitos de redes sociais e sua relação com a expressão comunidade. Antes, porém, vamos refletir um pouco a respeito do período de transição em que vivemos que reflete esta dificuldade em se definir comunidade. 


\subsubsection{Comunidade na pós-modernidade}

Toda a incerteza e volatilidade que caracterizam o conceito de comunidade refletiriam o período de transição paradigmática que atravessamos. Entre o paradigma da modernidade e seus sinais de crise - e um novo paradigma, ainda incerto, que, na ausência de nome, Santos (2000, 2006) chama de pós-modernidade. Embora mais evidente no campo epistemológico, essa transição também ocorre no plano geral da sociedade como fruto do esgotamento do processo civilizatório instaurado com a redução das possibilidades da modernidade ao capitalismo.

O paradigma cultural da modernidade cumpriu promessas, algumas delas em excesso e, assim, está superado. Mas deixou de cumprir muitas outras e, na impossibilidade de realizálas, tornou-se obsoleto. Esse desequilíbrio seria o responsável pelo atual momento, que se apresenta superficialmente como um vazio, mas se trataria apenas de uma situação de transição.

Para entender essa transição e encontrar nela sintomas que possam ajudar a formular um novo projeto, é preciso entender a modernidade. Segundo Santos (2000, 2006), o projeto de modernidade caracterizou-se por um equilíbrio entre regulação e emancipação, pilares sobre os quais se sustentava a pré-modernidade.

A regulação se constitui por três princípios: do Estado (Hobbes), do mercado (Locke) e da comunidade (Rousseau). O pilar da emancipação, por sua vez, é composto pela articulação de três racionalidades: moral-prática do direito moderno, cognitivo-experimental da ciência e das técnicas modernas, e a estético-expressiva das artes e da literatura modernas.

Os três princípios de ambos estariam ligados por correspondência e assim, por exemplo, a racionalidade estético-expressiva articular-se-ia com o princípio de comunidade, que traz em si a idéias de comunhão e de identidade, necessárias para a contemplação estética.

A questão é que não houve um equilíbrio entre regulação e emancipação, houve excesso de regulação e a racionalidade cognitivo-instrumental e tecnológica acabou por prevalecer sobre as demais à medida que a modernidade se ligava ao percurso capitalista. É nesse desequilíbrio que nos encontramos.

Para transcender a modernidade, seria preciso encontrar nela elementos para formular um novo paradigma. Santos (2000) acredita que, de todas as representações da modernidade, o princípio da comunidade, no domínio da regulação, e a racionalidade estético-expressiva, no domínio da emancipação, são as mais inacabadas e abertas. 
O princípio da comunidade teria sido o mais negligenciado nos últimos duzentos anos e, assim, o menos obstruído por determinações e mais bem colocado para instaurar uma dialética positiva com o pilar da emancipação (SANTOS, 2000, p. 75). Como mostramos anteriormente, trata-se de uma representação cujos elementos constitutivos estão inacabados e abertos; ela mesma, como vimos, é de difícil representação.

Ao contrário dos princípios de mercado e Estado, a comunidade não foi cooptada pelo utopismo automático da ciência, pagando pelo seu esquecimento. Mas, graças a esse distanciamento, manteve-se aberta a novos contextos, por exemplo, o ciberespaço, em nosso entender. Nesses novos contextos, por meio da comunidade, acreditamos que podemos esperar alguma transformação.

Santos (2000) ressalta duas dimensões do princípio da comunidade para determinar suas "virtualidades epistemológicas". Participação e solidariedade tiveram muito pouco de si "colonizados" pela ciência moderna. A primeira (participação) foi colonizada em parte no contexto do que a ciência política liberal definiu como sendo esfera política (cidadania e democracia participativa), mas muito sobrou para que a participação da comunidade pudesse ser explorada em outros domínios. A solidariedade, da mesma forma, foi colonizada de forma incompleta, ocorrendo através das políticas sociais do Estado-Providência. É a solidariedade que "converte a comunidade no campo privilegiado do conhecimento emancipatório" (SANTOS, 2000, p. 81). Voltaremos a este ponto ao longo desta pesquisa.

Esta contextualização e exposição de possibilidades a serem exploradas nessa fase de transição, e os conceitos e leituras a respeito de comunidade vistos anteriormente, visam entender que, depois de duzentos anos de desterritorialização das relações sociais, não é possível limitar a comunidade a uma área contígua (local) nem a uma temporalidade. $\mathrm{Na}$ opacidade em que vivemos, a comunidade é o local-global, o imediato-deferido, como defende Santos (2000, p. 81): "a neo-comunidade transforma o local numa forma de percepção global, e o imediato numa forma de percepção do futuro".

A comunidade, enfim:

É um campo simbólico em que se desenvolvem territorialidades e temporalidades específicas que nos permitem conceber o nosso próximo numa teia intersubjetiva de reciprocidades (SANTOS, 2000, p.81).

Acreditamos que o entendimento de campo simbólico se aplica tanto à comunidade quanto à rede social no contexto do ciberespaço. Da revisão bibliográfica que apresentamos, 
parece-nos o mais adequado para refletir sobre as redes e comunidades virtuais de aprendizagem, na quais se entrelaçam subjetividades sob a experiência da aprendizagem.

\subsection{Rede}

“A nossa época será marcada pelo 'fenômeno rede'. Como todos os fenômenos morfológicos profundos, de caráter universal, o fenômeno rede pertence não só à ciência como à vida social" (ROSENTHIEL, 1988, p. 228). As frases que iniciam o capítulo "Rede", da Enciclopédia italiana Einaudi ${ }^{21}$, anunciam a importância de compreendermos esse "fenômeno", principalmente sendo nós investigadores de redes e comunidades de aprendizagem no ciberespaço.

$\mathrm{Na}$ atual sociedade, as funções e os processos dominantes estariam organizados em redes. "Redes constituem a nova morfologia social de nossas sociedades e a difusão da lógica de redes modifica de forma substancial a operação e os resultados dos processos produtivos e de experiência, de poder e de cultura", acredita Castells (1999, p. 565), que fundamenta esta pesquisa.

Pierre Musso é outro autor que entende a idéia de rede como "onipresente, e mesmo onipotente, em todas as disciplinas" (2004, p. 17), citando as seguintes:

- Física: rede se identifica com a análise de cristais e sistemas desordenados;

- Matemática, informática e inteligência artificial: rede define modos de conexão (teoria dos grafos, cálculos sobre redes);

- Tecnologias: a rede é estrutura elementar das telecomunicações;

- Economia: relações entre atores em escala internacional (redes financeiras, comerciais) ou elaborar modelos teóricos;

- Biologia: análise do corpo humano;

- Ciências sociais: define modos de organização ou sistemas de relações (redes sociais, de poder).

Ao recuperar a gênese da palavra "rede", Musso (2004) descobriu que ela já existia na mitologia através do labirinto. Na Antigüidade, Hipócrates associou a noção de rede definitivamente à metáfora do organismo, a partir da comunicação entre as veias. Musso (2004) explica ainda que a palavra (réseau) só apareceu na língua francesa no século XII para designar redes de caça ou de pesca, cestas, tecidos e malhas que estão em torno do corpo. No século XVI, o termo em francês significava os véus e rendas que cobriam a cabeça das

${ }^{21}$ Enciclopédia Einaudi, vol. 13, Lógica-Combinatória. Porto: Imprensa Nacional / Casa da Moeda: 1998. 
mulheres. No século XVII, a rede passou para dentro do corpo humano. O naturalista e médico italiano Marcelo Malpighi (1628-1694) levou o vocábulo para a ciência para descrever o "corpo reticular da pele".

A gênese descrita por Musso (2004) relata que há uma grande ruptura na virada do século XVIII para o XIX quando a rede passa a se distinguir do corpo humano. Não está mais apenas sobre o corpo (feita pelos tecelões) ou observada dentro dele (pelos médicos). A rede torna-se artefato e técnica autônoma e, assim, construída (pelos engenheiros). Na distinção do corpo, a rede "pode ser construída porque ela se torna objeto pensado em sua relação com o espaço" (1988, p. 20).

Naquele mesmo período, Leonhard Euler criou a Teoria Geral dos Grafos. Grafo é um “conjunto cujos elementos são unidos por arcos" (HOUAISS, 2002). Em qualquer rede há um grafo e é por isto que qualquer teoria particular de redes busca na Teoria Geral dos Grafos os seus teoremas topológicos fundamentais (ROSENTHIEL, 1988).

As redes elétricas constituem, segundo Rosenthiel, a classe mais antiga e é um exemplo de rede particular, que possui especificidades para além da Teoria Geral dos Grafos. As ciências sociais, que vêm se beneficiando das análises de redes, pelo contrário, oferecem exemplos mais gerais e raramente têm uma teoria particular de redes. Embora a teoria tenha sido criada em 1736, os estudos de redes aplicados às relações foram resgatados recentemente em vários campos da ciência, denominando, muitas vezes como a "nova ciência das redes". Ela contribui, por exemplo, para os estudos das redes sociais no ciberespaço, como veremos mais adiante.

Castells define rede como "um conjunto de nós interconectados"; nó, por sua vez, "é o ponto no qual uma curva se entrecorta” (1999, p. 566). Antes de tudo, uma rede é constituída por nós que podem ser quaisquer objetos: memórias, lugares, etc.; depois por ligações de duas a duas: uma ligação é incidente a dois nós e, dependendo do caso, é orientada de um nó para o outro ou não, segundo Rosenthiel. "Aos nós e ligações podem ser associadas variáveis" e "para qualquer tipo de rede há leis específicas que ligam as variáveis de qualquer nó e as ligações que lhe são incidentes" (ROSENTHIEL, 1988, p. 228). Os nós podem ser dependentes por meio de outros nós se não tiverem ligação incidente comum. "A rede é um esquema típico em que as transformações do conjunto são descritas por transformações locais" (p. 229).

Hoje, o mais comum seria associarmos a palavra rede ao ciberespaço, à tecnologia e as relações sociais. Rheingold (1996) e Lévy (1999), dois autores que contribuem com esta dissertação, geralmente empregam "rede" para indicar a infra-estrutura tecnológica, a 
interconexão entre computadores, enfim, os aspectos físicos que permitem às pessoas se encontrarem e se relacionarem no espaço online. Mas, ao se referirem às relações humanas, empregam o termo "comunidade virtual", enquanto outros autores (COSTA, 2005 e RECUERO, 2005) referem-se às mesmas relações como redes sociais online - exemplo da não uniformidade de conceitos e expressões.

A descentralidade, o caráter distributivo, a expansão ilimitada e a multidirecionalidade são elementos de rede que caracterizam o ciberespaço. Paradoxalmente, esses processos são assegurados por um governo que coordena a rede, no caso, a Internet. "Isso envolve, essencialmente, o desenvolvimento de protocolos compartilhados e acordo quanto a padrões e atribuições de nomes e endereços na Internet" (CASTELLS, 2003, p. 29). A partir desse centro, no entanto, a estrutura descentralizada expande-se, com cada novo nó que a ela se integra.

O governo teve início na década de 1960 quando a ARPA (Agência de Projetos de Pesquisas Avançadas do Departamento de Defesa dos Estados Unidos) era a autoridade sobre a rede e o Network Working Group (NWG) produziu os padrões técnicos. Outros atores e organizações foram tomando parte no processo de coordenação da Internet até que, em 1998, foi criada, por meio de aprovação de projeto pelo governo dos EUA, a Internet Corporation for Assigned Names and Numbers (ICANN), corporação privada, sem fins lucrativos, formada por representantes de organizações envolvidas com a Internet e pessoas com conhecimento técnico, ambas de várias partes do mundo, que pleitearam serem candidatas e se submeterem à votação eletrônica mundial. A ICANN administra os endereços de IP, os sistemas de nomes de domínio e de servidores de raiz, e atribui parâmetros de protocolo - funções desempenhadas sob contrato do governo dos EUA.

\footnotetext{
A visão romântica de uma comunidade global da Internet se auto-representando por meio de voto eletrônico deve ser temperada com a realidade dos lobbies, das potentes redes de apoio e reconhecimento de nomes em favor de certos candidatos. E não faltam críticas bem formuladas ao governo da ICANN. (CASTELLS, 2003, p. $31)$.
}

Lobbies à parte, esse governo tem mantido a maioria dos valores e usos das culturas que estruturaram a Internet, como o compartilhamento e o espírito de liberdade, permitindo às pessoas interagirem e constituírem o que chamamos de redes sociais online. 


\subsubsection{Rede social online}

A partir da idéia de nós e interconexões, Marteleto (2001) define rede social como "um conjunto de participantes autônomos, unindo idéias e recursos em torno de valores e interesses compartilhados". Em detrimento às estruturas hierárquicas, as pessoas em rede valorizam os elos informais e as relações entre elas. E, assim, "os indivíduos, dotados de recursos e capacidades propositivas, organizam suas ações nos próprios espaços políticos em função de socializações e mobilizações suscitadas pelo próprio desenvolvimento das redes".

As pessoas em rede trocam e compartilham idéias de forma fluída e aberta, enquanto seus interesses forem os mesmos do conjunto. Elas criam um sistema aberto e dinâmico cuja estrutura é capaz de se "expandir de forma ilimitada integrando novos nós desde que consigam comunicar-se dentro da rede, ou seja, desde que compartilhem os mesmos códigos de comunicação [...]" (CASTELLS, 1999, p. 566).

Para entender o sistema de redes de pessoas no ciberespaço, recorremos à Recuero (2005), pesquisadora de redes sociais na Internet e comunidades virtuais, com doutorado no tema. Ela parte da Análise de Redes Sociais, baseada na Sociometria e na Teoria dos Grafos (DEGENNE e FORSÉ, 1999) que, por sua vez, tem suas bases nas décadas de 60 e 70 (WELLMANN, 1988) para caracterizar rede social "como um conjunto de dois elementos: atores (pessoas, instituições ou grupos) e suas conexões [...]. Essas conexões são entendidas como os laços e relações sociais que ligam as pessoas através da interação social" (RECUERO, 2005), uma intersecção entre os modelos matemáticos e os estruturaisfuncionalistas.

Após ampla revisão da literatura, a pesquisadora acredita que a aplicação direta de modelos da "ciência das redes" aos sistemas sociais não é capaz de dar conta desses objetos de forma integral. Questões essenciais permaneceriam:

A perspectiva parece pressupor a conexão entre os atores de forma igual, sem salientar sua qualidade, sua profundidade e suas especificidades, que em redes sociais, podem fazer diferença. Sem levar em conta o custo do laço social e presumindo sua existência, os modelos podem levar a conclusões enganosas quando aplicados diretamente para os sistemas sociais. Outro senão é a incapacidade dos modelos de observar os vários sentidos nos quais as relações sociais acontecem, como o contexto e o capital social gerado fazem parte de cada interação em uma rede social. Os modelos também falham em levar em conta essas diferenças (Primo e Recuero, 2003 e 2004; Recuero, 2004). Nota-se que, enquanto a maioria dos problemas dos modelos teóricos da "ciência das redes" vem da falta de atenção para com a interação social, a abordagem sociológica supre esta lacuna com especial atenção para a estrutura. Entretanto, a abordagem sociológica, por demais formal, tem dificuldades para observar o estudo da dinâmica dessas redes, considerando-as como isoladas no tempo e espaço (RECUERO, 2005). 
Nesse sentido, Recuero (2005) apresenta uma proposta de modelo de estudo das comunidades virtuais (compreendendo-as como redes sociais) a partir de diálogos entre as teorias sistêmicas, cibernéticas, a ciência das redes e os estudos sociais.

Em alguns autores, encontramos a estrutura, a organização e a dinâmica dos processos da rede social como elementos fundamentais para o estudo dos sistemas (MATURANA e VARELA (2001), PARSONS (1969), GALLIANO (1981)). Segundo Recuero (2005), a estrutura é o que um grupo tem de mais permanente nos modos de agir e das relações sociais. A organização trabalha com as relações, o conjunto de elementos que faz parte da estrutura, constituindo a substância do extrato social. Já a dinâmica diz respeito às adaptações e modificações pelas quais as redes passam ao longo do tempo.

\section{Organização}

Na totalidade das relações, pode-se dizer que a "organização é composta pelas relações entre membros de um grupo, ou seja, pela interação social. A interação é sempre um processo comunicacional, uma ação que tem um reflexo comunicativo entre o indivíduo e seus pares, como reflexo social" (WATZLAVICK; BEAVIN; JACKSON, 2000 apud RECUERO 2005, grifo nosso).

O verbo latino "agere" significa pôr em movimento. "A ação não se resume a um mero fazer, o que não nos distinguiria do animal, mas se trata de um fazer consciente, impregnado de significado e simbioticamente articulado com a palavra." (MACHADO, 2008, p. 14). O fazer humano pressupõe sempre uma reflexão, uma antecipação sobre suas conseqüências.

A interação é uma palavra formada por derivação sufixal, por meio da adição do prefixo "inter" à palavra "ação": inter + ação. "Inter" significa "no interior de dois; entre; no espaço de", segundo o dicionário Houaiss (2002), que define interação como:

- influência mútua de órgãos ou organismos inter-relacionados;

- ação recíproca entre dois ou mais corpos;

- atividade ou trabalho compartilhado, em que existem trocas e influências recíprocas;

- comunicação entre pessoas que convivem; diálogo, trato, contato;

- intervenção e controle, feitos pelo usuário, do curso das atividades num programa de computador, num CD-ROM etc. 
Pelos excertos acima, percebemos que a "ação" sempre se faz presente nos processos interativos e, assim, interação é sempre ação. A partir de Lakatos e Marconi (1999), Recuero (2005) ressalta que, para o objetivo desta reflexão, tendo naturezas diferentes, a interação social influencia processos sociais que culminam em cooperação, competição e conflito, como será visto na dinâmica das redes.

\section{Estrutura}

A estrutura da rede social é o resultado das interações repetidas, compreendendo o que ela possui de mais permanente. Essa sedimentação das trocas pode ser conferida por meio do capital social e dos laços sociais (RECUERO, 2005).

Vimos, anteriormente, que Costa (2005) propõe uma "transmutação do conceito de comunidade em rede social" principalmente por considerar os laços sociais e os sistemas de troca informais em vez das pessoas e suas relações de parentesco e vizinhança, que melhor caracterizavam uma comunidade no passado.

Segundo Recuero (2005), o conceito de laço social está ligado à interação social, sendo também chamado laço relacional, em contraposição ao laço associativo, que são conexões formais independentes da vontade do indivíduo. Tanto a pesquisadora quanto Costa explicam, a partir de Granovetter (1973), que os laços sociais podem ser fortes, caracterizando-se pela intimidade e pela proximidade, e fracos, nas quais as relações são mais distantes. Os laços fortes constituem a estrutura social de um grupo, caracterizando redes menos instáveis. Sendo assim, o estudo dos laços contribui para que se compreenda a estrutura de uma rede social.

A estrutura de uma rede também pode ser observada por meio do capital social.

Essa noção poderia ser entendida como: a capacidade de interação dos indivíduos, seu potencial para interagir com os que estão a sua volta, com seus parentes, amigos, colegas de trabalho, mas também com os que estão distantes e que podem ser acessados remotamente. Capital social significaria aqui a capacidade de os indivíduos produzirem suas próprias redes, suas comunidades pessoais. (COSTA, 2005).

Para Putnam (apud RECUERO, 2005), o capital social refere-se à conexão entre os indivíduos e a confiança e reciprocidade que emergem dela. Já para Bourdie (apud RECUERO, 2005), o capital social é o "agregado dos recursos atuais e potenciais os quais 
estão conectados com a posse de uma rede durável, de relações de conhecimento e reconhecimento mais ou menos institucionalizadas, ou em outras palavras, à associação a um grupo".

São dois conceitos diferenciados. Recuero (2005) explica que, para Putnam, o capital social é o "conjunto de recursos possuído pelo grupo, enquanto para Bourdieu, ele é uma conseqüência das relações sociais, que é percebida pelos envolvidos in abstracto [...], mas pode ser construído e acessado apenas individualmente". Ou seja, para Bourdieu, são os indivíduos que efetivamente constroem e acessam.

\section{Dinâmica}

As mudanças que caracterizam uma rede ao longo do tempo são um padrão importante para compreendê-la. Podemos percebê-las por meio das interações, que constituem a organização da rede e que afetam sua estrutura.

Recuero (2005) elenca seis dinâmicas verificadas nas redes sociais:

- Ruptura e agregação: a autora cita como exemplo os canais de chat, no qual observou que quanto maior o número de pessoas, maior a quantidade de conflitos e a formação de pequenos grupos. Após revisitar alguns autores, como Allen (2004), concluí que o processo de conflito seria tão importante quanto o de cooperação para que os grupos fiquem em tamanhos que tornem possível a interação social.

- Comportamentos emergentes: característica dos sistemas complexos (JOHNSON, 2003). O aparecimento da ordem em sistemas caóticos, a auto-organização e a adaptação dos sistemas são considerados comportamentos emergentes. Exemplo: o aparecimento de redes sociais pode ser considerado um comportamento emergente e auto-organizado.

- Adaptação e auto-organização: as mudanças ao longo do tempo implicam no aparecimento de novos padrões estruturais. Assim, as redes sociais precisam ter a capacidade de adaptação, um equilíbrio dinâmico, constantemente redirecionado entre caos e ordem. As redes adaptam-se ao ambiente.

- Sincronia: forma de surgimento de "ordem espontânea" em um sistema complexo, quando "as mesmas coisas acontecem ao mesmo tempo" (STROGATZ, 2003). Trata-se de uma ordem emergente, não acordada entre os pares, mas que aparecem das interações coletivas, por meio do surgimento de um determinado ritmo. 
- "Clusterização": Barabási (2003) explica que há a presença de conectores nas redes, ou seja, os indivíduos com mais conexões com outras pessoas do que a média do grupo. A presença de conectores caracteriza o que se chama de "clusterizaçao" em uma rede - nós extremamente conectados.

- Processos de cooperação, competição e conflito: esses processos sociais emergem das interações, segundo Lakatos e Marconi (1999). Cooperação seria atuar em conjunto para alcançar um objetivo comum. A competição, o resultado das diferenças entre desejo e aspirações e a capacidade de provê-los. O conflito seria diferente da competição na medida em que envolve hostilidade e pessoalidade.

\title{
Rede $x$ comunidade
}

Deixamos os processos de cooperação, competição e conflito por último porque a cooperação seria o principal elemento distintivo entre as redes sociais online e as comunidades virtuais. Para Recuero, na estrutura de uma comunidade, "a maioria das relações precisa ser cooperativa", apesar de poder existir conflitos.

\begin{abstract}
A interação que é cooperativa pode gerar a sedimentação das relações sociais, proporcionando o surgimento de uma estrutura. Quanto mais interações cooperativas, mais forte se torna o laço social desta estrutura, podendo gerar um grupo coeso e organizado. Na organização da comunidade virtual, portanto, é necessário que exista uma predominância de interações cooperativas, no sentido de gerar e manter sua estrutura de comunidade. (RECUERO, 2005, grifo nosso).
\end{abstract}

Assim, no que diz respeito à organização, verifica-se a formação de uma comunidade em redes sociais cuja estrutura apresenta laços fortes, que a mantêm. Ao redor deles, existiriam laços fracos, compostos de integrantes que poderiam fazer parte do grupo ou não. Quanto à dinâmica da comunidade, ela deve ser "adaptativa, auto-organizada e cooperativa” (RECUERO 2005). Sincronismo e clusterização também são esperados, já que demonstram uma estrutura coesa, embora essas dinâmicas não sejam restritas às comunidades virtuais e aparecem em várias redes sociais.

Temos observado nas redes sociais e comunidades virtuais que pesquisamos a organização sugerida por Recuero. Vemos que uma comunidade virtual pode situar-se dentro de uma rede social no ciberespaço, mas também constituir-se comunidade como um todo, o que poderia ser encontrado em agrupamentos com um número reduzido de participantes, mas não se restringindo a ele. 
Parece-nos, ao chegar neste ponto, que a distinção entre rede social e comunidade virtual estaria na intensidade dos elementos fundamentais das redes. Diríamos que nas comunidades virtuais encontramos:

- laços fortes que formam um grupo sólido;

- cooperação constante entre os integrantes;

- alto grau de adaptação, auto-organização e sincronismo.

As interações nas redes sociais, por sua vez, apresentariam características mais ligadas ao próprio conceito de rede: fluidas, multidirecionais, ilimitadas. O que não significa que não possamos encontrar cooperação entre as pessoas das redes sociais, mas que a cooperação apareceria de forma esparsa, por conta dos laços fracos que os unem. Esse entendimento deve ficar mais claro no exemplo que apresentaremos a seguir, a rede social "Blogs Educativos".

\subsection{A lista "Blogs Educativos": rede e comunidade virtual}

No início de 2008, ingressei na lista de discussão online "Blogs Educativos: Blogs, Internet e Web na Educação" 22 . O grupo destina-se "à troca de experiências entre professores, do ensino fundamental e médio, sobre o uso da Internet e da Web como ferramentas de aprendizagem colaborativas, além de discutir as inúmeras possibilidades educacionais dos weblogs" ${ }^{23}$, como explica a página inicial da lista:

\footnotetext{
${ }^{22}$ Disponível no endereço <http://br.groups.yahoo.com/group/blogs_educativos/>. Acesso em 06 fev. 2005.
} 


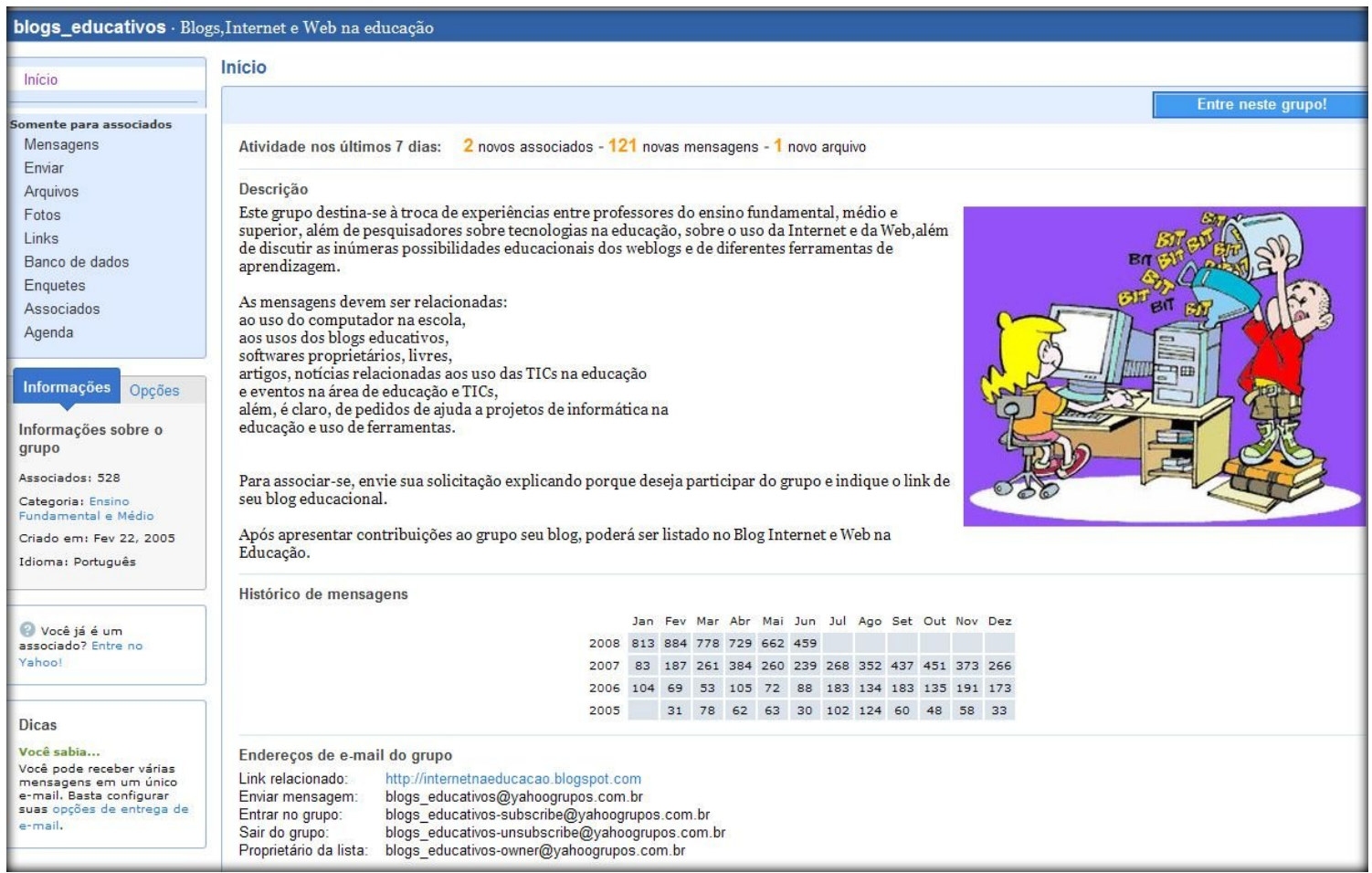

Figura 1: Homepage da lista de discussão Blogs Educativos Fonte: Reprodução

Em 23 de junho de 2008, quando a reprodução acima foi produzida, a rede possuía 530 integrantes e contabilizava mais de nove mil mensagens em mais de três anos de existência (criada em 22 de fevereiro de 2005), como mostra o quadro a seguir:

\begin{tabular}{|c|c|c|c|c|c|c|c|c|c|c|c|c|c|}
\hline & Jan & Fev & Mar & Abr & Mai & Jun & Jul & Ago & Set & Out Nov & Dez \\
\hline 2008 & 813 & 884 & 778 & 729 & 662 & 459 & & & & & & \\
\hline 2007 & 83 & 187 & 261 & 384 & 260 & 239 & 268 & 352 & 437 & 451 & 373 & 266 \\
\hline 2006 & 104 & 69 & 53 & 105 & 72 & 88 & 183 & 134 & 183 & 135 & 191 & 173 \\
\hline 2005 & & 31 & 78 & 62 & 63 & 30 & 102 & 124 & 60 & 48 & 58 & 33 \\
\hline
\end{tabular}

Figura 2: Total de mensagens da lista de discussão Blogs Educativos Fonte: Reprodução

A primeira ação como nova integrante da rede social Blogs Educativos foi enviar uma mensagem de apresentação, perguntando, de imediato, se aquela lista poderia ser chamada de comunidade virtual de aprendizagem. Abaixo, a reprodução dessa mensagem. 


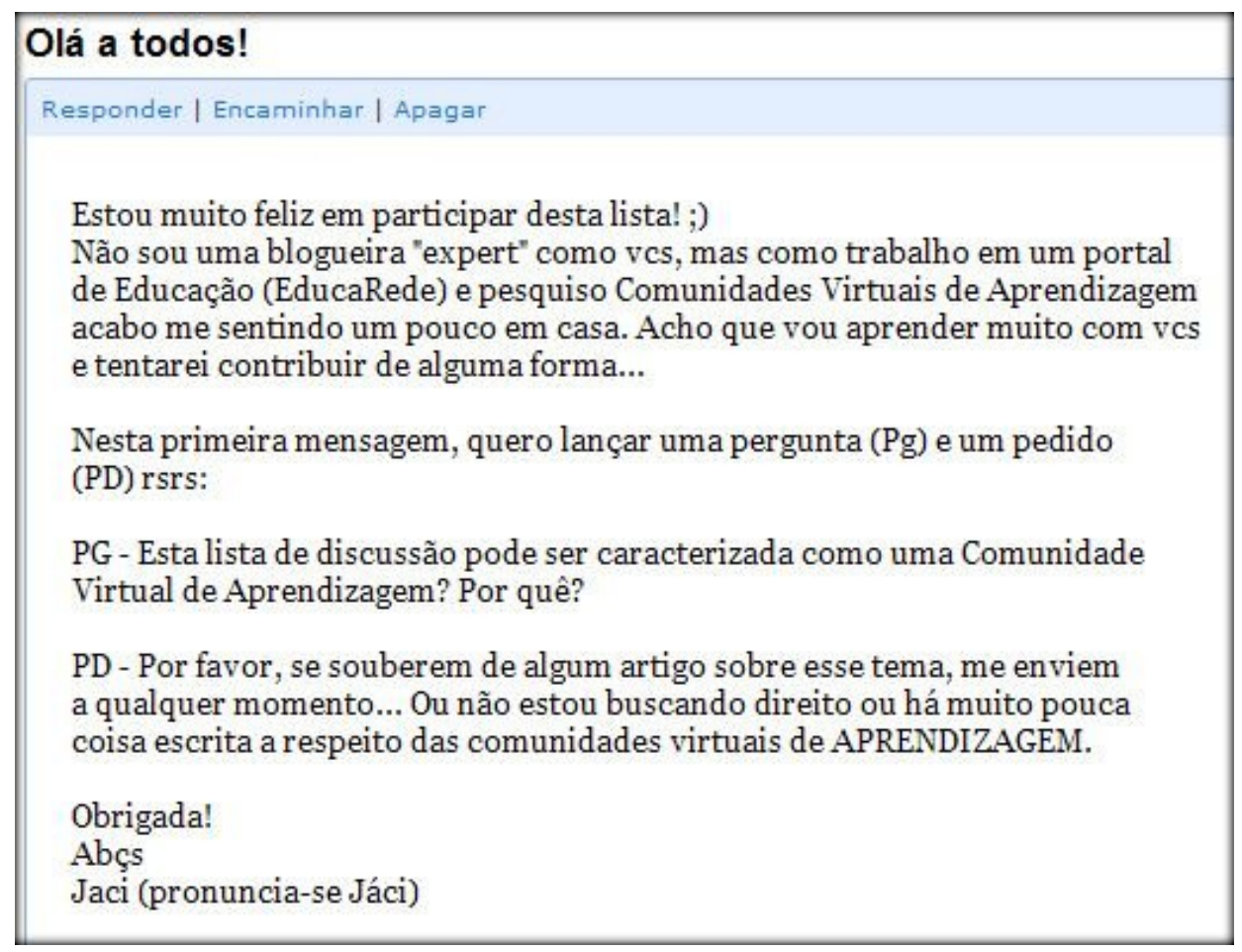

Figura 3: Primeira mensagem enviada pela pesquisadora à lista de discussão Fonte: Reprodução

Essa primeira mensagem foi enviada em seis de fevereiro de 2008 e, em dois dias, recebi sete respostas de boas-vindas, que também comentavam a pergunta que eu havia feito. De modo geral, todos achavam que aquela lista de discussão era uma comunidade virtual de aprendizagem.

Daquelas opiniões, no entanto, a que mais estava de acordo com as leituras que eu realizava na época foi a resposta de Suzana Gutierrez, então doutoranda em Educação na Universidade Federal do Rio Grande do Sul. A seguir, a reprodução de um trecho da mensagem em que Suzana faz distinção entre comunidade e rede. 


\begin{abstract}
No meu entender a comunidade não é um organismo, uma "coisa". A comunidade se manifesta pelas relações sociais que se formam entre um grupo de pessoas. 0 simples partilhar de interesses comuns não garante a emergência de relações sociais que possam definir um grupo como comunidade.

Uma definição que usei, em parte baseada em Boaventura de Sousa Santos (200o, A Crítica da Razão Indolente):

"Pessoas reunidas em torno de interesses comuns constituem uma/rede/ que, à medida que vai se desenvolvendo a convivência e consolidando as relações entre as pessoas, tende a operar como uma_comunidade_. Comunidade como um tipo de relação social entre pessoas, onde prevalece o cuidado e a solidariedade como dimensões éticas e a participação como dimensão política " (Gutierrez, 2004, dissertação)
\end{abstract}

Figura 4: Resposta de Suzana Gutierrez enviada à lista de discussão Fonte: Reprodução

Com o passar dos meses, percebi, na prática, o que Suzana havia escrito naquela mensagem, fruto de sua dissertação de mestrado. De fato, das mais de quinhentas pessoas inscritas naquela lista de discussão, apenas um grupo pequeno respondia e enviava mensagens com freqüência, em um diálogo pergunta-resposta diário. Por meio do conteúdo daquelas trocas, parecia haver mais do que interesses em comuns, havia amizade e preocupação com o outro; havia "cuidado e solidariedade como dimensão ética e a participação como dimensão política." (GUTIERREZ, 2004, p. 187).

Os integrantes orientavam como resolver dúvidas técnicas uns aos outros, debatiam questões apresentadas, divulgavam eventos e empregos e até mesmo marcavam encontros presenciais para conversar ou para visitar a escola do colega. Enfim, colaboravam uns com os outros, formando, dentro daquela rede de mais de quinhentas pessoas, uma comunidade virtual.

Nessas interações, percebem-se as características apontadas por Recuero (2005) nas comunidades virtuais: laços fortes que formam um grupo mais sólido, cooperação constante entre os integrantes, forte capital social e alto grau de adaptação, auto-organização e sincronismo.

Havia uma aparente relação de confiança entre essas pessoas que estão distantes geograficamente uma das outras: São Paulo, Porto Alegre, Rio de Janeiro. Para Costa (2005), a confiança entre os indivíduos, em maior ou menor grau, é condição básica para o estabelecimento de uma rede social. “A construção dessa confiança está diretamente relacionada com a capacidade que cada um teria de entrar em relação com os outros, de perceber o outro e incluí-lo em seu universo de referência” (p. 243). 
A inclusão diz respeito ao reconhecimento, no outro, de suas habilidades, competências, conhecimentos, hábitos... Quanto mais um membro interage com os demais, mais ele amplia e fortalece suas redes. Quando a confiança se consolida entre os membros de uma rede, eles passariam a formar uma comunidade, embora para manter a confiança sejam necessários investimentos freqüentes.

Como eu enviava poucas mensagens e respostas, sentia que participava de uma rede social, mas não de uma comunidade. Depois de algumas semanas sem postar mensagem e comentar as dos demais, enviei uma questão àquela rede e não obtive resposta. Seria pela falta de manifestação anterior? Sim: seria preciso dar para receber.

Enquanto interagia na rede, percebi uma certa "cobrança" do grupo para contribuir com as discussões. As pessoas estariam puxando-me para o núcleo da estrutura, já que mantínhamos laços fracos? Senti essa "cobrança", principalmente, quando me solicitaram o compartilhamento de informações a respeito de um grande evento para o qual outros da lista não puderam estar.

Tratava-se da participação no maior encontro presencial de comunidades virtuais no país, a Campus Party, realizado em São Paulo, em fevereiro de 2008. Integrantes da lista pediram àqueles que tinham participado do evento que compartilhassem suas impressões. Esses registros, em geral, são realizados nos blogs pessoais dos membros daquela rede (embora nem todos possuam), e, então, visitados pelos integrantes da lista de discussão.

Esta pesquisadora possui um blog chamado "WebEduca"24, criado um ano antes de ingressar na lista de discussão, para registrar reflexões a respeito do desenvolvimento desta pesquisa, além de desejar receber colaborações de qualquer internauta. As observações sobre o evento Campus Party foram feitas em meu blog pessoal, lidas e comentadas por alguns integrantes da lista de discussão que se interessaram pelo assunto, além de outros internautas.

Uma vez que a contribuição àquela rede pode ser dada por meio do blog individual dos participantes, e não necessariamente de envio de mensagem à lista de discussão, há uma ampliação das trocas para além daquele grupo, uma contribuição para todos que freqüentam o ciberespaço e acessam os blogs.

\footnotetext{
${ }^{24}$ Disponível em <http://webeduca.wordpress.com>. Acesso em 23 jun. 2008.
} 


\title{
1.4.1 Uma tentativa de distinção
}

Acreditamos que a lista de discussão "Blogs Educativos" seria o que Harasim et al (2005) chama de "rede de conhecimento", na qual os participantes compartilham o objetivo de procurar informações e de encontrar meios para entendê-las. As informações são adquiridas por intermédio dos participantes e no próprio ciberespaço e se transformam em conhecimento durante o processo de interação, na qual aprendem a usá-las.

Os educadores que participam da lista "Blogs Educativos" estão entre os participantes potenciais das redes de conhecimento, citados pelos autores: professor à procura de informações para uma aula, médicos que desejam discutir novo tratamento...

\begin{abstract}
As redes de conhecimento se baseiam na aprendizagem e no crescimento autodirigidos, obtidos por meio de informações, técnicas e conhecimento. Não há currículo prescrito; a aprendizagem ocorre através da interação com colegas e especialistas em qualquer assunto ou campo nos quais os usuários estejam interessados - ligados a trabalho, lazer, relacionamentos pessoais ou atividades da comunidade. O aluno pode construir um currículo recorrendo à extraordinária variedade de recursos disponíveis na Internet ou em qualquer rede (HARASIM et al, 2005, p. 30).
\end{abstract}

As redes de conhecimento, como Harasim et al. refere-se, equivalem nesta pesquisa às redes sociais online por entendermos que uma pessoa pode construir conhecimento e trocar informações em qualquer agrupamento do ciberespaço, mesmo aqueles cujo objetivo é apenas fazer amizades.

Entre as redes sociais online, verifica-se a existência de agrupamentos que envolvem um processo de ensino, ou seja, situações didáticas a partir da intencionalidade de formar pessoas, assunto do capítulo 2. Essa característica não foi encontrada na lista "Blogs Educativos", na qual os participantes também aprendem, mas a aprendizagem não parte de um projeto a ser cumprido pela rede.

Alguns grupos online são desarticulados e muito informais, não possuindo um moderador para organizar a discussão. Em outros, há moderadores e restrições ao que é tratado, que precisa se ater ao foco da rede. A lista "Blogs Educativos" possui uma moderadora, a professora Fátima Franco, que, por vezes, chama atenção de mensagens que não estariam de acordo com a temática Educação e Tecnologias de Informação e Comunicação.

A moderadora também autoriza a entrada de pessoas na lista de discussão e esclarece dúvidas quanto aos combinados firmados quando a rede foi criada. Por ser aberta, a lista 
incorpora novos participantes a cada dia e ela seria a referência histórica e de autoridade para organização daquele agrupamento.

Quando esta pesquisadora ingressou à lista "Blogs Educativos" acreditava que aquela era uma comunidade virtual de aprendizagem. Não só porque aquele agrupamento se encaixava no modelo organizador do pensamento (Moreno et al., 1999) que norteava minhas ações no período, como também a leitura das mensagens trocadas pelos participantes revelava que as pessoas aprendiam por meio da troca com os demais membros.

Mas, em uma investigação científica, a dúvida tem que ser exercitada, como explicitado no conteúdo da primeira mensagem enviada pela pesquisadora, questionando ser aquela lista uma comunidade virtual de aprendizagem. A dúvida permaneceu até buscarmos referenciais teóricos a respeito e examinarmos outras duas redes que apresentam um processo de ensino, conteúdo dos próximos capítulos.

\subsection{Redes sociais e comunidades virtuais: iguais e diferentes}

A partir dos autores vistos neste primeiro capítulo, e da análise das redes e comunidades apresentadas nesta dissertação, conseguimos tecer um entendimento acerca do que seriam as comunidades e as redes sociais online.

Agrupamentos de pessoas no ciberespaço, os membros das redes e comunidades "desenvolvem territorialidades e temporalidades específicas" em uma "teia intersubjetiva de reciprocidades" (SANTOS, 2000).

Como na polis grega, seus integrantes teriam a mesmas oportunidades para se expressarem e, nesse sentido, seriam iguais. A formação da comunidade e da rede social online resultaria do agir e do falar em conjunto, não importando o "local" em que seus membros estejam reunidos no ciberespaço. Como escreveu Arendt (2005) a respeito da polis, a ação e o discurso permitem ao homem a criação de um espaço que independe de tempo e lugar, um "espaço da aparência", no qual as pessoas aparecem umas as outras.

$\mathrm{Na}$ imensidão do ciberespaço, pertencer a uma rede social e/ou comunidade pode conferir certa sensação de segurança em um mundo "em que tudo se move e se desloca, em que nada é certo" (HOBSBAWN apud BAUMAN, 2003). No entanto, pesquisadores revelam que esse pertencimento pode variar de acordo com a intensidade dos laços confeccionados entre os participantes, que podem ser fortes ou fracos (WELLMAN; BERKOWITZ, 1988). 
Por meio de Recuero (2005), encontramos a sistematização do que já havíamos percebido empiricamente: uma distinção entre o que podemos chamar de rede social online e comunidade virtual a partir da intensidade dos laços e dos processos de cooperação entre as pessoas. Nas comunidades virtuais, encontraríamos laços mais fortes confeccionados pela cooperação/colaboração freqüente entre seus membros. A variação do grau de relacionamento entre as pessoas de um agrupamento foi exemplificada por meio da rede social "Blogs Educativos", identificada como uma rede social que possui comunidades virtuais em si.

Bauman (2003) também contribui com essa distinção - sem fazê-la - ao enfatizar a necessidade de compromisso e cuidado mútuo entre os integrantes de uma comunidade, também destacada por Gutierrez (2004, dissertação). Entendemos que nas comunidades há o comprometimento, enquanto relações mais frouxas, diluídas, móveis seriam encontradas nas redes sociais online, concordando, inclusive, com o próprio desenho de rede.

A análise da rede social "Blogs Educativos", neste capítulo, da rede de aprendizagem "POIEs do Butantã", no capítulo 2, e da comunidade virtual de aprendizagem Ensinando em Ambientes Virtuais 1, no capítulo 3, confirmariam a distinção assumida neste trabalho. 


\section{REDES DE APRENDIZAGEM ONLINE}

\subsection{Características}

\subsection{Rede e conhecimento}

2.2.1 Metamorfose

2.2.2 Heterogeneidade

2.2.3 Multiplicidade e de encaixe de escalas

2.2.4 Exterioridade

2.2.5 Topologia

2.2.6 Mobilidade dos centros

\subsection{Professor: o nó robusto}

2.3.1 Exercer a autoridade/praticar a tolerância

2.3.2 Mapear relevâncias/ tecer significações

2.3.3 Construir narrativas fabulosas/ mediar relações

\subsection{Cursos online como redes de aprendizagem}

\subsection{0 desafio da interação}

2.5.1 Usos do ambiente e "personalidade eletrônica"

2.6 Redes de aprendizagem online: "POIEs do Butantã" e "Comunidade de Gestores"

2.6.1 Rede de aprendizagem online "POIEs do Butantã"

Análise qualitativa e quantitativa

Constatação

2.6.2 "Comunidade de Gestores": uma rede em construção

Contextualização

Pressupostos teóricos

Diálogo

A proposta

Desafios

\subsection{Amarrando os pontos}




\section{REDES DE APRENDIZAGEM ONLINE}

Neste capítulo, apresentamos as características das redes de aprendizagem online mapeadas em nossa investigação, assim como a do professor que atua nessas redes. Para um estudo em profundidade, analisamos um agrupamento desse tipo e incorporamos um exemplo de concepção de uma rede de aprendizagem no ciberespaço.

\subsection{Características}

Redes sociais, de conhecimento, de relacionamento... Muitos são os nomes para classificar os agrupamentos do ciberespaço. Sabemos que grande parte deles reúne pessoas interessadas em novas aprendizagens, por meio da troca de informações. Pessoas que têm em comum o gosto pela pesca, por exemplo, compartilham dicas sobre a melhor isca e uso de ferramentas para capturar peixes. Os "educadores-blogueiros", da lista de discussão "Blogs Educativos", ajudam uns aos outros a respeito de como inserir em seus blogs um vídeo, como usar o computador em sala de aula, etc. A aprendizagem é um processo inerente à existência humana e pode surgir das mais diversas situações e contextos, como nas redes sociais online.

No entanto, também podemos encontrar no ciberespaço agrupamentos criados com fins educacionais, vinculados ou não a instituições educativas, mas que apresentam um objetivo educativo explícito. Nessas redes, é possível perceber que há um planejamento prévio, um ou mais responsáveis por estimular e provocar a aprendizagem do grupo, algumas discussões e atividades que visam alcançar as finalidades inicialmente expostas, e a abertura do grupo para novas proposições dos participantes ao longo do processo.

Encontramos esses elementos nas chamadas redes e comunidades virtuais de aprendizagem, agrupamentos do ciberespaço organizados para o ensino/aprendizagem. Embora essas características possam ser mapeadas em ambas, as redes e comunidades de aprendizagem se distinguem pelo fato de que a comunidade apresenta laços fortes e compromisso entre os participantes, além da colaboração mais frequiente do que nas redes.

Os elementos mapeados nos levam a perceber que, nas redes de aprendizagem online, encontramos um processo de ensino, mesmo que ele seja diferente do escolar, com relações mais horizontais, dinâmicas e fluidas - características das redes como sistema. Trata-se de ensino porque esse conceito está relacionado a um "esforço intencional e orientado de pessoas, grupos ou instituições para formar ou informar os indivíduos" (FILATRO, 2007, p. 
46). Quando o ensino alia-se à "Comunicação Mediada por Computador", temos redes de aprendizagem, segundo Harasim:

A aplicação de qualquer dessas tecnologias de Comunicação Mediada por Computador ao processo de ensino se faz por meio das redes de aprendizagem. (HARASIM et al, 2005, p. 45, grifo nosso).

No ensino, encontramos situações didáticas, ou seja, "um conjunto de circunstâncias com atividades particulares, nas quais as pessoas se encontram em determinado momento e se relacionam com outras pessoas, objetos e aspectos da realidade" (FILATRO, 2007, p. 46) nas redes de aprendizagem online, essas circunstâncias podem ser encontradas.

O processo de ensino nesses agrupamentos, no entanto, seria bastante flexível, uma vez que as redes se caracterizam pela dinamicidade e fluidez. Rigidez e autoritarismo não teriam espaço em uma rede de pessoas, já que ela dependeria do envolvimento e participação de todos para existir. Partindo desse pressuposto, o planejamento da aprendizagem visaria dar início às ações da rede, apontando alguns caminhos para que o grupo atinja seus objetivos.

A qualquer momento, os participantes poderiam influir nas propostas didáticas apresentadas e na forma como o projeto está sendo desenvolvido, apresentando sugestões. Se a maioria concordar, haveria até mesmo uma mudança de rumo, de objetivo a ser alcançado. As pessoas são a estrutura e a organização do sistema redes sociais. Se não houver participação nas decisões, não poderíamos falar em rede, mas em teia, onde há um núcleo: alguém que pensa e decide pelos demais.

Embora existam ambientes virtuais mais voltados para o desenvolvimento de redes de aprendizagem, elas podem existir por meio das mais variadas ferramentas disponíveis no ciberespaço. Uma lista de discussão, um blog, e-mails, um ambiente que agregue muitas ferramentas de comunicação e de armazenamento são meios para o desenvolvimento dessas redes e não poderiam ser considerados elementos distintivos.

Assim, as redes de aprendizagem online não se desenvolvem apenas em ambientes virtuais criados para fins educacionais. Dependendo do uso, a rede social Orkut pode abrigar uma rede ou comunidade de aprendizagem, por exemplo. As características distintivas, portanto, seriam:

\section{- o objetivo educativo explícito;}

- uma proposta inicial para a aprendizagem;

- um ou mais professores. 
Durante palestra em São Paulo, Lévy defendeu a presença do professor nas redes virtuais de aprendizagem, embora não se referisse a ele por esse nome. "Não acredito que haja uma pura espontaneidade em aprendizagens escolares. Ela precisa ser organizada. As únicas redes que funcionam sem mediador são as de entretenimento" (CARVALHO, 2007).

Outra razão para chamar os agrupamentos com as características levantadas de redes de aprendizagem online deve-se ao fato de que elas ofereceriam melhores condições para que seus participantes construam conhecimento, visto que apresentam um processo de ensino.

Para Machado (2000, p. 133), na construção de conhecimento, "sempre são necessários disciplina, ordenação, procedimentos algorítmicos, ainda que tais elementos não bastem, isoladamente ou em conjunto, para compor uma imagem dos processos cognitivos". A aprendizagem pressupõe a elaboração de conhecimento por parte do sujeito, um nível acima da simples troca de informações, do compartilhamento entre os integrantes.

No entanto, os agrupamentos do ciberespaço destinados à aprendizagem são sistemas complexos e seria pretensioso de nossa parte afirmar que todas as redes de aprendizagem online, sem exceção, possuiriam as características por nós apontadas. É necessário considerar, ainda, que o ciberespaço está em permanente construção e alteração pelas pessoas que o ocupam. O que apresentamos como elementos das redes de aprendizagem podem não ser encontrados daqui a algum tempo.

Tendo como objetivo apresentar uma distinção em relação às demais redes no ciberespaço, definiríamos as redes de aprendizagem da seguinte maneira:

\section{As redes de aprendizagem online são agrupamentos localizados no ciberespaço que apresentam características de um processo de ensino: objetivo educativo explícito, planejamento inicial e um ou mais professores entre os integrantes da rede, que só existe e se mantém se houver interação e abertura para que os participantes influenciem o processo.}

Esse entendimento foi construído a partir de revisão bibliográfica, do exame de redes e comunidades que compõem esta investigação ("Blogs Educativos", "POIEs do Butantã" e "Ensinando em Ambientes Virtuais 1") e de nossa experiência no acompanhamento de projetos educativos e colaborativos desenvolvidos no ciberespaço.

Pretendemos relacionar as redes de aprendizagem online ao que é explícito, intencional, à imagem da narrativa e do filme, em contraposição às cenas isoladas e aos fragmentos, à informação e ao tácito nas demais redes sociais. 


\subsection{Rede e conhecimento}

As redes de aprendizagem online são sistemas complexos porque assim é a relação entre as pessoas e delas com o contexto e o objeto de aprendizagem. São complexos porque há incertezas, ordem, desordem, sínteses, resistências, interferências, múltiplos significados.

Assim também é o conhecimento, uma construção que articula fragmentos, que depende de desconstrução, reconstrução, interpretação do objeto e da realidade, e exige das pessoas processos de auto-organização e reorganização mental.

Em uma época marcada pelo fenômeno rede (ROSENTHIEL, 1998) as idéias de conhecimento e de rede mostram confluências. Alguns autores, como Machado (2004), passam a adotar a metáfora do "conhecimento como rede de significações", revelando suas similaridades:

De fato, a idéia de conhecer encontra-se cada vez mais associada a conhecer o significado, sendo o significado de algo caracterizado por meio das relações que podem ser estabelecidas entre esse algo e o resto do mundo. Construir conhecimento seria, pois, construir uma grande rede de significações, em que os nós seriam os conceitos, as noções, as idéias, em outras palavras, os significados; e os fios que compõem os nós seriam as relações que estabelecemos entre algo em que concentramos nossa atenção e as demais idéias, noções ou conceitos; tais relações condensam-se em feixes, que, por sua vez, se articulam em uma grande rede. (MACHADO, 2004, p. 89).

Para detalhar essa imagem, Machado (2000, 2005) transporta as características do hipertexto ${ }^{25}$ assinaladas por Lévy, para quem "o hipertexto é talvez uma metáfora válida para todas as esferas da realidade em que significações estejam em jogo" (1993, p. 25). As características são: metamorfose, heterogeneidade, multiplicidade e de encaixe das escalas, exterioridade, topologia e mobilidade dos centros (LÉVY, 1993).

Esses princípios não só contribuem para explorarmos a idéia de conhecimento como rede de significações, mas também para apontarmos algumas dinâmicas que ocorrem nas redes de aprendizagem online. Embora elas não se apresentem apenas nesse tipo de rede, sendo aplicável às demais do ciberespaço, a idéia é mostrar similaridades entre o hipertexto, o conhecimento e as redes virtuais de aprendizagem.

A seguir, reproduzimos os princípios de Lévy (1993) e a reflexões de Machado (2004) e apresentamos as inter-relações que estabelecemos com as redes de aprendizagem online.

\footnotetext{
25 "Uma forma não-linear de apresentar e consultar informações. Um hipertexto vincula as informações contidas em seus documentos (ou 'hiperdocumentos', como preferem alguns) criando uma rede de associações complexas através de hyperlinks ou, mais simplesmente, links" (COSTA, 1999, p. 254).
} 


\subsubsection{Metamorfose}

A rede hipertextual está em constante construção e renegociação. Ela pode permanecer estável durante certo tempo, mas esta estabilidade é em si mesma fruto de um trabalho. Sua extensão, sua composição e seu desenho estão permanentemente em jogo para os atores envolvidos, sejam eles humanos, palavras, imagens, traços de imagens ou de contexto, objetos técnicos, componentes destes objetos, etc. (LÉVY, 1993, p. 25, grifo nosso).

\section{$\underline{\mathrm{O} \text { conhecimento como rede }}$}

Um significado nunca está definitivamente construído. O feixe de relações que o constitui transforma-se continuamente, incorporando novas relações ou depurandose de outras, que se tornam menos expressivas (MACHADO, 2000, p. 132).

\section{$\underline{\text { As redes de aprendizagem online }}$}

Os participantes de uma rede de aprendizagem online estão permanentemente em negociação, sem a qual não seria possível conviver e aprender com os demais. A estabilidade seria fruto das negociações e das dinâmicas da rede para manter e/ou acolher novos integrantes.

Além disso, nas redes de aprendizagem online, cada contribuição compartilhada pode transformar o sentido e o entendimento do outro, apresentando relações que contribuam para o conhecimento que está em construção. A estabilidade, assinalada por Lévy, poderia ser pensada nessas redes como os significados construídos coletivamente, o entendimento compartilhado.

\subsubsection{Heterogeneidade}

Os nós e as conexões de uma rede hipertextual são heterogêneos. Na memória serão encontradas imagens, sons, palavras, diversas sensações, modelos etc, e as conexões serão lógicas, afetivas, etc. $\mathrm{Na}$ comunicação, as mensagens serão multimídias, multimodais, analógicas, digitais, etc. O processo sociotécnico colocará em jogo pessoas, grupos, artefatos, forças naturais de todos os tamanhos, com todos os tipos de associações que pudermos imaginar entre esses elementos. (LÉVY, 1993, p. 25).

\section{$\underline{\text { O conhecimento como rede }}$}

A multiplicidade de fios de interligação - sons, palavras, imagens, combinações pluridimensionais de tais elementos - conformando-se em relações lógicas, analógicas, afetivas, sensoriais, ou complexos de tais elementos, ressalta o quanto parece vã a expectativa da construção do conhecimento apenas pelos canais lingüístico e lógico matemático, como bem registrou Gardner em "Multiple Intelligences" (1993). (MACHADO, 1005, p. 146). 
$\underline{\text { As redes de aprendizagem online }}$

O ciberespaço oferece às redes de aprendizagem possibilidades de trabalhar com diversos formatos: imagens, sons, vídeos, entre outros, reunindo-os em um só lugar, embora as interações entre os participantes, elemento fundamental de uma rede online, aconteça, basicamente, pela palavra digitada.

A heterogeneidade também pode ser relacionada às pessoas que compõem a rede de aprendizagem. Cada nó seria representado por uma pessoa diferente e única. A singularidade de cada integrante torna a rede rica em diversidade, contribuindo com a aprendizagem para além do objetivo explícito.

\subsubsection{Multiplicidade e de encaixe de escalas}

O hipertexto se organiza de modo "fractal", ou seja, qualquer nó ou conexão, quando analisado, pode revelar-se como sendo composto por toda uma rede, e assim por diante, indefinidamente, ao longo da escala dos graus de precisão. Em algumas circunstancias críticas, há efeitos que podem propagar-se de uma escala a outra: a interpretação de uma vírgula em um texto (elemento de uma microrrede de documentos), caso se trate de um tratado internacional, pode repercutir na vida de milhões de pessoas (na escala da macrorrede social). (LÉVY, 1993, p. 25).

\section{$\underline{\mathrm{O} \text { conhecimento como rede }}$}

A organização da rede/hipertexto de modo "fractal" possibilita a compreensão da sensação de proximidade entre concepções como as de Aebli, Ullman ou Luria no que se refere à construção do significado dos conceitos e recentes 'insights' de Lévy. De fato, a mesma dinâmica dos campos semânticos ou associativos, concebida pelos primeiros no nível das palavras, poderia ser estendida para o universo de significações, de que o hipertexto é uma metáfora, com a ressalva de que os canais não-verbais talvez tenham sido subestimados. (MACHADO, 2005, p. 147).

\section{$\underline{\text { As redes de aprendizagem online }}$}

Podemos pensar os nós a que Lévy se refere como as "falas" dos participantes na rede. Cada uma delas pode ser uma porta de entrada para debates e novos significados. Além disso, os conteúdos elaborados pelos participantes de uma rede de aprendizagem online, se permitidos para visualização de qualquer pessoa no ciberespaço, podem contribuir para aprendizagem de quem acessá-la - o que poderíamos entender como um efeito de propagação. 
Citamos, como exemplo, o COLEARN ${ }^{26}$ - Comunidade de Pesquisa sobre Aprendizagem

Colaborativa e Tecnologias -, cujo conteúdo pode ser acessado por qualquer internauta.

\subsubsection{Exterioridade}

A rede não possui unidade orgânica, nem motor interno. Seu crescimento e sua diminuição, sua composição e sua recomposição permanente dependem de um exterior indeterminado: adição de novos elementos, conexões com outras redes, excitação de elementos terminais (captadores), etc. Por exemplo, para a rede semântica de uma pessoa escutando um discurso, a dinâmica dos estados de ativação resulta de uma fonte externa de palavras e imagens. Na constituição da rede sociotécnica intervêm o tempo todo elementos novos que não lhe pertenciam no instante anterior: elétrons, micróbios, raios X, macromoléculas, etc. (LÉVY, 1993, p.26).

\section{$\underline{\mathrm{O} \text { conhecimento como rede }}$}

No caso da transposição para o conhecimento institucionalizado, o Princípio da exterioridade põe em evidência o fato de que distinções entre conhecimento escolar e conhecimento teórico, ou entre senso comum e conhecimento científico precisam ser tão relativizadas que talvez nem subsistam. (MACHADO, 2005, p. 148).

\section{$\underline{\text { As redes de aprendizagem online }}$}

O princípio de exterioridade transporta-nos para o fato de que as redes de aprendizagem online podem crescer ou diminuir em número de participantes com muita rapidez. Há redes de aprendizagem, como a "Gestores de Comunidades Virtuais", que trataremos neste capítulo, que eram abertas e aceitavam participantes a qualquer momento.

A cada novo integrante, novas contribuições, caracterizando o conhecimento em construção. Outras redes, como cursos de graduação oferecidos a distância, têm um número limite e ainda podem diminuir com o abandono de alguns participantes. A marca de volatilidade da rede de aprendizagem online está intrinsecamente ligada à manutenção do interesse pela aprendizagem, assim como o seu despertar (no caso do ingresso).

\footnotetext{
${ }^{26}$ Disponível em http://labspace.open.ac.uk/course/view.php?id=1456. Acesso em 10 jul. 2008
} 


\title{
2.2.5 Topologia
}

Nos hipertextos, tudo funciona por proximidade, por vizinhança. Neles, o curso dos acontecimentos é uma questão de topologia, de caminhos. Não há espaço universal homogêneo onde haja forças de ligação e separação, onde as mensagens poderiam circular livremente. Tudo que se desloca deve utilizar-se da rede hipertextual tal como ela se encontra, ou então será obrigado a modificá-la. A rede não está no espaço, ela é o espaço. (LÉVY, 1993, p. 26).

\section{$\underline{\mathrm{O} \text { conhecimento como rede }}$}

O que está em foco no Princípio de topologia é a idéia de proximidade entre significações, que não poderia ser considerada do ponto de vista da geometria clássica, mas sim no âmbito da topologia: há distâncias e distâncias (...). Correspondentemente, ao tratar-se dos percursos sobre a rede, no dia-a-dia ou em atividades pedagógicas, a abertura propiciada pela concepção topológica deve prevalecer. (MACHADO, 2005, p. 148).

As redes de aprendizagem online

Quanto menor a distância entre os participantes de uma rede de aprendizagem online, maior as chances de construção de conhecimento, uma vez que na aprendizagem em rede online não bastam informações, mas também relações de proximidade, que envolvam atenção, companheirismo, afeto. A significação, principalmente em meio virtual, onde nem sempre é possível ver expressões faciais, passa pelos sentimentos, manifestados, por exemplo, por meio de emoticons ${ }^{27}$.

\subsubsection{Mobilidade dos centros}

\begin{abstract}
A rede não tem centro, ou melhor, possui permanentemente diversos centros que são como pontas luminosas perpetuamente móveis, saltando de um nó ao outro, trazendo ao redor de si uma ramificação infinita de pequenas raízes, de rizomas, finas linhas brancas esboçando por um instante um mapa qualquer com detalhes delicados, e depois correndo para desenhar mais à frente outras paisagens de sentido. (LÉVY, 1993, p. 26).
\end{abstract}

\footnotetext{
27 “Forma de comunicação paralingüística, um “emoticon”, palavra derivada de emotion (emoção) + icon (ícone) (em alguns casos chamado smiley) é uma seqüência de caracteres tipográficos, tais como: :), ou ^^^^e :-); ou, também, uma imagem (usualmente, pequena), que traduzem ou querem transmitir o estado psicológico, emotivo, de quem os emprega, por meio de ícones ilustrativos de uma expressão facial. Exemplos: (i.e. sorrindo, estou alegre); $\because$ (triste, chorando), etc.” Disponível em http://pt.wikipedia.org/wiki/Emoticon acesso em 10 jul. 2008
} 
$\underline{\mathrm{O} \text { conhecimento como rede }}$

[...] a rede de significados não tem centro, tem múltiplos centros... de interesse. (MACHADO, 2000, p. 131).

\section{$\underline{\text { As redes de aprendizagem online }}$}

Cada participante da rede é um centro e todos eles são fundamentais para o conhecimento dos outros integrantes, uma vez que a aprendizagem em rede baseia-se na interação. A atenção dada a cada centro pode variar ao longo do processo uma vez que as pessoas são mais do que "alguém" na rede: ao se manifestarem diante do grupo também representam conteúdos/idéias a serem discutidos.

Ainda quanto à mobilidade dos centros, seria interessante pensarmos também que uma rede de aprendizagem online pode ser a porta de entrada para a Internet. E, nesse sentido, ela integra o desenho "contra-hegemônico" do ciberespaço; "contra-hegemônico porque cada um entra e configura a rede como bem entender", segundo Bento Silva, que concedeu entrevista a esta pesquisadora (CARVALHO, 2008a).

Bento Silva explicou que a página da escola, do professor e/ou do aluno pode ser o centro do ciberespaço, à medida que as pessoas utilizam essas páginas para nele entrarem. "Se na Internet a escola tem um bom projeto, um bom site ${ }^{28}$, neste site tem materiais e projetos atrativos, essa escola pode assumir a centralidade. Essa escola pode ser desejada, visitada, partilhada por pessoas de qualquer parte do mundo" (CARVALHO, 2008a). Por isso é que se fala cada vez mais de "redes localizadas", o "cruzamento do local com o global".

Para Bento Silva, por mais distante que uma escola possa estar - em relação à sua situação territorial física -, e apresente um potencial de ação reduzido, "na rede, o limite é infinito, no limite e interesse de seus projetos". A possibilidade de ser o nó, o centro do ciberespaço, valoriza o trabalho do professor, do aluno e da escola.

\footnotetext{
${ }^{28}$ Site é "Um conjunto de páginas da Web que façam parte de um mesmo URL ou 'endereço'. A idéia de site está relacionada à idéia de 'local', o que na verdade é um tópico complexo em se tratando de um espaço virtual criado por uma rede distribuída que lida com hiperdocumentos. Creio que a maneira mais simples de entender 'site' é pensar que um site corresponde a um hiperdocumento, com todas as suas imagens, vínculos e referências, mesmo que esse hiperdocumento possa ter, potencialmente, o tamanho e a complexidade de uma grande enciclopédia” (COSTA, 1999, p. 258).
} 


\subsection{Professor: o nó robusto}

Nas redes sociais online, as pessoas são os nós, e os fios são as relações entre elas. As redes não possuem núcleo - senão seriam teias - e dependem de todos os nós para não apresentarem buracos e se desfazerem.

No entanto, alguns deses nós apresentam um número maior de ligações. Em Recuero (2005), vimos que essa dinâmica chama-se clusterização - nós extremamente conectados - e se manifesta por meio de pessoas com mais conexões do que a média do grupo.

Durante esta investigação, encontramos algumas pessoas nas redes de aprendizagem analisadas que não só teriam um número grande de ligações, como seriam nós robustos - em sentido metafórico - graças a algumas competências que possuem. Referimo-nos àqueles que são conhecidos como professores, cujas competências nas redes online seriam as mesmas, mas reconfiguradas no ciberespaço.

No espaço virtual, o professor possui diversos nomes: educador, tutor, mediador, gestor, etc. Para essas nomenclaturas, alguns autores atrelam especificidades, mas nesta pesquisa, adotamos o termo "professor" porque a história the atribuiria competências mais abrangentes, englobando as diversas ações atreladas às nomenclaturas que apareceram depois.

O professor a que nos referimos aqui não está restrito ao universo escolar, nem apenas ligado a instituições de ensino. Afinal, existe professor de capoeira, de futebol, de dança, entre outros, que nem sempre possuem vínculo com o ensino formal.

Sabemos que nas redes de aprendizagem online as pessoas ensinam e aprendem umas com as outras - até porque tratamos de rede de pessoas em um processo educativo. Mas, entre elas, destaca-se quem possui a capacidade de "tecer significações", “mediar relações", “mapear relevâncias", "construir narrativas fabulosas", "praticar a tolerância" e “exercer a autoridade”. Essas são competências apontadas por Machado (2004, 2009) ao professor que concebe o conhecimento como uma rede de significações, e não como algo a ser dado ao outro (que não sabe) ou decomposto em partes simples para ser apresentado em uma seqüência lógica.

As competências são atribuídas ao professor que atua tanto no ciberespaço como fora dele. Mas sabemos que nem todos as possuem e, muitas vezes, o que encontramos é apenas a repetição de uma prática educativa transmissora de conteúdos, que não condiz com a idéia de rede de aprendizagem, seja ela desenvolvida no ciberespaço ou não.

As seis competências básicas podem constituir três eixos, em pares complementares: tecer significações/mapear relevâncias, mediar relações/construir narrativas fabulosas, 
exercer a autoridade/praticar a tolerância (MACHADO, 2009). A organização em feixes refere-se à posição do professor em relação aos demais participantes. Em alguns momentos, o professor estabelece uma relação simétrica com os integrantes da rede, mas, em outros, precisa estar assimetricamente para ajudar a rede a avançar. Três desses verbos representam ações simétricas, niveladas: tolerar, mediar e tecer; os outros, a assimetria necessária em um processo educativo: exercer autoridade, fabular e mapear.

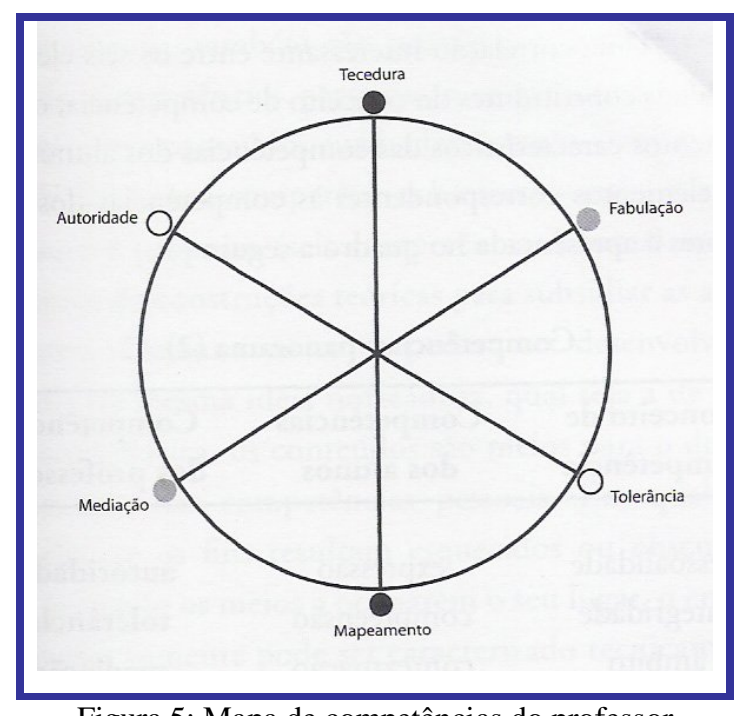

Figura 5: Mapa de competências do professor Fonte: MACHADO, 2009, p. 81.

\subsubsection{Exercer a autoridade/praticar a tolerância}

Em uma rede de aprendizagem online, o professor se destaca por sua autoridade diante do grupo, atribuída aos conhecimentos que possui a respeito do objeto de aprendizagem e da responsabilidade que toma para si acerca do processo de ensino a ser desenvolvido.

O professor lembra-nos a autoridade encontrada na cultura "tecnomeritocrática", primeira camada de confecção do ciberespaço, vista no capítulo 1. Naquele contexto, a autoridade estava enraizada na academia e na ciência, coordenava projetos e contava com a confiança dos demais. O respeito à autoridade demandava de seu comportamento, que estava de acordo com as normas da comunidade/rede e do valor de compartilhamento de seus conhecimentos com os demais. Em outra camada do ciberespaço, a de algumas comunidades da cultura hacker, a presença dessa autoridade também era encontrada, embora os agrupamentos fossem mais auto-organizados por não terem vínculo institucional. 
O professor das redes de aprendizagem online revela cerca semelhança com essas autoridades que contribuíram para a construção do ciberespaço. Entre os participantes da rede, ele se faz presente para acalorar, alimentar e orientar o grupo.

Mas sua autoridade não pode ser exercida sem tolerância. Ela, por sua vez, advém dele justamente por ser autoridade, ou seja, apenas uma autoridade pode ser ou não tolerante. Não faria sentido tolerar algo que está fora do alcance da atuação (MACHADO, 2009). A competência do professor revela-se pela consciência da necessidade de respeito pelos outros, uma prática essencialmente educativa. Com a suavidade da lua, ele aproveita as diferenças entre os participantes da rede para expandir a compreensão sobre o objeto e a relação entre os próprios integrantes, ajudando o grupo a crescer. Ao colocar-se em simetria com os participantes, equilibra a relação na qual também precisa exercer a autoridade.

\subsubsection{Mapear relevâncias/ tecer significações}

As redes de aprendizagem online existem e se sustentam graças às interações entre seus membros. Elas permitem aos integrantes trocarem informações que podem levá-los também com a contribuição de conteúdos disponibilizados no ambiente onde se encontram - a construírem uma visão do que está sendo tratado, empregando-a em outras situações dentro ou fora do ciberespaço.

As interações, no entanto, geram um volume grande de informações e todas elas se relacionam. No emaranhado de significados criados pela rede, o professor age como um mapeador de relevâncias, a partir do objetivo a que o agrupamento se propôs. "É certo que tudo pode ser relacionado a quase tudo, mas discernir o que verdadeiramente importa é, cada vez mais, a grande questão", diz Machado (2004, p. 92), para quem as noções de rede e mapa nunca estiveram tão umbilicalmente ligadas. Para não se perder na rede, o navegador utilizase de um mapa de relevâncias.

Nesse contexto, o professor toma para si a responsabilidade de apontar e estimular a exploração de centros de interesse que estão de acordo com a proposta educativa. Ele também organiza atividades e apresenta um planejamento inicial, sempre em concordância com os participantes. Ao mapear relevâncias, coloca-se em assimetria diante dos demais.

Por outro lado, o professor está ao lado dos participantes o tempo todo para reconfigurar e expandir a rede de significados de cada um. Ele entende o conhecimento como rede de significações, onde os nós são os conceitos, as idéias; e os fios que compõem os nós são as relações estabelecidas entre as noções (MACHADO, 2004). Colocando-se em simetria 
perante os demais integrantes, o professor comunica-se, sem coação. Ao dar a palavra ao outro, aproveita para ajudá-los a refinar e atualizar a rede de significados que possuem antes mesmo de fazer parte do grupo.

\subsubsection{Construir narrativas fabulosas/ mediar relações}

Se ampliarmos com uma lente as ações do professor sobre a rede de aprendizagem online, veremos que elas acabam por construir uma narrativa cujo final seria alcançar o objetivo educativo definido no início da narração. O professor/narrador contribui para que os participantes não se percam na fragmentação que caracteriza o ciberespaço.

Mas a narrativa é construída em conjunto, embora o professor tome a dianteira da ação. E o faz por ser um mediador de relações relevantes. Nem sempre as pessoas conseguem vislumbrar relações entre os significados que são fundamentais para o conhecimento. $\mathrm{O}$ professor atua, então, para destacar e até mesmo apresentar essas relações, negociando com os outros a sua relevância. Coloca-se na perspectiva do outro para levar em conta seus pontos de vista e ajudá-lo a construir conhecimento. Ao mediar, está no mesmo nível dos demais participantes, intervindo com suavidade.

Ao apresentar as seis competências anteriores, o professor se destaca na rede de aprendizagem online por ser um nó robusto, capaz de estabelecer um número grande de ligações com os demais participantes, não os deixando se perder e nem se sentirem perdidos em meio aos outros nós. Apresenta-se como um facilitador da aprendizagem, alguém que enxerga o todo e promove oportunidades para que aos participantes.

De modo algum a presença do professor retira dos demais a responsabilidade pela própria aprendizagem e a dos colegas. Em rede, construir conhecimento está intrinsecamente relacionado à interação, além do estudo de conteúdos disponibilizados no ambiente, não apenas pelo professor, mas por todos. Trata-se, portanto, de uma relação mais horizontal, mas que não prescinde de assimetria em alguns momentos por visar a um objetivo educativo.

Há de se considerar, ainda, que para tolerar/exercer autoridade, mediar/fabular e tecer/mapear no ciberespaço, o professor precisa compreender as particularidades técnicas e culturais em transformação. Sua ação a partir dessas competências depende de enxergar o ciberespaço para além do uso instrumental, do emprego de novas ferramentas para animar o processo educacional, sem reconfigurá-lo. Seria preciso apropriar-se do ciberespaço a partir 
de uma perspectiva cultural, entendendo as transformações educacionais que se desenvolvem junto com ele.

A articulação entre a cultura digital e a educação se concretiza a partir das possibilidades de organização em rede, apropriação criativa dos meios tecnológicos de produção de informação, acompanhado de um forte repensar dos valores, práticas e modos de ser, pensar e agir da sociedade, o que implica na efetiva possibilidade de transformação social. (PRETTO; ASSIS, 2008, p. 82, grifo nosso).

A ação do professor no ciberespaço está diretamente relacionada ao caráter de autoria que a profissão demanda. Ele não deve ser apenas um ator no ciberespaço, mas também um autor, junto com os participantes da rede de aprendizagem. Para Pretto (2007), os professores precisam recuperar a perspectiva artesã de seu trabalho, com auxílio de políticas públicas.

Se na escola o professor é criativo e desenvolve trabalhos interessantes com seus alunos, utiliza-se de vários recursos como vídeo, computador, gravador, e age como mediador da aprendizagem, concebendo o conhecimento como tratamos aqui, vai encontrar no ciberespaço o seu lugar. "O online potencializa esta energia que o professor já tem”, disse Marco Silva em entrevista a esta pesquisadora (CARVALHO, 2008b).

Ao conhecer as ferramentas e recursos do ciberespaço, o professor desenvolverá formas de utilizá-los no ensino para promover a aprendizagem de forma interativa, em rede, da mesma forma que saberá explorar a oportunidade que o ciberespaço oferece de um relacionamento mais personalizado com seus alunos, quando for necessário.

Mas se o professor é adepto ao ensino "baseado na oratória de um para muitos", ficaria difícil desenvolver um trabalho dialógico, que contemple debate e colaboração em ambiente online. Marco Silva (CARVALHO, 2008b) acredita que esse professor acabaria subutilizando os recursos que a Internet disponibiliza, por exemplo, apenas postando textos para leitura e pedindo respostas aos alunos.

Nesse caso, migra-se para o virtual, diz, "mas levando um ranço, baseado no texto chapado e nas respostas a perguntas feitas, quando o online é extremamente rico, é vivo, permite convergência de mídias [...]. Para o professor não subutilizar o ambiente virtual, é preciso que antes saiba o que é ser um docente" (CARVALHO, 2008b). O docente das redes de aprendizagem online é o profissional que possui as competências destacadas neste capítulo e, por meio de sua autoria, promove a aprendizagem colaborativa. 


\subsection{Cursos online como redes de aprendizagem}

Durante nossa trajetória de pesquisa, perguntamo-nos qual a relação entre redes de aprendizagem e cursos online. Mais ainda, se as redes de aprendizagem pertenciam ao universo da Educação a Distância. Para responder a essas questões, buscamos alguns conceitos e orientações, como a do Ministério da Educação:

[...] educação a distância deve ser compreendida como a atividade pedagógica que é caracterizada por um processo de ensino-aprendizagem realizado com mediação docente e a utilização de recursos didáticos sistematicamente organizados, apresentados em diferentes suportes tecnológicos de informação e comunicação, os quais podem ser utilizados de forma isolada ou combinadamente, sem a freqüência obrigatória de alunos e professores. (MINISTÉRIO DA EDUCAÇÃO, 2002).

O traço distintivo dessa modalidade de Educação seria a midiatização das relações entre professores e alunos, substituindo a assistência regular à aula por uma nova proposta, na qual o tempo e o espaço não são necessariamente compartilhados (LITWIN, 2001).

As Tecnologias de Informação e Comunicação (TICs), assim como apostilas impressas, programas de TV e gravações em áudio, são algumas das tecnologias incorporadas à Educação a Distância como suporte e tornam-se grandes desafios nos anos 90 para a modalidade. Há quem diga, no entanto, que elas resolvem o problema da falta de interatividade a que a $\mathrm{EaD}$ se ressentia.

No ciberespaço, a troca de opiniões e a orientação do docente são rápidas, podendo ser mais claras e fáceis do que via papel e correios. O acesso e as informações constantemente atualizados surgem como valor agregado a essa modalidade de ensino que pode ser desenvolvida por meio das redes de aprendizagem online caso haja interação entre os participantes, planejamento inicial, um ou mais professores e o objetivo educativo explícito, características levantadas nesta pesquisa.

A interação entre alunos e professores é ressaltada como "um dos pilares para garantir a qualidade de um curso a distância" no relatório final da "Comissão Assessora para a Educação Superior” (MINISTÉRIO DA EDUCAÇÃO, 2002, p. 14).

O relatório destaca o papel das TICs "para atender às exigências de qualidade do processo pedagógico atual [...]", devendo ser "oferecidas e contempladas, prioritariamente, as condições de telecomunicação (telefone, fax, correio eletrônico, teleconferência, fórum de 
debate em rede, etc...) e interação que permitam uma maior integração entre professores e alunos", assim como entre os estudantes.

Apesar de conhecida a importância da interação para o processo de ensino e aprendizagem, Valente $(2003$, 1999) detecta na Educação a Distância via Internet a existência de diferentes abordagens: a broadcast, a virtualização da sala de aula tradicional e o estar “junto virtual”. O que as diferencia é o grau de interação entre professores e alunos:

- A abordagem broadcast: a informação é enviada ao aluno pela Internet, mas não existe interação entre eles. Trata-se de uma relação "um para todos", na qual é difícil saber se o aluno transformou a informação em conhecimento.

- A virtualização da escola tradicional: há um pouco de interação: o professor passa uma atividade, o aluno a faz e devolve ao professor para avaliação. Neste caso, a interação resume-se em "fazer uma pergunta e receber uma resposta. Certamente, isso é insuficiente para entender se o aprendiz foi capaz de atribuir significado à informação disponível" (VALENTE, 2003, p. 31).

- O “estar junto virtual”: há múltiplas interações para acompanhar e assessorar permanentemente o aluno, propondo desafios que o "auxiliem a atribuir significado ao que está desenvolvendo. Essas interações criam meios para o aprendiz aplicar, transformar e buscar outras informações e, assim, construir novos conhecimentos" (VALENTE, 2003, p. 31). Esta abordagem, portanto, não tem como objetivo só tornar a informação disponível e verificar se o aluno aprendeu.

Embora o ciberespaço tenha condições de oferecer uma Educação a Distância que valoriza o "estar junto virtual", ainda podemos encontrar cursos online que "virtualizam a escola tradicional" e oferecem uma "abordagem broadcasting", restringindo o potencial interativo entre professores e alunos, e entre os estudantes.

Parte da responsabilidade poderia ser atribuída a alguns ambientes virtuais desenvolvidos para a Educação, que reproduzem as paredes das salas de aula presenciais ao se mostrarem pouco flexíveis (e inflexíveis), apresentando apenas espaços para serem preenchidos. No entanto, um bom professor seria capaz de burlar as dificuldades impostas pela tecnologia ${ }^{29}$, encontrando meios para promover a interação.

Independente da abordagem, quando esses cursos utilizam a conexão em rede, poderíamos falar em Educação online, nova expressão que seria mais adequada do que Educação a Distância (EaD), essa mais abrangente.

Educação online é uma ação sistemática de uso de tecnologias, abrangendo hipertexto e redes de comunicação interativa, para distribuição de conteúdo educacional e promoção da aprendizagem, sem limitação de tempo ou lugar (anytime, anyplace). Sua principal característica é a mediação tecnológica pela conexão em rede. (FILATRO, 2007, p. 47, grifo nosso).

\footnotetext{
${ }^{29}$ Opinião do Professor Marcos Silva, da UFRJ, expressa durante o II Simpósio Nacional da ABCiber, realizado na PUC-SP. Sua opinião foi corroborada pelos pesquisadores presentes, como eu, em debate ocorrido no Painel Temático 4 "Educação na Cibercultura II: Dialogia e Dicotomia na rede”, em 11 de novembro de 2008.
} 
Educação online, portanto, se diferencia da Educação a Distância por depender "exclusivamente da comunicação online" (FILATRO, 2007, p. 48).

A autora também contribui para distinguir a Educação online do chamado " $e$ learning”, “cuja mediação eletrônica pode ou não incluir conexão de rede” (2007, p. 48); como exemplo, os pacotes multimídia para uso individual que independe de conexão em rede.

Assim como os cursos, poderíamos incluir as redes de aprendizagem desenvolvidas no ciberespaço ao universo da Educação online, uma vez que ambas apresentam um processo de ensino com mediação pedagógica pela conexão em rede.

Os cursos online poderiam ser chamados de redes de aprendizagem quando estimularem a interação entre professores e alunos e entre os estudantes, estando aberto a propostas dos participantes.

Há cursos com propostas mais abertas são redes de aprendizagens. O professor cria alguns materiais, atividades, questões e os alunos se organizam na escolha dos tópicos, dos materiais, das pesquisas, da produção. São cursos mais centrados na colaboração dos alunos do que no professor e pressupõem alunos com muita maturidade, motivação e capacidade de aprender juntos. Em geral são para um número relativamente pequeno de alunos (MORAN, 2008, grifo do autor).

Mas, no ciberespaço, é possível encontrar cursos que não funcionam na estrutura de rede; ao não apresentarem dinamismo e fluidez, não poderiam ser chamados de redes de aprendizagem. Empresas que oferecem treinamentos e atualizações a seus funcionários, por exemplo, nem sempre privilegiam a interação e alcançam os objetivos definidos previamente. O que se pretende aqui não é atribuir valor, mas apontar que há diferenças na dinâmica educacional encontrada no ciberespaço.

\subsection{O desafio da interação}

Nossa experiência no acompanhamento de redes de aprendizagem desenvolvidas no Portal EducaRede ${ }^{30}$, a revisão de literatura e a análise de uma rede e de uma comunidade

\footnotetext{
${ }^{30}$ O Portal EducaRede é uma iniciativa da Fundação Telefônica e existe em alguns países onde o Grupo Telefônica atua. No Brasil, o portal, em parceria com a Fundação Carlos Alberto Vanzolini, é desenvolvido pelo Centro de Estudos e Pesquisas em Educação, Cultura e Ação Comunitária (Cenpec), ONG para a qual esta pesquisadora trabalhava antes e durante a realização desta dissertação. O objetivo do Portal é estimular o uso pedagógico da Internet e apoiar as ações do Programa EducaRede, como os projetos desenvolvidos em comunidades virtuais de aprendizagem junto com o Poder Público.
} 
virtual de aprendizagem para esta dissertação indicam que não é fácil encontrar interação a partir de uma proposta de aprendizagem online. Muitas vezes, alguém ou uma instituição deseja dar início a uma rede, mas não consegue levá-la adiante porque não há diálogo, muito menos colaboração.

Pode parecer contraditório, mas a interação em uma rede de aprendizagem já pode ser considerada uma vitória em se tratando de Educação online. Presenciar a colaboração entre os membros seria o ideal, embora ainda mais difícil. A explicação para essas dificuldades consistiria, principalmente, na ausência de uma cultura de aprendizagem no ciberespaço entre a maioria dos alunos, e de ensino, entre grande parte dos educadores. Há, ainda, a pouca familiaridade de ambos com ferramentas interativas e os problemas técnicos que os participantes enfrentam durante um processo de ensino.

Lembremos que esta dissertação trata de redes de pessoas. Tanto uma rede social quanto uma rede de aprendizagem não poderiam existir se não houver interação de seus membros. As interações são a base para a estrutura, a organização e a dinâmica do "sistema" rede social, como vimos anteriormente.

Mas como entender interação? Ao definirmos rede social, assumimos como interação a ação entre duas ou mais pessoas, uma vez que "inter" é um prefixo à palavra "ação". Ação, por sua vez, é um fazer consciente, significado, é a "característica mais fundamental do modo de ser do ser humano" (ARENDT apud MACHADO, 2004, p. 153).

Primo (2003) estabelece uma dicotomia para tratar da interação mediada por computador. Seriam duas as formas: a interação mútua, "caracterizada por relações interdependentes e processos de negociação, em que cada interagente participa da construção inventiva e cooperada da relação, afetando-se mutuamente" e a interação reativa, "limitada por relações determinísticas de estímulo e resposta" (RECUERO, 2005, p. 6).

Como Primo, outros autores tratam de interação não se restringindo à relação entre pessoas, mas também entre pessoas e computadores, vídeos, imagens, sons e tudo mais que pode ser encontrado no ciberespaço. Verificamos, ainda, que o termo interação se mistura à interatividade quando empregada na área de informática.

Multigner (1994 apud SILVA, 2002, p. 93) explica que o “conceito de 'interação’ vem da física, foi incorporada pela Sociologia, pela Psicologia Social e finalmente, no campo da Informática, transmuta-se em "interatividade", revelando que "interação" não só pode variar de acordo com o campo de conhecimento, como também pode migrar para "interatividade", no campo da Informática, apresentando algumas especificidades. 
Tinland (apud SILVA, p. 93) complementaria essa citação ao expressar uma distinção, na qual a interatividade designa mais do que as "interações sobre as quais repousa a estabilidade do mundo físico ou biológico, etc. [...]). Ela abre uma dinâmica espiralada ao desenvolvimento do imprevisível e indefinitivamente aberto. É uma criação aberta, uma criação comum aos participantes". Particularmente, acreditamos que interação - pensando aqui na relação entre pessoas - também contemplaria os elementos "imprevisível", "aberto" e “criação comum aos participantes”, não sendo estes restritos à interatividade.

Os autores são citados por Silva (2002) que fez um amplo levantamento da literatura a respeito do tema e o explora a partir da interdisciplinaridade e do pensamento complexo. "O termo interatividade foi posto em destaque com o fim de especificar um tipo singular de interação". Mas por que interação teria se transmutado em interatividade no campo da informática? - pergunta-se Silva, que responde: "Talvez para garantir ao termo 'interatividade' singularidades dispersas no vasto conceito de interação. Talvez a necessidade de lhe conferir aspectos novos ausentes em todas as acepções do termo 'interação'” (2002, p. 100).

Assim, vemos que o campo semântico de "interação" e sua aplicabilidade são muito abrangentes. Não temos condições aqui de aprofundar essas abordagens - nosso objetivo foi apontar outras interpretações e a complexidade do tema.

O nosso entendimento é de que interação só é possível entre pessoas porque ação é uma característica do ser humano, um fazer significado, que pressupõe uma antecipação sobre suas conseqüências, mesmo considerando as especificidades do ambiente virtual.

Em rede online, a interação revela-se, principalmente, pela troca de mensagens entre os participantes em ambiente virtual, pela "presença" manifestada, expressa por meio da linguagem, visível aos olhos de todos. Sabemos que muitas pessoas entram em um ambiente virtual, vêem tudo, mas não contribuem com mensagens. A importância dessas publicações deve-se ao fato de que é por meio delas que a ação de outras pessoas podem ser desencadeadas, em um processo de "inter-ação".

Se não há manifestação, como haver interação? Quem só observa e, individualmente, absorve os conteúdos publicados, sem contribuir por meio da linguagem, está interagindo?

Essa é uma questão polêmica; mas consideramos que o processo de interação, em ambiente virtual, só seria possível por meio da troca entre os participantes da rede. Para que haja "inter-ação" seria preciso a ação manifestada das pessoas, para que elas se relacionem. O processo de aprendizagem em rede dependeria mais da interação dos participantes do que do contato deles com os conteúdos disponibilizados. 
Não poderíamos dizer que os "silenciosos" - entendidos como os que não interagem não fazem parte da rede nem aprendem por meio dela. Nas redes e comunidades de aprendizagem que acompanhamos, quase sempre há um integrante que se manifesta pontualmente e/ou quando o fim da interação se aproxima, expressando ter acompanhado as trocas realizadas entre os demais. Além disso, para citar um exemplo fora do ciberespaço, podemos aprender muito com a leitura de um livro sem que seja necessário nos manifestarmos a outras pessoas. $\mathrm{O}$ mesmo aconteceria em ambiente virtual.

Outra forma de considerar que os "silenciosos" - os que não interagem com os demais - fazem parte da rede seria enxergá-los como "nós" da rede. Poderíamos pensar em deslocamentos dos pontos de interação durante sua existência. Dificilmente todos interagem o tempo todo, mas, em rede, sempre haveria pessoas interagindo. As interações manteriam o sistema rede e compensariam a "ausência" dos silenciosos, em um movimento de alternância das vozes para sustentação da rede.

\subsubsection{Usos do ambiente e "personalidade eletrônica"}

Como a interação seria a base da organização, estrutura e dinâmica de sistemas como as redes sociais online, elas não podem existir se não houver interação. No entanto, podemos encontrar no ciberespaço agrupamentos que se nomeiam redes e, mais comumente, comunidades virtuais de aprendizagem - apresentando um planejamento prévio, um professor e objetivo explícito de desenvolver uma ou mais aprendizagens - sem que haja comunicação entre os participantes ou muito pouca.

Nesses casos, as pessoas entram em um ambiente virtual onde se desenvolvem projetos de aprendizagem apenas para consultar materiais disponibilizados e/ou para se relacionar exclusivamente com o professor, sem interagir com os demais. Outras vezes, o ambiente virtual de aprendizagem é utilizado como "site", divulgando conteúdos, mas sem uma proposta educativa, situações didáticas e interação entre os inscritos no ambiente. Não poderíamos classificar esses casos como redes de aprendizagem online porque as pessoas não agem entre si, não se relacionam. 
Essas são algumas das observações realizadas no Portal EducaRede ${ }^{31}$ durante a escolha de uma rede de aprendizagem que pudesse ser analisada nesta investigação. Até nos decidirmos pela rede "POIEs do Butantã", visitamos as 52 redes de aprendizagem que constavam no Portal e pudemos observar diversos usos do ambiente criado para o desenvolvimento de projetos educativos em rede.

Alguns gestores (nome que recebia o responsável pela rede) utilizam as ferramentas do ambiente apenas para disponibilizar conteúdos para consulta. Não havia atividades propostas e os espaços de interação encontram-se vazios. Nesses casos, a não-interação parece resultar da ausência de situações didáticas, mais do que da dificuldade encontrada pelo gestor em estimular a interação.

As pessoas apropriam-se dos mais diversos ambientes e ferramentas de modos diferentes para o quais eles foram construídos, visando atender a seus projetos, necessidades e interesses - um comportamento que seria muito encontrado no ciberespaço.

A CVA SEED - Seminários e Estudos em Epistemologia e Didática - FE/USP ${ }^{32}$ é um destes casos, em que o ambiente desenhado para a aprendizagem em rede é usado como site, ou seja, apenas para a divulgação e armazenamento de conteúdos. Os gestores disponibilizam textos do livro impresso "Linguagem e Educação", além de todos os apresentados nos Seminários e os calendários dos encontros presenciais. Mas não há interação em qualquer ferramenta, provavelmente por causa dos encontros que acontecem todas as sextas, na USP, desde 1997, somado ao fato de não haver atividades propostas no espaço virtual. O objetivo dos gestores da CVA SEED seria preservar e divulgar a memória do grupo de estudos por meio do ambiente do EducaRede. A interação acontece nos encontros às sextas-feiras e, assim, teríamos uma rede de aprendizagem presencial, mas não online.

Outro exemplo é a CVA Avisa Lá - Comunidade de Formadores ${ }^{33}$. Em 2008, os gestores publicaram conteúdos e pediram para que outras pessoas do grupo também o façam porque usam o espaço como local de compartilhamento de textos de interesse. Os participantes são formadores que se reúnem presencialmente com freqüência, mas não interagem no ambiente virtual. Como as produções publicadas não recebem comentários e não

\footnotetext{
${ }^{31}$ As comunidades virtuais de aprendizagem do Portal EducaRede estão disponíveis no endereço: www.educarede.org.br/comunidades, acessado em 22 jun. 2008. Algumas são abertas para visitação. Pudemos entrar em todas porque, na época, esta pesquisadora era responsável por ajudar os gestores dessas redes.

${ }^{32}$ Disponível em < http://www.educarede.org.br/educa/index.cfm?id comunidade=132>. Acesso em 23 jun. 2008.

${ }^{33}$ Disponível em < http://www.educarede.org.br/educa/index.cfm?id_comunidade=149 $>$. Acesso em 23 jun. 2008.
} 
há mensagens de qualquer outro tipo entre as pessoas naquele espaço, não consideramos esse caso uma rede de aprendizagem online.

Sem o processo comunicativo e relacional, não podemos falar em rede de aprendizagem, muito menos em comunidade, onde os laços entre os participantes são mais estreitos. Interagir é comunicar-se e toda e qualquer comunicação é feita por meio da linguagem. Essa, por sua vez, não pertence à pessoa, embora a constitua dando forma à sua consciência (BAKHTIN, 1981). A linguagem, como comunicação, é fluxo, processo, que pode ser potencializado pelo ciberespaço.

Apesar dessa potencialidade, a interação em ambiente virtual não seria algo natural para a maioria das pessoas. Diferente do relacionamento face a face, a interação mediada pela máquina exigiria uma "competência semiótica do usuário para lidar com interfaces computacionais", como explica Santaella:

Essa competência semiótica implica a vigilância, receptividade, escolha, colaboração, controle, desvios, reenquadramentos em estados de imprevisibilidade, de acasos, desordens, adaptabilidade que são, entre outras, as condições exigidas para quem prevê um sistema interativo e para quem o experimenta (SANTAELLA, 2007, p. 166)

Além dessas competências, fazer parte de uma rede online pode ser difícil para algumas pessoas porque, segundo JONES (1995), elas teriam que desenvolver uma "personalidade eletrônica". Pesquisas realizadas por Paloff e Pratt (2002) demonstraram que, para a personalidade existir, certos elementos precisam se manifestar:

- a capacidade de dar continuidade a um diálogo interno a fim de formular respostas;

- a criação de uma imagem de privacidade, tanto em termos do espaço a partir do qual a pessoa comunica-se quanto da capacidade de criar um sentimento interno de privacidade;

- $\quad$ a capacidade de lidar com questões emocionais pela forma textual;

- a capacidade de criar uma imagem mental do parceiro durante o processo comunicativo;

- a capacidade de criar uma sensação de presença on-line por meio da personalização do que é comunicado. (PRATT e PALOFF, 2002, p.46).

Nas redes e comunidades de aprendizagem criadas por educadores no Portal EducaRede, observamos que, de modo geral, os agrupamentos com interação reúnem participantes que já possuem algum conhecimento no uso das novas tecnologias, passaram por programas de formação e/ou também se reúnem presencialmente. Ou seja, teriam tido alguma experiência anterior para desenvolver sua "personalidade eletrônica". Os encontros presenciais também seriam muito importantes para criar laços entre as pessoas, 
principalmente entre aquelas que participam pela primeira vez de um processo de ensino/aprendizagem online.

\subsection{Redes de aprendizagem online: "POIEs do Butantã" e "Comunidade de Gestores"}

Para aprofundarmos um pouco mais o entendimento que tecemos neste trabalho a respeito das características das redes de aprendizagem online, analisamos um agrupamento constituído no Portal EducaRede chamado "POIEs do Butantã". O exame nos permite refletir a respeito dos elementos que distinguem uma rede de aprendizagem de outras redes sociais no ciberespaço. Também apontamos se o agrupamento "POIEs do Butantã" seria uma rede ou uma comunidade de aprendizagem, levando-se em conta nossa reflexão a respeito dessa diferenciação realizada no capítulo anterior.

Em seguida, apresentamos uma proposta inicial de concepção de uma rede de aprendizagem online, também no Portal EducaRede, a "Comunidade de Gestores". Além de exemplo, seria uma forma de explicitar ainda mais a posição teórico-epistemológica que norteia nossa visão de trabalho nesse tipo de agrupamento.

\subsubsection{A Rede de Aprendizagem online "POIEs do Butantã"}

A rede de aprendizagem online "POIES o Butantã"34 foi criada no Portal EducaRede em fevereiro de 2008 pela docente Elayne Fernandes Moura Leite, responsável pela formação dos Professores Orientadores de Informática Educativa (POIEs) da Diretoria Regional de Educação do Butantã, órgão da Secretaria Municipal de Educação de São Paulo. O POIE fica no laboratório de informática das escolas onde desenvolve projetos com os alunos.

Ao dar início à rede de aprendizagem online, Elayne tinha como objetivo formar 42 educadores da região para atuarem como POIEs. Em rede, eles aprenderiam a exercer a função, a desenvolver projetos e elaborar planos de aula, a melhor tirar proveito do laboratório de informática, a refletir sobre Educação e tecnologia a partir de textos teóricos, além de outros assuntos que os participantes achassem importante trazer para o grupo. A rede

\footnotetext{
${ }^{34}$ Disponível em <http://www.educarede.org.br/educa/index.cfm?id_comunidade=147> $>$. Acesso em 12 de ago de 2008.
} 
foi criada para complementar os poucos encontros presenciais de formação - quatro, no ano que Elayne teria com os professores, além de manter contato com eles ao longo do processo.

Em 13 de agosto de 2008, a rede "POIEs do Butantã" reunia 32 participantes, incluindo a professora responsável. Vale ressaltar que o fato de existir uma lista de discussão no site Yahoo há mais de sete anos, "obrigava" os professores a entrar e participar em dois ambientes virtuais distintos.

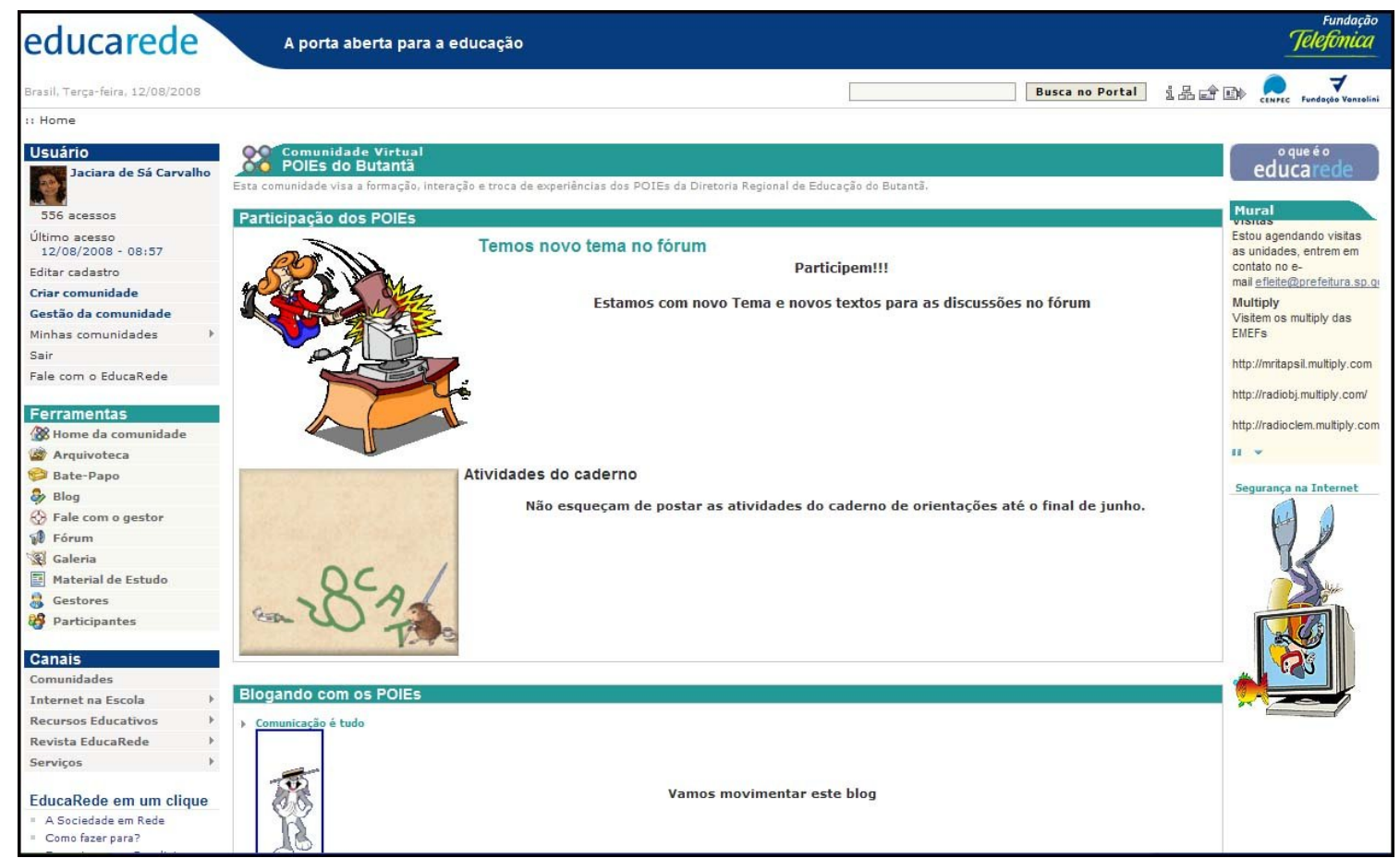

Figura 6: Homepage do ambiente virtual da rede "POIEs do Butantã"

Fonte: Reprodução

A rede "POIEs do Butantã" poderia ser considerada de aprendizagem porque encontramos as características por nós assinaladas nesse tipo de rede: uma professora, uma proposta inicial e o objetivo educativo explícito.

Como já tratado, as redes de aprendizagem apresentam um processo de ensino na medida em que esse é entendido como um esforço intencional e orientado em formar e informar os participantes da rede. A organização e as propostas publicadas no ambiente virtual deixam explícito o esforço, revelando, também, situações didáticas.

Nos encontros presenciais, a orientadora Elayne percebeu que as discussões ficavam na superficialidade porque faltava aos POIEs mais embasamento teórico para sua prática. Ao 
criar a rede, o planejamento inicial previu a indicação de textos e de questões para discussão no ambiente virtual.

O espaço privilegiado para essa atividade foi a ferramenta "Fórum", que apresentava temas como "Os computadores na escola" e "Contribuições para a informática educativa" para debate acompanhados de indicação de leitura. As observações que apresentamos aqui, a respeito da rede "POIEs do Butantã", foram realizadas na segunda semana de agosto de 2008.

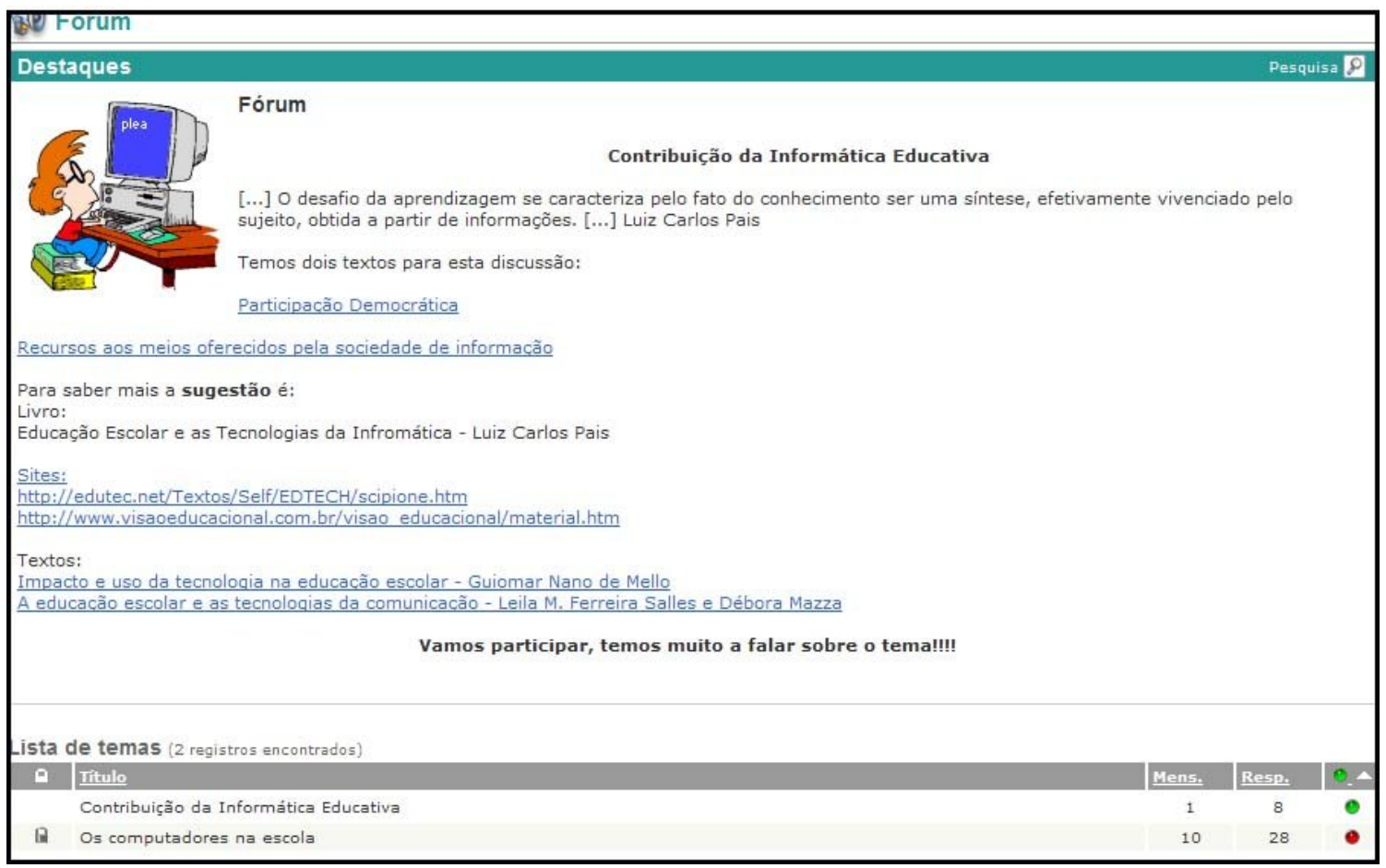

Figura 7: Página principal da ferramenta "Fórum" Fonte: Reprodução

Além de fomentar discussões, a professora propôs a publicação no ambiente de uma ou mais atividades desenvolvidas pelos POIEs com os alunos no $1^{\circ}$. semestre daquele ano, para que compartilhassem seus projetos com os demais da rede. A "tarefa" devia ser disponibilizada na ferramenta "Arquivoteca", onde os participantes também publicaram outros conteúdos de interesse do grupo. 


\begin{tabular}{|c|c|c|c|}
\hline \multicolumn{4}{|c|}{ Lista de arquivos (33 registros encontrados) } \\
\hline Tipo & Iftulo & Pasta & Data $\vee$ \\
\hline 밀 & Reflexo de mim & IGeral & $04 / 08 / 2008$ \\
\hline 国 & Jornal - Notícia do Mange & IGeral & $04 / 08 / 2008$ \\
\hline 田 & Identidade - Quem sou eu? & IGeral & $04 / 08 / 2008$ \\
\hline$\theta$ & PARLENDAS & IGeral & $29 / 07 / 2008$ \\
\hline 国 & POESIA TIETÊ & \Geral & $29 / 07 / 2008$ \\
\hline 国 & DIA DO ÍNDIO & IGeral & $29 / 07 / 2008$ \\
\hline 霆 & POESIA PARA O DIA DAS MÃES & IGeral & $29 / 07 / 2008$ \\
\hline 濑 & IDENTIDADE & |Geral & $29 / 07 / 2008$ \\
\hline ت & PARLENDAS & |Geral & $29 / 07 / 2008$ \\
\hline 圆 & $\begin{array}{l}\text { Festival de curtas sobre o Solano } \\
\text { Trindade }\end{array}$ & IGeral & $23 / 07 / 2008$ \\
\hline 国 & Artistas digitais & IGeral & $01 / 07 / 2008$ \\
\hline$?$ & EMEF CEU Butantã Projeto Cordel & IGeral & $30 / 06 / 2008$ \\
\hline
\end{tabular}

Figura 8: Página da ferramenta "Arquivoteca" Fonte: Reprodução

Na ferramenta "Material de Estudo", a professora publicou textos sobre Emília Ferreiro, participação democrática, sociedade da informação e o "Caderno de Orientações Didáticas Ler e Escrever - Tecnologias na Educação" que havia selecionado para informação/formação dos participantes.

Como formam uma rede, os integrantes também propuseram outros materiais. Por meio das interações no "Blog", soubemos que o modelo de planilha para as atividades dos POIEs no $2^{\circ}$. sem. e a íntegra de uma portaria que orienta o trabalho dos professores foram publicados a partir de sugestão e da importância destacada pelos participantes.

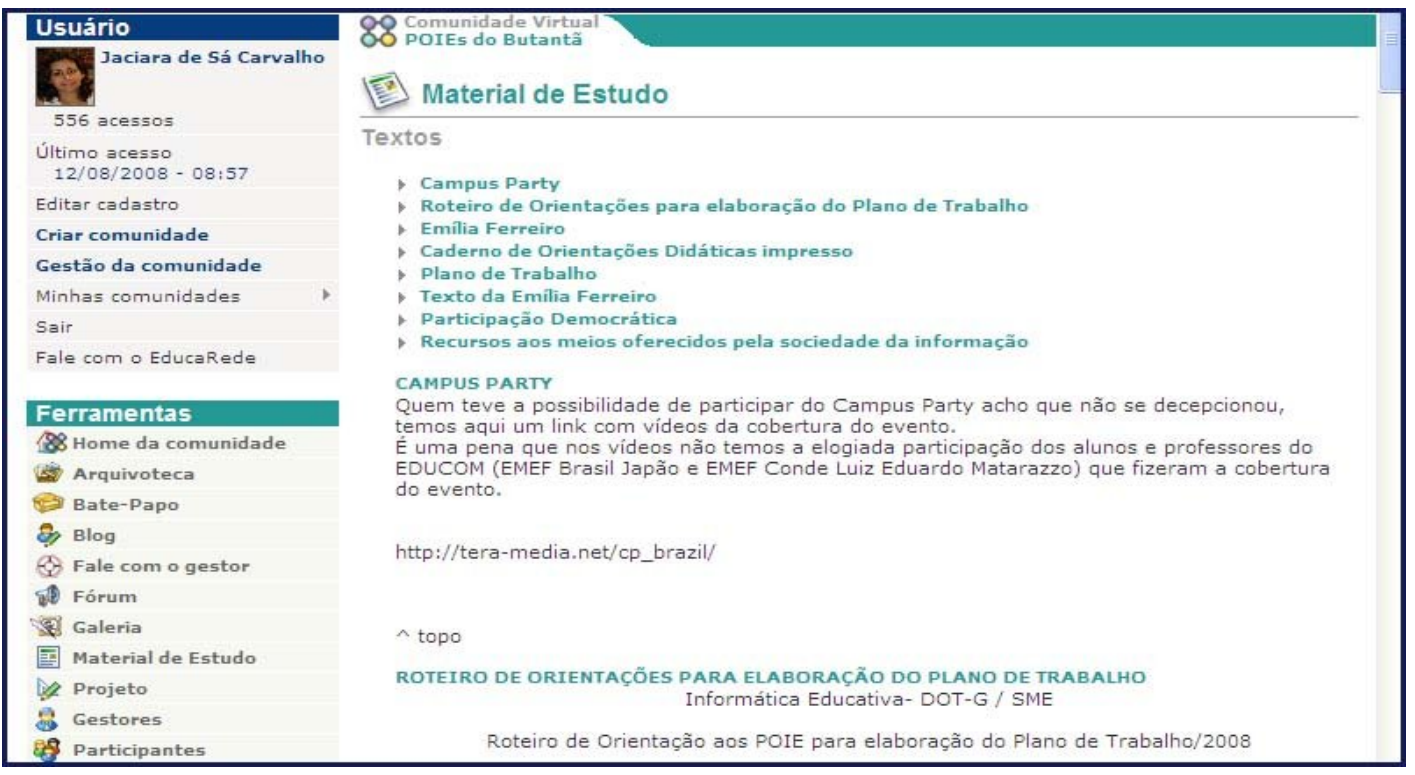

Figura 9: Página da ferramenta "Material de Estudo" Fonte: Reprodução 
Essa "abertura" existe porque, embora haja a figura do professor, tratamos aqui de uma estrutura de rede. Todos podem propor atividades e o que mais acharem pertinente ao processo educativo porque as relações são horizontais e todos são responsáveis pela aprendizagem de todos.

Segundo Elayne, ela deixou claro para os POIEs que, embora desse início ao agrupamento e seu papel fosse estimular a aprendizagem, orientando quando necessário, a rede era responsabilidade de todos, até porque seus conhecimentos eram semelhantes à de alguns daqueles professores que se tornaram POIEs no final da década de 90 junto com ela.

A ferramenta "Bate-papo" é usada pela rede para conversas síncronas. No primeiro semestre de 2008, três deles foram realizados:

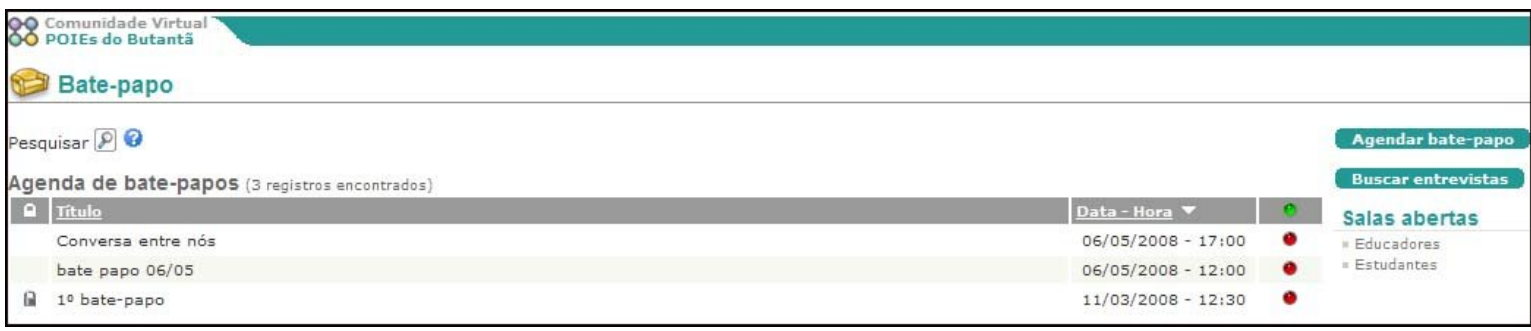

Figura 10: Página da ferramenta "Bate-papo"

Fonte: Reprodução

As ferramentas que fazem parte do ambiente virtual seriam um dos componentes da chamada "cognição distribuída" ou, ainda, "inteligência distribuída". Ao tratar de comunidades virtuais de aprendizagem, Passarelli (2007) ressalta que nos últimos anos a perspectiva de que a cognição "acontece na cabeça" do indivíduo tem sido desafiada por autores que destacam uma relação intrínseca entre o pensamento, a ação e meio ambiente. Passarelli cita vários pesquisadores, como Marlene Scardamalia \& Carl Bereiter e Howard Gardner, que atrelam a mente à organização cultural.

A partir do princípio que a cognição é distribuída, ferramentas, regras, valores e atores em sala de aula constituem um sistema interativo de grande complexidade. Livros-texto, notebooks, canetas, a organização das carteiras a escrita no quadronegro e boletins de aviso são vistos como artefatos culturais carregados de inteligência. Outras formas de distribuição podem ser observadas em atividades colaborativas, nos moldes do trabalho de pesquisa acadêmica e nas conversas de criança quando jogam. (PASSARELLI, 2007, p. 48). 
As ferramentas "Material de Estudo", "Fórum", "Blog”, "Bate-papo" e "Arquivoteca" fariam parte desse "sistema interativo de grande complexidade" e seriam meios para proporcionar a elaboração e a distribuição de informações entre os participantes.

Entre essas ferramentas, destaca-se o "Blog" do ambiente em questão por ser um espaço no qual todos podem postar e/ou comentar mensagens de forma livre, sem definição de uma temática. O sentimento de estar em rede e o compromisso com o outro se manifestariam mais espontaneamente nesse mural de recados e de discussão.

\section{Análise qualitativa e quantitativa}

Para considerarmos o agrupamento "POIEs do Butantã" uma rede ou uma comunidade de aprendizagem, além dos elementos distintivos das redes de aprendizagem online, analisamos a quantidade e o conteúdo de mensagens trocadas por meio da ferramenta "Blog" no mês de junho de 2008. Nosso objetivo foi conhecer o grau de interação entre os participantes.

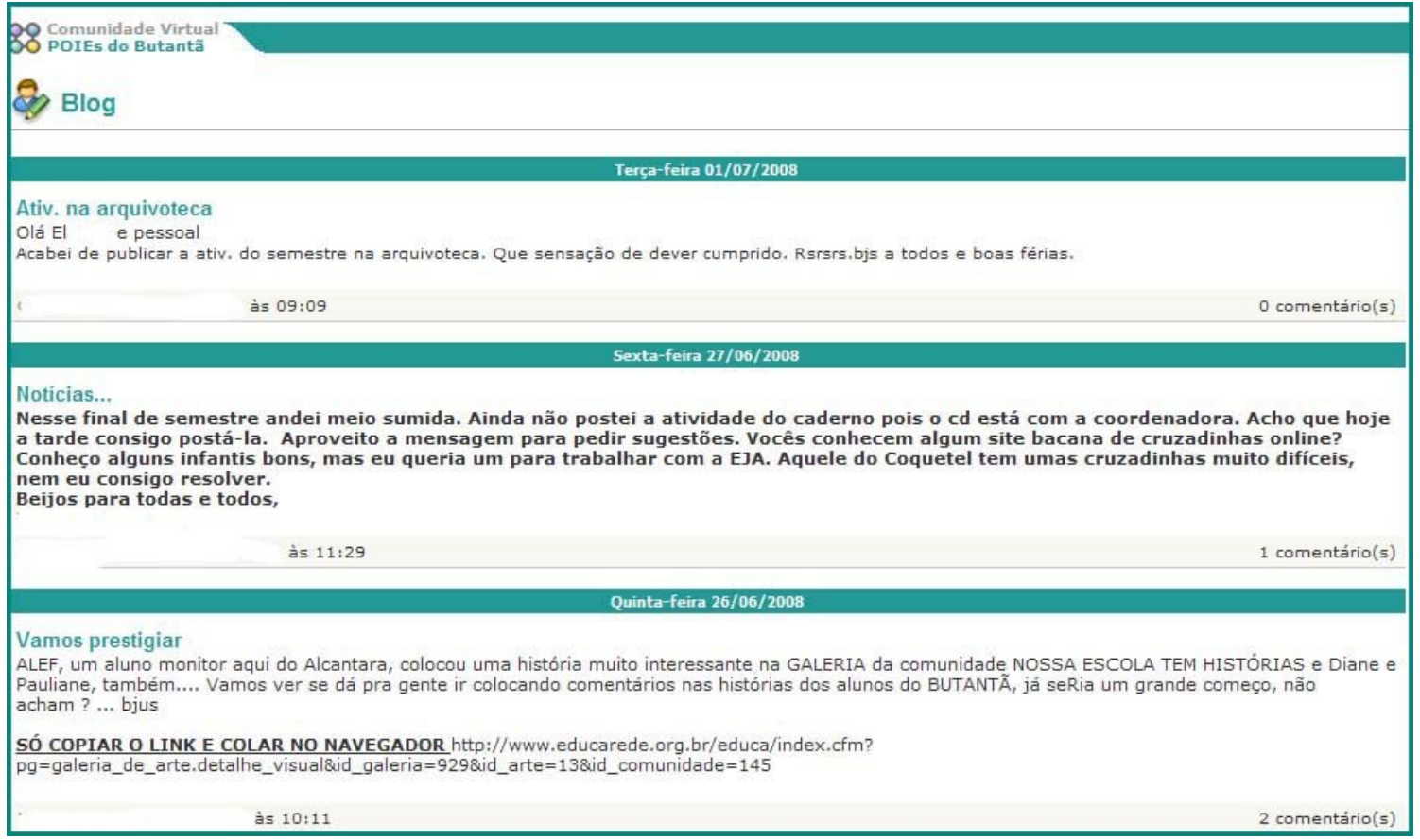

Figura 11: Página da ferramenta "Blog" Fonte: Reprodução 
A análise qualitativa das mensagens trocadas no período (APÊNDICE A) visa identificar se havia colaboração entre os participantes por meio do "Blog". Como aquele era um espaço livre para conversação, sem atividades a cumprir, consideramos que a colaboração se manifestava por qualquer conteúdo que contribuísse com a aprendizagem dos colegas.

A partir da leitura das mensagens e comentários, categorizamos o conteúdo de acordo com o que acreditamos ser o objetivo principal dos autores ao publicá-las, ou seja, qual intencionalidade estaria expressa pelo conteúdo.

Poderia ser apenas uma "Informação" à rede, algo que o autor desejaria comunicar a todos ou a alguém especificamente. Exemplo: “Achei ótima a sua planilha para o $2^{\circ}$ semestre. Vou adotá-la. Obrigada".

Embora todas as mensagens sejam uma informação, o conteúdo de algumas delas expressaria um pedido de auxílio aos colegas. Essas mensagens foram categorizadas como "Pedido de Colaboração". Exemplo: "Aproveito a mensagem para pedir sugestões. Vocês conhecem algum site bacana de cruzadinhas online?

Respondendo a um pedido, ou sendo espontâneas, algumas mensagens manifestariam uma postura colaborativa do autor diante do grupo. Sabemos que, de certa forma, todas as mensagens contribuem com a rede, mas algumas revelariam mais claramente o objetivo dessa contribuição, tendo sido enviadas com o desejo explícito de colaborar.

A mensagem "Fiz outro modelo já pensando no segundo semestre e postei na "Arquivoteca"” seria um exemplo de conteúdo colaborativo porque nessa rede não existe a obrigatoriedade para que se compartilhe o que é feito na escola, apenas uma solicitação/sugestão do responsável para a divulgação. Também poderia ser considerada colaborativa na medida em que as atividades podem ser adotadas pelos colegas.

Mensagens com dicas de matérias jornalísticas e sites também são assinaladas como colaborativas porque seu objetivo explícito seria o enriquecimento do grupo - a pessoa deu-se ao trabalho de apresentar sugestões apenas para colaborar com o conhecimento dos demais, sem que isso fosse uma solicitação. Também contamos como colaborativas as mensagens cujo objetivo é divulgar conteúdos produzidos pela escola, já que podem servir de modelo e inspiração para os participantes.

Por meio desses critérios, a análise das mensagens e comentários do mês de junho revelaria que a maioria das postagens teria um caráter colaborativo. Foram contabilizados 39 "pedidos" e "colaborações" contra 24 "informações" (APÊNDICE A). 
A colaboração não seria apenas um elemento importante para que os laços entre os participantes se mantenham e solidifiquem. Mas para o próprio processo de aprendizagem em rede, que depende do outro para acontecer.

No mês analisado, foram enviadas 27 mensagens e 36 comentários à ferramenta "Blog”, somando 63 publicações. A partir desse total, mapeamos a média de postagens para termos um panorama do grau de interação daquela rede, em junho de 2008.

\begin{tabular}{|c|c|}
\hline Pessoas inscritas como participantes da rede & 32 \\
\hline Participantes que postaram (incluindo o professor) & 11 \\
\hline Dos 11, quantos participantes mais enviaram? & 4 \\
\hline Média de mensagens enviada pelos 4 participantes & entre 7 e 13 \\
\hline Participantes que NÃO postaram no Blog & 20 \\
\hline
\end{tabular}

Quadro 1: Mapeamento da interação em junho no Blog da rede "POIEs do Butantã"

Fonte: Dados da pesquisa

Pelos dados mapeados, percebe-se que apenas quatro dos 32 participantes inscritos na rede interagiram com freqüência (em relação aos demais) no mês de junho. A maioria dos inscritos, ou seja, vinte deles, não fizeram qualquer postagem no "Blog", ferramenta mais utilizada para interação.

Emitimos do ambiente um relatório com a quantidade de mensagens e comentários enviados entre $\mathbf{1}^{\mathbf{0}}$. de março (mês em que as atividades começaram) e $\mathbf{1}^{\mathbf{o}}$. de agosto de 2008 (mês em que este estudo foi realizado). O levantamento no período informa:

\begin{tabular}{|c|c|}
\hline Mensagens postadas no "Blog" & 124 \\
\hline Comentários às mensagens & 167 \\
\hline Total & 291 \\
\hline Participantes que postaram (incluindo o professor) & 18 \\
\hline Dos 18, quantos participantes mais enviaram, excluindo a professora? & 6 \\
\hline Média de mensagens enviada pelos 5 participantes & entre 20 e 30 \\
\hline Pessoas que NUNCA postaram no "Blog" em 5 meses & 14 \\
\hline Média de mensagens e comentários enviados pelos participantes no período & 16 \\
\hline
\end{tabular}

Quadro 2: Mapeamento quantitativo da interação no "Blog” entre março e agosto Fonte: Dados da pesquisa 
Quando dividimos a média de mensagens enviadas por cada participante (16) pela quantidade de meses (5), vemos que apenas três mensagens teriam sido enviadas por participante a cada mês. Seria uma quantidade pequena de interação para um processo de aprendizagem em rede, mesmo se considerarmos a quantidade de mensagens enviadas pelos cinco participantes mais ativos: entre 20 e 30 em cinco meses, ou seja, entre quatro e seis por mês (em média).

\section{Constatação}

O agrupamento "POIEs do Butantã" revela características de um processo de ensino: uma professora, um planejamento inicial e o objetivo educativo explícito. Esses elementos distinguem essa rede das demais do ciberespaço como sendo de aprendizagem e contribuem para os objetivos desta pesquisa. O agrupamento também apresenta interação entre os participantes, elemento estrutural de uma rede social.

Examinamos as trocas ocorridas por meio da ferramenta "Blog" para identificar se as pessoas formavam uma comunidade virtual de aprendizagem. Os dados quantitativos revelam que apenas seis pessoas, incluindo a professora, se relacionam com freqüência e, ainda assim, seriam poucas as trocas para todo um mês (quatro a seis). A análise qualitativa do conteúdo da interação, por amostragem, no mês de junho, revela que a maioria das mensagens e comentários seria colaborativa.

Assim, encontramos colaboração, mas sem freqüência nesse agrupamento e, portanto, o classificaríamos como uma rede de aprendizagem online. Em momento algum se pretende dar a entender que o ideal seria essa rede transformar-se em uma comunidade virtual. As redes possuem uma dinâmica própria e também proporcionam aprendizagens e levam os participantes a construírem suas "redes de significações" (MACHADO, 2004). Cada rede tem movimento e tempo próprios, adequados aos interesses e disponibilidades de seus participantes. Portanto, não há aqui julgamento de valor. 


\subsection{2 “Comunidade de Gestores”: uma rede em construção}

Em 2008, esta pesquisadora apresentou uma proposta de aprendizagem a internautas interessados em aprender a desenvolver projetos e gerir redes de aprendizagem online. A elaboração e o desenvolvimento da proposta era uma das minhas funções no âmbito do Portal EducaRede, realizada por meio do agrupamento chamado "Gestores de Comunidades Virtuais de Aprendizagem". Naquele ano, o Portal disponibilizou ambientes virtuais para que educadores desenvolvessem projetos a distância.

Mais conhecida como "Comunidade de Gestores", essa rede de aprendizagem online tinha como princípio o estímulo à colaboração entre seus integrantes para tentar constituir, dentro em si e nas redes que os participantes desenvolveriam, uma ou mais comunidades. Iniciada em setembro de 2007, esteve fechada entre janeiro e maio de 2008, quando foi reaberta com a concepção que será detalhada. A proposta também foi elaborada a partir da disciplina “Ensinando em Ambientes Virtuais 1", cursada durante o mestrado em Educação.

\section{Pressupostos teóricos}

A rede "Comunidade de Gestores" foi pensada a partir de uma perspectiva dialógica, problematizadora e colaborativa que levasse os participantes a compartilharem conquistas e desafios de se trabalhar no ciberespaço, ajudando uns aos outros e refletindo sobre suas ações.

Nessa perspectiva, somada a nossas experiências em ambientes virtuais de aprendizagem, diríamos que a Pedagogia Crítica é uma teoria muito adequada às atividades online porque privilegia o diálogo, a colaboração e a práxis. Esses três pontos, intrinsecamente ligados, seriam fundamentais para a constituição de uma comunidade formada por educadores que pretendem inovar e refletir sobre sua prática.

A maioria dos participantes da "Comunidade de Gestores" era de educadores que desejam aprender a ensinar a distância. Já possuíam experiência com formação presencial, mas buscavam novas práticas pedagógicas para a Educação por meio de ambientes virtuais.

Assim, além de conhecerem ferramentas e seus usos para o trabalho em rede, seria necessária uma reflexão sobre a prática, uma "reflexão e ação dos homens sobre o mundo para transformá-lo" (FREIRE, 2005, p. 42). Somente por meio da práxis, os participantes teriam condições de desenvolver novas formas de ensinar, lembrando que o ensino não é 
apenas um ato pedagógico, mas também político, de educadores comprometidos com seus alunos e com seu tempo.

A relação entre os formadores e os participantes parte do pressuposto de que estão juntos como sujeitos do processo educativo e, assim, crescem juntos. "Dessa maneira, o educador não é o que apenas educa, mas o que, quando educa, é educado, em diálogo com o educando que, ao ser educado, também educa" (FREIRE, 2005, p. 79).

A relação de comunhão seria ainda mais pertinente quando se trata de educar utilizando novos meios de comunicação e informação, pois novas metodologias, e releituras das antigas, são desenvolvidas e pesquisadas. Freire (1996) nos lembra que aprendendo socialmente se descobre que é possível ensinar; historicamente, aprende-se a trabalhar maneiras, caminhos e métodos de ensino; portanto, "ensinar inexiste sem aprender e viceversa" (1996, p. 23).

Como gestores/formadores da "Comunidade de Gestores" tínhamos total conhecimento do ambiente virtual (do Portal EducaRede) no qual a maioria dos educadores desenvolveriam suas redes, clareza quanto aos objetivos propostos, experiência quanto à metodologias em ambientes virtuais, domínio dos conteúdos e dos significados em diferentes contextos que eram discutidos na comunidade, assim como capacidade para adequá-los ao processo de realização desta proposta.

Ou seja, no papel de "educadores-problematizadores" pretende-se proporcionar “condições em que se dê a superação do conhecimento no nível da doxa pelo verdadeiro conhecimento, o que se dá no nível do logos" (FREIRE, 2005, p. 80). Mas sempre "com os participantes", em uma relação na qual ambos se educam, de forma dialética e dialógica, mediatizados pelo mundo.

Para efetivar a proposta de uma educação em comunidade, seria necessário mostrar aos participantes que não éramos "donos do saber", mas "problematizadores" da realidade em questão e que com eles iríamos refletir e agir. Trata-se de uma Educação para a liberdade, que pressupõe um diálogo crítico entre pessoas livres.

É por meio do diálogo que se pretende dar condições para que os participantes da Comunidade tornem-se gestores/educadores livres para inovar e criticar usos de ambientes virtuais com seus alunos. Liberdade, diálogo, comunhão são nós de uma mesma rede e premissas importantes para o trabalho em comunidade virtual de aprendizagem.

Na primeira homepage da comunidade, essa proposta foi apresentada: 


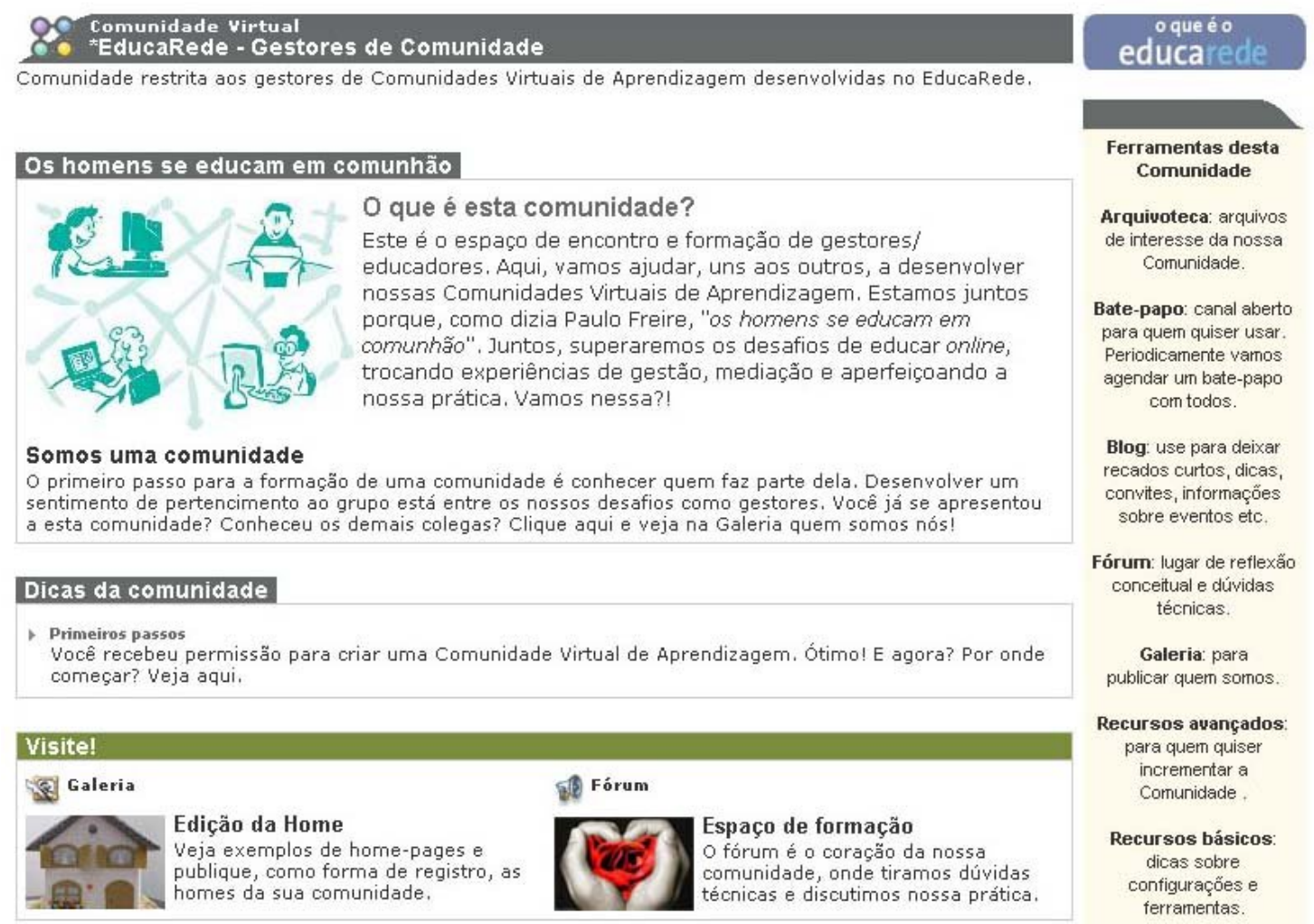

Figura 12 - Homepage do ambiente da rede "Comunidade de Gestores" Fonte: Reprodução

A comunhão provoca a co-laboração e essa não pode ser realizada a não ser entre sujeitos e, portanto, por meio da comunicação. "O diálogo, que é sempre comunicação, funda a co-laboração" (FREIRE, 2005, p. 193) porque o diálogo não impõe, não maneja, não domestica; seu compromisso é com a autonomia.

[...] na co-laboraçao, exigida pela teoria dialógica da ação, os sujeitos dialógicos se voltam sobre a realidade mediatizadora que, problematizada, os desafia. A resposta aos desafios da realidade problematizadora é já a ação dos sujeitos dialógicos sobre ela para transformá-la. (2005, p. 193).

\section{Diálogo}

O diálogo coloca em destaque a palavra. E o que são os ambientes virtuais destinados ao ensino/aprendizagem sem ela? Os processos educativos que apenas disponibilizam textos para leitura dos alunos tornam o ambiente um rico mural, mas sem vida. Os espaços virtuais vivos, nos quais a aprendizagem é visível, seriam aqueles que destacam a palavra dos participantes, colocam o diálogo como personagem principal. 
Uma Educação dialógica pode ter o ciberespaço como um grande aliado, uma vez que os participantes podem expressar suas idéias sem os olhares ansiosos da platéia da sala de aula presencial, ficando, assim, mais à vontade para se expor.

Se a dinâmica adotada no ambiente propiciar situações que permitam aos participantes refletirem a cerca do tema, ter-se-ia, então, não apenas a palavra de todos, mas uma palavra que pode ser fruto de reflexão e não do imediatismo que geralmente acontece nas situações não-virtuais.

Os ambientes virtuais de aprendizagem, preponderantemente, dependem da escrita, e ela de elaboração, de mobilização do conhecimento. Seria esse mais um bom motivo para o ensino nestes espaços. "Não é no silêncio que os homens se fazem, mas na palavra, no trabalho, na ação-reflexão" (FREIRE, 2005, p. 90).

Paulo Freire explica que, ao pronunciarmos o mundo, ele se volta a nós problematizado, exigindo de nós um novo pronunciar. Em uma comunidade virtual de aprendizagem esses pronunciamentos são compartilhados e a reflexão pode ser ainda mais rica com a contribuição dos colegas. Ambientes virtuais de aprendizagem e uma proposta baseado na dialogicidade seriam, assim, nós de uma mesma rede.

A dialogicidade como proposta para trabalho em ambiente virtual começa antes do "estar em rede". Inicia-se com o educador ao se perguntar em torno do que vai dialogar com os participantes. "Para o educador-educando, dialógico, problematizador, o conteúdo programático não é uma doação ou uma imposição - um conjunto de informes a ser depositado nos educandos -, mas a devolução organizada daqueles elementos que este lhe entregou de forma desestruturada" (FREIRE, 2005, p. 96).

Por isso, o quadro a seguir apresenta uma proposta inicial de conteúdo programático com temas que seriam de interesse dos participantes da "Comunidade de Gestores". Ao longo do desenvolvimento da comunidade, "organizamos" as necessidades e os interesses dos participantes que chegaram a nós de maneira "desorganizada".

\section{A proposta}

Após contextualização e pressupostos, detalhamos a proposta no quadro abaixo de criação da rede de aprendizagem online "Comunidade de Gestores": 


\begin{tabular}{|c|c|}
\hline \multicolumn{2}{|r|}{ Detalhamento da Proposta } \\
\hline 1. Nome da rede de aprendizagem & $\begin{array}{l}\text { Gestores de Comunidades Virtuais de Aprendizagem ("Comunidade de } \\
\text { Gestores") }\end{array}$ \\
\hline 2. Justificativa & $\begin{array}{l}\text { A rede "Comunidade de Gestores" pretende atender às demandas de } \\
\text { apoio tecnológico e de formação dos educadores que deram início a } \\
\text { comunidades virtuais de aprendizagem localizadas no Portal } \\
\text { EducaRede e de demais interessados em aprender a desenvolver } \\
\text { projetos em rede. }\end{array}$ \\
\hline 3. Objetivos & $\begin{array}{l}\text { Apoiar e contribuir para a formação de educadores interessados em } \\
\text { gerir comunidades virtuais de aprendizagem. Formar uma comunidade } \\
\text { de educadores baseada na colaboração, que possa ser auto-sustentável } \\
\text { com o passar do tempo. }\end{array}$ \\
\hline 4. Formadores & Dois integrantes da equipe EducaRede (um responsável e um apoio) \\
\hline 5. Público & $\begin{array}{l}\text { Educadores em geral, interessados em aprender, em comunidade, a gerir } \\
\text { comunidades virtuais de aprendizagem. A maioria dos educadores } \\
\text { deram início (ou darão) a comunidades virtuais localizadas no Portal } \\
\text { EducaRede, embora seja aberta a qualquer pessoa interessada no } \\
\text { assunto. O ingresso de novos participantes é "permanente", até quando } \\
\text { esta proposta for realizada, portanto, não há um número fechado de } \\
\text { participantes. }\end{array}$ \\
\hline 6. Duração e carga horária & $\begin{array}{l}\text { A carga horária de dedicação à CVA dependerá do interesse do } \\
\text { participante. Mas a partir das atividades propostas, calculamos } 4 \text { horas } \\
\text { quinzenais, em média. Não há previsão de conclusão desta proposta, } \\
\text { uma vez que ela pretende criar uma rede de aprendizagem auto- } \\
\text { sustentável. }\end{array}$ \\
\hline 7. Infra-estrutura & $\begin{array}{l}\text { Participantes precisam ter acesso a um computador conectado à } \\
\text { Internet. }\end{array}$ \\
\hline 8. Conteúdo programático & $\begin{array}{l}\text { A formação se daria, principalmente, por meio da discussão de temas } \\
\text { pertinentes à EaD, a partir de leituras indicadas pelos formadores. Os } \\
\text { temas iniciais são: } \\
\text { - Definição e características de CVA } \\
\text { - Participação e colaboração } \\
\text { - Gestão } \\
\text { - Mediação } \\
\text { - Avaliação }\end{array}$ \\
\hline 9. Dinâmica de formação & $\begin{array}{l}\text { No início de cada semana, um novo tema é apresentado para discussão } \\
\text { no Fórum Temático, com indicação de leituras. Na semana seguinte, o } \\
\text { mesmo tema é tratado em bate-papo com especialista no assunto e a } \\
\text { discussão volta ao fórum. Esta dinâmica se repete a cada duas ou três } \\
\text { semanas, dependendo das discussões em andamento. Vale ressaltar que, } \\
\text { embora privilegiemos o "Fórum" como espaço de formação, } \\
\text { acreditamos que ela aconteça a partir do uso das demais ferramentas, de } \\
\text { forma mais espontânea e menos programática, como, por exemplo, do } \\
\text { diálogo no "Blog". }\end{array}$ \\
\hline $\begin{array}{l}\text { Ferramentas do ambiente } \\
\text { utilizadas e suas finalidades }\end{array}$ & $\begin{array}{l}\text {-"Bate-papo": para discussão com especialistas e entre os participantes; } \\
-2 \text { "Fóruns": Tira-dúvidas (caráter técnico) e Temático (conceitual) } \\
-2 \text { "Galerias": "Quem Somos" (apresentação pessoal) e "Homes" } \\
\text { (registro das homepages criadas pelos participantes em suas } \\
\text { comunidades) }\end{array}$ \\
\hline
\end{tabular}




\begin{tabular}{|c|c|}
\hline & $\begin{array}{l}\text { - "Material de Apoio": banco de textos teóricos para subsidiar o Fórum } \\
\text { - Recursos e Ferramentas: lista de endereços de ferramentas e recursos } \\
\text { gratuitos disponíveis na web (Bubble Share, etc.) } \\
\text { - "Blog": trata-se, na verdade, de um mural para troca entre os } \\
\text { participantes de assuntos de seus interesses, embora seja incentivado o } \\
\text { relato do que acontece nas comunidades destes educadores, suas } \\
\text { conquistas, descobertas, etc. } \\
\text { - Mural da homepage da CVA: divulgação de cursos e de outros } \\
\text { recados aos participantes. }\end{array}$ \\
\hline $\begin{array}{l}\text { 11. Teoria de aprendizagem } \\
\text { principal }\end{array}$ & Pedagogia crítica \\
\hline 12. Avaliação & $\begin{array}{l}\text { Será realizado um acompanhamento das postagens no ambiente. A } \\
\text { avaliação tem como objetivo a adequação das propostas e dos temas de } \\
\text { discussão apresentados pelos formadores aos interesses e necessidades } \\
\text { dos participantes, a partir do pressuposto teórico desta proposta. }\end{array}$ \\
\hline
\end{tabular}

Quadro 3: Detalhamento da proposta da "Comunidade de Gestores"

Fonte: Dados da pesquisa

A seguir, a figura publicada na comunidade que explica a dinâmica de formação, cujo espaço privilegiado é o "Fórum":

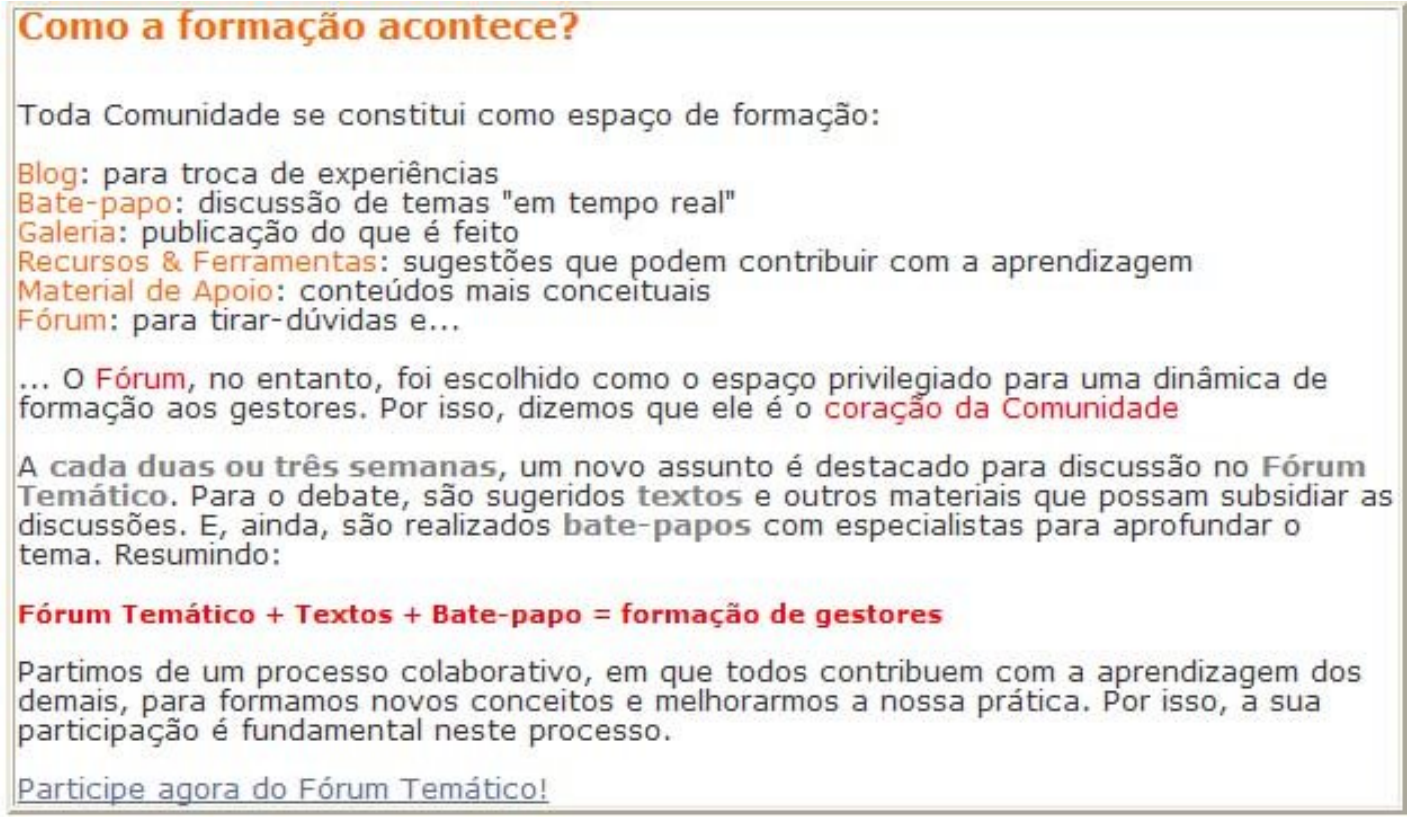

Figura 13: Explicação da dinâmica de formação na "Comunidade de Gestores" Fonte: Reprodução

Além do quadro anterior, foi publicado no ambiente virtual um mapa conceitual que apresenta a proposta desenvolvida: 


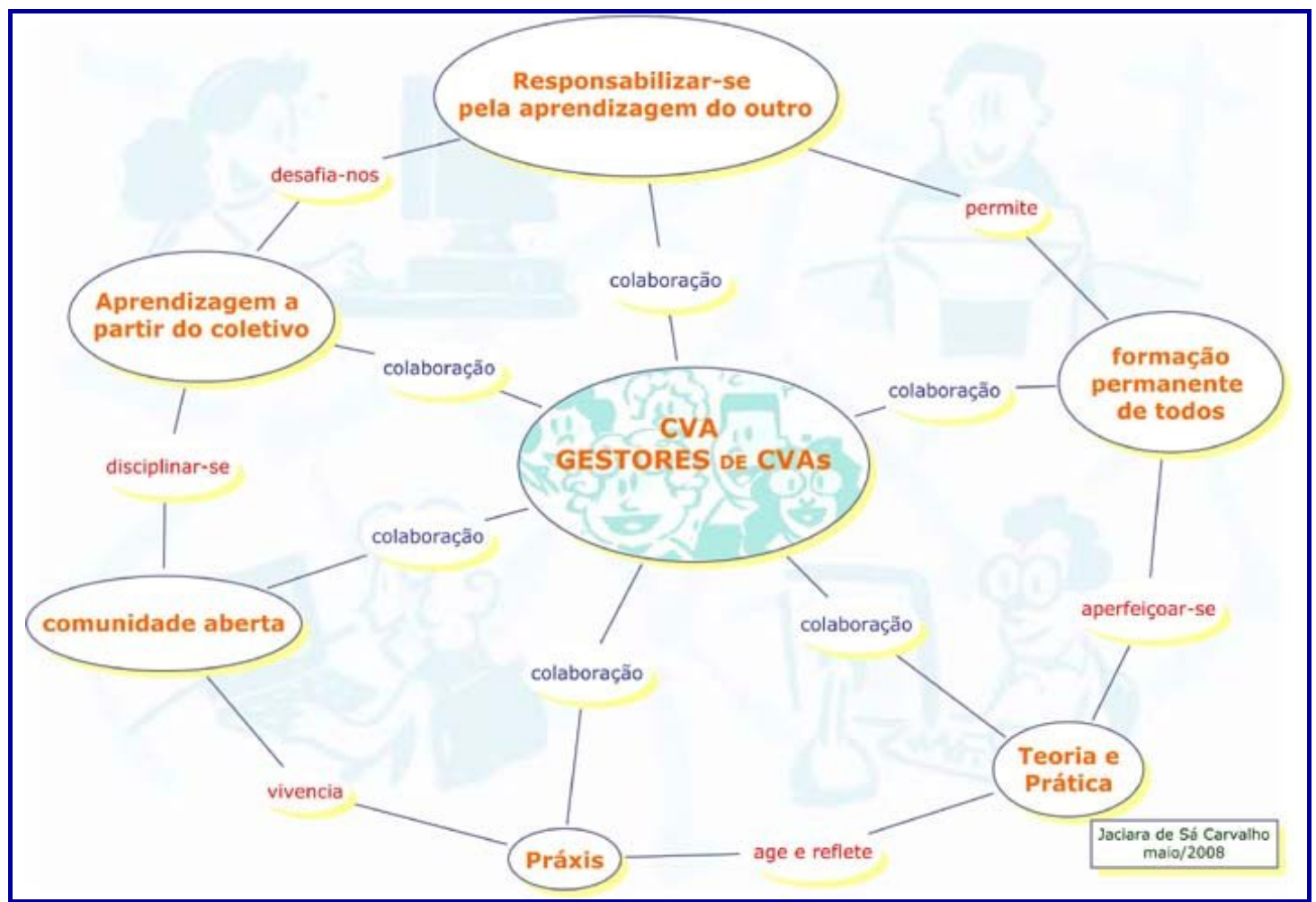

Figura 14: Mapa da proposta da "Comunidade de Gestores"

Fonte: Reprodução

\section{Desafios}

Um dos desafios que se apresenta é desenvolver entre os participantes da "Comunidade de Gestores" atitudes colaborativas que permitam a eles não só desenvolver suas redes online, mas também que a colaboração seja valorizada como parte de qualquer aprendizagem, principalmente em ambientes virtuais que permitem interação entre pessoas. Ou seja, pretende-se disseminar o espírito colaborativo para as redes das quais são professores.

Mas, uma vez que os participantes sabem que a "Comunidade de Gestores" é de responsabilidade da equipe EducaRede, existe a possibilidade de eles utilizarem o espaço apenas para tirar dúvidas e interagirem pouco uns com os outros. Esse desafio também dificultaria o nosso objetivo de problematizar com eles qual Educação se deseja via ambientes online, levando-os a refletir sobre suas práticas (práxis)

Diferentemente do que ocorre na maioria de cursos online, a "Comunidade de Gestores" é uma rede de aprendizagem online que não tem início nem fim previsto. Caracteriza-se como um grupo aberto, que recebeu novos ingressantes ao longo de sua 
existência. Essa característica tornaria mais difícil constituir um sentimento de comunidade, uma vez que haveria sempre alguém de fora do grupo chegando.

Além disso, devido a esse caráter aberto, os níveis de conhecimento entre os participantes variavam muito. Com o passar do tempo, uns conseguiram gerir suas redes sozinhos, participando da "Comunidade de Gestores" (ou não) por outros motivos, enquanto outros estavam aprendendo o básico para iniciarem atividades nas redes em que são responsáveis. Existia o desafio de conciliar interesses tão difusos e trabalhar com internautas com diferentes conhecimentos em relação à gestão.

Mas, como a proposta foi desenvolver uma comunidade, esperava-se que a colaboração fosse desenvolvida como um valor e como compromisso com a aprendizagem do colega. Em resumo, os principais desafios levantados quando essa proposta foi elaborada foram os seguintes:

- Constituir uma comunidade entre os participantes;

- Torná-la um espaço de formação, não de resolução de dúvidas técnicas do ambiente em questão;

- Disseminar o espírito colaborativo;

- Estimular os gestores que conseguiram desenvolver suas comunidades a compartilharem suas experiências (e não abandonarem a CVA Gestores de Comunidade após obterem sucesso nas suas próprias comunidades).

\subsection{Amarrando os pontos}

Neste capítulo, discorremos a respeito das características dos agrupamentos do ciberespaço voltados para a aprendizagem. Embora qualquer pessoa possa aprender em qualquer circunstância, a idéia de rede de aprendizagem sempre esteve ligada à Educação de um modo amplo.

A palavra Educação deriva do latim educatio, do verbo educare (instruir, fazer crescer, criar) próximo de ducëre (conduzir, levar até o fim) e, assim, sempre esteve "ligada à ação de conduzir a finalidades socialmente prefiguradas, o que supõe a existência e a partilha de projetos coletivos" (MACHADO, 2000, p. 20, grifo nosso). As redes de aprendizagem online se relacionam diretamente com a etimologia da palavra Educação.

PROJETO: os participantes dessas redes e comunidades compartilham uma proposta de aprendizagem e interagem para tentar cumpri-lo. Eles possuem seus projetos individuais, que os motivam para participar desse tipo de rede, mas trabalham para que o projeto em 
comum possa ser realizado. Em rede, não há nó sem ligação, não seria possível realizar apenas o projeto individual, uma vez que todos caminham na mesma direção: a de alcançar um objetivo educativo explícito, pré-determinado e que pode ser alterado ao longo do processo.

CONDUÇÃO: "o levar até o fim" a que a etimologia se refere relaciona-se à participação de alguém que possa orientar e estimular a aprendizagem, conduzindo a rede

para a realização do projeto. É o professor, que conduz sem oprimir, que dialoga, abre-se para mudanças de rotas, assopra as velas do navio quando está à deriva.

FAZER CRESCER, CRIAR: uma rede social só existe se os laços entre os participantes forem criados e crescerem o suficiente para manterem a estrutura de rede. $\mathrm{O}$ crescimento diz respeito também ao aumento de conhecimento dos membros a partir da aprendizagem em grupo.

Retomando, os elementos que distinguiriam as redes de aprendizagem no ciberespaço seriam:

- Objetivo educativo explícito

- Professor(es)

- Proposta / projeto inicial

Portanto, a Educação realmente está ligada à idéia de rede de aprendizagem tal como assumimos neste trabalho. Nada tem de espontâneo como outros agrupamentos. Caminha-se para uma finalidade educativa. 


\section{COMUNIDADES VIRTUAIS DE APRENDIZAGEM}

\subsection{Revisão da literatura}

\subsection{Colaboração e cooperação}

\subsection{A comunidade virtual de aprendizagem EAV 1}

3.3.1 Olhar da aluna-pesquisadora

Indicadores de formação de uma CVA

Reciprocidade permanente

Compromisso implícito

Iniciativa

Informalidade

Colaboração

Intervenção pontual do professor

Resumo

3.3.2 Olhares da professora e dos tutores

Histórico do curso e dos ambientes

Tutoria

Comunidade virtual de aprendizagem?

Liderança

Abordagem construcionista

\subsection{Uma costura final}




\section{COMUNIDADES VIRTUAIS DE APRENDIZAGEM}

Neste capítulo, apresentamos algumas definições de comunidade virtual de aprendizagem para mostrar a complexidade desse objeto. A revisão bibliográfica também contribui para examinarmos um curso online cujos participantes teriam constituído uma comunidade virtual de aprendizagem. Por meio do curso "Ensinando em Ambientes Virtuais 1", mapeamos elementos que apontariam tal formação.

\subsection{Revisão da literatura}

Uma rede de aprendizagem online distingue-se das demais redes do ciberespaço por apresentar uma proposta de aprendizagem inicialmente planejada - mas que permite novas proposições pelos participantes - a presença do professor e um objetivo educativo explícito. Quando, além destas características, encontramos nessas redes fortes laços e frequiente colaboração entre os participantes, com certo compromisso desenvolvido entre eles, teríamos a formação de uma ou várias comunidades virtuais de aprendizagem - o que não exclui a possibilidade de um agrupamento já surgir como comunidade.

Esse é o entendimento que vimos tecemos ao longo desta investigação e que inclui a revisão bibliográfica a ser apresentada neste ponto. Para melhor organização desta dissertação, optamos por inserir a revisão neste capítulo porque ambos se referem à expressão comunidade virtual de aprendizagem, embora a literatura também tenha contribuído para elencarmos os elementos que distinguem as redes e comunidades de aprendizagem dos demais agrupamentos do ciberespaço no capítulo anterior.

Para começarmos a revisão, recorremos à Beltrán Llera (2007) que define comunidades virtuais de aprendizagem como "organizações sociais criadas por pessoas que compartilham metas, valores e práticas sobre a experiência da aprendizagem". Sua compreensão dá-se a partir dos elementos essenciais das comunidades - sujeito, comunidade, objetivo, instrumentos, divisão de tarefas e regras - e dos seus desafios: eleger os elementos adequados para trabalhar em comunidade e para cada tarefa, conciliar os objetivos pessoais e comunitários, dividir as tarefas em função das capacidades pessoais e objetivos almejados, e 
estabelecer regras adequadas para manter um clima favorável. Embora não cite o ciberespaço literalmente, o contexto da análise se refere ao "espaço".

$\mathrm{Na}$ Educação, diz Bento Silva ${ }^{35}$ (2005), o conceito de comunidades virtuais de aprendizagem nos remete aos movimentos da Educação (Escola) Nova. Embora com idéias diferenciadas conforme as visões pedagógicas dos seus criadores (Montessori, Decroly, Freinet, etc.), esses movimentos "adotaram em comum os princípios da aprendizagem construtivista e da utilização de metodologias ativas, centradas na realização de projetos, na resolução de problemas e na aprendizagem cooperativa" (2005, p. 46). No entanto, os meios até então utilizados raramente permitiam a realização desses princípios - já os recursos atuais de comunicação virtual contribuem para a renovação pedagógica, acredita Silva. A partir da compreensão de que as comunidades virtuais de aprendizagem estariam centradas no aluno, o processo de ensino-aprendizagem se daria da seguinte forma:

- pela interação direta com os conteúdos, através do acesso a numerosas bases de dados e outras fontes de conhecimento diversificado e atualizado;

- pela participação ativa na pesquisa e exploração de informação;

- pelo estabelecimento de uma relação direta com os criadores do conhecimento, sem esquecer que cada comunidade em particular representa, ela própria, um potencial informativo pelo conhecimento que disponibiliza aos utilizadores da rede, pela importância da conversação desenvolvida em torno do jogo da comunicação e da negociação do seu sentido;

- pelo confronto e repartição da diversidade de interpretações na comunidade do saber;

- pelo apoio tutorial facultado ao aluno no desempenho de uma tarefa cognitiva complexa, papel que passa a constituir o principal desempenho do professor, a par da maior envolvência nos aspectos de natureza formativa (pessoal-afectivo-social). (SILVA, 2005, p. 47).

Sob outra perspectiva, Rodríguez Illera (2007) destaca o caráter social da aprendizagem nas comunidades virtuais, pensando a aprendizagem "sempre como resultado de uma situação comunal ou societal, mais do que como matéria meramente individual ou pessoal”. (2007, pág 117) O autor explica que essa linha provém de Vygotsky e sucessores, assim como de outras tradições tal qual o pragmatismo norte-americano de Dewey (1979) e, mais recentemente, da crítica antropológica, psicológica e pedagógica que "criticaram a visão meramente cognitiva/cognitivista da aprendizagem a partir de uma perspectiva que coloca em primeiro lugar o caráter altamente contextualizado de qualquer aprendizagem” (RODRÍGUEZ ILLERA, 2007, p. 117). Como resultado de todas elas, teríamos uma concepção que "enfatiza o caráter social e comunitário da aprendizagem e a importância dos diferentes contextos de socialização, ou de prática, como geradores dessa mesma aprendizagem” (p.117).

Nesse contexto, Rodríguez Illera recupera a distinção feita por Riel e Polin (2004) entre as comunidades virtuais de aprendizagem, orientadas para tarefas, para práticas e para a

\footnotetext{
${ }^{35}$ Professor do Instituto de Educação e Psicologia da Universidade do Minho (Portugal).
} 
construção do conhecimento. Embora, para nós, a distinção não seja tão nítida, Rodríguez Illera explica que as orientadas para tarefas, como a própria classificação indica, tem como finalidade a realização de tarefas e a elaboração de um produto - um tipo específico de trabalho/aprendizagem colaborativo em que a relevância recai sobre o contexto organizacional. Nas comunidades de prática, os integrantes se interessam por partilhar uma prática comum. A aprendizagem na partilha pode apresentar características assinaladas por Wenger (1998) - autor que Rodríguez Illera enfatiza em seu artigo - que, ao estudar as interrelações nas comunidades de prática, destaca "uma nova visão da aprendizagem, a identidade que resulta de pertencer à comunidade e o significado que se atribui às práticas comuns" (2007, p. 118).

Segundo Rodríguez Illera, também baseado em Dewey e Illeris (2002), as comunidades de prática pressupõem uma mudança nas concepções de aprendizagem, relacionando-a ao "conjunto da vida pessoal e social" e não em um "fim em si mesma" como ocorre em abordagens meramente pedagógicas ou psicológicas -, mas como um "componente a mais do conjunto da experiência"36 (2007, p. 119). Há de se considerar que tal reflexão não se baseia em comunidades “virtuais" de práticas, mas contribui para pensá-las no ciberespaço.

Por fim, as comunidades virtuais de aprendizagem baseadas na construção de conhecimento, embora semelhantes às anteriores, visam produzir conhecimento a partir de discussão sobre a prática. Rodríguez Illera explica que essa distinção entre as comunidades de aprendizagem é elaborada focando-se as tarefas ou os objetivos de aprendizagem do grupo, o sentimento de pertencimento a ele, as estruturas de participação e os mecanismos de crescimento e reprodução - critérios, portanto, funcionais.

Hakkarainen et al (2004, apud RODRÍGUEZ ILLERA, 2007) também levantaram diferentes tipos de modalidades entre as comunidades virtuais de aprendizagem. Mas, neste caso, os critérios foram a participação e os objetivos dos participantes. Assim, os autores distinguem as comunidades que "procuram a aquisição de conhecimento, participam ativamente, ou, por fim, criam conhecimento novo conjuntamente com outros participantes" (2007, p. 120). Tal abordagem enfatiza a análise das comunidades virtuais em ambientes intencionalmente educativos, mas direcionando a construção do conhecimento de forma colaborativa e reflexiva entre os integrantes.

\footnotetext{
${ }^{36}$ Para melhor compreensão, reproduzimos aqui a nota inserida por Illera a respeito de tal afirmação: "Verificarse-á que utilizamos 'experiência' no sentido de Dewey, retomado por Illeris, e reservamos 'prática' para a designação tanto da forma concreta da experiência, como do campo de conhecimento/ação que alicerça o interesse comum de uma comunidade de prática".
} 
Como vemos, há muitas definições e "subcomunidades" virtuais de aprendizagem. Paloff e Pratt (2002), autores muito estudados pelas pessoas que conhecemos da área de Educação e Tecnologia, não apresentam uma definição para esse tipo de comunidade, se assim podemos classificar. Para os autores, cabe àqueles que se envolvem com o uso da tecnologia na Educação tal definição, até porque o modo como o meio eletrônico será utilizado depende das "necessidades humanas", de professores e de alunos, razão pela qual fazem surgir as próprias comunidades.

No entanto, Palloff e Pratt (2002) são enfáticos ao defenderem que a EaD online pode atingir seus objetivos mais eficientemente por meio da construção de uma comunidade. "A comunidade é o veículo através do qual ocorre a aprendizagem online" (p. 53). Sem proporcionar e estimular a construção de uma comunidade, muitos cursos pesquisados pelos autores desde 1993 não conseguiram atingir seus propósitos.

(...) fundamentais aos processos de aprendizagem são as interações entre os próprios estudantes, as interações entre os professores e os estudantes e a colaboração na aprendizagem que resulta de tais interações. Em outras palavras, a formação de uma comunidade de alunos, por meio da qual o conhecimento seja transmitido e os significados sejam criados conjuntamente, prepara o terreno para bons resultados na aprendizagem. (PALOFF e PRATT, 2002, p. 27, grifo nosso).

A freqüente colaboração entre os participantes sob a experiência da aprendizagem seria uma característica das comunidades virtuais de aprendizagem, somada ao compromisso nem sempre explícito desenvolvido entre os participantes. No entanto, nem sempre ela aparece nas definições de todos esses autores - algumas delas, inclusive, se encaixariam em nosso entendimento de rede de aprendizagem online.

Encontrar limites "separatistas" entre rede e comunidade não é nosso objetivo, mas, sim, conhecer melhor esses objetos. As definições contribuem para pensarmos o que acontece nas redes e comunidades de aprendizagem. Mas para nós, seria difícil adotar, por exemplo, o conceito de Hakkarainen et al porque acreditamos que aquisição, participação e construção de conhecimento estão intrinsecamente ligadas, não sendo possível fazer tal separação. Da mesma forma, tarefas, práticas e construção de conhecimento - "tipos" de comunidades virtuais de aprendizagem estabelecidas por Riel e Polin (2004) - poderiam ser encontradas em uma mesma comunidade. 


\subsection{Colaboração e cooperação}

Freqüentemente, colaboração e cooperação confundem-se por suas similaridades. De fato, são conceitos complexos, definidos de acordo com a abordagem. No âmbito da aprendizagem, o processo de colaboração pode ser entendido, de acordo com os autores abaixo destacados:

- a aprendizagem colaborativa é uma filosofia de ensino, não apenas como técnica em sala de aula; ela sugere uma maneira de lidar com as pessoas por meio do respeito, como um modo de viver e lidar com outras pessoas. (PANITZ apud BARBOSA, 2008, p. 73).

- o trabalho colaborativo depende de cooperação entre os membros da equipe; por conseguinte, uma subordinação da colaboração à cooperação. (CORD apud BARBOSA, 2008, p. 73).

Já a cooperação:

- é uma estrutura de interação projetada para facilitar a realização de um objetivo ou produto final. (PANITZ, apud BARBOSA, 2008, p. 73).

Entre os pesquisadores que diferenciam a cooperação e a colaboração pelo modo como a tarefa do grupo é organizada, a aprendizagem cooperativa pode ser entendida por um viés mais técnico:

- a cooperação apresenta-se como um conjunto de técnicas e processos que grupos de indivíduos aplicam para a concretização de um objetivo final ou a realização de uma tarefa específica. É um processo mais direcionado do que o processo de colaboração e mais controlado pelo professor. (PANITZ, apud BARBOSA, 2008, p.74).

- na cooperação, a estrutura hierárquica prevalece e cada um dos membros da equipe é responsável por uma parte da tarefa. A coordenação nas atividades cooperativas é apenas obrigatória na montagem dos resultados parciais. (DILLENBOURG et al., apud BARBOSA, 2008, p.74).

Após levantamento bibliográfico, Barbosa (2008) observou que tanto a colaboração quanto a cooperação designam atividades de grupos para atingir um objetivo. A diferença estaria na regularidade da troca, na organização do trabalho e na coordenação. A seguir, a pesquisadora apresenta uma comparação a partir de sua investigação: 


\begin{abstract}
Abordagem colaborativa
Característica conceitual

Concepção

Estruturação

Foco

Forma de organização

Prescrição de atividades

Filosofia de ensino: engloba questões teóricas, políticas e filosóficas.

Promove a "aculturação" dos alunos nas comunidades de conhecimento.

Compartilhamento de autoridade e aceitação de responsabilidades entre os membros, nas ações do grupo.

Processo mais aberto, com um papel mais ativo do aluno.

Compromisso mútuo dos participantes num esforço coordenado, visando à conclusão de um problema.

Atividade sincronizada, resultado de um esforço continuado de construir e manter uma concepção compartilhada de um problema.

Abordagem cooperativa

Técnica de trabalho: estrutura de interação projetada para facilitar a realização de um objetivo ou produto final.

Aumenta as habilidades cognitivas e sociais por meio de um conjunto de técnicas aprendidas.

Estrutura hierárquica em um processo mais direcionado pelo professor.

Processo centrado no professor e controlado por ele.

Cada um é responsável pelo

desenvolvimento de uma parte do problema.

Segue uma série de etapas com normas bem definidas.

Quadro 4: Comparação entre abordagens colaborativa e cooperativa Fonte: BARBOSA, 2008, p. 75

Em comunidade, encontraríamos características apontadas pela abordagem colaborativa como o compromisso mútuo dos participantes, o compartilhamento de responsabilidades e de autoridade - embora exista a presença do professor.

Assumimos a colaboração, e não a cooperação, como elemento distintivo das comunidades virtuais em relação às redes - que podem apresentar colaboração, mas em menor frequiência - baseados na revisão bibliográfica de Barbosa (2008), que revela o caráter coletivo e sincronizado da ação.
\end{abstract}

\subsection{A comunidade virtual de aprendizagem EAV 1}

Entre os meses de março e junho de 2008, participei da disciplina "Ensinando em Ambientes Virtuais I" - EAV 1 (EDM 5044-2-1), curso oferecido pelo Programa de PósGraduação da Faculdade de Educação da Universidade de São Paulo aos pós-graduandos da USP e ministrado pela Prof ${ }^{a}$. Dra ${ }^{a}$. Vani Moreira Kenski.

A disciplina semi-presencial foi de fundamental importância para o desenvolvimento desta dissertação. Por um lado, contribuiu com nosso referencial teórico e me permitiu vivenciar dinâmicas colaborativas por meio de um curso online. Por outro, transformou-se em objeto de análise desta investigação. 
O exame deve-se ao fato de que seus integrantes teriam constituído uma comunidade virtual de aprendizagem no decorrer do processo. Descobrir os elementos que teriam proporcionado essa formação tornou-se um objetivo, acreditando que uma reflexão poderia contribuir com o entendimento do nosso objeto de pesquisa, além de somar-se a outras investigações sobre o tema. A análise passa a ser apresentada a partir de dois olhares:

a)

desta aluna-pesquisadora, que participou da disciplina e examina a formação de comunidade(s) a partir da vivência no curso e do referencial teórico norteador da pesquisa, além de apontar indicadores dessa formação após exame de mensagens retiradas de fóruns da EAV1;

b) da professora do curso, Vani Kenski, e dos tutores, por meio de entrevista e questionários, que revelam os bastidores do curso e o esforço para constituição de comunidade(s) de aprendizagem online.

Seria importante ressaltar que a entrevista com a professora e a aplicação de questionário aos tutores ocorreu após análise da comunidade e redação do olhar da alunapesquisadora, para que as considerações dos pesquisados não interferissem na interpretação dos dados.

O curso EAV 1 reuniu 31 alunos em torno de uma proposta colaborativa para que, em rede, eles aprendessem a ensinar em ambientes virtuais. Durante três meses, mais de mil e quinhentas mensagens foram trocadas nos fóruns, conforme os números levantados pela professora e tutores.

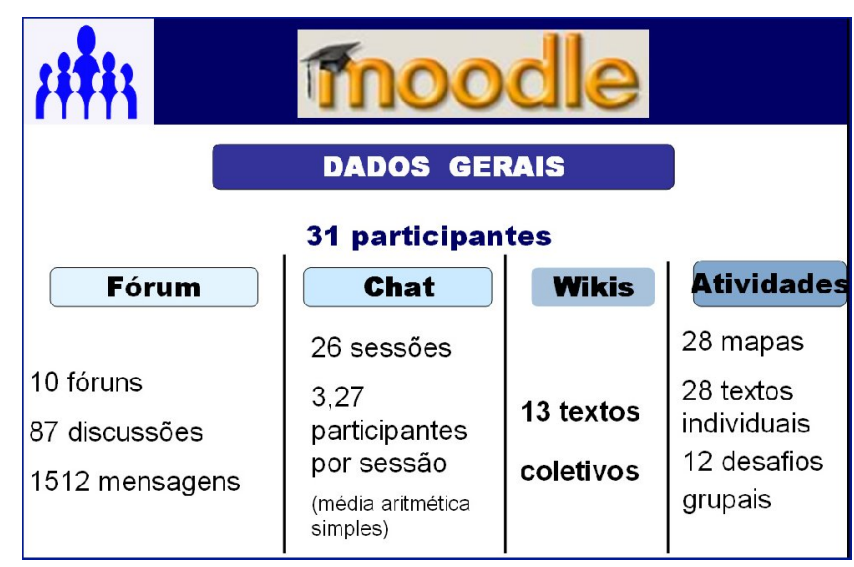

Figura 15: Dados gerais do curso EAV 1

Fonte: Slide produzido por Kenski, Gozzi, Silva e Jordão 
Realizado em três ambientes online, o curso contava com apenas quatro encontros presenciais que eram mais interações sociais, sem proporcionar aprendizado teórico, este construído a partir dos processos desencadeados no ciberespaço. A disciplina pretendia alcançar os seguintes objetivos, divulgados em sua ementa:

- Refletir sobre as possibilidades e limites oferecidos pelas tecnologias digitais de comunicação e informação para a educação na sociedade contemporânea;

- Vivenciar um modelo de "comunidade virtual" orientada para o desenvolvimento de aprendizagens colaborativas online. (Negrito nosso);

- Posicionar-se criticamente diante das novas formas de ensino online;

- Elaborar projetos educacionais colaborativos que possam ser oferecidos em ambientes virtuais online.

O embasamento teórico do curso fundamenta uma proposta colaborativa de aprendizagem em cursos online. Planejado para ser realizado a distância, um dos objetivos implícitos seria mostrar a possibilidade de uma Educação online de qualidade.

A disciplina foi estruturada em três unidades (na tabela, a seguir, chamadas de temas): Tecnologias, Ensino e Projetos, além da $1^{\mathrm{a}}$. semana de ambientação online.

\begin{tabular}{|c|c|c|c|c|}
\hline \multicolumn{5}{|c|}{ PROGRAMA E CRONOGRAMA } \\
\hline $\begin{array}{l}\text { Temas } \\
\text { 1. AMBIENTAÇÃO } \\
\text { 2. TECNOLOGIA. } \\
\text { 2. ENSINO. } \\
\text { 3. PROJ ETO. }\end{array}$ & $\begin{array}{l}\text { Datas } \\
11 / 03 \\
18 / 03 \mathrm{~A} \\
08 / 04 \mathrm{~A} \\
20 / 05 \mathrm{~A}\end{array}$ & & 44 & $\begin{array}{l}\text { Atenção ! } \\
\text { Todas as aulas } \\
\text { começam às } 14 \\
\text { horas da terça- } \\
\text { feira. }\end{array}$ \\
\hline Aulas Presenciais & $11 / 03$ & $08 / 04$ & $13 / 05$ & $17 / 06$ \\
\hline
\end{tabular}

Figura 16: Programa e cronograma do curso EAV 1

Fonte: Parte de slide disponibilizado no ambiente da SITE Educacional

Cada unidade era composta por temas desenvolvidos por meio de atividades

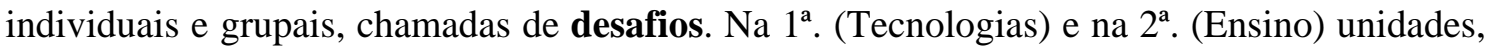
os alunos distribuíram-se em grupos para a realização dos desafios, embora também participassem de atividades que envolviam todos os alunos do curso.

$\mathrm{Na} 3^{\mathrm{a}}$. unidade (Projeto), como os alunos deveriam desenvolver um projeto de ensino online, a formação de grupos foi opcional. Esta aluna-pesquisadora, por exemplo, produziu individualmente a proposta, uma vez que ela seria incorporada a esta dissertação. Trata-se da rede "Comunidade de Gestores", apresentada no capítulo 2. 


\begin{tabular}{|c|c|c|}
\hline TEMAS & OBJ ETI VO & ATI VI DADES \\
\hline $\begin{array}{l}\text { AMBI ENTAÇÃO } \\
\text { ON LI NE }\end{array}$ & $\begin{array}{l}\text { Ambientação dos } \\
\text { alunos no LMS e } \\
\text { no curso. }\end{array}$ & $\begin{array}{l}\text { 1. Apresentação Pessoal } \\
\text { 2. Netiqueta } \\
\text { 3. Identidade grupal } \\
\end{array}$ \\
\hline $\begin{array}{l}\text { TECNOLOGI A } \\
\text { - O que são TICs? } \\
\text { - Ambientes Virtuais } \\
\text { - Hipertextos e Mapas Conceituais }\end{array}$ & $\begin{array}{l}\text { Caracterização } \\
\text { da Internet como } \\
\text { espaço de síntese } \\
\text { hipermediático. }\end{array}$ & $\begin{array}{l}\text { 1. Leitura de textos } \\
\text { 2. Desafios individuais e coletivos. } \\
\text { 3. Elaboração de mapas conceituais. }\end{array}$ \\
\hline $\begin{array}{l}\text { ENSI NO } \\
\text { - Modalidades } \\
\text { - Ensino colaborativo } \\
\text { - Comunidades Virtuais }\end{array}$ & $\begin{array}{l}\text { Conceituação de } \\
\text { tipos e } \\
\text { modalidades de } \\
\text { ensino on-line. }\end{array}$ & $\begin{array}{l}\text { 1. Leitura dos textos. } \\
\text { 2. Desafios individuais e grupais. } \\
\text { 3. Identificação de possibilidades pedagógicas } \\
\text { dos LMSs. }\end{array}$ \\
\hline PROJ ETO & $\begin{array}{l}\text { Elaboração de } \\
\text { pré-projeto de } \\
\text { ensino online. }\end{array}$ & $\begin{array}{l}\text { 1. Leituras dos textos } \\
\text { 2. Desafios individuais e grupais. } \\
\text { 3. Elaboração de pré-projeto de ensino on-line. }\end{array}$ \\
\hline
\end{tabular}

Figura 17: Temas, objetivos e atividades do curso EAV 1

Fonte: Parte de slide disponibilizado no ambiente da SITE Educacional

A ambientação online e a $1^{\text {a }}$. unidade (Tecnologias) foram vivenciadas em um ambiente hospedado e desenvolvido pela SITE Educacional ${ }^{37}$ na plataforma Moodle ${ }^{38}$.

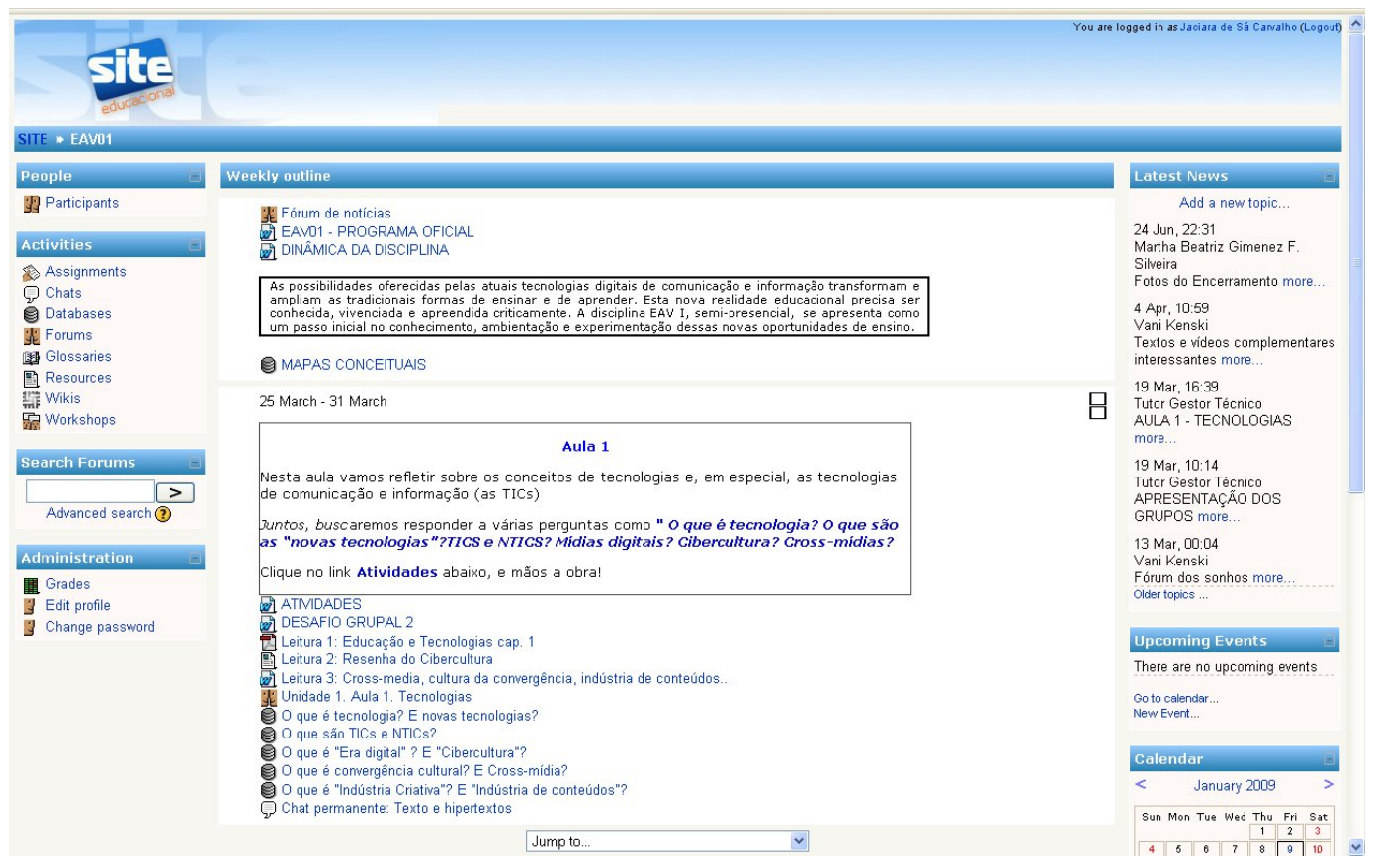

Figura 18: Homepage do ambiente da SITE Educacional (Moodle)

Fonte: Reprodução

\footnotetext{
${ }^{37}$ Disponível em 〈http://www.siteeducacional.com.br/moodle/course/view.php?id=5〉. Acesso em 20 mai. 2008.

38 “Modular Object-Oriented Dynamic Learning Environment - Moodle é um software livre, de apoio à aprendizagem, executado num ambiente virtual. A expressão designa ainda o Learning Management System (Sistema de Gestão da Aprendizagem) em trabalho colaborativo baseado nesse programa", de acordo com informações disponíveis em 〈http://pt.wikipedia.org/wiki/Moodle〉. Outras informações também podem ser obtidas em: <http://moodle.org/>. Os sites foram acessados em 27 mai. 2008.
} 
Quando já havíamos nos adaptado ao ambiente virtual da SITE e ao grupo de alunos a que pertencíamos, o curso provocou uma ruptura, obrigando-nos a migrar para outro ambiente, o TelEduc ${ }^{39}$, e a mudar de grupo - era chegada a $2^{\text {a }}$. unidade (Ensino).

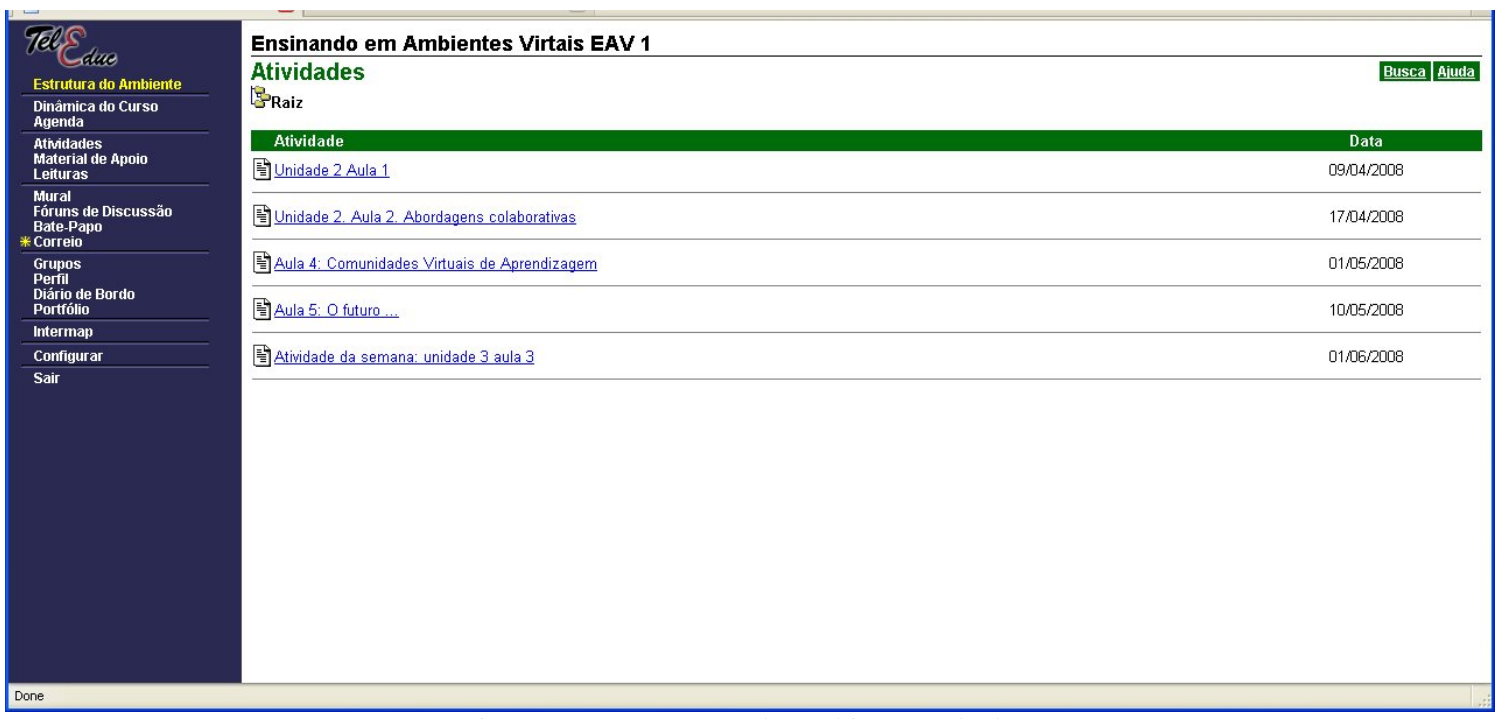

Figura 19: Homepage do ambiente TelEduc

Fonte: Reprodução

$\mathrm{Na} 3^{\mathrm{a}}$. unidade (Projeto), trocamos novamente de ambiente virtual. Fomos para o "LabSpace", mais exatamente a "CoLearn" "40, também desenvolvido na plataforma Moodle, embora tivéssemos liberdade para usar, ao mesmo tempo, os outros dois ambientes para realizar as atividades e elaborar o projeto, aproveitando o que há de melhor em cada um.

\footnotetext{
39 “O TelEduc é um ambiente para a criação, participação e administração de cursos na Web. Ele foi concebido tendo como alvo o processo de formação de professores para informática educativa, baseado na metodologia de formação contextualizada desenvolvida por pesquisadores do Nied (Núcleo de Informática Aplicada à Educação) da Unicamp", segundo informações disponíveis em: 〈http://www.teleduc.org.br/>. Acesso em 10 mai. 2008. O endereço do curso no TelEduc é o seguinte: 〈http://ip.netup.com/teleduc/cursos/aplic/index.php?cod_curso=15 $>$. ${ }^{40}$ CoLearn é a Comunidade de Pesquisa sobre Tecnologias Educacionais, onde parte do curso EAV1 foi dado, baseado na plataforma Moodle. Endereço: <http://labspace.open.ac.uk/course/view.php?id=3313\&loginguest=true>. A CoLearn fica dentro de um laboratório virtual chamado OpenLearn LabSpace que oferece ambiente para a constituição de comunidades virtuais de aprendizagem dentro da Open University (OU) - a universidade dedicada a Educação a Distância do Reino Unido.
} 


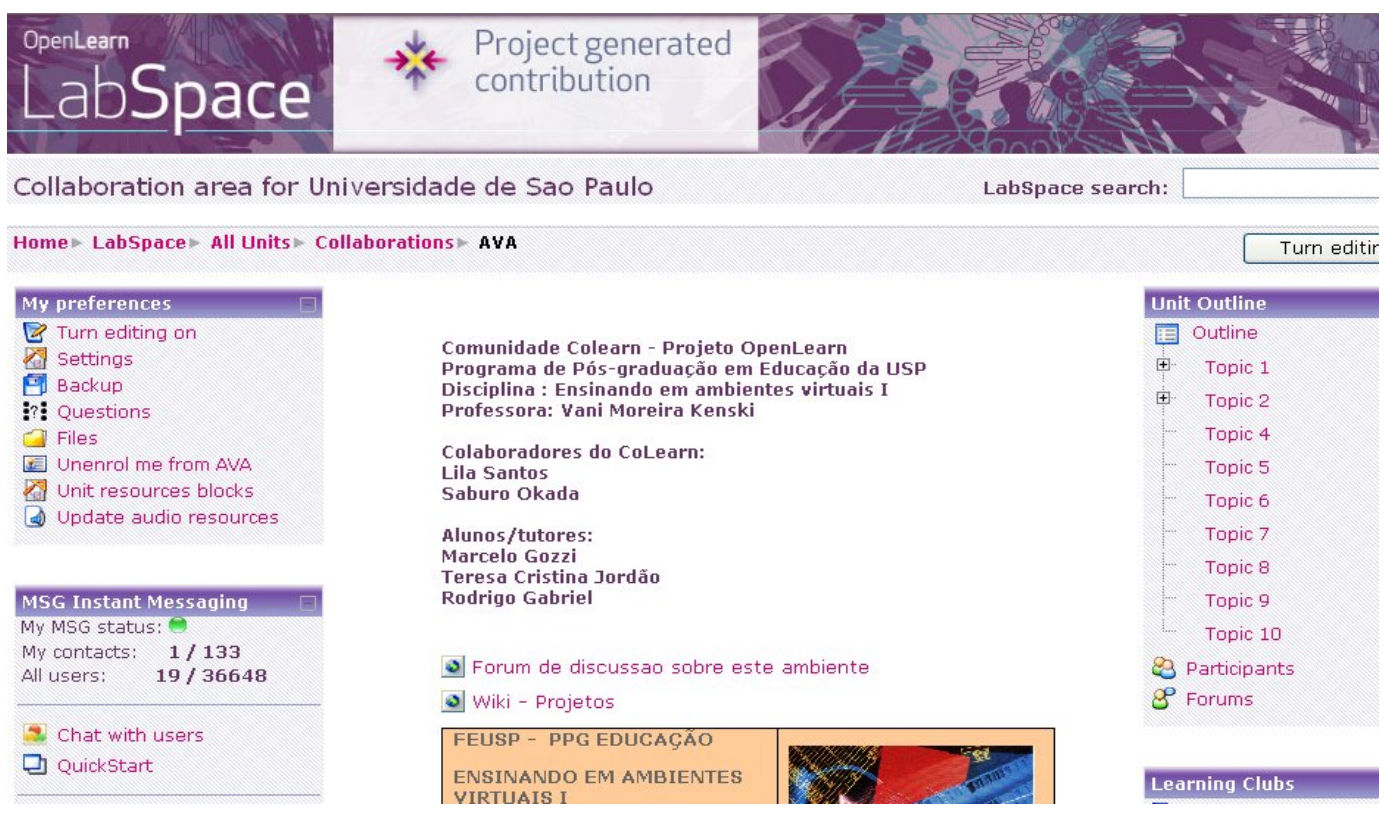

Figura 20: Homepage do ambiente LabSpace/CoLearn (Moodle)

Fonte: Reprodução

Nos grupos, a cada semana um dos integrantes era eleito "líder" para motivar a participação e, principalmente, estimular a colaboração para a realização dos desafios. Essa foi uma estratégia definida pela professora do curso dentro da proposta metodológica adotada, baseada nas abordagens cooperativas e colaborativas de ensino.

\begin{tabular}{|c|c|c|c|}
\hline \multicolumn{4}{|l|}{ METODOLOGI A } \\
\hline $\begin{array}{c}\text { A metodologia da } \\
\text { disciplina baseia-se nas } \\
\text { abordagens } \\
\text { cooperativas e } \\
\text { colaborativas de ensino. }\end{array}$ & $\begin{array}{l}\text { Estamos construindo a } \\
\text { nossa "webness", ou seja, } \\
\text { o "entorno vivo de } \\
\text { inteligências humanas } \\
\text { conectadas que trabalham } \\
\text { em muitas coisas que } \\
\text { sempre tem relevância } \\
\text { para todos os demais." }\end{array}$ & $\begin{array}{l}\text { Teremos } \\
\text { atividades } \\
\text { e desafios } \\
\text { individuais } \\
\text { e grupais. }\end{array}$ & $\begin{array}{c}\text { Todos participam } \\
\text { ativamente das } \\
\text { atividades e propõem } \\
\text { novos caminhos que } \\
\text { possibilitem a melhor } \\
\text { aprendizagem de } \\
\text { todos. }\end{array}$ \\
\hline
\end{tabular}

Figura 21: Metodologia do curso

Fonte: Parte de slide disponibilizado no ambiente da SITE Educacional

Os alunos foram avaliados durante todo o processo de aprendizagem, principalmente quanto às posturas colaborativas e à atuação nos grupos. Também apresentavam autoavaliações que eram consideradas pelo professor e podiam ser vistas pelos colegas, caso o participante permitisse. 


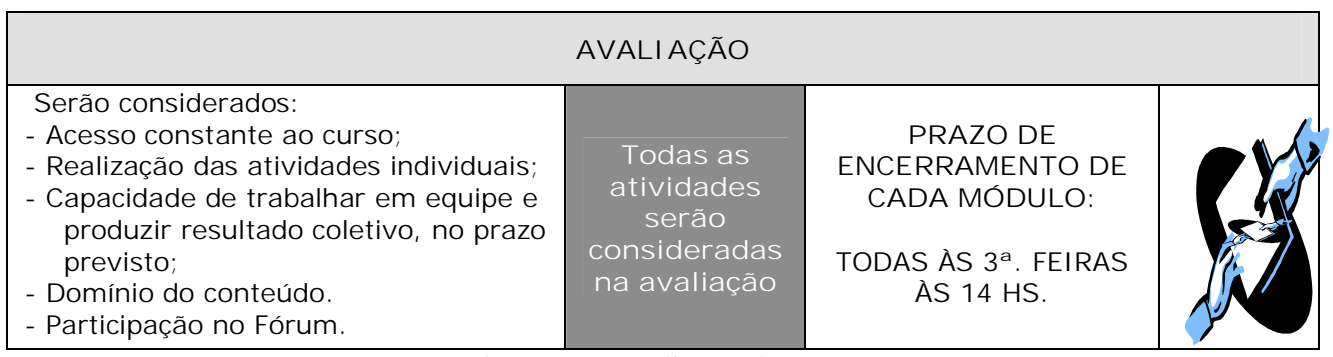

Figura 22: Avaliação do curso

Fonte: Parte de slide disponibilizado no ambiente da SITE Educacional

\subsubsection{Olhar da aluna-pesquisadora}

Nesta dissertação, temos a preocupação de distinguir rede de aprendizagem online e comunidade virtual de aprendizagem e, portanto, não poderíamos deixar de fazê-lo quanto ao curso em questão. Afinal, nosso objeto de pesquisa envolve justamente essa distinção, além de distinguir as de aprendizagem em relação às demais redes e comunidades do ciberespaço.

Entendemos que rede e comunidade se diferenciam pela intensidade das relações estabelecidas entre seus integrantes. Ambas reúnem participantes em torno de um interesse comum - o de aprender. Mas nas comunidades, os laços entre as pessoas seriam mais estreitos, fruto da convivência, de constantes interações. Essa freqüência pode desencadear um compromisso com o outro, com a aprendizagem daquele que faz parte da mesma comunidade. E, sendo induzida ou não, ações colaborativas e/ou cooperativas acabariam por se desenvolver. A constância em agir colaborativamente e/ou cooperativamente, assim como o compromisso, seriam, para nós, características distintivas das comunidades virtuais.

Alguns autores enfatizam a colaboração como elemento fundamental na constituição de comunidades virtuais. Como visto anteriormente, Lévy (1999, p.27) acredita que uma comunidade virtual se constrói "por meio de cooperação ou de troca, independentemente das proximidades geográficas e das filiações institucionais".

Paloff e Pratt (2002) consideram que, em ambientes virtuais, a Educação online tem mais chances de alcançar os objetivos propostos quando consegue fazer surgir uma comunidade, na qual as interações e "a colaboração na aprendizagem que resulta de tais interações" (p. 27) preparam o terreno para bons resultados.

Acreditamos que o curso EAV 1 começou com características de uma rede de aprendizagem online. Vale lembrar o entendimento que construímos a respeito: 
As redes de aprendizagem online são agrupamentos localizados no ciberespaço que apresentam características de um processo de ensino: objetivo educativo explícito, planejamento inicial e um ou mais professores entre os integrantes da rede, que só existe e se mantém se houver interação e abertura para que os participantes influenciem os processos.

No início do curso, os alunos estavam se conhecendo e adquirindo confiança por meio das atividades propostas. A grande maioria entrava em ambiente virtual de aprendizagem pela primeira vez, enfrentando não apenas a novidade tecnológica, mas também o ritmo específico daquele curso online, bastante intenso. Eles contaram com a ajuda de alunos mais experientes, principalmente os colegas do grupo em que estavam. E, assim, interagindo para vencer esses e os desafios propostos pela professora, formaram uma rede de aprendizagem online.

Com a vivência em rede, os laços foram se estreitando e os integrantes do curso passaram a colaborar e/ou cooperar com a aprendizagem do outro de forma mais freqüente e compromissada - embora esse não seja um destino das redes de aprendizagem. A rede, então, se transformava em comunidade.

Acreditamos que a maior parte do crédito quanto ao desenvolvimento da colaboração deve ser dada à metodologia adotada pela responsável pelo curso. As atividades seguiram abordagens colaborativas de ensino porque, em nosso entendimento, teriam estimulado o envolvimento de todos os participantes na realização das ações, evitando divisão de tarefas e orientando para que elas fossem realizadas de forma sincronizada. Embora cada grupo tivesse uma liderança semanal, a autoridade era compartilhada entre os integrantes, que tiveram papéis ativos e desenvolveram ações coordenadas para concluir os desafios.

Em artigo (CARVALHO et al., 2008), esta aluna-pesquisadora e alguns colegas avaliamos que o curso "EAV 1":

- Promoveu o estabelecimento de relações sociais entre os participantes do curso, favorecidas pelas possibilidades de interação a partir de interesses comuns;

- Desenvolveu o sentimento de pertencer a uma comunidade, manifestado pela permanência dos participantes;

- Proporcionou o desenvolvimento de diversos projetos colaborativos;

- Despertou entre os participantes o sentimento de co-responsabilidade pelo aprendizado e pelos resultados dos projetos desenvolvidos.

Enfim, o curso teria conseguido a difícil tarefa de desenvolver uma comunidade de aprendizagem entre seus alunos. Trabalhamos com a idéia de que comunidade é um "campo simbólico em que se desenvolvem territorialidades e temporalidades específicas que nos 
permitem conceber o nosso próximo numa teia intersubjetiva de reciprocidades" (SANTOS, 2000, p.81).

Kenski, em aula presencial, comentou que sua experiência a levava a acreditar que, nos cursos online, há momentos em que os membros se comportam mais como uma comunidade do que em outros. A professora citou, como exemplo, a movimentação de um dos grupos de que fiz parte: em dois dias, corremos para finalizar um texto coletivo e enviá-lo à Associação Brasileira de Educação a Distância (ABED). Graças ao nosso esforço colaborativo, o artigo "Comunidades de Aprendizagem - Uma Vivência no Ensino de PósGraduação" foi apresentado no "14". Congresso Internacional ABED de Educação a Distância”, realizado em setembro de 2008.

Há momentos em que a união e a colaboração são maiores do que em outros. Mas acredito que, de modo geral, os alunos do curso "EAV I" conseguiram desenvolver um "campo simbólico", sentindo-se em uma "teia intersubjetiva de reciprocidade" (Santos, 2000, p. 81), e colaborando uns com os outros na maior parte do curso.

Ao longo de minha participação na disciplina, percebi o desenvolvimento dessa comunidade, mas também o surgimento de algumas subcomunidades. Participantes com mais afinidades entre si e que ofereceram ajuda mais para uns do que para outros, independente do grupo a que pertenciam, acabaram constituindo subcomunidades.

Eu podia contar com as pessoas de minha subcomunidade, mesmo que elas não estivessem no grupo a que eu pertencia. Com elas, construí laços mais estreitos durante atividades distintas, grupais ou individuais, em ferramentas variadas, e, algumas vezes, não ficando restritas aos ambientes virtuais da disciplina - algumas vezes nos comunicávamos por meio de ferramentas como o MSN e e-mails pessoais.

A solidariedade e o preocupar-se com o outro foram elementos determinantes para a constituição de subcomunidades. Vale ressaltar que, apesar dos alunos constituírem subcomunidades, a comunidade "EAV1" permanecia por conta da realização de atividades que reuniam todos os participantes, indistintamente.

O sentimento de pertencimento, como um sentido de ligação, é apontado por Palácios (1998) como um dos elementos de uma comunidade virtual. Sentir-se parte de uma comunidade trata-se de algo pessoal, íntimo, embora a partir de uma relação interpessoal. Palácios trata da eletividade como uma característica do pertencimento a uma comunidade virtual: "[...] o indivíduo só pertence se, quando e por quanto tempo estiver, efetivamente, interessado em fazê-lo" (PALACIOS, 1998). 
Kenski (2001) ressalta que a motivação para aprender está ligada aos anseios e desejos pessoais de cada um, embora a sensação de estar entre pessoas com os mesmos interesses, com quem se pode trocar idéias e aprender já é "potencialmente motivador". No entanto, o contexto social não "define ou restringe" a motivação individual. O estímulo para aprender em comunidade ao longo do tempo é um desafio, visto que as motivações pessoais podem ser reorientadas durante a aprendizagem - "motivação é processo".

Ainda segundo Kenski (2001), “o processo motivacional individual inclui necessidades, expectativas, valores, modelos mentais e as concepções pessoais sobre tudo, o significado que atribuímos ao trabalho... e ao estado permanente de predisposição para aprender". Assim, é possível entender porque vimos, durante o curso, colegas muito participativos em alguns momentos e em outros quase ausentes.

Mas como o comportamento em comunidade virtual também resulta de motivações sociais, os membros de uma comunidade precisam sentir-se acolhidos e reconhecidos pelos demais. A motivação "provocada" pelo outro pode levar os participantes a superar um eventual afastamento da aprendizagem em rede, advinda de motivações pessoais.

\footnotetext{
Participando, colaborando, reconhecendo e sendo reconhecido pelos seus pares, a pessoa que atua intensamente na comunidade virtual sente o seu poder, desenvolve suas potencialidades comunicacionais, libera seus talentos. Mais ainda, socialmente integrada na equipe, a pessoa dimensiona sua participação de acordo com os valores e regras em jogo, realiza trocas e aprende muito mais do que o foco específico de seu interesse. Aprende a conviver em grupo, a colaborar e respeitar as pessoas, a falar e a ouvir (ainda que ambos ocorram em intercâmbios escritos), a superar conflitos, expor opiniões, trabalhar com pessoas que não conhece presencialmente, mas com as quais se identifica no plano dos interesses e idéias. (KENSKI, 2001)
}

Os diferentes ambientes virtuais utilizados no curso também influenciaram as motivações dos alunos. Os fóruns criados a partir da plataforma Moodle, por exemplo, estimulavam a leitura e o envio de mensagens porque não era preciso clicar em cada post para ler e responder. Todas as mensagens enviadas, assim como as respostas, eram mostradas na mesma tela. A exibição da foto do participante junto à mensagem também contribuía para estreitar os laços, já que havia o reconhecimento da imagem do colega. 


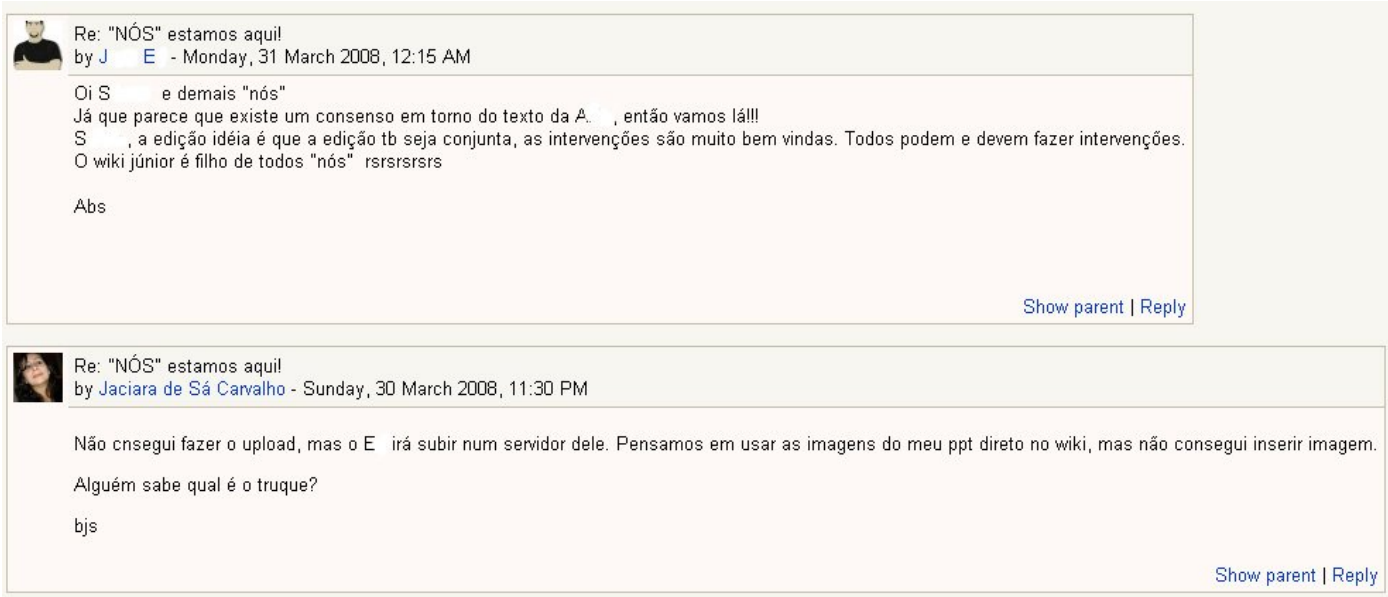

Figura 23: Mensagens de fórum da plataforma Moodle Fonte: Reprodução

Já no ambiente TelEduc, era preciso clicar no título de cada mensagem para ler e responder, diminuindo o estímulo à participação, conforme avaliação dos alunos. Além disso, a imagem do participante não aparece ao lado da mensagem.

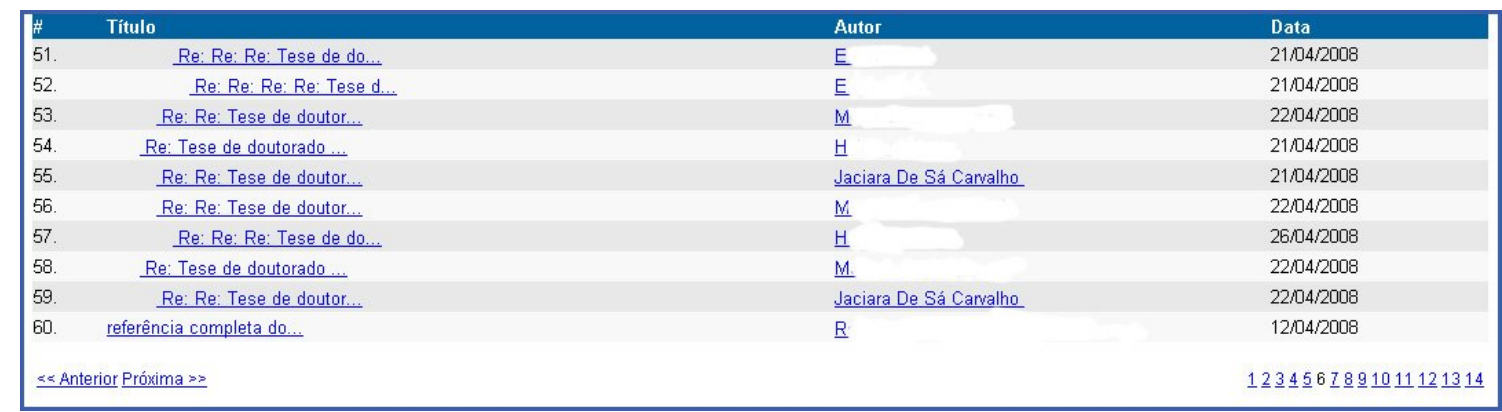

Figura 24: Títulos das mensagens de Fórum da plataforma TelEduc

Fonte: Reprodução

A reprodução acima é do fórum "Teorias de aprendizagem e ambientes virtuais", no qual os alunos discutiram a relação entre o ambiente online e a aprendizagem, entendendo que cada ambiente reflete a concepção de Educação de seus criadores e interfere na estruturação do processo educacional.

Enquanto houve interesse e disposição para colaborar, as pessoas permaneceram em comunidade. Como a proposta final do curso poderia ser elaborada individualmente ou em grupo, optei por desenvolvê-la sozinha porque seria incorporada a esta dissertação. Naquele momento, a comunidade EAV se desfez para mim. 
Embora os tutores do curso estimulassem a contribuição dos participantes na elaboração das propostas dos demais, era final de semestre e a maioria dos alunos acabou concentrando-se em sua própria proposta ou de seu grupo. A comunidade tornou-se, então, uma rede de aprendizagem, mais fluída, que continha em si comunidades (os grupos) que elaboraram o projeto final do curso.

Uma comunidade existe enquanto seus membros desejam permanecer juntos, colaborando. Ao fim da disciplina, até mesmo a rede de aprendizagem se desfez. Mas, alguns meses depois, esta pesquisadora e alguns colegas com quem constitui laços mais estreitos, voltamos a compor um grupo de estudos, mantendo o mesmo nome, o "Grupo Nós", embora com nova composição. A essência da comunidade EAV1 permanecia em "Nós."

\section{Indicadores de formação de uma CVA}

A disciplina "Ensinando em Ambientes Virtuais 1" (EAV 1) é apresentada como exemplo de comunidade virtual de aprendizagem (CVA) nesta dissertação. O entendimento resulta, principalmente, da análise do conteúdo das mensagens enviadas a fóruns do curso, além da experiência de ter participado do curso. Nos fóruns, as trocas podem ser examinadas, uma vez que ao ler as mensagens dos colegas, os demais enviavam suas considerações contribuindo para a construção de conhecimento de todos - uma ação individual, mas realizada a partir do coletivo.

Esta investigação indica que uma comunidade se caracteriza pelo alto grau de proximidade e de colaboração entre seus membros. A partir desse entendimento, perguntamo-nos como identificar a formação de uma comunidade virtual em uma situação educativa explícita, em uma rede de aprendizagem. Alguns elementos foram mapeados.

\section{A reciprocidade permanente, o compromisso implícito, a iniciativa, a} informalidade e, principalmente, a colaboração entre os participantes e a intervenção pontual do professor nas atividades seriam indicadores de constituição de comunidade em uma situação de aprendizagem em rede, a partir da análise do curso "EAV 1".

Ao mapear esses indícios, nosso objetivo foi entender melhor o objeto de pesquisa. Mas também contribuir para que os educadores possam ter uma consciência maior da situação de um grupo em contexto virtual e, se o objetivo deles for a constituição de comunidade, elaborar estratégias para fomentar tais indicadores. 
Alguns indícios também são encontrados na pesquisa de doutorado de Barbosa (2008) a respeito dos fatores que interferem na dinâmica de colaboração online em processos educacionais desencadeados em cursos via Internet. A pesquisadora identifica elementos que constituiriam os fundamentos das dinâmicas colaborativas de uma comunidade virtual de aprendizagem, agrupando-os em cinco categorias:

\section{Infra-estrutura tecnológica}

- Interatividade: Habilidade com as ferramentas informáticas; adequação das ferramentas às atividades (softwares de texto coletivo);

- Acessibilidade: Eficácia do sistema;

- Sala de aula virtual: Utilização de espaço específico (AVA).

\section{Posturas individuais}

- Apresentação: Perfil de alunos e professores;

- Comprometimento e responsabilidade: Comprometimento com o curso, comprometimento com os colegas, cumprimento das tarefas, formação contínua, leitura prévia dos materiais didáticos, pesquisa, reflexão, respeito aos prazos, responsabilidade com os trabalhos, seriedade na realização das atividades;

\section{- Disciplina;}

- Autonomia: Auto-aprendizagem, auto-avaliação, estruturação do processo de aprendizagem, independência, planejamento do estudo;

- Habilidades relacionadas à tomada de decisão por meio de leitura e escrita: Análise e síntese, interpretação, argumentação, criatividade, descontração, desenvoltura, expressão de idéias, extroversão, liderança, organização de idéias, ousadia, pragmatismo, segurança, solução de problemas, trabalho em grupo;

- Envolvimento: Assiduidade, atenção às atividades, concentração, constância, dedicação, dinamismo, disponibilidade, empenho para superar obstáculos e dificuldades, entusiasmo, iniciativa, interesse, participação ativa nas atividades, persistência na busca por resultados positivos, prazer, predisposição, realização de tarefas da melhor forma possível;

- Afetividade: Atenção aos colegas, compreensão do outro, desenvolvimento de laços de amizade, expressão de interesses e sentimentos, receptividade, solidariedade.

\section{Posturas coletivas}

- Interação por meio de leitura e escrita: Processos coletivos de enunciação, comunicação constante, intercâmbio do grupo, entrosamento, compartilhamento de idéias e atividades, socialização de conhecimentos, compartilhamento de informações, troca de experiências, debates, troca de impressões e opiniões, construção coletiva de conhecimento;

- Trabalho em equipe: Aceitação da decisão da maioria, acompanhamento do ritmo do grupo, colaboração, cooperação, consenso, cumplicidade, democracia, divisão de tarefas, espírito de equipe, liberdade de expressão, negociação, objetividade, organização do grupo, organização do tempo, planejamento do desenvolvimento das atividades, produtividade;

- Sociabilidade: Aceitação das diversidades, apoio mútuo, bom humor, coleguismo, companheirismo, confiança, diálogo, diplomacia, educação, empatia, flexibilidade, humildade, paciência, positivismo, respeito aos ritmos individuais, respeito às contribuições dos colegas, respeito às diferenças individuais, respeito às dificuldades do outro, respeito às opiniões do outro, respeito mútuo, saber ouvir, socialização, tolerância, valorizar o conhecimento do colega; 


\section{Estratégias metodológicas}

- Motivação;

- Atividades de grupo: colaboração e cooperação;

- Articulação entre objetivos propostos, conteúdos estudados e metodologia adotada;

- Contextualização teoria com a prática;

- Descentralização: rompimento das estruturas de poder entre professor e aluno;

- Avaliação: do curso, do grupo, auto-avaliação.

\section{Gestão}

- Estrutura tecnológica;

- Planejamento;

- Organização;

- Direção;

- Controle;

- Acompanhamento e análise permanente do processo.

Quadro 5: Fatores inerentes às dinâmicas colaborativas online Fonte: BARBOSA, tese, 2008, p. 241

Como na pesquisa de Barbosa, a análise dos dados que coletamos demonstra que a colaboração em comunidade virtual de aprendizagem consiste em um "processo complexo de atividades sociolingüísticas. Esse processo envolve a inter-relação de aspectos cognitivoafetivos individuais e construção de conhecimento, onde ocorre identificação pessoal por meio da interação com outras pessoas" (BARBOSA, 2008, p. 6).

Analisamos a colaboração em uma comunidade de aprendizagem como resultado de uma série de posturas individuais diretamente influenciadas pela interação com o grupo. Focamos as observações nos participantes do curso, mas contemplando o processo interativo no qual ele está inserido. Não podemos ignorar que as posturas adotadas seriam influenciadas pelo comportamento dos demais, afinal, trata-se de um processo sociolingüístico.

Pretendemos exemplificar, e explicar, o que entendemos como indicadores de formação de uma comunidade virtual por meio de mensagens de fóruns de discussão do curso "EAV 1". Escolhemos os fóruns porque, embora a participação naquele espaço era uma das atividades do curso, os alunos atuariam de forma mais livre do que no cumprimento dos desafios grupais, deixando aflorar a subjetividade e a transparecer de forma mais natural os indicadores de que tratamos.

Seria muito importante ressaltar que não desejamos apresentar indicadores estanques. Uma mensagem que revelaria reciprocidade também poderia indicar colaboração, já que tentamos tecer reflexões a partir do pensamento complexo, que "integra o mais possível os modos simplificadores de pensar, mas recusa as conseqüências mutiladoras, redutoras, unidimensionais e finalmente ofuscantes de uma simplificação que se considera reflexo do 
que há de real na realidade" (MORIN, 2006, p.6). Assim, um indício não exclui o outro, podendo ser uma complementação.

Ao apresentar os indicadores, separadamente, pretendemos lançar luz sobre os processos interativos que se desenrolam em uma comunidade no ciberespaço. Morin (2006) considera que qualquer conhecimento opera por seleção de dados significativos e rejeição dos não significativos, a exemplo de Moreno et al. (1999), para quem a atividade cognitiva seria realizada pelo sujeito a partir dos elementos da realidade aos quais ele confere significado e dos que desconsidera.

Segundo Morin (2006), uma pessoa separa (distingue ou disjunta) e une (associa e identifica); hierarquiza (o principal, o secundário) e centraliza (em função de noções-chave) os dados. Assim, apresentamos a seguir o mapeamento fruto do que construímos neste processo. Como esta reflexão se ampara em um curso online, nossos comentários fazem referência à comunidade virtual de aprendizagem "EAV1".

A exposição dos indicadores a seguir é fruto da análise das mensagens trocadas entre os participantes do curso e que expressariam o sentimento de comunidade e a colaboração entre os membros.

\section{Reciprocidade permanente}

A reciprocidade permanente seria um dos principais indícios de formação de uma comunidade virtual. Nesta análise, que contempla uma situação de aprendizagem, a reciprocidade é entendida como correspondência mútua entre os membros de uma rede. Como as relações sustentam e dão forma às redes sociais, sem reciprocidade não há rede de aprendizagem ou de qualquer outro tipo.

No entanto, em rede, a correspondência mútua mostra-se fluída, aberta, descompromissada. Já em comunidade, a reciprocidade seria mais intensa, constante e com o compromisso de dar um retorno às ações dos demais integrantes. O silêncio virtual seria mais encontrado nas redes de aprendizagem, não nas comunidades, onde a interação seria freqüente.

Na comunidade "EAV1", a maioria das mensagens dos fóruns, para não dizer todas, sempre possuía comentário/resposta dos participantes. Da mesma forma, as tarefas do curso também recebiam comentários dos colegas a respeito do trabalho desenvolvido. Esses 
comentários podiam acrescentar à aprendizagem ou não, mas certamente proporcionavam estímulo ao trabalho e às relações sociais.

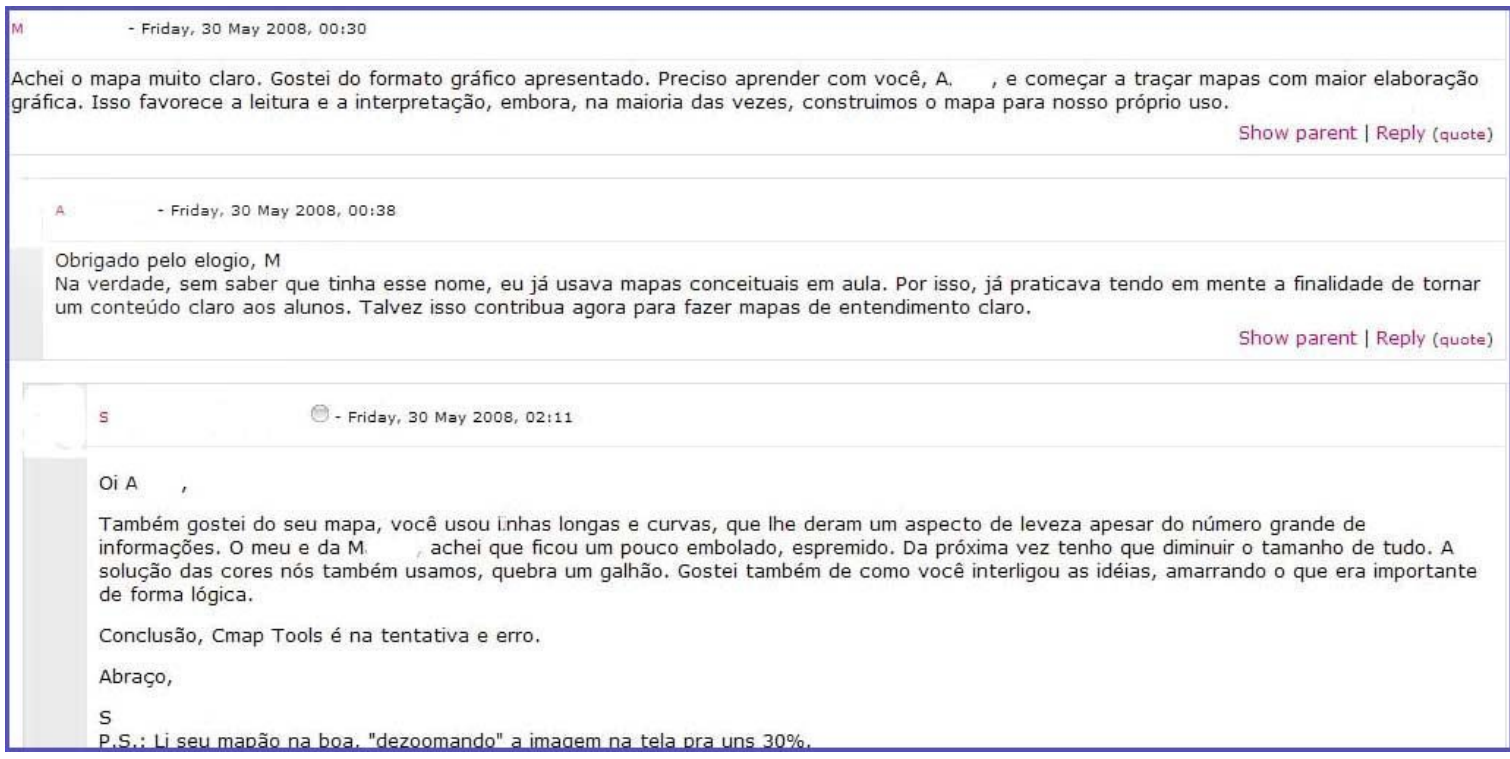

\section{Oi}

Também gostei do seu mapa. Qual o programa que vc usou para fazê-lo?

Bjs

\section{A - Sunday, 1 June 2008, 15:17}

Olá

Eu usei o cmaps.

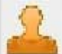

Monday, 2 June 2008, 04:04

só hoje consegui ver seu mapa, que ficou muito bonito! realmente, além de esteticamente agradével, dá uma noção de fluxo contínuo à proposta impressionate

parabéns! até eu q não sou muito pela temática indígena (ou indigenista, não sei o certo) faria seu curso só pelo mapa!

abs

Além das mensagens acima, a correspondência mútua pode ser conferida na interação a seguir. Após uma mensagem inicial, participantes solicitam informações adicionais ao que havia sido postado, como demonstra as duas primeiras reproduções. Diante do interesse demonstrado à sua contribuição, o autor da mensagem disparadora contribui com as informações requeridas $\left(3^{\mathrm{a}}\right.$. mensagem $)$. 
OiW

eu não li a Galáxia da Internet e essa informação sua é muito importante pra mim. Vc poderia dar-nos mais detalhe? Castells não fala em CVs? Eu tenho o entendimento de que dentro da "Sociedade em Rede" estão as CVs. Se vc puder dar mais detalhes eu agradeço bjs

Mensagem

Olá W

Também me interessei e gostaria de mais detalhes sobre o tema.

Abraços P

\section{Mensagem}

Há um capitulo no livro A Galáxia da Internet de Castells que se chama: "Comunidades Virtuais ou Sociedade de Rede?" Vejam que o título do capítulo em forma de pergunta já é bastante sugestivo

Ele começa dizendo que o crescimento do uso da internet e o surgimento das primeiras comunidades virtuais trouxeram à baila discussões bastante conflitantes que preconizavam o receio de que o homem abandonasse o convivio face a face por conta do proliferação do convivio virtual, levando o homem ao isolamento. $\mathrm{O}$ tempo foi passando $\mathrm{e}$ esses receios foram se mostrando infundados, já que o que se percebe é justamente o contrário: pessoas que se conectam virtualmente com frequêência têm maior possibilidade de contato com novos conceitos, novos mundos, novas pessoas, levando-as a querer sair mais para viver novas experiências.

Segundo ele, é certo que a internet vem reforçando a tendência ao individualismo que já vinha crescendo no mundo, mas que isto não significa tendência ao isolamento, mas sim valorização das diferenças e das idiossincrasias.

O capitulo termina com a seguinte frase: "Essas tendências [de reconstrução de estruturas de sociabilidade de baixo para cima] equivalem ao triunfo do individuo, embora os custos para a sociedade ainda sejam obscuros. A menos que consideremos que individuos estão de fato reconstruindo o padrão de interação social, com a ajuda de novos

recursos tecnológicos, para criar uma nova forma de sociedade: a sociedade em rede."

A reciprocidade permanente também pode ser entendida como acolhimento entre as pessoas. Em uma comunidade, os membros demonstrariam consideração às idéias dos colegas, acolhendo as opiniões - mesmo contrárias -, as perspectivas diferentes, as propostas, as iniciativas dos demais. Acolhimento não significa concordar com o ponto de vista do outro, mas considerá-lo e respeitá-lo durante as discussões.

Na mensagem abaixo, por exemplo, um participante responde à iniciativa de uma colega em contribuir com ele para liderar o grupo, posição de destaque entre os demais. A resposta revelaria uma atitude acolhedora:

\section{Mensagem \\ $\mathrm{Oi}$ \\ vou adorar sua companhia na liderança. Caso seja para vc fazer isso seja bem-vinda}

A reciprocidade como acolhimento seria demonstrada por atitudes generosas, pela disposição para o diálogo e para a negociação, sem que isto custe a anulação de quem acolhe. Incluiria receber um "não" como resposta a uma solicitação, assim como a decisão do colega de sair do grupo para fazer seu projeto sozinho, como mostra a próxima figura. 


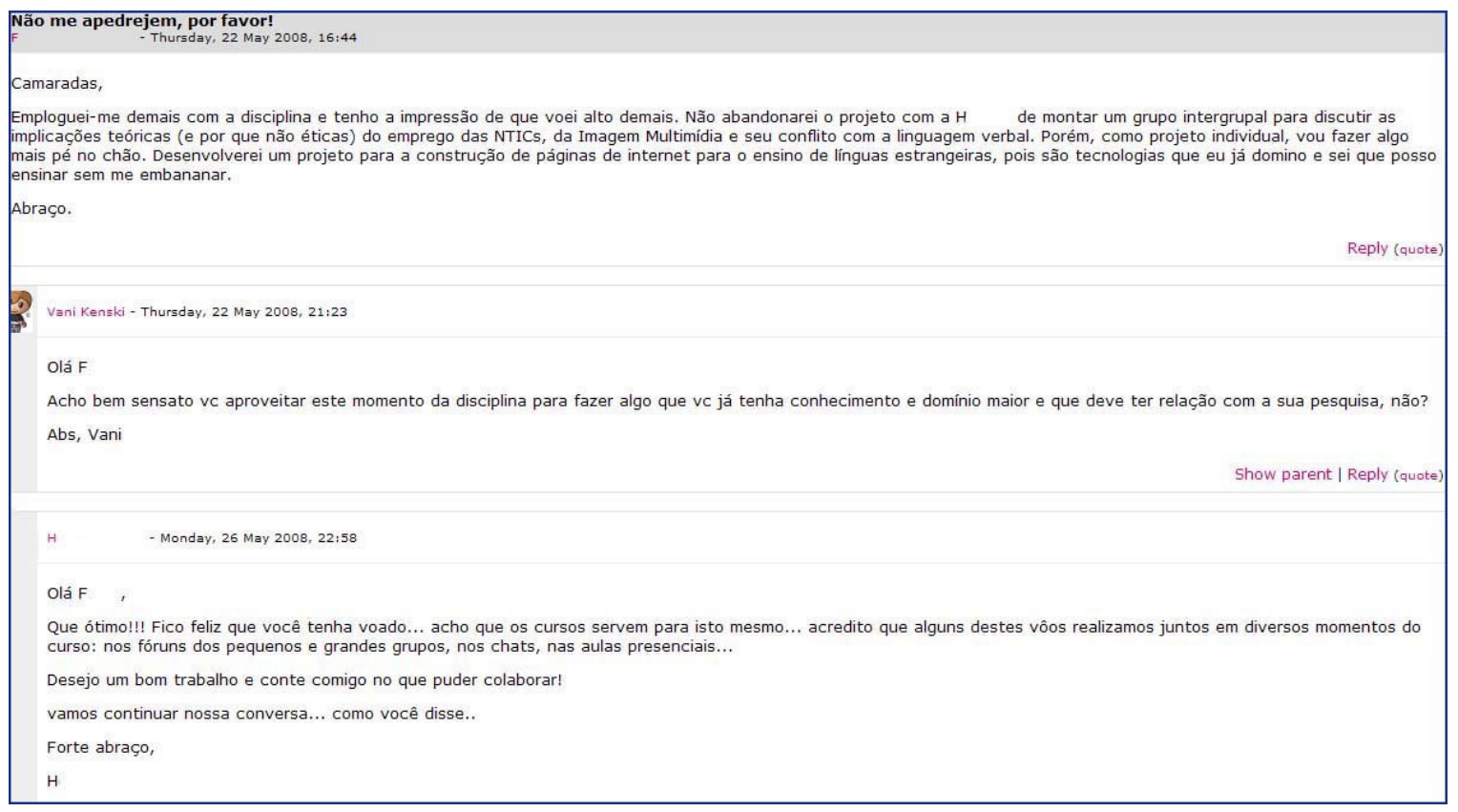

Processo complexo e altamente educativo, a reciprocidade é a base para que os laços entre os participantes se estreitem e eles possam constituir uma comunidade. Também é de fundamental importância durante o processo de aprendizagem, presente em diversas abordagens interacionistas e cognitivistas.

Piaget (1973), por exemplo, confere destaque à reciprocidade em sua obra. O autor definiu diversos graus de socialização do ser humano, acreditando que a inteligência se desenvolve em função das interações sociais. O grau máximo advém com o desenvolvimento da personalidade, que corresponde à submissão voluntária às normas de reciprocidade, e surge no estágio operatório, onde começam as trocas intelectuais. A reciprocidade, e, portanto, a personalidade, "é o produto mais refinado da socialização", diz Piaget:

A personalidade não é o "eu" enquanto diferente dos outros "eus" e refratário à socialização, mas é o indivíduo se submetendo voluntariamente às normas de reciprocidade e de universalidade. Como tal, longe de estar à margem da sociedade, a personalidade constitui o produto mais refinado da socialização. Com efeito, é na medida em que o 'eu' renuncia a si mesmo para inserir seu ponto de vista próprio entre os outros e se curvar assim às regras da reciprocidade que indivíduo torna-se personalidade [...]. Em oposição ao egocentrismo inicial, o que consiste em tomar o ponto de vista próprio como absoluto, por falta de poder perceber seu caráter particular, a personalidade consiste em tomar consciência desta relatividade da perspectiva individual e a colocá-la em relação com o conjunto das outras perspectivas possíveis: a personalidade é, pois, uma coordenação da individualidade com o universal. (PIAGET, 1977, apud LA TAILLE, 1992, p. 16, grifo nosso.)

Mas, para Piaget, nem todas as relações sociais contribuem com o desenvolvimento da inteligência. Ele distingue dois tipos: coação e cooperação. 
A coação é a relação entre pessoas no qual há elemento de autoridade ou de prestígio. Nela, o "indivíduo coagido tem pouca participação racional na produção, conservação ou divulgação das idéias" (LA TAILLE, 1992, p. 19), o que resulta em nível baixo de socialização. A coação leva ao empobrecimento da reciprocidade, uma vez que tanto o coagido quanto quem coagiu se isolam em seus respectivos pontos de vista, constituindo um freio ao desenvolvimento da inteligência.

Já na cooperação, segundo Piaget, há discussão, troca de idéias e todos controlam argumentos e provas, uma vez que a relação é simétrica. Quando não há assimetria, repetição, crença e imposição, o desenvolvimento acontece. A cooperação consiste no mais alto nível de socialização.

É a procura da reciprocidade entre os pontos de vista individuais que permite à inteligência construir este instrumento lógico que comanda os outros, e que é a lógica das relações. (PIAGET apud LA TAILLE, 1992, p. 19).

A cooperação, portanto, é condição necessária para o desenvolvimento da inteligência, construção da personalidade e amadurecimento das relações. É esse tipo de reciprocidade que encontramos nas redes e nas comunidades virtuais de aprendizagem.

Nelas, conforme vimos tratando, a presença do professor existe para estimular a cooperação e não para exercer coação. Embora ele se encontre, em alguns momentos, vale ressaltar, em assimetria com os demais, não poderia existir uma relação de coação, como explicitado por Piaget nas relações aluno-professor. Sua função é a de despertar e estimular a cooperação entre todos para novas descobertas, reflexões e construção de conhecimento.

\section{Compromisso implícito}

Outro indício de formação de uma comunidade seria o compromisso implícito desenvolvido entre os membros. Intimamente ligado à reciprocidade, o compromisso diz respeito ao comprometimento que os pares assumem, tacitamente, em se corresponder com o outro, em responder às necessidades, ajudar os colegas, em não deixá-los “abandonados” em ambiente virtual.

O compromisso resultaria do estreitamento de laços entre os participantes e da reciprocidade intensa entre os pares. Contrapondo-se à rede, no qual as relações são mais 
fluidas e não existira essa "obrigatoriedade", a correspondência mútua na comunidade mostrar-se-ia mais "amarrada".

Em situação de aprendizagem, o integrante de uma comunidade teria consciência da importância de sua participação no processo e crescimento do grupo, comprometendo-se em contribuir para a construção de conhecimento de todos.

As mensagens a seguir exemplificariam esse indicador porque mostram a preocupação em cumprir os combinados:

Mensagem

Já inseri no meu porttólio o quadro sobre a Teoria de Aprendizagem Significativa de Ausubel.

Sempre procuro deixar tudo em ordem até o domingo porque a segunda-feira para mim é um dia atribuladíssimo, com monitoria de turmas na FEUSP até 23 horas. Então mal consigo checar meus e-mails nas segundas-feiras!

De qualquer forma, caso vocês queiram sugerir alguma alteração para a minha atividade individual postada, por favor, enviem, que estarei atenta às mensagens na medida do possivel

$R$. . obrigada pelas informações sobre o texto disponivel para leitura!

abçs

OiNós,

Estou terminando as atividades e amanhã de manhã pretendo colocar no ambiente

S. mandei para você via e-mail do resumão da teroria Aprendizagem baseada em problema. Fique à vontade para sugerir algo

Só lembrando, a amanhã é o prazo máximo que temos para postarmos a atividade individual.

Bis a todos e bom trabalho

\section{Olá colegas do grupo Equilibrium.}

Desculpem-me a ausência repentina... Acumulei muitas tarefas para a mesma semana e acabei participando pouco das discussões aqui.

Acabo de postar minha atividade individual sobre a Teoria da Atividade

Vou agora descobrir como colaborar com a atividade grupal.

Até mais grupo!

Abraço,

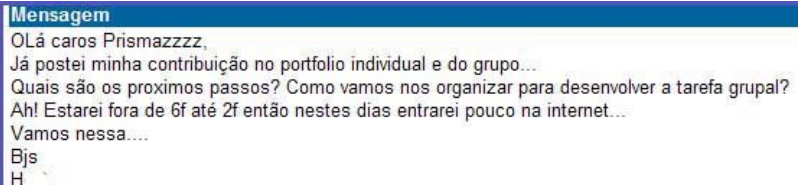

\section{Iniciativa}

O compromisso implícito e a reciprocidade permanente, mapeados como indícios de formação de comunidade, obviamente dependem da iniciativa e da disposição de cada pessoa. No entanto, algumas participações parecem expor o objetivo explícito de contribuir com a aprendizagem dos demais e para o processo desencadeado em comunidade, sem que tais contribuições tenham sido solicitadas.

Como exemplo, nas mensagens a seguir, dois participantes resumiram as reflexões apresentadas até aquele momento da discussão no Fórum para, então, apresentarem as suas. A 
iniciativa contribui para dar a todos um panorama do debate, sem que o resumo tenha sido uma solicitação do professor ou dos pares.

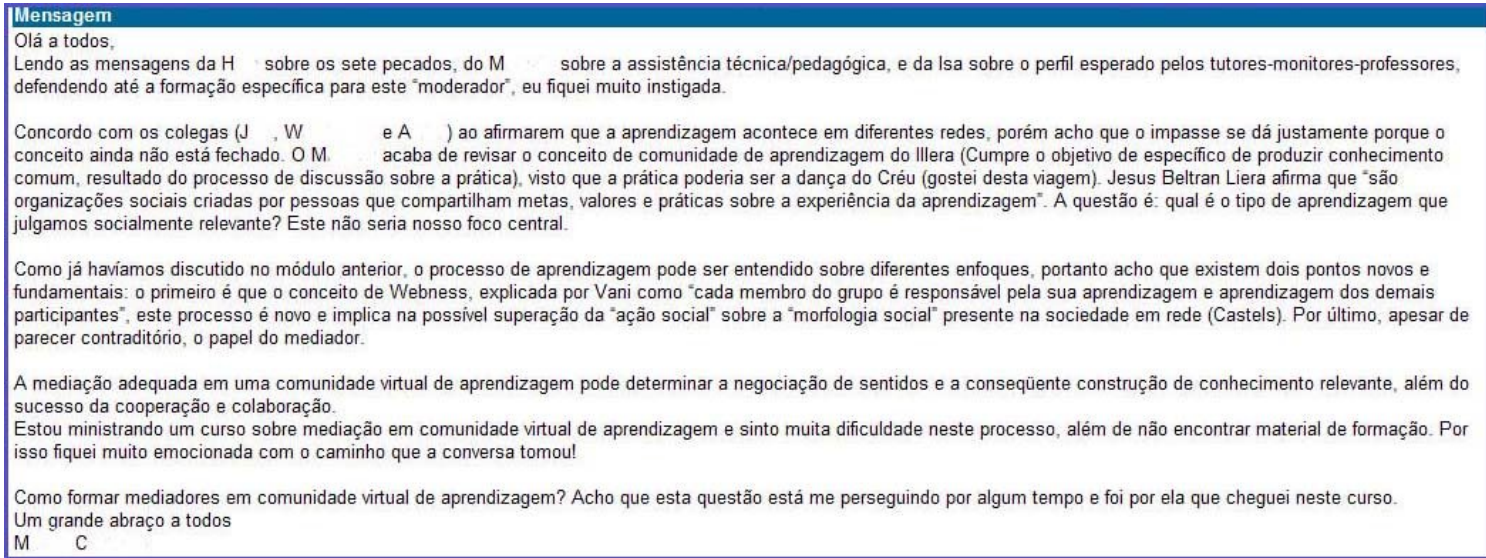

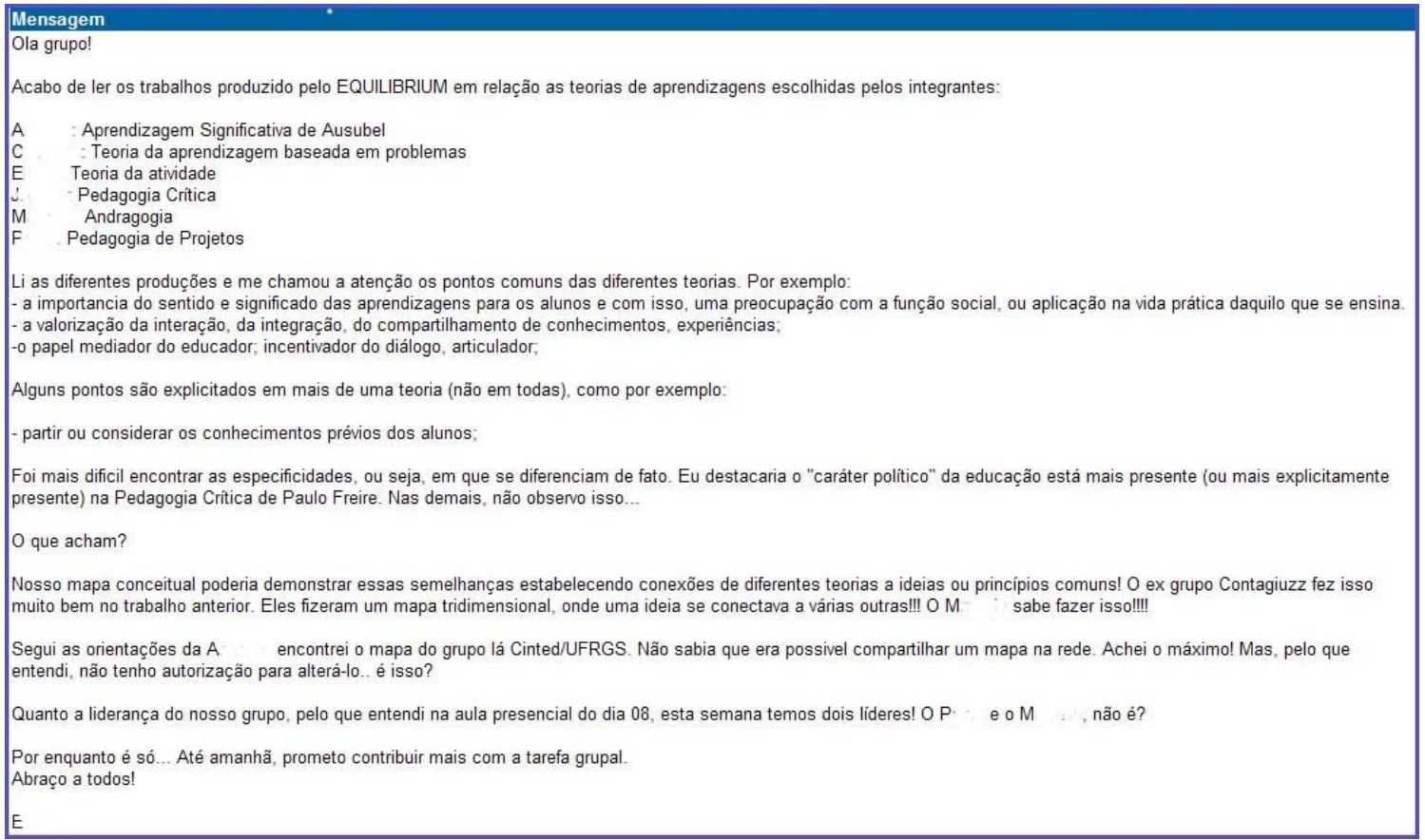

Outro exemplo de iniciativa espontânea seria a mensagem a seguir, na qual um participante se oferece para compartilhar a liderança do grupo. Seu objetivo seria evitar que o líder da semana ficasse sobrecarregado. 
$\mathrm{Na}$ mensagem abaixo, o aluno sugere outro programa para que os participantes façam os trabalhos, que considera mais simples (Intelimap), apesar da professora do curso ter indicado um software específico (CmapTools) para a atividade.

Eu também vou viajar na sexta de manhã e só volto na segunda e não terei como acessar a internet. Por isso, me prontifico a iniciar o mapa com as sinteses que já temos

disponiveis e na segunda volto a entrar. Vocês conhecem o intelimap? Ele parece um arco-rís e até combina com o nome do nosso grupo. Posso mandar o software para vocês experimentarem. É muito simples, mais fácil de usar que o cmap-tools

Ao apresentar um software como alternativa, resumir o que havia sido discutido anteriormente e oferecer-se para dividir a liderança, esses participantes teriam contribuindo com a aprendizagem de seus colegas e com a própria. No primeiro caso, os pares passaram a conhecer um novo recurso tecnológico; no segundo, os participantes sintetizaram os conceitos para elaborar seus conhecimentos e contribuir com a reflexão dos demais; e, quanto à liderança, a aprendizagem seria a de exercitar um papel social cada vez mais requisitado.

\section{Informalidade}

Outra postura que poderíamos identificar entre os membros de uma comunidade seria a informalidade, que acaba por revelar o grau de proximidade entre os pares. Afinal, entre "amigos" podemos discutir assuntos importantes de forma mais solta, coloquial. A informalidade contribui para expressar que fazemos parte de uma comunidade e nos sentimos à vontade para expor o que pensamos. Essa expressão é parte importante de um processo de aprendizagem, já que confrontando as diversas opiniões pode-se reelaborar conceitos e constituir novos paradigmas.

A sequiência de mensagens a seguir apresenta uma linguagem informal e revelaria certa intimidade entre os participantes. Na última delas, os emoticons são usados pelos alunos para manifestarem seus sentimentos, uma vez que na maioria dos ambientes online utilizado para cursos as atividades são assíncronas e, assim, eles não podem ver a expressão do rosto 
e/ou o tom de voz dos colegas na interação - poderiam se estivessem participando de uma atividade síncrona, por exemplo, uma webvideoconferência. A emoção, e mesmo os próprios participantes, acabam sendo representados por textos e sinais na tela dos ambientes virtuais, os emoticons.

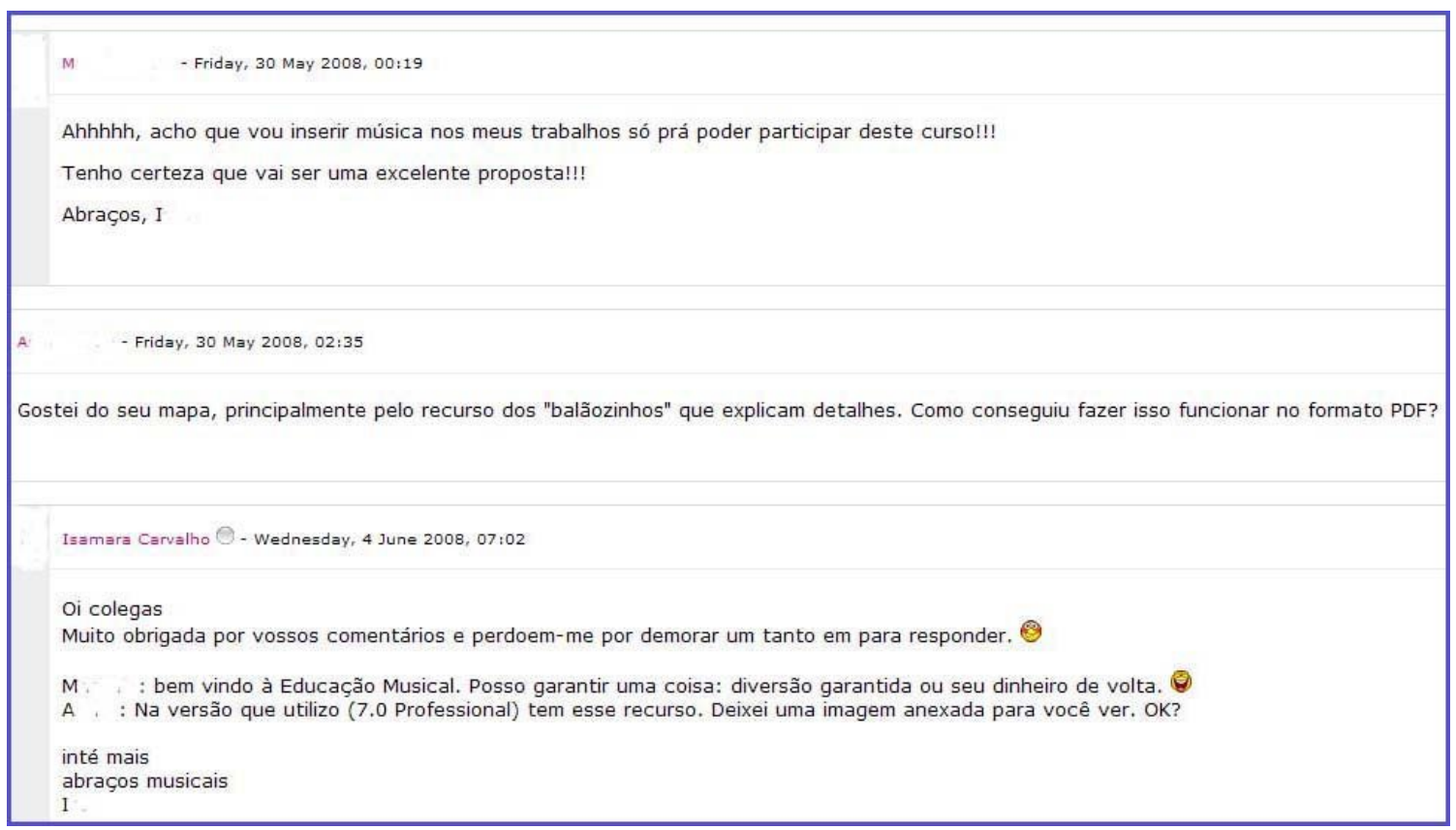

Alguns autores ressaltam a importância dos elementos não-verbais, como os emoticons, para aproximar os participantes de uma comunidade e ajudar na compreensão do significado de uma mensagem publicada em ambiente virtual:

[a] presença e a interacção face a face inclui uma boa dose de elementos não-verbais que contribuem para situar o significado de uma mensagem, e, de facto, considera-se que a interpretação do canal não verbal está associada à veracidade da mensagem. Isto é, na comunicação mediada por computador (CMC) perde-se, em parte ou totalmente, conforme o tipo de $\mathrm{CMC}$, um canal muito importante de comunicação, o que no caso das comunidades virtuais conduziu a que, até ao presente, se venham baseando quase exclusivamente na escrita. (RODRÍGUEZ ILLERA, 2007, p. 118).

Outro exemplo demonstraria a descontração de um participante que salvou o trabalho em um formato que não poderia ser aberto pelos demais. Depois, também em tom de informalidade, um colega critica o mapa dizendo que parece com os que produz: 


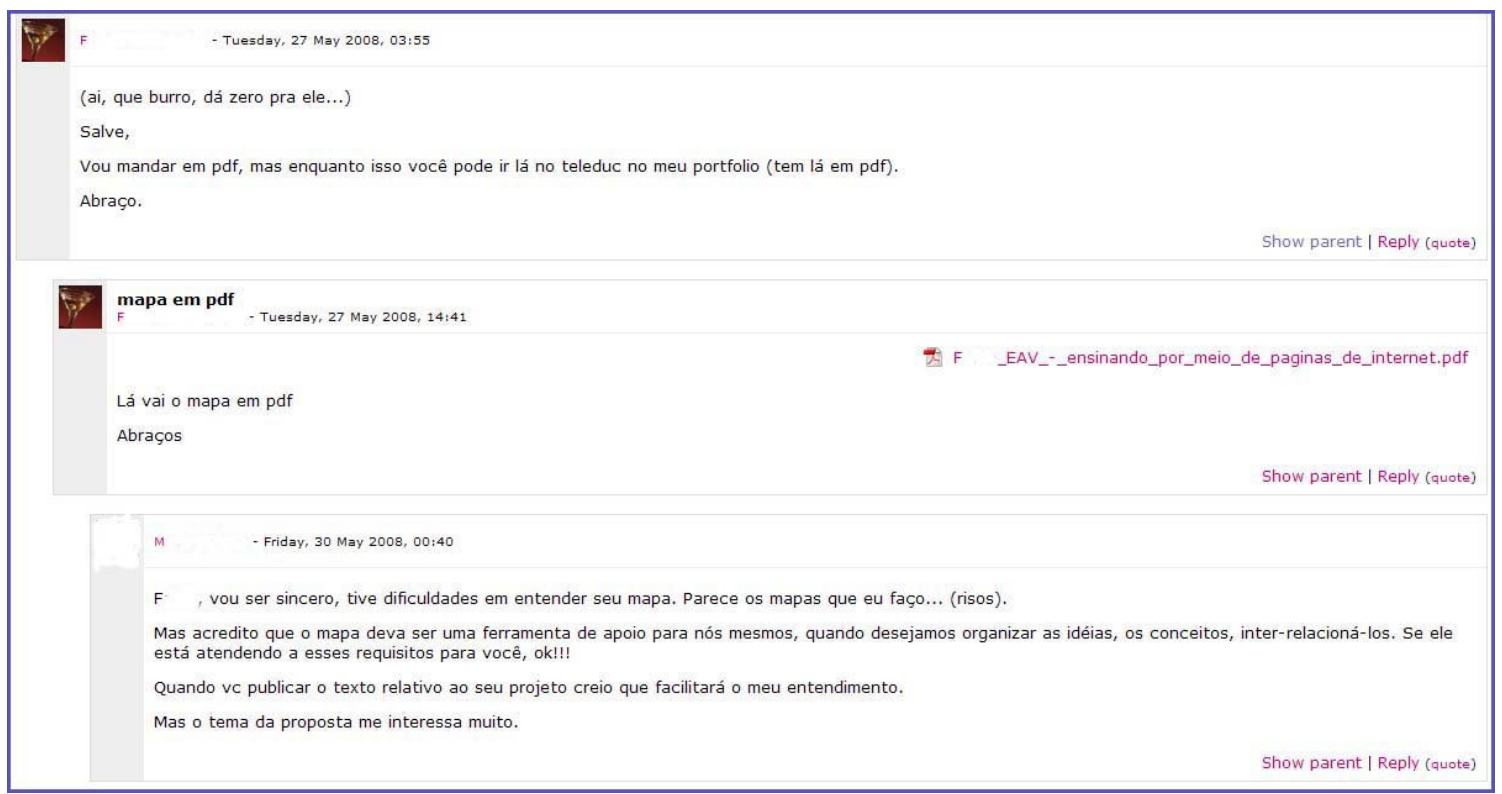

Acreditamos que a informalidade não prejudica a aprendizagem. Ao contrário, ao promover a aproximação entre os alunos, a linguagem informal aumenta a interação e torna-se parte importante do processo. "É por meio dos relacionamentos e da interação que o conhecimento é fundamentalmente produzido na sala de aula online" (PALOFF; PRATT, 2002, p. 38).

\section{Colaboração}

Reciprocidade permanente, compromisso implícito, iniciativa e informalidade seriam indícios de formação de uma comunidade e, na situação de aprendizagem em questão, do alto grau de envolvimento entre os participantes e no processo educativo para o qual se reúnem. Como em uma rede, são nós que não apenas se ligam, mas se reforçam, e contribuem para o surgimento de outro nó: a colaboração.

No capítulo 1, vimos, por meio de Recuero (2005) que, em uma comunidade virtual, a maioria das relações precisa ser cooperativa, pois ela sedimenta as relações sociais, criando uma estrutura. "Quanto mais interações cooperativas, mais forte se torna o laço social desta estrutura, podendo gerar um grupo coeso e organizado".

Nesta dissertação, adotamos a abordagem colaborativa, em vez de cooperativa, porque entendemos que a primeira diz respeito às atividades realizadas em conjunto, com o 
envolvimento das pessoas em todo o processo, possuindo uma dimensão filosófica mais ampla, embora estejamos de acordo a essência da frase de Recuero.

A metodologia do curso desenvolvida por Vani Kenski baseia-se em abordagens colaborativas e, portanto, grande parte da colaboração entre os participantes analisada deve-se às estratégias metodológicas. Mas acreditamos que a convivência intensa entre os alunos durante o "EAV 1", indicada pelo mapeamento exposto, revela comportamentos colaborativos para além do cumprimento das atividades.

Para detalhar a colaboração que encontramos, analisamos a interação no Fórum “Comunidades Virtuais de Aprendizagem", realizada no ambiente TelEduc, para debate a respeito da natureza dessas comunidades.

Após uma mensagem inicial, outras 54 postagens foram enviadas, sempre dialogando com alguma ou com todas as anteriores. De modo geral, as mensagens revelam a leitura das demais e contribuem com novas idéias e/ou posicionamento a respeito.

A primeira mensagem, da professora Vani Kenski, deu início ao debate:

\footnotetext{
Howard Rheingold, o autor mais antigo e mais citado quando se trata de "comunidades virtuais", disse certa vez que, para ele, "toda comunidade virtual é... de aprendizagem". Para pensar melhor no assunto, é preciso identificar o que Rheingold chama de aprendizagem e o que nós consideramos como aprendizagem. Será que estamos falando da mesma coisa?

Rheingold expande a idéia de Turoff (pesquisador americano, idealizador do sistema de intercâmbio

de informação eletrônica -EIES) de que "um grupo bem sucedido exibirá um grau de inteligência maior em relação a qualquer um de seus membros".

Talvez venha dessa articulação uma das bases para a criação da idéia de "inteligência coletiva" de Lévy que se realiza nas... comunidades virtuais.

Kerckhove tem uma palavra especifica para essas comunidades virtuais - webness - ou seja, uma comunidade de pessoas, conectadas via Internet, que aprendem e avançam juntas no conhecimento, preocupadas com a sua aprendizagem e com a aprendizagem de todo o grupo.

Vocês, que jả leram e refletiram sobre o tema nesta semana, o que acham? Concordam com Rheingold? Com Lévy? Com Kerckhove? Será que podemos mesmo generalizar e considerar que todas as comunidades virtuais, de alguma forma, são de aprendizagem?
}

Na mensagem abaixo, o participante revela ter lido a postagem inicial e a dos colegas (alguns são citados), refletido a respeito e, então, apresenta sua posição quanto à discussão que se realiza - uma iniciativa que colaboraria com a aprendizagem dos demais à medida que lança um olhar complementar. 
oi gente!

concordo com grande parte das colocaçôes porém:

1. acabo discordando da s qto à area da saúde: muito se fala em relação a isso e pouco se sabe, até pelos semi-deuses (pros não adaptados a esta linguagenm, estes são os médicos!), na verdade, o conhecimento está fugindo aos profissionais e emergindo das comunidades virtuais que se prontificam a aprender, principalmente baseadas em seus proprios problemas médicos, que não são solucionados pelos profissionais que deveriam fazê-lo, obrigando-nos a procurar respostas. o problema é que nem toda resposta é correta (sabemos disso, somos professores!). nesse sentido, nossa funçâo é direcionar e orientar e não podar a busca, como vejo em muitas situaçôes, mas não creio q a academia seja a única capaz de produzir as respostas corretas, o problema é que estamos completamente viciados em buscar o "saber real e absoluto" nas academias. vejamos nossa comunidade EAV1: será que ela se constituiria tão proficua fora da chancela da academia?

2. concordo com o $\mathrm{m}$ : aprendemos a todo momento, sozinhos e acompanhados, porém não aprendemos todo o tempo o conhecimento acadêmico, institucionalizado que se convencionou chamar conhecimento. aprendemos padrões morais, sociais, comportamentais, etc. creio que o mais importante não é o que se aprende e sim o que se faz com o que se aprende.

o aprendizado por si só é vago e vazio se não puder ser questionado, aplicado e discutido.

3. por uma questão de coerência, concordo plenamente com lévy: todo saber está nas comunidades (virtuais ou não, ele mesmo chega a propor que estabeleçamos comunidades de aprendizado não virtuais se essa fora única opção, se bem que isso é umaproposta de uma época passada!). é impossivel apreender todo o saber em uma única pessoa a'te por que qdo um indivíduo julga já saber tudo sobre algo surgem novas propostas sobre 0 assunto, fazendo com que os saberes sofram um ciclo de obsolescência constante. 3. sem me alongar mais do que já fiz, volto a concordar com o marcelo: é necessário observar e, principalmente, integrar as comunidades virtuais de forma a fazer proliferar idéias e saberes interessantes e produtivos para além dos meros casualismos e padrões de conduta por vezes questionáveis que observamos em muitas das comunidades de relacionamento.

é necessário não esquecer que conhecimento é tudo e não só o academicismo.

bjs

Para contribuir com o debate, outra participante apresenta à comunidade o que dizem alguns autores a respeito de pontos que são discutidos. Um entendimento sobre a natureza da aprendizagem, a necessidade de planejamento em CVAs e um exemplo de curso online são informações que enriquecem o diálogo, colaborando com o conhecimento dos demais.

Bom dia, Colegas:

O filósofo Hugo Assmann em seu livro "Reencantar a Educação" (2000) (esta obra merece ser lida, gentel) afirma que viver é aprender. Todo ser vivo aprende o tempo todo. Ele relaciona aprender com adaptar-se. Aprender é, portanto, involuntário. Este conceito de Assmann me parece muito próximo daquele apresentado por Howard Rheingold, que afirm que aprendemos o tempo todo.

No entanto, acho que aqui estamos falando, como já comentaram M el de uma aprendizagem especifica, ligada ao desejo de aprender devido a determinados

objetivos.

Em seu livro "Comunidades Virtuais" (1993), Howard Rheingold inclusive deixa claro que sua obra não tem intenção de tratar de Educação

Portanto, quando falamos de Comunidades Virtuais de Aprendizagem, há planejamento, metodologia e objetivos definidos.

Há CVAs nas quais os participantes podem ter liberdade para concluir as etapas da maneira que quiser e no prazo que quiser, no entanto o programa está lá estabelecido. Um bom exemplo de comunidade virtual de aprendizagem em moldes contemporâneos é o curso oferecido pela Editora Pearson e pelo Prof. João Mattar no Second Life, cujas inscrições encerram-se dia 09/05(http://admail.pearson.com. br/SL2/sl2page.htm). O curso é aberto a todos, no entanto, aquele que quiser fazer sua inscrição por R\$ 45.00 , receberá em casa um exemplar do livro ABC da EAD do Prof. João Mattar e um certificado de participação no evento. Ou seja, você não precisa pagar para aprender num curso como este! Nem mesmo precisa ser frequentador assiduol

Otto Peters em seu livro Educação a "Distância em Transição" (2003) ressalta que num futuro não muito distante toda a educação de adultos assumirá moldes semelhantes ao exemplo do curso da Editora Pearson descrito acima

A Open University de Londres já faz isto.

abçs

Como no caso acima, das 55 mensagens do fórum "Comunidades Virtuais de Aprendizagem", 11 apresentam informações de autores. Mais do que enxergarmos nessa observação a marca da colaboração, essas mensagens revelariam o desejo de compartilhar com a comunidade o que se aprendeu individualmente.

Apresentar um resumo de textos lidos, muitas vezes fora da bibliografia do curso, revelaria o sentimento de pertencimento à comunidade, o compromisso com a aprendizagem do outro e, portanto, um exemplo de colaboração para a construção de conhecimento de todos os participantes.

O que se aprende é compartilhado, contra uma posição individualista na qual o que os alunos lêem ficaria apenas para si, para serem usados - no caso do perfil dos alunos da 
"EAV1" -, em suas produções acadêmicas. Outras duas mensagens também ilustrariam esse entendimento. A segunda parece ter-se inspirado na iniciativa da primeiro, enviada antes.

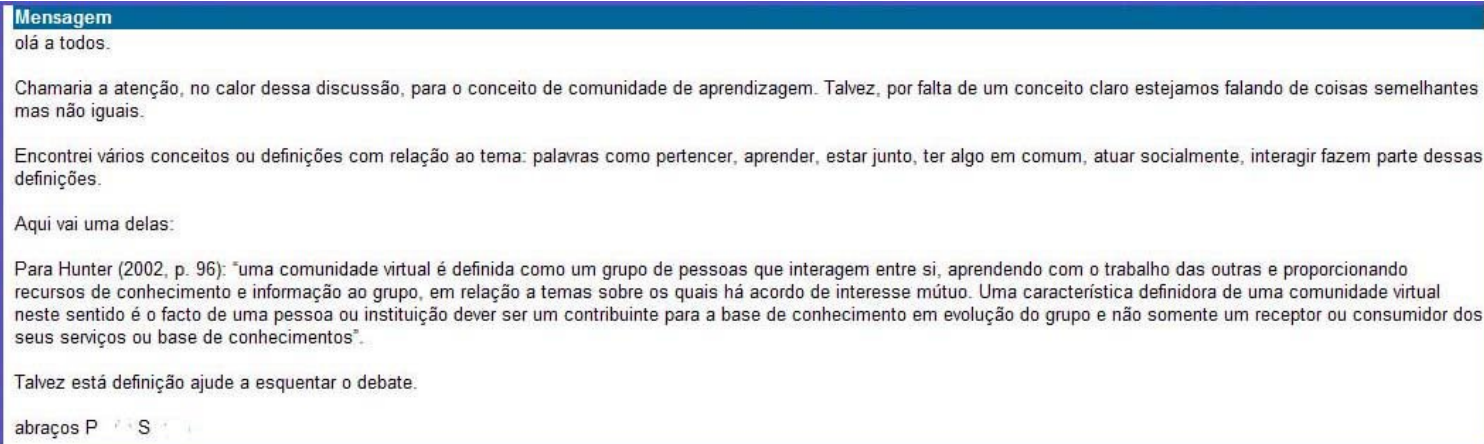

Para Hunter (2002, p. 96): "uma comunidade virtual é definida como um grupo de pessoas que interagem entre si, aprendendo com o trabalho das outras e proporcionando recursos de conhecimento e informação ao grupo, em relação a temas sobre os quais há acordo de interesse mútuo. Uma característica definidora de uma comunidade virtual neste sentido é o facto de uma pessoa ou instituição dever ser um contribuinte para a base de conhecimento em evolução do grupo e não somente um receptor ou consumidor dos seus serviços ou base de conhecimentos".

Talvez está definição ajude a esquentar o debate.

abraços $P$ S

menensagem

OP nos traz um conceito de comunidade de aprendizagem para facilitar as nossas discussões.

Com o mesmo objetivo, vou trazer alguns conceitos que podem nos ajudar a entender a diferença entre a comunidade de aprendizagem e a comunidade prática, que por sua vez pode nos ajudar a visualizar que qualquer comunidade pode ser de aprendizado e que de acordo com os nossos interesses nos aderimos a uma e a diferença entre as comunidades de aprendizagem e de prática, proposto par alguns autores.

Segundo Illera (2007), a teorização sobre as comunidades de prática pressupõe também uma mudança importante nas concepções de aprendizagem. Assim como as comunidades virtuais de aprendizagem se baseiam em teorias novas de aprendizagem, as comunidades de prática mudam o enfoque do que se entende por aprendizagem. Não se trata de considerar que uma abordagem é mais importante do que a outra, mas de entender as suas diferenças e procurar situar a noção de aprendizagem num contexto mais geral: o da instituição educativa e o da própria vida das pessoas que aprendem. Por isso acho que vivemos aprendendo como disse o Marcelo, escolhemos as comunidades de acordo com o que queremos aprender, como por exemplo o Orkut citado pela C e esse aprendizado não necessariamente tem de ser institucionalizado ou vindo da academia, como enfatizou a $\mathrm{P}$

Continuando, Illera, afirma que nas comunidades de prática não é apenas a aprendizagem, muito menos uma abordagem didática que a contempla como um mero output de eficácia dos processos de ensino, mas a relação entre a aprendizagem e o conjunto da vida pessoal e social. Quando se refere às comunidades como origem da vida social, a aprendizagem não é vista como um fim em si mesmo, mas como uma componente mais do conjunto da experiência

Riel e Polin citados por Illera (2007) distinguem três tipos de comunidade:

- Comunidades de aprendizagem orientadas para tarefas (um grupo de pessoas unidas com o fim de realizar uma tarefa e obter um produto):

- Comunidades orientadas para prática (um grupo amplo de pessoas que revela interesse em partilhar uma pratica em comum):

- Comunidades orientadas para a construção do conhecimento (semelhantes às anteriores, mas cumprem um objetivo especifico de produzir conhecimento como resultado de processo de discussão e prática.

Cada uma delas é pensada de acordo com uma série de dimensões: a pertença como membro da comunidade, características das tarefas ou dos objetivos de aprendizagem do grupo, estruturas de participação e mecanismos de crescimento e reprodução.

Hakkarainen et al apud Illera (2007) descreve no contexto das comunidades virtuais de aprendizagem, os diferentes tipos de modalidades adotados: o critério, ou seja, o tipo de participação e objetivos dos participantes. Assim distinguem comunidades em que os membros procuram a aquisiçâa de conhecimento, participam ativamente e, por fim, criam conhecimento novo conjuntamente com os outros participantes. Então temos que as comunidades construtoras de conhecimento como objetivo educativo em que a ênfase é dad à análise das comunidades virtuais em ambientes intencionalmente educativos, na perspectiva de criação de conhecimentos de modo colaborativo e reflexivo entre todos os participantes (enfoque de Scardamaglia, Bereiter apud Illera, 2007). Acho que nessas comunidades, podemos falar sobre a necessidade de uma assistência, do acompanhamento do planejamento, da metodologia, da definição de objetivos e, complementando, do apoio às teorias de aprendizagem como disseram W e M

Para mim fica nítido que aprendemos em todas as comunidades, mas existe uma diferença entre comunidades de aprendizagem e comunidades construtoras de conhecimento que tem como intuito a criação de conhecimentos de modo colaborativo e reflexivo entre todos os participantes em que o papel do tutor, formador assume grande importância para orientar o aprendizado do aluno.

$\mathrm{O}$ que vocês acham?

Bjs $\mathrm{K}$

Além de comentar a mensagem do colega e levar autores para a discussão, a colaboração neste fórum apresentar-se-ia por meio de indagações que levariam os participantes a refletir, como parte da reelaboração de conceitos. 


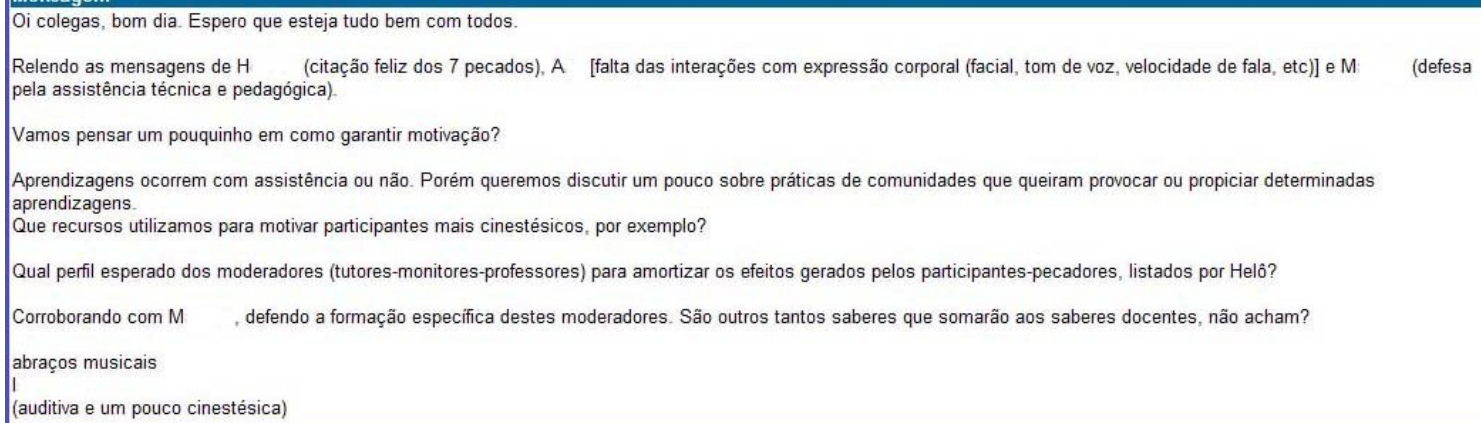

Nesse Fórum, os participantes concordaram que todas as comunidades virtuais poderiam proporcionar aprendizagens. Mas quanto à natureza e como se referir às de aprendizagem não houve consenso, o que não invalida o processo educativo, pelo contrário, estimularia a busca por mais respostas.

Gostaríamos de destacar outras duas últimas mensagens seqüenciais do fórum "Comunidades Virtuais de Aprendizagem":

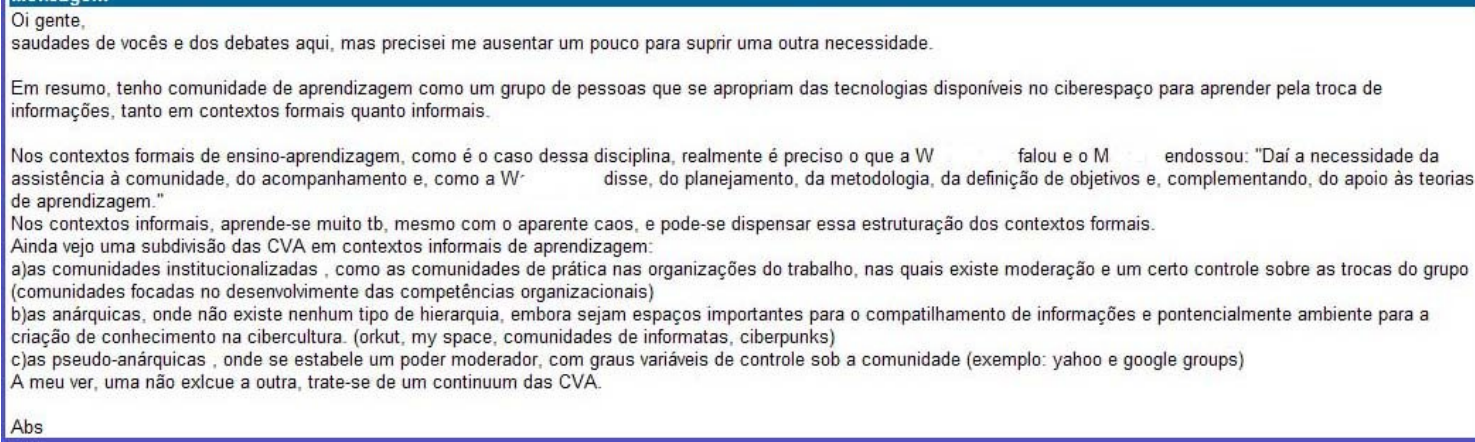

Dialogando com a reprodução anterior, o que os colegas chamam de "Comunidades Virtuais de Aprendizagem não Assistidas" são nomeadas nesta dissertação apenas de comunidades virtuais porque permitem aprendizagens a partir da perspectiva da Educação Informal, aquela que não contempla um planejamento prévio por parte de quem ensina e/ou de quem aprende, ocorrendo sem que se dê conta (SIMSON, PARK, FERNANDES, 2007).

Já o que os colegas nomeiam de "Comunidades Virtuais de Aprendizagem Assistidas", que, segundo eles, contemplariam "planejamento, metodologia e definição de objetivos", são tratadas nesta pesquisa como elementos distintivos das redes e comunidades virtuais de aprendizagem, onde acrescentamos a esses elementos apenas a presença do professor. 


\section{Intervenção pontual do professor}

As mensagens do fórum "Comunidades Virtuais de Aprendizagem" demonstrariam a colaboração entre os participantes. Mas, além desse e dos demais indicadores, acreditamos que um outro indício da formação de uma comunidade virtual, especificamente nas de aprendizagem, seja a intervenção pontual do professor.

Quando há, efetivamente, participação e colaboração, quando os "alunos" se responsabilizam por sua própria aprendizagem e a dos demais, quando possuem compromisso com a comunidade, o professor interviria no processo somente quando necessário.

Das 55 mensagens do fórum "Comunidades Virtuais de Aprendizagem”, apenas duas foram da professora do curso: a primeira, para dar início às discussões, e a 50ª acrescentando uma informação importante ao que estava sendo discutido.

Quando os alunos "têm maturidade e independência na construção de suas próprias aprendizagens", o professor "pode desenvolver um estilo de orientação supervisionada [...] com intervenções diretas mais esporádicas, incentivando as relações entre alunos e colocando desafios para que se superem a todo instante", explicou Kenski no fórum "Cursos Online e a Realidade dos Alunos" $" 41$.

Realizado no ambiente da CoLearn, colegas do curso "EAV 1" relatam no fórum a pouca participação dos estudantes em cursos a distância nos quais são tutores, fazendo-se necessárias suas presenças de forma constante. O comentário de Kenski e o relato dos colegas surgiram em meio a uma discussão sobre a dificuldade dos tutores acompanharem os alunos em classes numerosas. O debate surgiu após esta aluna-pesquisadora ter enviado uma mensagem sobre uma intervenção mais pontual do professor:

Jaciara Carvalho $\bigcirc$ - Saturday, 31 May 2008, 20:58

Oi, pessoal,

Pra colocar mais lenha na fogueira:

será que um bom caminho não seria criar estratégias para que a relaçao não fosse aluno-tutor, mas aluno-aluno e, então, de forma colaborativa, constituíssemos uma comunidade nestes cursos?

Percebam: a Vani está de olho, se manifesta quando necessário, mas aqui é a relaçao principal é aluno-aluno. Estou certa?

Gostaria de "ouvir" quem já é tutor pra saber se isso seria possivel (se há ferramentas que possibilitam a comunicaçao entre os alunos, etc).

obrigada!

bjs jaci

\footnotetext{
${ }^{41}$ Disponível em <http://labspace.open.ac.uk/mod/forum/discuss.php?d=529>. Acesso em 10 jun. 2008
} 
Kenski que, como escrevi na mensagem, "estava de olho", respondeu explicando que muitos grupos "precisam de uma participação mais direcionada [...] não se abrem para uma cultura da colaboração... precisam da atuação mais freqüente do professor/tutor e o desenvolvimento gradual de estratégias de conquista da autonomia no aprendizado pelos alunos”. Eis a íntegra da mensagem de Kenski:

Vani Kenski $\bigcirc$ - Sunday, 1 June 2008, 18:59

É Jaci

EStou sempre por aqui.

E é importante garantir o desenvolvimento das relações entre todos, principalmente entre os alunos, dentro dos princípios de uma formação para a autonomia, interação, cooperação e colaboração que deve existir em uma comunidade.

Como "falei" acima, vamos dar destaque à palavra "desenvolvimento". Em um grupo emn que as pessoas já tem maturidade e independência na construção de suas próprias aprendizagens - como o nosso EAV1 - você pode desenvolver um estilo de orientação supervisionada... o "to de olho" da Jaci, com intervenções diretas mais esporádicas, incentivando as relações entre alunos e colocando desafios para que se superem a todo instante.

Infelizmente, nem todos os grupos são assim. Muitos ainda precisam de uma participação mais direcionada, têm dificuldade para trocar idéias, informações e são muito introvertidos, não se abrem para uma cultura da colaboração... precisam da atuação mais freqüente do professor/tutor e o desenvolvimento gradual de estratégias de conquista da autonomia no aprendizado pelos alunos.

o processo educacional deve respeitar o momento do grupo e trazê-los gradualmente a essa autonomia na escolha dos seus caminhos de aprendizagem partilhada e colaboração, aí começamos a ter uma vivência em comunidade de aprendizagem.

Abraços, Vani

As próximas mensagens complementam a da professora e tratam da dificuldade de trabalhar com alunos da Graduação e com professores da rede pública em cursos a distância.

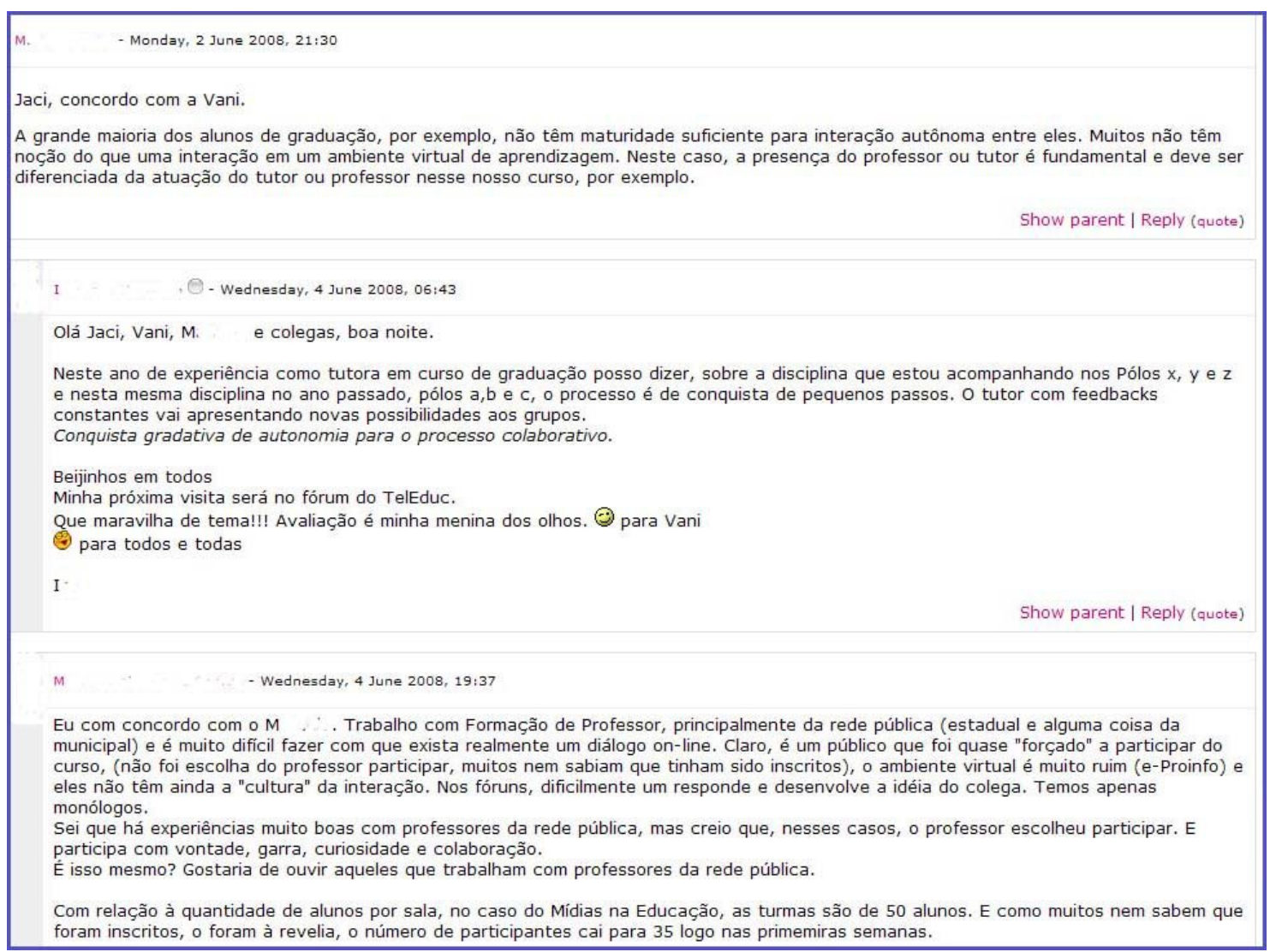


Como relatado pelos colegas, também percebemos durante esta pesquisa que, em algumas redes de aprendizagem online, a intervenção do professor é maior. Ele se faz mais presente para motivar os alunos, apresentar questionamentos, chamá-los ao debate - há casos em que responde cada mensagem enviada pelos participantes.

Esse cenário é atribuído nesta dissertação às redes de aprendizagem online. Já em uma comunidade virtual de aprendizagem, os laços mais estreitos entre os membros e o compromisso com a sua própria aprendizagem e a do outro permitiriam que o professor observe tudo, mas intervenha somente quando achar necessário.

\section{Resumo}

Nosso olhar sobre o curso revela que a turma "EAV1":

- Começou como uma rede de aprendizagem online porque o curso reunia os participantes em rede e apresentava os seguintes elementos distintivos entre as redes do ciberespaço: objetivo educativo explícito, planejamento inicial e a presença do professor;

- Com o tempo, e graças às estratégias metodológicas aplicadas, os laços entre as pessoas estreitaram-se e o compromisso entre elas surgiu, provocando a transformação da rede em uma comunidade virtual de aprendizagem, que continha em si algumas subcomunidades;

- A formação da comunidade virtual de aprendizagem entre professora, tutores e alunos foi constatada a partir do mapeamento de alguns indicadores: reciprocidade permanente, compromisso implícito, iniciativa, informalidade, colaboração e intervenção pontual do professor;

- A comunidade virtual de aprendizagem "EAV 1" voltou a ser rede de aprendizagem na última unidade do curso porque alguns alunos optaram por produzir seus projetos de ensino online sozinhos (mas dialogando com a rede) e outros formaram comunidades para o cumprimento do desafio final.

\subsubsection{Olhares da professora e dos tutores}

“[...] o conhecimento avança à medida que o seu objeto se amplia, ampliação que, como a árvore, procede pela diferenciação e pelo alastramento das raízes em busca de novas e mais variadas interfaces". Concordando com a citação de Santos (2004, p. 76), que também 
acredita ser todo conhecimento total e local, tentamos ampliar nosso objeto de investigação e enriquecê-lo com outros olhares, alastrando as raízes da árvore que vimos desenhando. Para levantar as interfaces que pudessem cruzar e complementar a nossa, procuramos a professora e os tutores do curso "EAV1".

A entrevista com Vani Moreira Kenski foi realizada pessoalmente, gravada em áudio e transcrita a partir de um questionário que se assemelhava ao apresentado aos tutores do curso, mas com algumas perguntas distintas. A entrevista é um procedimento utilizado na investigação social para ajudar o diagnóstico que se constrói (MARCONI; LAKATOS, 1996).

Os tutores responderam a um outro questionário e nos encaminharam via e-mail. Segundo Selttiz (1965, p.273), o questionário é uma técnica bastante útil para obter informações acerca do que a pessoa "sabe, crê, sente ou deseja, pretende fazer, faz, bem como a respeito de suas explicações".

Entrevistamos a professora Vani Kenski a partir de uma lista de perguntas préelaborada. No entanto, durante a conversa, outras questões surgiram para melhor esclarecimento. A íntegra da entrevista pode ser lida no APÊNDICE B.

Os tutores Marcelo Gozzi, Teresa Jordão e Rodrigo Gabriel da Silva também estavam matriculados na disciplina e cursavam como alunos. O questionário e as respostas deles podem ser conferidos no APÊNDICE C, D e E, respectivamente.

Os tutores e a professora deram-nos informações a respeito do curso, dos bastidores e do que eles entendem ser uma comunidade, ampliando nosso objeto de investigação.As informações revelam que a colaboração entre os membros daquele curso resultou de um intenso trabalho de acompanhamento e de aplicação de estratégias para estimular a colaboração.

\section{Histórico do curso e dos ambientes}

A disciplina "Ensinando em Ambientes Virtuais 1" foi idealizada pela professora Vani Kenski a partir de pesquisas, experiências e disciplinas ligadas a formação de professores para o uso das tecnologias, além de cursos online de que ela participou no final da década de 90.

Em 2001, o curso foi apresentado à Comissão de Pós-Graduação da Faculdade de Educação da Universidade de São Paulo (USP). Com um formato até então inédito, uma vez que contemplava apenas quatro encontros presenciais, a disciplina foi oferecida nos anos de 2002, 2006 e 2008 com a mesma estrutura inicial. Apesar das unidades e dos temas já terem 
sido apresentados nesta dissertação, a explicação da professora a respeito das unidades expõe parte da estratégia de ensino:

1) Tecnologia: para os alunos vivenciarem e se sentirem à vontade com o ambiente;

2) Ensino: onde os alunos já iam perder toda essa liberdade de experimentar e de se sentirem confortáveis no ambiente. Eles iam se ajustar à regra porque a própria relação de ensino e aprendizagem é uma relação mais formal, mais fechada, mais estruturada. Eles podiam fazer algumas coisas que quisessem, mas dentro de alguns parâmetros baseados em teorias de aprendizagem;

3) Projeto: a maturidade que eles foram adquirindo neste processo dava a eles a autonomia que era requerida para chegar neste terceiro momento, ganhar asas e voar, fazerem seus próprios projetos. (APÊNDICE B).

O primeiro curso foi realizado em um ambiente chamado WebCT, o melhor que a professora diz já ter utilizado. A USP disponibilizava uma versão caseira traduzida, aproveitada pela disciplina apenas em 2002, uma vez que no curso seguinte a universidade não possuía mais convênio com a empresa proprietária do WebCT. A escolha de três ambientes diferentes para 2006 e 2008 pretendia tentar reproduzir a experiência do WebCT, que, de modo geral, oferecia recursos encontrados no TelEduc, no Col e no Moodle da SITE e do LabSpace (CoLearn).

Cada ambiente virtual é "orientado por um determinado tipo de lógica, de metodologia, de teoria de aprendizagem, que reflete muito a teoria dos seus idealizadores ou aquilo que eles pensam sobre a relação ensino e aprendizagem”, explica Kenski (APÊNDICE B). Ao mesmo tempo em que os alunos conferiam e discutiam as visões dos três ambientes pelos quais passavam, a professora utilizava os recursos e encontrava soluções para escapar de suas amarras e das especificidades técnicas que não estavam de acordo com sua metodologia colaborativa.

Em 2006, o curso previu que a primeira unidade seria por meio do TelEduc, "um ambiente extremamente didático, todo arrumadinho, certinho, com as suas gavetinhas, como é uma estrutura formal de ensino" (KENSKI, APÊNDICE B), desenvolvido e disponibilizado pela Unicamp. Mas o TelEduc saía do ar na sexta-feira e só retornava às segundas, para manutenção da USP, onde estava instalado. A solução encontrada pela professora, que já tinha uma empresa voltada para Educação a Distância, foi migrar os alunos para o TelEduc hospedado em sua empresa SITE.

O TelEduc, ligado ao servidor da SITE, continuou aberto para os alunos na segunda unidade, quando eles deveriam migrar para o ambiente Col, que pertence à USP, mas que fechava às sextas. Na $2^{a}$. unidade (Ensino) foi realizada no Col porque ele reflete a visão de 
Ausubel, que tem “(...) a proposta bem instruída de quem é professor, de quem é aluno e qual o papel do professor e do aluno. E o papel do aluno é o de responder aquilo que o professor pergunta. Não havia interação, era um ambiente muito mais difícil” (KENSKI, APÊNDICE B).

A última unidade do curso de 2006 aconteceu no Moodle, também hospedado na SITE, e, apesar de na época ser uma versão em inglês, os alunos tinham mais liberdade e recursos para trabalharem colaborativamente. A professora permitiu que cada aluno abrisse uma disciplina no ambiente, dando-lhes total autonomia para explorá-lo.

Na versão de 2008, o curso começou no Moodle da SITE, migrou para o TelEduc e terminou no LabSpace (CoLearn), também baseado na plataforma Moodle.

\section{Tutoria}

Desde a primeira versão, o curso contemplava a participação de tutores, embora a professora estivesse presente todo o tempo. Em 2008, a tutoria foi exercida por Marcelo Gozzi (doutorado), Rodrigo Gabriel da Silva (mestrado) e Teresa Jordão (doutorado), orientandos da professora Vani Kenski, sendo que os dois últimos cursavam o primeiro semestre da Pós-Graduação.

Sabemos que a palavra "tutor" possui especificidades na literatura de $\mathrm{EaD}$, mas, segundo a professora, o modelo de tutor nesse caso não é o corrente. O nome mais adequado seria "apoiadores", mas ela optou por "tutores" por esse ser mais conhecido dos alunos.

Antes de realizar as entrevistas, cogitamos a possibilidade de serem chamados de professores. Mas Kenski acha incorreto designá-los dessa forma, uma vez que ela concebeu e é a responsável pela disciplina, tendo elaborado todas as estratégias colaborativas empregadas. Os apoiadores eram auxiliares com algum tipo de atuação, contribuindo para a dinamização dos participantes.

Gozzi, Jordão e Silva distribuíram-se por diferentes grupos para que pudessem acompanhar o processo e passar informações à professora. Alguns participantes se comunicavam fora do ambiente designado para as unidades utilizando, por exemplo, $e$-mail e MSN, o que impedia a professora de acompanhar as discussões. Os informantes, sendo alunos, poderiam dizer a ela o que estava acontecendo nesses ambientes, como o líder do grupo se saía, quais as dificuldades técnicas, pedagógicas e de relacionamento enfrentavam. 
O trabalho dos tutores começou três meses antes do início da disciplina, com reuniões para que a professora pudesse expor a proposta do curso e planejar a atuação deles conjuntamente. A tutoria era compartilhada entre os três orientandos, que se revezavam semanalmente, quando os desafios eram apresentados à comunidade. Os quatro mantinham contato freqüente, "visando conseguir um acompanhamento efetivo das ocorrências em todos os instantes da disciplina, para correção e ajustes nos rumos”, segundo Gozzi (APÊNDICE C)

Nessas reuniões, diz Jordão, "conforme os objetivos da disciplina naquela semana, eram definidas as estratégias e elaboradas as ações de cada tutor, a partir da observação dos alunos na realização das atividades da semana anterior" (APÊNDICE D). Kenski completa explicando que nesses encontros, eles também aprendiam o seu modo de atuação, além de ser “uma orientação em serviço", já que eram reuniões de orientação e de discussão. Mas eles não tinham poder de definição da disciplina, nem de ordem pedagógica, por isso não poderiam ser chamados de professores, acredita a responsável pelo curso.

Durante o processo, os tutores opinavam, construindo junto com a professora. Partiase do que já estava acontecendo e sendo discutido, embora tivessem total liberdade para atuarem na semana sob sua responsabilidade por meio da interação com os alunos. "Algumas vezes nós conversávamos em paralelo ‘olha, fulano disse isso. Vai lá, pega aquilo e fala'. Ou, então, ninguém está falando nada. 'Vai lá e bota pergunta'”, diz Kenski (APÊNDICE B)

A intensidade do trabalho dos tutores e da professora variava de acordo com a participação dos alunos e o ambiente. Como na última unidade, o LabSpace/CoLearn ainda não havia sido usado nas versões anteriores do curso, os três tiveram um desafio maior e contaram com a ajuda de representantes do CoLearn, Alexandra Okada e Saburo Okada. Juntos, eles prepararam o ambiente duas semanas antes da $3^{\text {a }}$. unidade, mapeando as possibilidades e conhecendo as ferramentas.

Os tutores também figuravam como um meio de campo entre os alunos e a professora nos casos em que os participantes não se sentiam à vontade para falar diretamente com ela resquícios da cultura educacional que coloca o professor em um pedestal.

Eles destacam o duplo papel como experiência significativa, podendo olhar o processo por ângulos diferentes. Ser "alunos nos ajudou a pensar em estratégias que suprissem determinadas lacunas que surgiram durante o curso. $O$ planejamento durante a ação foi facilitado por esta observação" (JORDÃO, APÊNDICE D). Para Silva, apresentar “conceitos e indagações era o mais interessante desta função, pois, diversas respostas eram dadas e comentadas por todos. Um rico material teórico" (APÊNDICE E). 
"Como tutor, desenvolvi bastante a prática da mediação pedagógica, aprendendo a necessidade de acompanhar constantemente o que acontece com todo o grupo, ficando atento aos detalhes, pois são dotados de um enorme potencial para o desenvolvimento do curso", analisa Gozzi (APÊNDICE C). Ele ressalta que o papel do mediador/tutor como um elemento importante para a motivação e o desenvolvimento da aprendizagem em uma disciplina ofertada a distância, desde que seja presente e ativo.

Os alunos não conheciam essas identidades e, segundo a professora, não suspeitavam que os tutores fossem mais de um. "Tratavam como se fosse alguém que não estava infiltrado na turma. Quer dizer, o nível de percepção desenvolvido no grupo no ensino online precisa ser apurado.” (KENSKI, APÊNDICE B).

\section{Comunidade virtual de aprendizagem?}

Meu olhar como aluna-pesquisadora indicou que o curso EAV1 começou como uma rede de aprendizagem online e, com o desenvolvimento das relações sociais e do processo educativo, transformou-se em uma comunidade virtual de aprendizagem, que voltou a ser rede na unidade 3.

Essa é apenas uma interface deste objeto de pesquisa. $\mathrm{O}$ entendimento do que são redes e comunidades virtuais de aprendizagem, como vimos tratando, mostra-se bastante complexo. A entrevista com a professora e o questionário respondido pelos tutores expõem a ampliação que buscávamos, uma vez que os entrevistados apontam outros entendimentos.

O olhar da professora assemelha-se ao nosso, mas há distinções. Vani Kenski concorda que o curso começou como uma rede de aprendizagem e, na unidade 2 (Ensino) os alunos constituíram uma comunidade virtual de aprendizagem e outras várias (que chamamos de subcomunidades), desfeitas na $3^{\text {a }}$. unidade.

No entanto, a comunidade teria existido apenas em alguns momentos, não em toda $2^{\mathrm{a}}$. unidade. Para a professora, uma comunidade pode durar uma semana, dois dias, uma ação para completar um determinado desafio... Ou seja, em situações específicas e como conseqüência de um processo em ebulição que atinge um ponto ótimo. "Eu vejo que o momento da construção da comunidade foi entre o $2^{\mathrm{a}}$. e o $3^{\mathrm{o}}$. desafio da $2^{\mathrm{a}}$. unidade. Foi o momento em que eu senti que os alunos estavam integrados, que estavam no desafio e procurando resolver alguma coisa. Mas não a disciplina como um todo" (APÊNDICE B). 
Esses momentos poderiam ser percebidos por meio da interação e das ferramentas de acompanhamento do ambiente virtual.

[...] você sente quando a comunidade constrói, quando no wiki todo mundo está ali colocando uma corzinha e produzindo texto. Quando no fórum, um complementa o outro e existe interlocução, e não uma pergunta-resposta ou uma fala de surdos, onde um fala uma coisa, outro diz outra e outro diz outra. Onde existe engajamento, onde as pessoas estão se entendendo e o que uma fala é para construir, para complementar o que outra já disse, é para amadurecer a idéia e elas estão juntas refletindo sobre alguma coisa. Estão juntas construindo alguma coisa. Aí você tem realmente uma comunidade, um grupo com objetivo definido e que, a realização desse objetivo, acrescenta muito para cada um dos que estão participando. É um movimento. E justamente por ser movimento ele não pode se cristalizar, ele não se cristaliza. (KENSKI, APÊNDICE B).

No "momento" da comunidade de aprendizagem, as relações, o conhecimento, o comportamento, os valores, as atitudes, os hábitos amadureceram por meio da superação de um desafio que não está neles, é provocado pelo professor. Torna-se uma comunidade de aprendizagem quando seus integrantes atingem os princípios do construcionismo e da abordagem colaborativa de aprendizagem.

No fórum, por exemplo, os participantes não apenas trocam idéias. "Trocar idéia não significa se preocupar com o outro e construir com o outro" (KENSKI, APÊNDICE B), mas discutem de modo a se complementarem, a partir do que cada um sabe. Por isso, o fórum de uma comunidade de aprendizagem seria uma conversa, e não respostas dos alunos à pergunta feita pelo professor.

Uma comunidade de aprendizagem é diferente de um trabalho em equipe. Para chegar à comunidade:

[...] nós temos que superar, ir muito além da relação de laços afetivos e de conhecimento. Nós temos que ter valores, temos que ter respeito ao outro, temos que ter atitudes, temos que ter habilidades, e outros tantos comportamentos que sejam significativos para que essa comunidade aconteça. Se a gente pensar só em laços afetivos e conhecimento a gente continua na equipe. Não sai disso: eu sou amiguinha de você, temos que fazer o trabalho da professora tal. Então você faz a capa e eu faço o conteúdo, você faz o capítulo 1 e eu o 2. Depois a gente reúne para fazer as considerações finais e pronto. Isso daí não é comunidade! Por isso, comunidade é uma coisa muito difícil de ser alcançada. Exige uma mobilização de sentidos muito maior, de expectativas, de muitas coisas para poder se chegar naquele movimento. (KENSKI, APÊNDICE B, grifo nosso).

Para Kenski, a existência de laços e a construção coletiva de conhecimento não seriam suficientes para a criação de uma comunidade virtual de aprendizagem. Seria necessária uma transformação maior. "É alguma coisa que se plantou como algo construído, como algo 
aprendido, em todo o sentido da palavra que significa aprendizagem, que envolve, no caso de Delors, aprender a ser, aprender a conhecer, aprender a fazer... Esse é o grande processo que está envolvido, e aí é gigante" (APÊNDICE B).

Como a professora, o tutor Marcelo Gozzi ${ }^{42}$ acredita que várias comunidades de aprendizagem foram constituídas no curso "EAV1" em momentos diferentes. Mas com uma permanência maior. Algumas, com duração até o final de alguma atividade proposta. Outras, que duraram o curso todo e, ainda, após seu encerramento. Gozzi considera, em linhas gerais, a existência de uma comunidade de aprendizagem quando há objetivos comuns, as pessoas sentem-se pertencentes à comunidade e quando existe o sentimento de co-responsabilidade quanto aos resultados. "(...) Podemos afirmar que houve vivência em comunidades de aprendizagem através da disciplina" (APÊNDICE C).

Rodrigo Silva também acredita que o objetivo da disciplina de proporcionar a vivência em comunidade virtual foi alcançado. "Creio que foi constituída uma comunidade virtual de aprendizagem pelo fato dos trabalhos e da união que os grupos demonstraram ter conquistado na última aula presencial e como todos se conheciam e se comunicavam sem pensar em tempo e distância" (APÊNDICE E).

Kenski, Gozzi e Silva concordaram com a formação de comunidade(s) virtual(is) de aprendizagem no curso, embora apresentem distinções quanto à duração e entendimento do que elas sejam. Já a tutora Teresa Jordão não acredita que a "EAV1" tenha constituído uma ou várias comunidades de aprendizagem porque possui outro entendimento da natureza desses agrupamentos. "Na minha opinião pessoal, uma comunidade virtual só existe realmente quando ela se mantém mesmo sem a presença formal de um líder (professor) ou sem uma estrutura formal (disciplina). Portanto, "EAV1" não deve ser considerada uma comunidade virtual de aprendizagem.” (APÊNDICE D).

\section{Liderança}

Jordão defende que qualquer pessoa pode assumir a liderança, inclusive várias pessoas em momentos diferentes. "A liderança compartilhada é uma maneira de conseguir engajamento dos membros e motivação para que continuem participando ativamente da

\footnotetext{
${ }^{42}$ Vale ressaltar que o tutor já havia desenvolvido uma pesquisa a respeito de comunidades de aprendizagem em sua dissertação de mestrado: GOZZI, Marcelo Pupim. A construção de um projeto coletivo em uma comunidade virtual de prática. 2006, 282 p. Dissertação (Mestrado em Educação, Arte e História da Cultura), Universidade Presbiteriana Mackenzie, São Paulo.
} 
comunidade" (APÊNDICE D). O líder teria como característica principal grande envolvimento e motivação junto à comunidade.

Gozzi, embora também considere a possibilidade da liderança ser exercida por qualquer membro de uma comunidade virtual de aprendizagem, de acordo com "determinadas características pessoais", diferencia esse papel do executado pelos professores e tutores. Estes conheceriam as abordagens colaborativas em processos educacionais. “[...] um profissional devidamente capacitado deve estar acompanhando todo esse processo para garantir o objetivo e a vida da comunidade, considerando o fim para qual ela foi criada" (APÊNDICE C).

De modo geral, Kenski concorda com Gozzi ao defender a necessidade de um líder porque, para ela, o processo de aprendizagem exige um caminho, uma meta e alguém que faça esse processo caminhar, que tenha uma definição de processo. Mas as características dessa pessoa dependeriam da comunidade:

\begin{abstract}
Mesmo sendo comunidade de aprendizagem, depende de foco, depende de objetivo, depende do perfil do grupo. Não há como a gente definir uma regra geral. Comunidade de aprendizagem é um nome extremamente amplo para qualquer coisa, para tudo aquilo que se faz em grupo com intuito de aprender dentro de um ambiente virtual. E aí você pode ter grupos totalmente autônomos, onde cada um tem um nível de conhecimento altíssimo e pode de certa forma conduzir o processo em um determinado momento e passar o bastão pro outro como você pode ter comunidades totalmente heterogêneas e que tem uns que predominam tem outros que não, tem os grupinhos, tem de tudo. Mesmo grupo de pesquisa, autônomos, sérios, a coisa se fractaliza, se distribui. Acho que a comunidade de aprendizagem ela precisa ter uma liderança porque o processo de aprendizagem exige um caminho, uma meta, ele tem um objetivo definido e precisa ter alguém que faça esse processo caminhar, que tenha realmente uma definição de processo. (KENSKI, APÊNDICE B)
\end{abstract}

Além dos tutores e da professora, o curso possuía líderes de grupo, que mudavam a cada desafio semanal dentro do seu próprio agrupamento. Essa liderança era provocada, uma estratégia para motivar os alunos e estimular a colaboração, lembrando que a proposta da disciplina só é possível ser realizada com a participação efetiva dos alunos no ambiente virtual. Para Kenski, os líderes do curso foram fundamentais para estimular a participação, além de proporcionar aos alunos exercitarem a articulação entre as pessoas, já que todos foram líderes.

Tanto a liderança nos grupos quanto a existência da professora e dos tutores empregando estratégias colaborativas seriam de fundamental importância para "provocar" a formação da comunidade. "Sem a adoção de estratégias que visavam viabilizar a aproximação e instigar a participação dos participantes da disciplina, a formação de uma comunidade 
virtual de aprendizagem ficaria comprometida, podendo até não ocorrer." (GOZZI, APÊNDICE C).

\section{Abordagem construcionista}

A sociedade atual tem exigido uma nova cultura, com valores, atitudes e comportamentos diferentes da individualista, na qual somos educados. A maioria dos processos de ensino e aprendizagem é fragmentada, contempla uma avaliação isolada e solitária, como o estudo individual dos alunos e o próprio trabalho docente. O curso tentou, por meio da constituição de comunidade(s), proporcionar aos discentes o desenvolvimento de uma cultura colaborativa.

A estrutura do curso fundamenta-se teoricamente na proposta de currículo em espiral de Bruner (1973), que consiste em sucessivas abordagens de conceitos-chave pelos alunos, sempre em ordem crescente de complexidade.

\footnotetext{
O currículo vai em espiral em diferentes movimentos: o da prática, do processo, da vivência. Então a cada movimento existe uma integração, que vai do individual para o grupal.[...] $\mathrm{Na}$ verdade os desafios, se você notar, normalmente eles tinham a mesma relação. Eles vinham sempre do mesmo processo: era um desafio individual, que se baseava numa reflexão, essa reflexão encaminhava para o desafio grupal, que encaminhava para uma resposta, que caminhava para os comentários com as pessoas já mais amadurecidas. Quer dizer, você ter um olhar externo para a sua produção, senão você fica fechadinho na sua comunidade. E aí você vê o princípio dialético de você ter uma questão, uma pergunta, trabalhar para analisar aquilo, ter a resposta, que vai te dar o que? Novas perguntas e você vai reelaborar o processo todo. Só que esse currículo em espiral vai se adensando e se aprofundando. Ele começa lá em cima com as tecnologias. Dentro dessa metodologia, num outro processo, ele vai continuar acontecendo desse mesmo jeito, mas com outras questões, cada vez mais profundas, até você chegar no aprofundamento dentro do seu próprio projeto, da sua própria questão, daquilo que de certa forma você está interessado em aprender, ir além ou aplicar tudo aquilo que já foi aprendido nos momentos anteriores. (KENSKI, APÊNDICE B).
}

A espiral começava com o desafio individual, que era o momento da introspecção, da intra-comunicação, quando cada participante lia e pensava individualmente a respeito de um tema e apresentava uma resposta individual. Depois, essa resposta era levada para o grupo, que tinha outro desafio quanto à mesma questão para resolver em conjunto.

A resposta grupal, por sua vez, tinha que ser explicitada e socializada com os alunos dos demais grupos para entrar na "visão do mundo". O passo seguinte era receber e dar um retorno às respostas dos outros grupos. 
Na primeira unidade, por exemplo, um dos desafios era os participantes produzirem um mapa de suas próprias vidas, que deveriam formar um mapa do grupo, apresentado e comentado pelos colegas. O desafio grupal na semana seguinte era mais complexo: produzir um $w i k i^{43}$ colaborativamente sobre um dos temas apresentados pela professora.

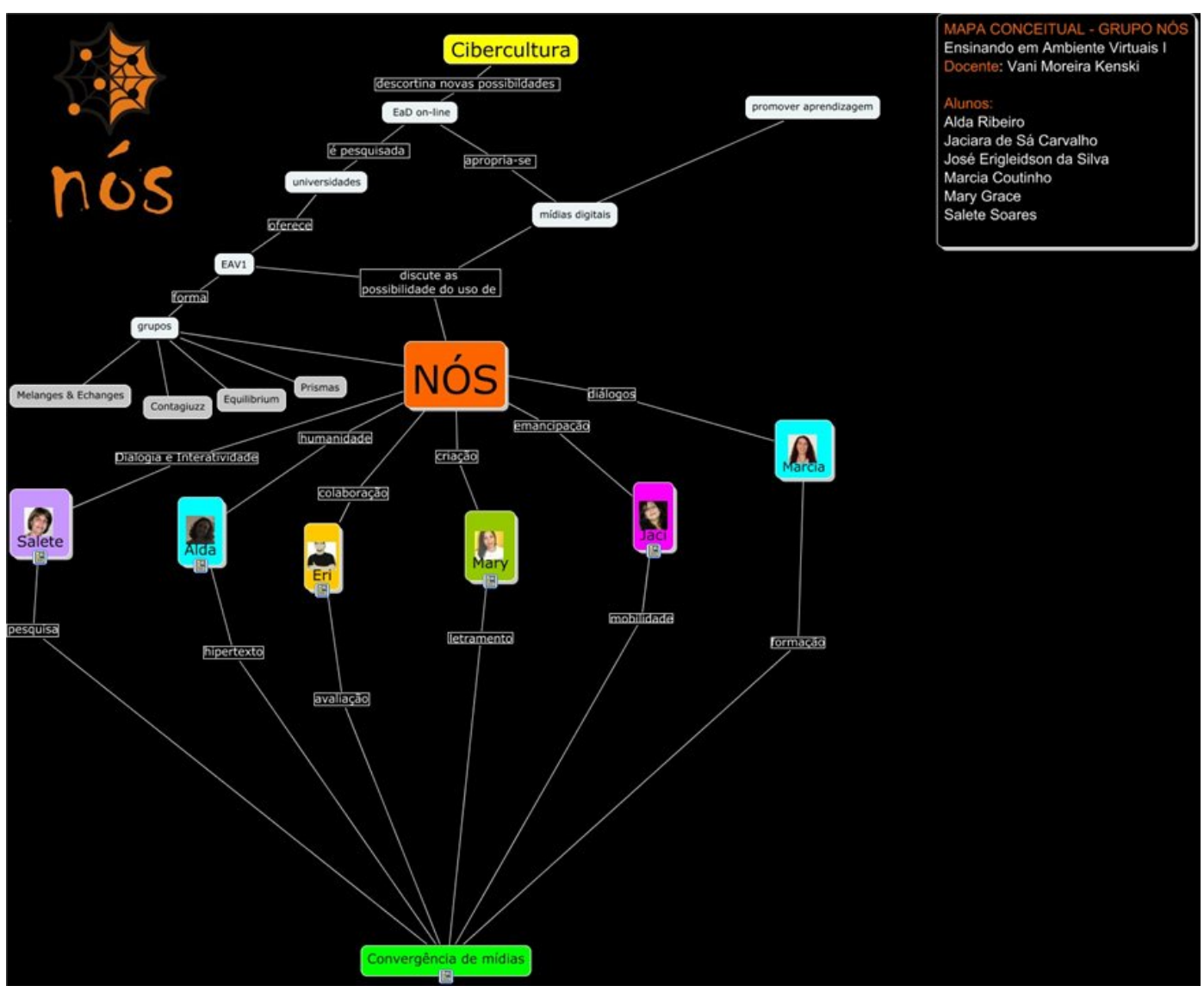

Figura 25: Mapa que apresentou o Grupo Nós e seus integrantes Fonte: Reprodução

A disciplina desenvolve-se com o aprofundamento dos conceitos e a utilização de ferramentas e ambientes cada vez mais complexos, "até o ponto em que você supera as ferramentas, passa a estar no lugar dela e entende que está ali para ajudar você a aprender mais e melhor e fazer com que haja uma maior interação entre você e todos" (KENSKI, APÊNDICE B).

Além de Bruner, o cursou baseou-se, principalmente, em outros dois autores: Lévy (1998), que trata dos processos de construção da inteligência coletiva, e Kerckhove (1997),

\footnotetext{
${ }^{43}$ Wiki é "[...] um tipo específico de coleção de documentos em hipertexto ou o software colaborativo usado para criá-lo. [...] Chamado "wiki" por consenso, o software colaborativo permite a edição coletiva dos documentos usando um sistema que não necessita que o conteúdo tenha que ser revisto antes da sua publicação." Disponível em: <http://pt.wikipedia.org/wiki/Wiki>. Acesso em: 01 mar. 2009.
} 
quanto à "construção da web, daquele grupo de pessoas que estão preocupadas em aprender e construir algo juntas, que têm interesses e que seja importante para elas" (KENSKI, APÊNDICE B).

A construção de conhecimento durante o curso acontece essencialmente nos grupos, que precisam resolver os desafios apresentados semanalmente. A organização do trabalho em agrupamentos na $1^{\mathrm{a}}$. unidade permitiu aos participantes vivenciar um processo de ruptura na $2^{\mathrm{a}}$. unidade, quando novos grupos precisaram ser formados, de modo que os alunos não ficassem com os mesmos parceiros da unidade anterior.

Esse movimento significou uma ruptura porque as pessoas entraram em um estado de desequilíbrio. Elas haviam iniciado o curso e não se conheciam. Formaram os grupos e durante um mês construíram relações de confiança e amizade. Quando finalmente esses laços estavam estreitos, a professora pediu para que os participantes se separassem, migrando para outros grupos.

A nova organização seguiu o princípio da cosmo-visão já que cada integrante representava a história do grupo do qual emergiu. Ao mesmo tempo, os alunos tinham a oportunidade de experimentar um processo de mudança: “[...] existe todo um discurso pedagógico dizendo que tem que se preparar para a mudança, mudança, mudança. É viver a mudança na sua própria história!” (KENSKI, APÊNDICE B).

\subsection{Uma costura final}

Nunca será possível vislumbrar todas as interfaces de um objeto. Cada olhar é produzido a partir de experiências pessoais, dos conceitos que se constrói, de emoções e uma série de outras variáveis.

Ao investigarmos um objeto, realizamos um conjunto de relações específico a partir da seleção e rejeição de elementos que dele apreendemos. Assim como a realidade objetiva ${ }^{44}$, somos seres complexos, mas incapazes de abrangê-la por completo. Vivemos na subjetividade, a realidade que cada um de nós é capaz de compreender sobre a outra (MORENO et al, 1999).

Nosso olhar expõe um "modelo organizador do pensamento" que a nós é específico. Ou seja, uma "particular organização que o sujeito realiza dos dados que seleciona e elabora a

\footnotetext{
${ }^{44}$ Segundo Moreno et al. (1999), a realidade objetiva é a que serve de referência aos modelos organizadores que o pensamento constrói.
} 
partir de uma determinada situação, do significado que lhes atribui e das implicações que deles se originam.” (MORENO et al, 1999, p. 78). Conseqüentemente, não abstraímos do objeto dados que podem ser, em muitos casos, fundamentais para explicá-lo.

As entrevistas com a professora e os tutores do curso "EAV1" apresentam alguns dados novos que, relacionados aos já apreendidos, nos permitem elaborar um outro modelo a partir da mesma situação (MORENO et al, 1999). Ele ainda é restrito e sempre será já que os dados considerados neste novo modelo e ignorados em outro, “[...] não podem ser relacionados entre si, dando lugar a um fenômeno muito semelhante ao produzido nas centrações: ainda que um sujeito possa realizar sucessivamente diferentes centrações, não pode tornar todas simultâneas, já que cada uma exclui as restantes." (1999, p. 367).

Conscientes dessas limitações humanas, o modelo reelaborado passa a compreender as comunidades virtuais de aprendizagem como agrupamentos que resultam de um trabalho intenso do professor e das demais pessoas que se responsabilizam por fazer os participantes alcançarem os objetivos propostos.

A capacidade do professor de adotar estratégias que estimulem a colaboração entre os participantes ganha maior relevância a partir das entrevistas. Parece-nos que dificilmente uma comunidade de aprendizagem pode surgir espontaneamente, sem as provocações do responsável, sem uma mediação eficaz e um planejamento inicial que promova o estreitamento de laços. Tão importante quanto o planejamento, seria o acompanhamento minucioso das interações e das ausências verificadas no ambiente.

A passagem de rede para comunidade virtual de aprendizagem seria o "ponto ótimo" de um processo sóciolingüístico complexo, que modifica as relações entre os participantes e as próprias pessoas. Embora concordemos com Kenski quanto à transformação do ser, parecenos exigir demais restringir a comunidade a momentos específicos de ação. Se houve verdadeiramente um estreitamento de laços e uma modificação de valores e atitudes nos participantes, a fugacidade não nos parece estar de acordo com tamanha transformação.

As entrevistas também nos fazem perceber que, apesar das pessoas estarem em rede e, nela, todos os nós têm a mesma relevância, a liderança contribui para a mobilização das pessoas, que possuem interesses, motivações, valores e comportamentos únicos e precisariam ser potencializados para maior participação.

Uma comunidade virtual de aprendizagem não torna as pessoas uma massa homogênea, nem espera que elas aprendam o mesmo de forma idêntica. Pelo contrário, respeita as individualidades, o tempo e os processos de cada um, entendendo que as diferenças contribuem para o crescimento de todos. 
Obviamente, esse modelo de pensamento resulta não só da análise da "EAV1" e de outras redes sociais e de aprendizagem contempladas nesta dissertação, mas também de outras que conhecemos e que se constituem dados para esta organização particular. Afinal, não podemos nos desligar da realidade que conseguimos enxergar e que extrapola esta pesquisa. 


\section{CONSIDERAÇÕES FINAIS}

\subsection{A motivação}

4.2 Antes de tudo, as pessoas e a interação

4.3 Revendo os objetivos da pesquisa: elementos distintivos 


\section{CONSIDERAÇÕES FINAIS}

Chegou o momento de recuperar, de forma resumida, o que foi construído ao longo dos capítulos. Retomamos as motivações e o objetivo da pesquisa e os confrontamos com o desenrolar da investigação para saber se conseguimos obter algumas respostas. Seria uma espécie de arremate da costura feita, sem concluí-la.

\subsection{A motivação}

Após tecermos uma rede de pensamentos, autores e prática, chegamos ao arremate. Mas ele não significa conclusão, e sim um reforço para essa costura, recuperando os objetivos iniciais desta investigação e os nós dos capítulos.

Há algum tempo, vivemos sob a perspectiva de que nenhuma teoria é completa e definitiva. Na complexidade da rede que a ciência navega, esta dissertação é apenas uma perspectiva que interage com outras e pode ser alterada a qualquer momento; afinal, é dependente dos elementos que a compõem. Como parte de um mundo de interações, qualquer mudança pode influenciar a dinâmica investigada, um experimento comprovado, as características estabelecidas.

Ao iniciar esta pesquisa, pretendíamos responder às seguintes questões, explicitadas na Introdução deste trabalho:

- Como distinguir as redes e comunidades virtuais de aprendizagem das demais comunidades e redes sociais do ciberespaço?

- De que maneira pode-se perceber a formação de uma comunidade virtual em uma situação de aprendizagem em rede?

A problemática surgiu por meio do incômodo que sentíamos quanto ao uso indiscriminado das expressões rede e comunidade virtual de aprendizagem nos projetos de Educação online em que atuávamos. Não se trata se preciosismo, mas de sabermos que as palavras são signos ideológicos e que seu uso formata a realidade (BAKHTIN, 1981). Se nossos pensamentos só existem por intermédio de signos, conhecer que realidade essas 
expressões dão forma contribuiria para agirmos mais criticamente em projetos educativos desenvolvidos no ciberespaço.

No início, suspeitávamos que cada expressão designasse uma realidade distinta porque observávamos dinâmicas diferentes entre os agrupamentos online voltados à aprendizagem. Também percebíamos diferentes graus de interação e laços entre os participantes dos agrupamentos com intencionalidade educativa.

Nossa investigação indica que existem distinções entre a) as redes e comunidades virtuais de aprendizagem entre si; e b) em relação aos demais agrupamentos do ciberespaço. Ao longo dos capítulos, costuramos as diferenças a partir de algumas características mapeadas. Iluminando pontos, tentamos formular uma idéia mais clara de quando empregar cada expressão e em que momentos há intersecção. A linha usada nessa costura é a das interrelações e dos vínculos, pois sem eles não há rede e muito menos comunidade. "As propriedades já não estão nas coisas e sim entre as coisas, no intercâmbio."45, diz Najmanovich (1995, p. 65, tradução nossa).

\subsection{Antes de tudo, as pessoas e a interação}

Este trabalho valoriza as redes de pessoas, seus projetos e valores em um contexto marcado pela crescente inovação tecnológica. Ressalta a interação como condição sine qua non para a constituição de redes sociais no ciberespaço, principalmente as que apresentam intencionalidade educativa.

Essa condição pode parecer óbvia em se tratando de rede de pessoas, mas não poderia porque diversos ambientes do ciberespaço reúnem participantes, mas nem sempre há interação. Eles estão interligados pelas ferramentas, aparecendo uns aos outros de forma assíncrona (por meio de imagens e textos publicados). No entanto, o diálogo pode ser pouco exercitado. Nem sempre há ação, quiçá comunidade, onde a interação seria freqüente.

O enfoque sobre as redes de pessoas estaria alinhado à crítica feita por Postman (1994), Freire $(1979,1996)$ e outros autores que contribuíram com este trabalho. Eles colocam o ser humano à frente da tecnologia, não subjugando a ação e os desejos humanos ao discurso tecnológico inquestionável, que torna o homem maravilhado com o poder de criar.

\footnotetext{
45 “Las propiedades ya no están en las cosas sino entre las cosas, en el intercambio.” (NAJMANOVICH, 1995, p.
} $65)$. 
No CAPítulo 1, colocamos em destaque o ciberespaço como meio para ampliar a comunicação humana, valorizando, portanto, a inovação tecnológica. Mas em vez de destacar a tecnologia em si, o ciberespaço é tratado por meio das redes de pessoas que o construíram, seus desejos e valores. Alguns desses agrupamentos contribuem para que ainda possamos encontrar no ciberespaço os sonhos iniciais de liberdade que constantemente se confrontam com interesses comerciais e de poder. Eles também indicariam a vocação do ciberespaço para abrigar redes e comunidades virtuais.

No mesmo capítulo, ressaltamos a mudança e a instabilidade de conceitos como comunidade e rede social. Na comunidade, os laços entre as pessoas seriam estreitos, haveria um sentimento de compromisso entre elas, que também colaborariam com freqüência. Assumimos essa distinção, no entanto, sem considerá-la irreversível. Como pesquisadores sociais, lidamos com relações humanas sem a ingenuidade de acreditar ser esta uma investigação objetiva. Não descobrimos algo novo, apenas redescobrimos o que outros “ouviram" e precisam fazê-lo de novo, preferindo a busca da verdade à exatidão em seu sentido técnico (POSTMAN, 1994).

A reflexão do CAPÍTULO 1 foi realizada a partir de uma perspectiva histórica, que não se restringiu à criação do ciberespaço. Para tecermos um entendimento sobre comunidade virtual fomos da pólis grega à idéia de comunidade na pós-modernidade, incluindo uma compreensão sobre a palavra virtual. Seria um modo de estabelecer um "senso de sentido ao que sabemos e de como sabemos" (POSTMAN, 1994, p. 195). A recuperação histórica, embora bastante resumida, permitiria que não considerássemos o homem "criador do mundo" (VIEIRA PINTO, 2005), e sim o histórico que ainda se liga ao universo.

\subsection{Revendo os objetivos da pesquisa: elementos distintivos}

O destaque para a ação entre os homens, por meio da tecnologia, continua no CAPÍTULO 2, quando apontamos os elementos que distinguiriam as redes e comunidades de aprendizagem das demais do ciberespaço, tendo consciência de que a aprendizagem ocorre em qualquer lugar, tempo e circunstância.

Diferenciamos redes e comunidades virtuais de aprendizagem das demais redes sociais e comunidades online por elas apresentarem características de um processo de ensino, já que 
existe um esforço intencional e organizado para que os participantes possam alcançar a aprendizagem a que se propõem.

As redes de aprendizagem online seriam agrupamentos localizados no ciberespaço a partir de uma proposta inicial. Seus integrantes interagem durante um processo de ensino, que, portanto, contempla a figura do professor. Os participantes têm liberdade para expor idéias, questionamentos e apresentar novas proposições porque a relação entre educadores e alunos é mais horizontal e dialógica.

Como base para o desenvolvimento de projetos em redes de aprendizagem online, a metáfora do conhecimento como "rede de significações", a partilha de um projeto coletivo e a intencionalidade educativa, temas a que Machado $(2000,2004,2005)$ tem se dedicado. O autor também subsidia a importância dada neste trabalho à participação do professor em um contexto em que muitos acreditam ser dispensável, uma vez que a idéia de rede está atrelada à de simetria, de pares. Não somos contrários a essa idéia, que corroboramos. Mas ressaltamos que a relação de igualdade, em situação de aprendizagem visando ao cumprimento de um projeto, exigiria assimetria em alguns momentos.

Qualquer pessoa da rede poderia ser professor desde que apresente algumas competências. O professor que aqui tratamos seria o mesmo defendido pela maioria das concepções pedagógicas desde meados do século passado, contrária à transferência de conhecimento e que entende o docente como um potencializador da aprendizagem e também como um discente. $\mathrm{O}$ desafio continua sendo o professor conseguir tecer significações, mediar relações, mapear relevâncias, narrar, ser tolerante e ter autoridade. Essas competências defendidas por Machado (2004, 2009) são similares às apontadas por Freire (1996), para quem ensinar exige respeito aos saberes e à autonomia do educando, a substituição da palavra pelo exemplo, a reflexão e crítica sobre a prática, liberdade e autoridade, diálogo.

Mas apesar das mesmas competências, a ação do professor no ciberespaço precisa ser reconfigurada. Como um cartógrafo, ele mais aponta onde os participantes podem encontrar respostas do que as entrega; mais mobiliza a rede para realizar um projeto do que concentra as atenções sobre si; e, principalmente, adota estratégias para estimular a interação entre os participantes, uma vez que, em situação de aprendizagem, não seria fácil encontrar participação.

Por vontade própria, mas também estimulado por políticas públicas, o professor-autor (PRETTO, 2007) poderá descobrir como ensinar usando ferramentas tecnológicas, sem considerá-las apenas animadoras do processo de ensino. No entanto, para isso, seria necessária uma "aguda consciência em relação à natureza cultural das máquinas e suas 
linguagens" (SCHWARTZ, 2007). Pretto e Assis (2008, p. 82) apostam na organização em rede e em "um forte repensar dos valores, práticas e modos de ser, pensar e agir da sociedade" para que a articulação entre cultura digital e a Educação seja concretizada. Certamente a ação do professor no ciberespaço é tema de diversas pesquisas e, nesta, não pudemos abordar o assunto com a profundidade com que gostaríamos.

A ação do professor, a análise da rede de aprendizagem online "POIEs do Butantã"46 da proposta inicial da "Comunidade de Gestores" no CAPÍTULO 2 contribui para mapearmos elementos distintivos das redes virtuais de aprendizagem em relação aos demais agrupamentos do ciberespaço:

\section{- Objetivo educativo explícito}

\section{- Professor (es)}

\section{- Proposta / projeto inicial}

As comunidades virtuais de aprendizagem também apresentariam esses elementos, mas os laços entre os participantes seriam mais estreitos, desencadeando certo compromisso e freqüente colaboração. Essas características puderam ser analisadas no CAPÍTULO 3, quando examinamos o curso online "Ensinando em Ambientes Virtuais 1" (EAV 1).

Gostaríamos de enfatizar que neste trabalho não há julgamento de valor quanto à distinção apresentada. "Comunidade de aprendizagem" não seria mais importante do que "rede de aprendizagem" e vice-versa. Esses agrupamentos atendem a dinâmicas diferentes, mais amarrados ou fluidos, de acordo com as necessidades e características de seus participantes. E, nos dois casos, pode-se chegar aos objetivos de aprendizagem préestabelecidos.

A análise do curso contribuiu para observarmos outra dinâmica, até por ser uma disciplina oferecida em pós-graduação que durou quatro meses e contou com avaliação. Portanto, mais "amarrada" do que a rede "POIEs do Butantã", mantida ao longo de 2008 e cujos participantes não corriam o risco de serem reprovados porque não se tratava de um curso.

Diante do entendimento que tecemos, os cursos online só poderiam ser considerados redes de aprendizagem se os participantes interagirem e se houver abertura para novas proposições. Em uma rede de aprendizagem online, apesar da presença do professor, o

\footnotetext{
${ }^{46}$ A análise da rede social "Blogs Educativos", no capítulo 1, e a comunidade virtual de aprendizagem "Ensinando em Ambientes Virtuais 1" (EAV 1) também contribuíram para elencar os elementos distintivos.
} 
processo de ensino não pode ser diretivo e fechado, e sim abrir espaço para o compartilhamento de decisões importantes para a aprendizagem de todos. Quando há colaboração freqüente e compromisso entre os participantes do curso, além dos demais elementos das redes de aprendizagem online, os integrantes formariam uma ou várias comunidades virtuais de aprendizagem.

A análise do curso EAV1 também contribuiu para mapearmos indicadores de constituição de uma comunidade entre participantes em situação de aprendizagem em rede:

\section{- Reciprocidade permanente;}

- Compromisso implícito;

- Iniciativa;

- Informalidade;

- Colaboração freqüente;

- Intervenção pontual do professor.

A intervenção pontual do educador seria resultado dos outros indícios, que são valores e levam à formação de um grupo coeso e compromissado com a aprendizagem. $\mathrm{O}$ que de modo algum significa ausência do professor. Pelo contrário, a pesquisa mostra-nos que as comunidades virtuais de aprendizagem exigem um trabalho intenso para estimular a colaboração entre os participantes e estreitar laços. A intervenção diz respeito ao grau de exposição do professor quanto a chamar as pessoas para a aprendizagem; "cobrar" participação seria menor nas comunidades do que nas redes. No entanto, dificilmente uma comunidade de aprendizagem pode surgir espontaneamente, sem o trabalho de "bastidor" do professor visando a colaboração.

Vemos que nossos objetos de pesquisas, as redes e comunidades virtuais de aprendizagem, se inter-relacionam. Mas tentamos mostrar que o intercâmbio não significa deixar de lado a distinção. Najmanovich, ao tratar da superação das leis deterministas, ressalta:

\footnotetext{
"Mas, uma vez aceitada a diversidade, se faz possível e necessário um intercâmbio fecundo, uma "fertilização cruzada" que só pode se dar na condição de reconhecer os âmbitos de pertencimento, a diversidade e sua legitimidade; porque não devemos confundir interação com indistinção ${ }^{47, "}(1995$, p. 71 , grifo e tradução nossa).
}

\footnotetext{
47 "Pero, una vez aceptada la diversidad se hace posible y necesario un intercambio fecundo, una 'fertilización cruzada' que solo puede darse a condición de reconocer los ámbitos de pertenencia, la diversidad y su legitimidad; porque no debemos confundir interacción con indistinción.” (NAJMANOVICH, 1995, p. 71).
} 
Este trabalho foi realizado para contribuir para um uso mais adequado da linguagem. Não é porque objetos estão relacionados que devemos usar um pelo outro. Inclui-se a consciência de que as expressões formatam o pensamento humano.

Intencionalidade, colaboração, laços são palavras que nos ajudaram a distinguir as expressões redes e comunidades virtuais de aprendizagem. Elas estão estreitamente ligadas ao que acreditamos ser a Educação, a linguagem dos vínculos, que se relaciona com seu tempo. Em nosso tempo, não podemos ignorar a existência do ciberespaço como potencializador de processos educativos baseados no diálogo e na construção coletiva.

Por isso, gostaríamos de finalizar este trabalho com a imagem do universo como rede e os indivíduos como nós, colaborando e aprendendo juntos. Nesta investigação, partimos de um recorte construtivo e "otimista" - o trabalho de comunidades para ampliar a comunicação humana. Arrematamos com o mesmo sentimento, de que o ciberespaço abre novas oportunidades para que a Educação se relacione mais com o mundo, a vida e as pessoas na rede do universo. 


\section{REFERÊNCIAS}

ALENCAR, Anderson Fernandes de. A pedagogia da migração do software proprietário para o livre: uma perspectiva freiriana. 2007. 255 f. Dissertação (Mestrado em Educação) - Universidade de São Paulo, Faculdade de Educação, São Paulo, 2007.

ALLEN, C. The dunbar number as a limit to group sizes. Publicado em 10 mar. 2004. Disponível em http://www.lifewithalacrity.com/2004/03/the_dunbar_numb.html. Acesso em: 05 mar. 2005.

ARAÚJO, U. F.; PUIG, J. M.; ARANTES, V. A. (org). Educação e valores: pontos e contrapontos. São Paulo: Summus, 2007.

ARENDT, H. A condição humana. 10ª ed. Rio de Janeiro: Forense Universitária, 2005.

ARISTÓTELES. A política. São Paulo: Martins Fontes, 2000.

BAKHTIN, M. Marxismo e filosofia da linguagem. 2a. ed. São Paulo: Editora Hucitec, 1981.

BARBOSA, A. C. Abordagens educacionais baseadas em dinâmicas colaborativas on line. 2008, 316 p. Tese (Doutorado) - Universidade de São Paulo, Faculdade de Educação, São Paulo.

BAUMAN, Z. Comunidade: a busca por segurança no mundo atual. Rio de Janeiro: Jorge Zahar Editor, 2003.

BELTRÁN LLERA, J. Sociedade em rede e comunidades virtuais. In: CONGRESSO IBERO-AMERICANO EDUCAREDE: Educação, Internet e Oportunidades, 3, 2007, São Paulo, SP. Disponível em:

<http://projetos.educarede.info/iiicongresso/iiicongresso_livro.pdf> Acesso em: 30 set. 2007

BOURDIEU, P. The forms of capital. Disponível em: <http://www.pontomidia.com.br/raquel/resources/03.html>. Acesso em 15 jul. 2004.

BRUNER, J. Nova teoria de aprendizagem. Bloch: Rio de Janeiro, 1973.

CARVALHO, J. de S. Por uma cultura de colaboração. EducaRede, São Paulo, 20 ago. 2007. Disponível em:

<http://www.educarede.org.br/educa/index.cfm?pg=internet_e_cia.informatica_principal\&id_ inf_escola=759>. Acesso em: 02 mar. 2008.

A escola como centro da Internet. EducaRede, São Paulo, 25 nov. 2008a. Disponível: $\langle$ http://www.educarede.org.br/educa/index.cfm?pg=internet_e_cia.informatica_principal\&id_ inf_escola=766> Acesso em: 25 nov. 2008.

Quem é o professor online? EducaRede, São Paulo, 14 nov. 2008b. Disponível em: $<$ http://www.educarede.org.br/educa/index.cfm?pg=internet_e_cia.informatica_principal\&id_ inf_escola=764>. Acesso: em 13 nov. 2008. 
CARVALHO, J. de S. et al. Comunidades de aprendizagem: uma vivência na pósgraduação. In: CONGRESSO INTERNACIONAL ABED DE EDUCAÇÃO A DISTÂNCIA, 14, 2008, Santos, SP. Disponível em:

$<$ http://www.abed.org.br/congresso2008/tc/513200874332AM.pdf>. Acesso em: 15 nov. 2008 .

CASTELLS, M. A sociedade em rede. In: e cultura. São Paulo: Paz e Terra, 1999, v. 1. A era da informação: economia, sociedade

A Galáxia da internet: reflexões sobre a Internet, os negócios e a sociedade. Rio de Janeiro: Jorge Zahar Ed., 2003.

COLE, J. et al. Surveying the digital future. Dsiponível em: <http://www.ccp.ucla.edu/uclainternet.pdf.> Acesso em: 20 mai. 2002.

CORD, B. Internet et pédagogie - état des lieux, 2000. Disponível em:

<http://wwwadm.admp6.jussieu.fr/fp/uaginternetetp/travail_collaboratif.htm>. Acesso: em 04 set. 2000 .

COSTA, C. I. Glossário. In: LÉVY, Pierre. Cibercultura. São Paulo: Editora 34, 1999.

COSTA, R. da. On a new community concept: social networks, personal communities, collective intelligence. Interface - Comunic., Saúde, Educ., v.9, n.17, p.235-48, mar/ago 2005. Disponível em <http://www.scielo.br/pdf/icse/v9n17/v9n17a03.pdf>. Acesso em: 29 fev. 2008

DEGENNE, A.; FORSÉ, M. Introducing social networks. London: Sage, 1999.

DEWEY, J. Experiência e educação. $3^{a}$. ed. São Paulo: Companhia Editora Nacional, 1979.

DILLENBOURG, P., BAKER, M., BLAYE, A.; O'MALLEY, C. The evolution of research on collaborative learning. In: E. Spada \& P. Reiman (Eds) Learning in Humans and Machine: Towards an interdisciplinary learning science. (Pp. 189-211). Oxford: Elsevier, 1996. Disponível em: <http://tecfa.unige.ch/tecfa/publicat/dil-papers-2/Dil.7.1.10.pdf〉. Acesso em: $06 \mathrm{dez} 2007$.

FRANCO, M. A. do R. S. Pedagogia como ciência da educação. Campinas, SP: Papirus, 2003.

FERREIRA, F. Teoria social da comunidade. São Paulo: Ed. Herder, 1968.

FREIRE, P. A máquina está a serviço de quem? Revista BITS, [S.1.], p. 6, maio 1984.

. Extensão ou comunicação? Rio de Janeiro: Paz e Terra, 1969.

Pedagogia da autonomia: saberes necessários à prática educativa. São Paulo: Paz e Terra, 1996.

Pedagogia do oprimido. Rio de Janeiro: Paz e Terra, 2005. 
FILATRO, A. Design instrucional contextualizado: educação e tecnologia. $2^{\mathrm{a}}$. ed. São Paulo: Editora SENAC São Paulo, 2007.

FOUCAULT, M. Vigiar e punir. Petrópolis: Vozes, 2004.

GADOTTI, M. Perspectivas atuais da educação. Porto Alegre: Artes Médicas, 2000.

GALliANO, A. G. Introdução à Sociologia. São Paulo: Harper e Row do Brasil, 1981.

GHEDIN, E.; FRANCO, M. A. do R. S. Questões de método na construção da pesquisa em Educação. São Paulo: Cortez, 2008. (Coleção docência em formação. Série saberes pedagógicos /coordenação Antonio Joaquim Severino, Selma Garrido Pimenta).

GRANOVETTER, M. The strength of weak ties. In: THE AMERICAN JOURNAL OF SOCIOLOGY, Vol. 78, No. 6, Maio de 1973. pp 1360-1380.

GUTIERREZ, S. S. Mapeando caminhos de autoria e autonomia: a inserção das tecnologias educacionais informatizadas no trabalho de educadores que cooperam em comunidades de pesquisadores. 2004, 233 p. Dissertação (Mestrado) - Universidade Federal do Rio Grande do Sul, Faculdade de Educação, Porto Alegre.

HAKKARAINEN, K. Communities of networked expertise. Oxford: Elsevier, 2004.

HARASIN, L. et al. Redes de aprendizagem: um guia para o ensino e aprendizagem online. São Paulo: Editora Senac São Paulo, 2005.

HOBSBAWN, E. A era dos extremos: o breve século XX. São Paulo: Companhia das Letras, 1995.

HOUAISS, A. Dicionário eletrônico da Língua Portuguesa. São Paulo: Objetiva, 2002.

IDÉIAS DO FILÓSOFO DO CIBERESPAÇO. EducaRede, São Paulo, 22 nov. 2007.

Disponível em:

$<$ http://www.educarede.org.br/educa/index.cfm?pg=revista_educarede.especiais\&id_especial $=280>$. Acesso em: 13 fev. 2008.

ILLERIS, K. The three dimensions of learning. Malabar (Florida): Krieger Publishing Company, 2002.

JAEGER, W. Paideia. São Paulo: Martins Fontes, 2001.

JOHNSON, S. Use the blog, Luke. Revista Salon, 10 maio 2002. Disponível em <http://www.salon.com/tech/feature/2002/05/10/blogbrain/>. Acesso em: 15 maio 2002.

JONES, S. Cybersociety. Thousand Oaks, Calif.:Sage, 1995.

KALINA, E.; KOVADLOFF, S.. As ciladas da cidade. São Paulo: Brasiliense, 1978. 
KENSKI, V. M. Comunidades de aprendizagem, em direção a uma nova sociabilidade na educação. Revista de Educação e Informática "Acesso" SEED/SP, nº 15, dez. 2001.

Tecnologias e Ensino Presencial e a distância. Campinas, SP: Papirus, 2003.

KERCKHOVE, D. de. A Pele da Cultura. Lisboa: Relógio d’ Água, 1997.

LA TAILLE, Y. de. O lugar da interação social na concepção de Jean Piaget. In: OLIVEIRA, M. K.; DANTAS, H. Piaget, Vygostky, Wallon: teorias psicognéticas em discussão. São Paulo: Summus, 1992.

LAKATOS, E. M.; MARCONI, M. A. Sociologia geral. São Paulo: Atlas, 1999.

LÉVY, P. A inteligência coletiva: por uma antropologia do ciberespaço. São Paulo: Loyola, 1998.

As tecnologias da inteligência: o futuro do pensamento na era da informática. Rio de Janeiro: Editora 34, 1993.

. Cibercultura. São Paulo: Editora 34, 1999.

LITWIN, E. Educação a distância: temas para o debate de uma nova agenda educativa. Porto Alegre: Artmed, 2001.

MACHADO, N. J. Conhecimento e valor. São Paulo: Moderna, 2004.

Educação: projetos e valores. São Paulo: Escrituras Editora, 2000. (Coleção Ensaios Transversais, 5)

. Educação e autoridade: responsabilidades, limites, tolerância. Petrópolis, RJ: Vozes, 2008.

. Epistemologia e didática: as concepções de conhecimento e inteligência e a prática docente. $6^{a}$. ed. São Paulo: Cortez, 2005.

Educação: competência e qualidade. São Paulo: Escrituras, 2009. (Coleção Ensaios Transversais, 37)

MARCONI, M. A.; LAKATOS, E. M. Técnicas de pesquisa: planejamento e execução de pesquisas, amostragens e técnicas de pesquisas, elaboração e interpretação de dados. São Paulo: Atlas, 1996.

MARTELETO, R. M. Análise de redes sociais: aplicação no estudo de transferência da informação. Ciência da Informação, v.30 n.1 Brasília jan./abr. 2001. Disponível em: $<$ http://www.scielo.br/scielo.php?script=sci_arttext\&pid=S0100-

$19652001000100009 \& \operatorname{lng}=$ pt\&nrm=iso $>$. Acesso em: 18 out. 2008.

MATURANA, H; VARELA, F. A árvore do conhecimento. São Paulo: Palas Athena, 2001. 
MINISTÉRIO DA EDUCAÇÃO. Relatório final da Comissão Assessora para Educação Superior a Distância, Portaria Ministerial 355/2002, Brasília, Secretaria de Educação Superior, disponível em: <http://www.rau-tu.unicamp.br/nou-rau/ead/document/?code=21>. Acesso em: 08 jul. 2008.

MORAN, J. M. Tendências da educação online no Brasil. Disponível em: <http://www.eca.usp.br/prof/moran/tendencias.htm>. Acesso em: 20 set. 2008.

MORENO et al. Conhecimento e mudança: os modelos organizadores na construção do conhecimento. São Paulo: Moderna, 1999.

MORIN, E. Introdução ao pensamento complexo. Porto Alegre: Sulina, 2006.

MULTIGNER, G. Sociedad interactiva o sociedad programada? In: Apuntes de la sociedad interactiva: autopistas inteligentes y negocios multimidea. FUNDESCO (org.). Cuenca (Espanha): UIMP, 1994.

MUSSO, P. A Filosofia da rede. In: PARENTE, A. (org.) Tramas da Rede: novas dimensões filosóficas, estéticas e políticas de comunicação. Porto Alegre: Sulina, 2004.

NAJMANOVICH, D. El lenguaje de los vínculos. De la independencia absoluta a la autonomia relativa. In: DABAS, E.; NAJMANOVICH, D. (orgs.). Redes. El lenguaje de los vínculos. Argentina: Editorial Paidós, 1995.

NETTO, A. Criador da web critica a própria invenção. O Estado de S. Paulo, São Paulo, 29 set. 2007. Disponível em: <http://txt.estado.com.br/editorias/2007/09/29/eco1.93.4.20070929.30.1.xml> Acesso em: 29 set. 2007.

NEWSTETTER, W.I. Teaching community organization in school of social work. NACIONAL CONFERENCE OF SOCIAL WORK, 1941.

PALACIOS, M. Cotidiano e sociabilidade no cyberespaço: apontamentos para Discussão. Disponível em: <http://facom/ufba/br/pesq/cyber/palacios/cotidiano.html>. Acesso em: 10 mai. 2007.

PALLOFF, R.; PRATT, K. Construindo comunidades de aprendizagem no ciberespaço. Porto Alegre: Artmed, 2002.

PANITZ, T. A definition of collaborative vs cooperative learning. In: The deliberations website, London Guidhall University, 1996. Disponível em:

<http://www.city.londonmet.ac.uk/deliberations/collab.learning/panitz2.html>. Acesso em: 06 dez. 2007.

PARSONS, T. Sociedades: perspectivas evolutivas e comparativas. São Paulo: Livraria Pioneira Editora, 1969.

PASSARELLI, B. Interfaces digitais na educação: alucinações consentidas. São Paulo: Escola do Futuro da USP, 2007. 
PIAGET, J. Biologia e conhecimento: ensaio sobre as relações entre as regelações orgânicas e os processos cognoscitivos. Petrópolis, Vozes, 1973.

Études sociologiques. Genebra-Paris, Droz, 1977.

POSTMAN, N. Tecnopólio: a rendição da cultura a tecnologia. São Paulo: Nobel, 1994.

PRETTO, N. de L.; ASSIS, A. Cultura digital e educação: redes já! In: PRETTO, N. de L.; SILVEIRA, S. A. da (orgs.). Além das redes de colaboração: Internet, diversidade cultural e tecnologias do poder. Salvador: EDUFBA, 2008. Disponível em: $<$ http://rn.softwarelivre.org/alemdasredes/wp-

content/uploads/2008/08/livroalemdasredes.pdf>. Acesso em: 04 fev. 2009.

PRETTO, N. de L. Desafios da educação na sociedade do conhecimento. In: CONGRESSO IBERO-AMERICANO EDUCAREDE: Educação, Internet e Oportunidades, 3, 2007, São Paulo, SP. Disponível em:

$<$ http://educarede.info/projetos.educarede.info/iiicongresso/iiicongresso_livro.pdf $>$. Acesso em: 10 set. 2008.

PRIMO, A. Interação mediada por computador: a comunicação e a educação a distância segundo uma perspectiva sistêmico-relacional, 2003. Tese (Programa de Pós-Graduação em Informática na Educação) - Universidade Federal do Rio Grande do Sul.

PUTNAM, R. D. Bowling alone: the collapse and revival of american community. New York: Simon e Schuster, 2000.

RECUERO, R. Comunidades virtuais em redes sociais na Internet: uma proposta de estudo. E-Compós, Internet, v. 4, n. Dez 2005. Disponível em: <http://www6.ufrgs.br/limc/PDFs/com_virtuais.pdf>. Acesso em: 20 jun. 2008

Comunidades virtuais: uma abordagem teórica. Trabalho apresentado no V Seminário Internacional de Comunicação, no GT de Comunicação e Tecnologia das Mídias, promovido pela PUC/RS, Porto Alegre, 2001. Disponível em: <http://pontomidia.com.br/raquel/teorica.htm>. Acesso em 10 jun. 2008.

RHEINGOLD, H. A comunidade virtual. Lisboa: Gradiva, 1996.

RIEL, M.; POLIN, L. Online Learning Communities: Common Ground and Critical Differences in Designing Technical Environments. In S. A. Barab; R. Kling; J. H. Gray (eds.). Designing virtual communities in the service of learning. New York: Cambridge University Press, pp. 16-50, 2004.

RIOS, J. A. A educação dos grupos. Rio de Janeiro. SNES e SPES do Ministério da Saúde, 1954.

RODRÍGUEZ ILLERA, J. L. Conferência: como as comunidades virtuais de prática e de aprendizagem podem transformar a nossa concepção de educação. Sísifo. Revista de Ciências da Educação, Lisboa, n. 3, mai / ago 07, p. 117-124. Disponível em <http://sisifo.fpce.ul.pt/pdfs/sisifo03PTConf.pdf> Acesso em 26 set. 2007. 
ROSENTHIEL, P. Rede. In: Enciclopédia Einaudi, vol. 13, Lógica-Combinatória. Porto: Imprensa Nacional / Casa da Moeda: 1998.

SANTAELLA, L. Navegar no ciberespaço: o perfil cognitivo do leitor imersivo. São Paulo: Paulus, 2007.

SANTOS, B. de S. Para um novo senso comum: a ciência, o direito e a política na transição paradigmática. In _. A crítica da razão indolente: contra o desperdício da experiência. $2^{a}$. ed., São Paulo, Cortez 2000, vol. 1.

Pela mão de Alice: o social e o político na pós-modernidade. 11 ed. São Paulo: Cortez, 2006.

Um discurso sobre as Ciências. 2a . ed., São Paulo: Cortez, 2004.

SCHWARTZ, G. Educar para a Emancipação Digital. In: CIVITA, R.; SANTOS, J. (Org.). Reescrevendo a Educação. 1 ed. S. Paulo: Ática, Scipione, 2007, v. 1.

SELLTIZ, C. et al. Métodos de pesquisa nas relações sociais. São Paulo: Helder, 1965.

SILVA, B. Ecologias da comunicação e contextos educacionais. Educação e cultura contemporânea, v. 2, n. 3 jan/jun 2005, p. 31-51. Disponível em <http://www.iep.uminho.pt/tceI/Material/Ecol.\%20da\%20com.\%20e\%20contextos\%20educa cionais.pdf>. Acesso: em 21 set. 2007

SILVA, M. Sala de aula interativa. Rio de Janeiro: Quartet, 2000.

SIMSON, O. R. M. von; PARK, M. B.; FERNANDES, R. S. Educação não-formal: um conceito em movimento. In: et al. Visões singulares, conversas plurais. São Paulo: Itaú Cultural, 2007, v. 3.

SOUZA, M. L. Desenvolvimento de comunidade e participação. São Paulo: Cortez, 1987.

STROGATZ, S. Sync. The emerging science of spontaneous order. New York: Theia, 2003.

TINLAND, F. l'homme aleatoire. Paris: Press Universitaires, 1997.

TIRABOSCHI, J. Do_mal.com. Galileu, São Paulo: ed. Globo, nº. 201, p. 40-49, abr. 2008.

VALENTE, J. A. Curso de Especialização em Desenvolvimento de Projetos Pedagógicos com o Uso das Novas Tecnologias: Descrição e Fundamentos. In: ; PRADO, M. E. B. B.; ALMEIDA, M. E. B. de (orgs.). Educação a distância via Internet. São Paulo, Avercamp, 2003.

VIEIRA PINTO, A. Em face da "era tecnológica". In. de Janeiro: Contraponto, 2005. Cap.1, p. 29-61. $O$ conceito de tecnologia. Rio

WATZLAVICK, P.; BEAVIN, J.; JACKSON, D. Pragmática da comunicação humana. São Paulo: Cultrix, 2000. 11ª . edição. 
WELLMAN, B.; BERKOWITZ S. Social structures: a network approach. Cambridge: Cambridge University Press, 1988.

WELLMAN et al. Does the Internet increase, ignore, decrease or replace contact with friends and relatives? The evidence from the National Geographic Web Survey. FISRT CONFERECENCE OF THE ASSOCIATION OF INTERNET RESEACHERS, Lawrence, University of Kansas, 14-17 set. 2000.

WENGER, E. Communities of practice. learning, meaning and identity. Cambridge: Cambridge University Press, 1998. 


\section{APÊNDICE A - Mensagens da rede de aprendizagem "POIEs do Butantã" trocadas por meio da ferramenta Blog em junho de 2008}

Para entender a tabela:

$\Rightarrow$ Em negrito, as mensagens publicadas pelos participantes;

$\Rightarrow$ Em itálico, os comentários às mensagens;

$\Rightarrow$ A sigla INFO indica as postagens classificadas apenas como Informação.;

$\Rightarrow$ A sigla PC indica as mensagens e comentários que expressam Pedido de Colaboração;

$\Rightarrow$ A sigla COL indica as mensagens e comentários que Colaboram explicitamente.

\begin{tabular}{|c|c|c|c|c|}
\hline & MENSAGENS / COMENTÁRI OS & I NFO & PC & COL \\
\hline 1 & $\begin{array}{l}\text { Notícias.. } \\
\text { Postada por Pa em } 27 / 06 / 2008 \text { às } 11: 29 \mathrm{~h} \\
\text { Nesse final de semestre andei meio sumida. Ainda não postei a atividade do } \\
\text { caderno pois o cd está com a coordenadora. Acho que hoje a tarde consigo } \\
\text { postá-la. Aproveito a mensagem para pedir sugestões. Vocês conhecem } \\
\text { algum site bacana de cruzadinhas online? Conheço alguns infantis bons, } \\
\text { mas eu queria um para trabalhar com a EJ A. Aquele do Coquetel tem umas } \\
\text { cruzadinhas muito difíceis, nem eu consigo resolver. } \\
\text { Beijos para todas e todos, }\end{array}$ & & 1 & \\
\hline 2 & $\begin{array}{r}\text { Endereço do multiply } \\
01 / 07 / 2008-\mathrm{Cl}: \\
\text { Olá Pa } \\
\text { A El pediu pra te mandar o endereço do Multiply. O do Álvaro é: } \\
\text { alvarosilvabraga.multiply.com } \\
\text { bjs Cl }\end{array}$ & & & 1 \\
\hline 3 & 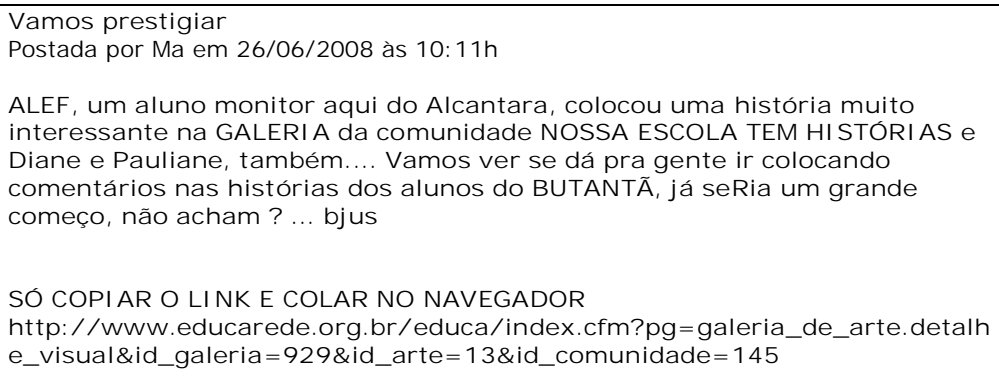 & & 1 & \\
\hline 4 & $\begin{array}{r}26 / 06 / 2008-\mathrm{Ma}: \\
\text { Obrigada } \mathrm{Na}\end{array}$ & 1 & & \\
\hline 5 & $\begin{array}{r}\text { Link } \\
\text { Ponha o link, para que nós achemos fácil. }\end{array}$ & & & 1 \\
\hline 6 & $\begin{array}{l}\text { Portaria } \\
\text { Postada por El em } 25 / 06 / 2008 \text { às } 12: 52 \mathrm{~h} \\
\text { POI Es } \\
\text { Coloquei em nosso grupo a portaria na íntegra. Leiam com atenção, caso } \\
\text { tenha alguém que não atende nem esta nem a portaria anterior deverá se } \\
\text { adaptar. } \\
\text { Abraços }\end{array}$ & & & $\mathbf{1}$ \\
\hline
\end{tabular}




\begin{tabular}{|c|c|c|c|}
\hline 7 & $\begin{array}{r}\text { Como seria diferente!!!! } \\
27 / 06 / 2008-\mathrm{El}: \\
\text { Ma } \\
\text { E como seria diferente... é uma pena que sempre depende de quem não tem a } \\
\text { menor idéia de laboratório de informática. } \\
\text { Beijos }\end{array}$ & 1 & \\
\hline 8 & $\begin{array}{r}\text { Li tudinho } \\
26 / 06 / 2008 \text { - Ma } \\
\text { Não mudou nada daquilo que nos disse na última reunião, pena que quem tem até } \\
33 \text { salas ficará sobrecarregado... Seria tão bom dobrar para ajustar as } 20 \text { aulas, os } \\
\text { alunos sairiam ganhando com isto. Se dependesse de nós né, El??? Abraço }\end{array}$ & 1 & \\
\hline 9 & $\begin{array}{l}\text { nova portaria.. } \\
\text { Postada por Anl em } 25 / 06 / 2008 \text { às } 10: 19 \mathrm{~h} \\
\text { Ontem fui a reunião de representantes do SI NPEEm e soube que saiu a nova } \\
\text { portaria dos POI Es!! } \\
\text { Beijos }\end{array}$ & 1 & \\
\hline 10 & $\begin{array}{l}\text { ótima planilha } \\
\text { Postada por } \mathrm{Cl} \text { em } 21 / 06 / 2008 \text { às } 18: 47 \mathrm{~h} \\
\text { Olá An } \\
\text { Achei ótima a sua planilha para o 2o semestre. Vou adotá-la } \\
\text { Obrigada }\end{array}$ & 1 & \\
\hline 11 & $\begin{array}{r}\text { Sugestão } \\
21 / 06 / 2008-\text { An: } \\
\text { que bom que você gostou. } \\
\text { Sugiro que use a opção "congelar painéis" (que fica em "J anela") para manter os } \\
\text { nomes dos alunos sempre visíveis. }\end{array}$ & & 1 \\
\hline 12 & $\begin{array}{l}\text { MEC lança portal para professor } \\
\text { Postada por An em } 19 / 06 / 2008 \text { às } 00: 01 \mathrm{~h} \\
\text { Notícia veiculada pelo J ornal Atribuna de Santos: } \\
\text { O Ministério da Educação (MEC) lançou nesta quarta-feira o Portal do } \\
\text { Professor, um site voltado para os docentes buscarem elementos para as } \\
\text { aulas e para sua formação. A idéia, segundo o MEC, é inserir os professores, } \\
\text { principalmente os que estão longe dos grandes centros, no ambiente das } \\
\text { novas tecnologias. O endereço do site é } \\
\text { http:/ / portaldoprofessor.mec.gov.br. } \\
\text { O site faz parte da política de informatização das escolas que, segundo o } \\
\text { governo federal, prevê a instalação de } 25 \text { mil laboratórios de informática, } \\
22 \text { mil escolas com banda larga e capacitação de cem mil professores ainda } \\
\text { este ano. } \\
\text { Ele terá sugestões de aulas de acordo com o currículo de cada disciplina e } \\
\text { recursos como vídeos, fotos, mapas, áudio e textos para serem usados em } \\
\text { sala de aula. } \\
\text { “No ambiente virtual, o professor não será passivo. Ele vai construir seu } \\
\text { plano de aula, pesquisar, trocar práticas pedagógicas com colegas, vai ter } \\
\text { um mundo aberto à sua frente”, afirmou o ministro da Educação, Fernando } \\
\text { Haddad, nessa quarta-feira. } \\
\text { Outros recursos } \\
\text { A proposta do site é oferecer chats, blogs, seminários on-line e links de } \\
\text { bibliotecas digitais e museus. As iniciativas dos profissionais de ensino do } \\
\text { país serão apresentadas no “J ornal do Professor”, com textos e vídeos } \\
\text { experimentais. } \\
\text { Também foi lançado o Banco I nternacional de Objetos Educacionais, que } \\
\text { permite acesso a vídeos, animações, jogos, textos, áudios e softwares } \\
\text { educacionais. No banco, professores terão acesso a conteúdos produzidos } \\
\text { por países como Argentina, Canadá, China, Alemanha, França, I tália, } \\
\text { Holanda, Portugal, Reino Unido e Estados Unidos. O endereço na I nternet é } \\
\text { o http:/ / objetoseducacionais.mec.gov.br. As informações são do G1, da } \\
\text { Globo. }\end{array}$ & & $\mathbf{1}$ \\
\hline 13 & $\begin{array}{r}\text { Boa dica } \\
20 / 06 / 2008 \text { - Ma } \\
\text { Dei uma espiadinha no site do MEC e verifiquei alguns links de atividades, gostei } \\
\text { bastante... Boa dica!!! }\end{array}$ & 1 & \\
\hline
\end{tabular}




\begin{tabular}{|c|c|c|c|c|}
\hline 14 & $\begin{array}{r}\text { É } \\
\text { É uma boa dica, entrei nos dois portais, aqui na DRE não consegui baixar os vídeos, } \\
\text { mas achei interessante. No http:// objetoseducacionais.mec.gov.br é preciso se } \\
\text { cadastrar, mas me pareceu muito legal, bom recurso. }\end{array}$ & & & 1 \\
\hline 15 & $\begin{array}{l}\text { Água } \\
\text { Postada por An em 17/06/2008 às } 20: 12 \mathrm{~h} \\
\text { Essa apresentação: } \\
\text { http:// br.youtube.com/ watch?v=kcggwL2p2_o } \\
\text { Eu fiz a pedido de uma professora da EJ A. Ela desce com sua sala ao } \\
\text { laboratório e utilizamos essa apresentação para que os alunos exercitassem } \\
\text { a leitura e cantassem juntos. Esse tema ela já vinha desenvolvendo em sala } \\
\text { de aula e depois, os aluno escreveram sobre o tema no Word. } \\
\text { Esse tipo de apresentação vale apena ser colocada na arquivoteca? } \\
\text { PS: No caso, colocaria apenas o link, haja visto, o tamanho do arquivo } \\
\text { exceder o limite do site. }\end{array}$ & 1 & & \\
\hline 16 & $\begin{array}{r}\text { Muito boa!!! } \\
21 / 06 / 2008-\mathrm{Cl} \\
\text { Olá An } \\
\text { Posso ouvir esta música milhões de vezes e mesmo assim não enjôo. O Guilherme } \\
\text { fez um verdadeiro tributo a água. As imagens que você escolheu foram perfeitas, a } \\
\text { apresentação está muito bonita!! Vou indicar para meus alunos. Parabéns!!!Bjs Cl }\end{array}$ & 1 & & \\
\hline 17 & $\begin{array}{r}\text { Legal essa apresentação } \\
20 / 06 / 2008 \text { - Mo }\end{array}$ & & & 1 \\
\hline 18 & $\begin{array}{l}\text { BOM FINAL DE SEMANA } \\
\text { Postada por Gu em } 13 / 06 / 2008 \text { às } 18: 50 \mathrm{~h} \\
\text { Colegas postei hoje na arquivoteca um desenho de uma aluna sobre a festa } \\
\text { junina do Mange que será realizada amanhã } 14 / 06 / 08 \text {, achei interessante o } \\
\text { detalhe da maça do amor em cima da mesa, esta menina é da 2a série ciclo } \\
\text { I e só tem } 7 \text { anos. } \\
\text { Desculpem mas babo mesmo. } \\
\text { Beijos }\end{array}$ & 1 & & \\
\hline 18 & $\begin{array}{r}\text { Realmente } \\
17 / 06 / 2008-\mathrm{An} \\
\text { Um ótimo desenho para quem tem apenas sete anos. }\end{array}$ & 1 & & \\
\hline 20 & $\begin{array}{l}\text { Multiply } \\
\text { Postada por El em 13/06/2008 às } 17: 20 \mathrm{~h} \\
\text { Não esqueçam de mandar para a Pa os endereços dos multiplys, blogs e } \\
\text { demais recursos que usamos para ela divulgar no multiply do EDUCOM da } \\
\text { nossa DRE. } \\
\text { Abraço }\end{array}$ & & 1 & \\
\hline 21 & $\begin{array}{r}\text { Blog } \\
\text { 17/06/2008 - Ma } \\
\text { El o blog é http://www. blogdoalcantara. blogspot.com/ } \\
\text { e o multiply é http://mritapsil.multiply.com/ } \\
\text { >>> mas nunca consigo abrir o multiply nos computadores da escola ... } \\
\text { Abraços }\end{array}$ & & & 1 \\
\hline 22 & $\begin{array}{r}\text { Por onde? } \\
17 / 06 / 2008 \text { - An } \\
\text { É para mandar para um e-mail dela? Qual é o endereço dela? }\end{array}$ & & 1 & \\
\hline 23 & & & & \\
\hline
\end{tabular}




\begin{tabular}{|c|c|c|c|c|}
\hline & $\begin{array}{l}\text { Registro do An } \\
\text { Postada por El em } 13 / 06 / 2008 \text { às } 17: 18 \mathrm{~h} \\
\text { An } \\
\text { Será que você poderia disponibilizar a planilha de presença no Material de } \\
\text { Estudo, assim que quiser fazer uso ficaria a vontade. } \\
\text { Abraços }\end{array}$ & & 1 & \\
\hline 24 & $\begin{array}{r}\text { Novo modelo } \\
19 / 06 / 2008-\mathrm{Na} \\
\text { Fiz um outro modelo já pensando no segundo semestre e postei na "Arquivoteca". }\end{array}$ & & & 1 \\
\hline 25 & $\begin{array}{r}\text { Como? } \\
\text { Eu não vi nenhum link, ou botão, para inclusão de arquivos no "Material de Estudo". } \\
\text { Acho que só você pode fazer isso, El. } \\
\text { Vou postar o arquivo na "Arquivoteca". }\end{array}$ & & 1 & \\
\hline 26 & $\begin{array}{l}\text { Material } \\
\text { Postado em 13/6/2008 por Ela } \\
\text { Vamos combinar: os textos que servem de apoio para o nosso trabalho } \\
\text { tanto na escola, quanto nas comunidades (para quem já tem comunidade da } \\
\text { escola) postaremos no Material de Estudo. Já os produtos finais podem ser } \\
\text { postados no arquivoteca. } \\
\text { Abraços }\end{array}$ & & 1 & \\
\hline 27 & $\begin{array}{l}\text { Fórum } \\
\text { Postada por El em 13/6/2008 às 16:55 } \\
\text { Tem novo tema no Fórum postei dois textos no Material de Estudo para dar } \\
\text { base nas nossas discussões - "Recursos aos meios oferecidos pela } \\
\text { sociedade da informação" e "Participação democrática" do livro Educação } \\
\text { um tesouro a descobrir de J acques Delors. }\end{array}$ & 1 & & \\
\hline 28 & $\begin{array}{l}\text { Horário 4âaira } \\
\text { Jo às } 10: 04 \text { em } 13 / 6 / 2008 \\
\text { El talvez aqui não seja o local ideal para o assunto mas acho que anotei } \\
\text { horário errado da 4a feira. } \\
\text { Segue o correto } \\
\text { 1a2ae3a aula individual } \\
\text { 4a Projeto SAAI } \\
5 \text { a Nossa Escola Tem História } \\
\text { 6a Pesquisa } \\
\text { Por favor verifique }\end{array}$ & & & 1 \\
\hline 29 & $\begin{array}{l}\text { Multiply do Alcântara } \\
\text { Ma às } 23: 12 \text { em } 12 / 6 / 2008 \\
\text { Nosso multiply (meu e da A.) ainda é um bebê, a intenção é publicar as } \\
\text { produções dos alunos suas memórias. Gostaria que vcs, amigos e amigas, } \\
\text { nos adicionassem e quando possível deixarem comentários nas histórias } \\
\text { deles a título de estímulo. Farei o mesmo!!! Abraços } \\
\text { http:/ / mritapsil.multiply.com/ }\end{array}$ & & 1 & \\
\hline 30 & $\begin{array}{l}\text { Multiply do Brasil-J apão } \\
\text { Postada por Cr em 11/06/2008 às } 16: 12 \mathrm{~h} \\
\text { Mandei convites para o multiply do BJ a todos do grupo, se alguém não } \\
\text { recebeu o convite me mande um e-mail que eu reenvio. As fotos estão } \\
\text { muito boas, em breve haverá uma "biografia" do EDUCOM. Aguardem. }\end{array}$ & & & 1 \\
\hline 31 & $\begin{array}{r}\text { Endereço } \\
16 / 06 / 2008-\mathrm{El} \\
\text { Cr coloque o endereço do multiply no blog } \\
\text { beijos }\end{array}$ & & 1 & \\
\hline 32 & $\begin{array}{r}\text { Muito legal! } \\
13 / 06 / 2008-\mathrm{Jo} \\
\mathrm{Cr} \\
\text { Parabens, a você e aos seus alunos o trabalho está muito legal.É gratificante ver o } \\
\text { projeto dando certo. }\end{array}$ & 1 & & \\
\hline
\end{tabular}




\begin{tabular}{|c|c|c|c|c|}
\hline 33 & $\begin{array}{r}\text { Resp } \\
\text { Olá Cr não recebi seu convite, deixo aqui o endereço do meu } \\
\text { multiply }>>>\text { http://mritapsil.multiply.com/ }\end{array}$ & & & 1 \\
\hline 34 & $\begin{array}{r}\text { fotos } \\
12 / 06 / 2008-\mathrm{El} \\
\mathrm{Cr} \\
\text { Eu recebi, as fotos estão bem legais, dê meus parabéns para os alunos do EDUCOM. }\end{array}$ & 1 & & \\
\hline 35 & $\begin{array}{l}\text { Caderno de Orientações Didáticas - Planilha eletrônica } \\
\text { Postada por An em 10/06/2008 às } 20: 33 \mathrm{~h} \\
\text { Postei dois arquivos com planilhas eletrônicas feitas pelos alunos. } \\
\text { Esqueci de dizer que as atividades do EDUCOM que postei tam bém são } \\
\text { inspiradas no caderno de orientações didáticas, onde usamos audacity. }\end{array}$ & & & $\mathbf{1}$ \\
\hline 36 & $\begin{array}{r}12 / 06 / 2008 \text { - An } \\
\text { As duas gravações sobre o dia das mães (atividade pelo EDUCOM), estão também } \\
\text { na ARQUIVOTECA. }\end{array}$ & & & $\mathbf{1}$ \\
\hline 37 & $\begin{array}{r}\text { Planilhas } \\
12 / 06 / 2008-\mathrm{El} \\
\text { An } \\
\text { Onde você postou? Vamos mandar para a Pa colocar no Multiply do EDUCOM. } \\
\text { Lembra combinamos. }\end{array}$ & 1 & & \\
\hline 38 & $\begin{array}{l}\text { SANTO POIE André } \\
\text { Postada por Jo em 10/06/2008 às } 16: 22 \mathrm{~h} \\
\text { É An fui obrigada te santificar,eu lá lembrava do tracinho? } \\
\text { claro que depois da ajuda do An eu consegui acessar o forum, menos mal } \\
\text { um problema a menos para El }\end{array}$ & 1 & & \\
\hline 39 & $\begin{array}{r}\text { Que nada } \\
11 / 06 / 2008-\text { An: } \\
\text { Estamos aí para se ajudar. } \\
\text { Engraçado, como parece que conversamos mais aqui do que na escola ehehehehe. }\end{array}$ & 1 & & \\
\hline 40 & $\begin{array}{l}\text { PARA POIE TA } \\
\text { Postada por Gu em } 06 / 06 / 2008 \text { às } 08: 21 \mathrm{~h} \\
\text { Olá Ta como posso fazer para te mandar o CD? } \\
\text { Se você quiser passar aqui no Mange também tudo bem, se não me diga um } \\
\text { jeito que eu te mando com maior prazer. } \\
\text { Beijos }\end{array}$ & & 1 & \\
\hline 41 & $\begin{array}{r}\text { Mandar o cd } \\
10 / 06 / 2008-\mathrm{Ca}: \\
\text { Posso te pedir para mandar um pela Eli? }\end{array}$ & & 1 & \\
\hline 42 & $\begin{array}{r}\text { Respondendo a Guilhermina } \\
07 / 06 / 2008-T a\end{array}$ & & & $\mathbf{1}$ \\
\hline 43 & $\begin{array}{l}\text { Pequenos e baratos, laptops ultraportáteis conquistam consumidor } \\
\text { Postada por Ga em 05/06/2008 às } 23: 23 \\
\text { Matéria sobre os laptops de baixo custo publicada na IDG }\end{array}$ & & & 1 \\
\hline 44 & $\begin{array}{l}\text { EDUCOM NO CONDE } \\
\text { Acabei de postar duas atividades de alunos participantes do projeto Educom } \\
\text { do "Conde", na "ARQUIVOTECA". } \\
\text { Trata-se de homenagem ao dia das mães, fizemos um CD com várias delas, } \\
\text { cada uma com um aluno diferente. } \\
\text { An } \\
\text { PS: Aproveito para agradecer a Ta que disponibilizou a lista de sites } \\
\text { educativos. } \\
\text { An às } 22: 41 \text { em } 5 / 6 / 2008\end{array}$ & & & $\mathbf{1}$ \\
\hline
\end{tabular}




\begin{tabular}{|c|c|c|c|c|}
\hline 45 & $\begin{array}{l}\text { Pensamento para a sexta-feira } \\
\text { Postada por An } \\
\text { "Somos o que pensamos. Tudo o que somos surge com nossos } \\
\text { pensamentos, fazemos o mundo." } \\
\text { Buda } \\
\text { Tenham uma ótima sexta-feira e um "alivioso" fim de semana. } \\
\text { An }\end{array}$ & 1 & & \\
\hline 46 & $\begin{array}{r}\begin{array}{r}\text { Pensamento positivo. } \\
09 / 06 / 2008-\mathrm{Na}\end{array} \\
\mathrm{Cl} \\
\text { Hehe, é esse o espírito da coisa. } \\
\mathrm{An}\end{array}$ & 1 & & \\
\hline 47 & $\begin{array}{r}\text { Buda } \\
06 / 06 / 2008-\mathrm{Cl} \\
\text { É An e colegas } \\
\begin{array}{r}\text { Se somos o que pensamos, precisamos pensar muito positivo, não é??? Se não fica } \\
\text { muito difícil conseguir bons resultados. } \\
\text { grande abç e bom fim de semana }\end{array} \\
\mathrm{Cl}\end{array}$ & 1 & & \\
\hline 48 & $\begin{array}{l}\text { Fórum } \\
\text { Postada por Jo em 04/06/2008 às } 11: 26 \mathrm{~h} \\
\text { El,tentei novamente e realmente não consigo acessar o fórum coloquei poie } \\
\text { não deu e poie bt também não.Vê o que pode ser feito para eu poder } \\
\text { acessar. }\end{array}$ & & 1 & \\
\hline 49 & $\begin{array}{r}\text { tracinho } \\
\text { 05/06/2008 - An } \\
\text { Colega, voce está pondo o tracinho? } \\
\text { "dre-bt"? }\end{array}$ & & & 1 \\
\hline 50 & $\begin{array}{r}\text { Corrigindo } \\
04 / 06 / 2008-\text { Ta } \\
\text { dre-bt é a senha. A senha poie é para o projeto Nossa escola tem história. Ta }\end{array}$ & & & 1 \\
\hline 51 & $\begin{array}{r}\text { Tente assim } \\
\text { 04/06/2008 - Ta } \\
\text { Jo: } \\
\text { Tente poie-bt. Ta }\end{array}$ & & & 1 \\
\hline 52 & $\begin{array}{l}\text { Registros } \\
\text { Postada por anl em } 04 / 06 / 2008 \text { às } 09: 10 \mathrm{~h} \\
\text { Aceito sugestões e idéias de como fazer um registro melhor .... } \\
\text { Como vocês costumam fazer os registros? Diariamente ? Utilizando o } \\
\text { computador?I mprimindo os trabalhos? Portifólio? Não faz.? faz pouco? } \\
\text { cEu comecei registrando os conteúdos e os procedimentos no meu } \\
\text { caderno...Pretendo melhorar..rss } \\
\text { Obrigada } \\
\text { Beijos }\end{array}$ & & 1 & \\
\hline 53 & $\begin{array}{r}\text { Obrigada!!! } \\
10 / 06 / 2008-\text { anl } \\
\text { Adorei a sua idéia Ir. !! e Obrigada pelos comentários! Me ajudaram muito!.... } \\
\text { beijos Ir, Vi,Cl,An..enfim, todos os POIES!! }\end{array}$ & 1 & & \\
\hline 54 & $\begin{array}{r}\text { Paradoxo } \\
07 / 06 / 2008-V i: \\
\text { Oi An! Oi Ir! }\end{array}$ & 1 & & \\
\hline
\end{tabular}




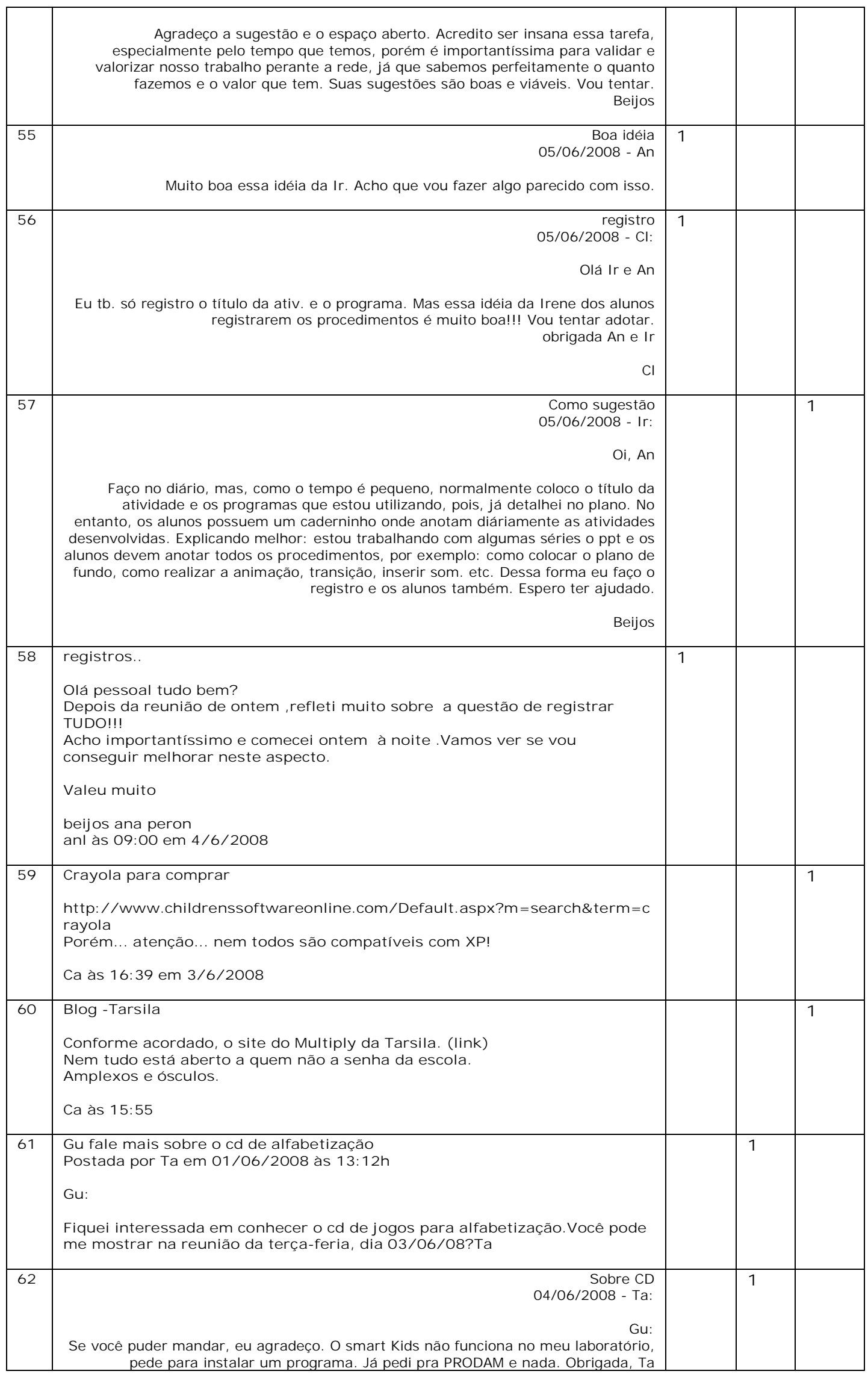




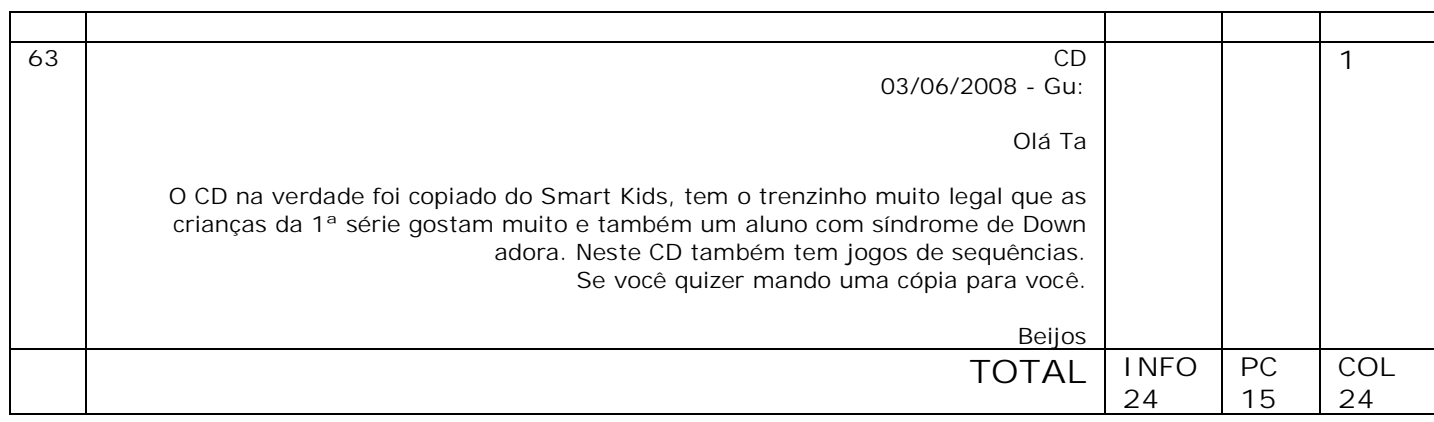




\section{APÊNDICE B - Entrevista realizada com a Prof a ${ }^{\text {. Dr }}{ }^{\text {a }}$. Vani Kenski}

\section{Como o curso foi elaborado? Havia uma proposta inicial? Quem a produziu?}

O curso, em sua versão primeira, já que todas as outras foram fiéis a ela, veio de uma necessidade sentida por mim quando fazia consultoria, quando fiz a organização do projeto de Educação a Distância da Metodista e da necessidade de seleção de ambientes virtuais. Aí a gente começa ver que cada ambiente virtual tem uma vocação, é orientado por um determinado tipo de lógica, de metodologia, de teoria de aprendizagem, que reflete muito a teoria dos seus idealizadores ou aquilo que eles pensam sobre a relação ensino e aprendizagem. Em geral, eles são técnicos, pessoas da área de exatas e a preocupação pedagógica não é tão grande, ou quase, às vezes, não é nenhuma. Então, dezenas de ambientes que eu já levantei, analisei, pesquisei, cada um deles reflete um determinado tipo de encaminhamento.

Por outro lado, quando eu estava na Unicamp, nós sentíamos a aversão que o pessoal de exatas tinha ao Teleduc porque ele, na época, era um ambiente dentro de uma proposta construcionista, de trabalho colaborativo. Então não tinham as questões de múltipla escolha, não tinha tudo aquilo que o pessoal da física, principalmente, adora e que na época queriam usar o ambiente, mas não aceitavam. Tanto que logo depois eles tiveram que desenvolver algumas funcionalidades para atender a área de exatas, que não se sentia contemplada porque não tinha, por exemplo, uma ferramenta de avaliação. E isto é um repúdio para eles porque tinha que ter uma avaliação formal, muito objetiva, com múltipla escolha, com espaços muito definidos de quem pergunta e quem responde e respostas certas e erradas.

Então todo esse processo, o fato de há muito tempo eu vir desenvolvendo projetos e oferecendo disciplinas ligadas a formação de professores para o uso das tecnologias, me deu a idéia e fez com que eu concebesse a estrutura [do curso EAV1]. Isto foi feito no ano 2000, em 2001 ela estava organizada com a mesma estrutura que ela tem hoje, com três nomes extremamente enxutos e que pudessem dar exatamente aquilo que eu gostaria de ver trabalhado dentro dos três momentos:

4) Tecnologia: para os alunos vivenciarem e se sentirem à vontade com o ambiente.

5) Ensino: onde os alunos já iam perder toda essa liberdade de experimentar e tudo mais, de se sentirem confortáveis no ambiente. Eles iam se ajustar à regra porque a própria relação de ensino e aprendizagem é uma relação mais formal, mais fechada, mais estruturada. Eles podiam fazer algumas coisas que quisessem, mas dentro de alguns parâmetros baseados em teorias de aprendizagem.

6) Projeto: a maturidade que eles foram adquirindo neste processo dava a eles a autonomia que era requerida para chegar neste terceiro momento, ganhar asas e voar, fazerem seus próprios projetos.

A idéia desde o início foi essa. Essa disciplina, na USP, quando foi pra lá oferecida, levou quase um ano para tramitação toda e em 2002 eu pude oferecer essa disciplina

\section{E o que foi em 2001?}

2001 foi a idealização dela. Ela é totalmente vinculada às minhas pesquisas. Em 2001, ela foi idealizada como disciplina e submetida aos diferentes trâmites da área, da CPG, porque ela 
vinha já com o diferencial de ser uma disciplina que tinha alguns momentos só presenciais. $\mathrm{E}$ isso era inédito.

$\mathrm{Na}$ época, na USP, nós ainda tínhamos uma versão caseira traduzida lá do WebCT, que pra mim ainda é o melhor ambiente, uma ambiente em que eu me sentia muito à vontade porque eu estudei nele. Em 1997, 98 eu fiz vários cursos colaborativos em diferentes lugares do mundo, online todos eles, que eram oferecidos por universidades diferenciadas. E o que eu fiz nos Estados Unidos foi desenvolvido quando tomei conhecimento do WebCT, em 98, acho. Foi um ambiente em que eu me adaptei tremendamente, muito interessante, gostei dele. Então, quando eu vi que tinha Webct, que era caro, muito caro, na época já era um ambiente muito caro. E que tinha uma versão gratuita dentro da USP eu me entusiasmei muito! Eu queria vivenciar e o WebCT, em termos de síntese. Ele faz o que fazem os três ambientes diferentes [Moodle, Teleduc e CoLearn] pra não conseguir chegar à metade do que eu fazia lá.

Tanto que a primeira disciplina eu usei o WebCT porque ele é dinâmico. Eu dividia a turma também em três grandes grupos. Tinha os alunos-tutores, que lideravam esses grupos porque era uma formação paralela. Ou eles eram alunos de meu grupo de pesquisa, ou eram meus orientandos. Então são pessoas que já vêm comigo discutindo... É um processo de formação paralela. Então, a construção da disciplina, a reflexão sobre ela, essa é uma formação para os alunos e para os tutores, em níveis diferenciados. E os tutores teoricamente, e na prática, já vinham lendo e discutindo no grupo de estudo. Então era uma maneira deles viabilizarem.

No WebCT, por exemplo, os alunos podem criar no ambiente a sua homepage e, na época, em 2002, eles colocavam som, imagem. Então, por exemplo, o Gerson, que era um dos tutores, eram duplas, mas o Osmar saiu e o Gerson ficou com um grupo de dez pessoas, mas ele conseguiu o processo de colaborativo com o grupo, e eles montaram a homepage deles. Era como se tivessem três cursos diferentes. A Poliane e a Vera com um [grupo], o Gerson com outro e a Adriana e a Márcia com o outro grupo. Os tutores é que definiam os grupos, e depois eles trocavam. Todas as dinâmicas [da disciplina] vieram do que vivenciei em 97 e 98 nesses cursos que eu fiz, muitas dessas dinâmicas.

\section{Como era a dinâmica entre os professores do curso para acompanhamento e proposição das atividades? Você tinha uma função específica neste processo?}

A proposição era sempre minha. A estrutura, a elaboração das atividades, a organização era minha. Havia todo um corpo de atividades montada, estabelecida, porque isso fazia parte da minha pesquisa. Então já era uma proposta, já estava definida, e sobreviveram. O que a gente via [em grupo, com os tutores] como é que os alunos estavam respondendo a esta estrutura e fazíamos alterações pontuais dentro do processo.

O processo é o de currículo espiral, do Bruner; ele tem todo o embasamento teórico voltado ao uso de uma proposta colaborativa de aprendizagem em cursos online; ela precisa ser feito a distância porque um dos grandes focos dela é mostrar que você pode fazer educação a distância de qualidade; e as interações presenciais são interações mais sociais, não tem um aspecto de aprendizado teórico, que e construído dentro das interações online. Essa é uma das propostas.

O currículo vai em espiral em diferentes movimentos: o movimento e o da prática, do processo, da vivência. Então a cada movimento existe uma integração, que vai do individual 
para o grupal, você não chama o exercício de atividade, mas de desafio. E é desafio mesmo, que vem do individual e vai construir uma proposta que não é mais o pensamento de um, mas o pensamento de todos. E aí tem Lévy [Pierre Lévy] bem envolvido no processo da construção da inteligência coletiva. E tem o Kerckhove quando ele vai falar da construção da web, daquele grupo de pessoas que estão preocupadas em aprender e construir algo juntas, que tem interesse e que seja importante para todas elas. Então, misturando todas essas bases teóricas e reflexões, a disciplina foi idealizada já em 2000/2001 e começou a ser oferecida em 2002.

Foram três versões: 2002, 2006 e 2008. A versão do WebCT foi uma versão muito interessante, deu também super certo, muito certo.

\section{Em 2006 e 2008 também usou o ambiente WebCT?}

Não porque a USP perdeu o convênio. Na época em que foi disponibilizado, pouquíssimas pessoas usaram o ambiente, muito poucas.

[Na diciplina dada] Em 2006, nós começamos com o Teleduc, depois o Col, no meio, e o Moodle ao final. Os dois ambientes [Teleduc e Moodle] hospedados no servidor da SITE [empresa da Vani], não era idéia de usar a SITE, mas é que a própria universidade não está preparada para a Educação a Distância. Porque quando nós fomos usar o Teleduc, instalado na USP, com os alunos, ele fechava para manutenção na sexta-feira e só abre na segunda. Aí, logo na primeira semana, o pessoal começou a gritar e eu disse: "Esquece. Vamos para o meu que está 24 hs no ar e não vai cair". Agora o Col não, o Col tinha que ficar na USP. E porque o Col no meio? Porque era mais restrito e mais fechado. A visão do Col é a visão de Ausubel, e nele tem a proposta bem instruída de quem é professor, de quem é aluno e qual o papel do professor e do aluno. E o papel do aluno é o de responder aquilo que o professor pergunta. Não havia interação, era um ambiente muito mais difícil.

O Teleduc é um ambiente extremamente didático, todo arrumadinho, certinho, com as suas gavetinhas, como é uma estrutura formal de ensino. Mas para quem começa ele é muito interessante. Aí quando foram para o Col, eles não agüentaram, acharam horrível, resistiram e aí eu disse que o Teleduc continuava aberto, se vocês quiserem ir para lá, vocês podem desenvolver lá. Aí começou o passa-passa, a migração. Depois veio o Moodle, que na época ainda era "cinco ponto qualquer coisa", um ambiente ainda com uma boa parte em inglês, então não era tão amigável. Mas deu para desenvolver projetos. Eu abri no Moodle na época uma disciplina para cada aluno, ou cada dupla, que iria fazer o projeto tinha lá e podia abrir e eu coloquei o como professor da disciplina. No Moodle ele tinha autonomia para ir lá, selecionar, colocar texto, brincar com o ambiente. Isso foi muito gostoso, eles se interessaram muito.

Agora voltando às questões. Eu gostaria que você falasse mais sobre a dinâmica entre você e os tutores. Antes deixa eu abrir um parênteses: lembra que na minha banca de qualificação foi recomendado, inclusive por você, de que eu deveria adorar o termo "professor" em vez de "tutor"? Como fica em relação aos tutores do curso?

Eles não eram professores, eram tutores mesmo porque não tinham nenhuma autonomia como professores. Eles não decidiam nada, pelo menos nesta versão 2008. Eles estavam começando comigo [em relação ao grupo de pesquisa]. 


\section{E qual era o papel deles?}

Era assim: no primeiro curso, em 2002, havia realmente um grupo, que já estava historicamente comigo, e tudo mais. Nesta turma de 2008, os três tutores eram recémchegados ao grupo de pesquisa, à orientação comigo, e como alunos. A Teresa e o Rodrigo, era o primeiro semestre deles matriculados. Então [a tutoria] era uma forma deles se ambientarem comigo discutirem comigo as propostas deles. Então os nossos encontros eram encontros onde eles aprendiam e aprendiam a minha maneira de atuar. Era uma maneira de você fazer uma orientação em serviço. As reuniões que nós tínhamos eram reuniões de orientação e de discussão. Mas eles não tinham um papel de definição da disciplina.

O papel deles qual era? Era um rodízio: cada semana um assumia, passava o bastão pro outro, eu criei pra eles na SITE o e-mail de tutor e assim, cada um deles entrava e assumia a tutoria. De todos, o Marcelo foi o que mais fez, que era dinamizar o fórum e, inclusive o Marcelo dizia: a minha esquizofrenia está no auge porque eu faço pergunta como Marcelo e respondo como tutor. Então era mais a dinamização dos grupos, ao qual faziam parte, para não deixar o grupo morrer.

Toda a proposta se dá em cima da participação dos alunos. Se os alunos não participam, se o grupo é murcho, aí a coisa não vai. Por isto tem os líderes, que são fundamentais e todos precisam passar por esta função de líder, que é um aprendizado, porque tem que ter toda essa movimentação de articulação, de chamar o pessoal ao trabalho e tudo mais. E o tutor, ao mesmo tempo, me relata os problemas paralelos que possam acontecer e que eu não tenho noção só pela interação e pelo ambiente, e as dificuldades que os alunos. É um bom feedback pra mim, de como anda o processo. E, ao mesmo tempo, de dinamizar o fórum. Então ele entra como tutor, você pergunta, pouquíssimas pessoas fizeram perguntas de ordem técnica. $\mathrm{E}$ quando fazem a gente repassava, ou eu mesmo repassava para o pessoal da técnica.

A figura do professor, historicamente, na cultura educacional, ela é uma figura muito marcada. Então o tutor é como se fosse um meio de campo, aquelas perguntas que você tem medo de fazer ao professor, talvez ao tutor você se abra mais. Então, era um tutor que ficou invisível, ele não estava explícito, ao contrários dos tutores de 2006 e 2002, que todos sabiam quem era, eram tutores que agiam mais nos bastidores. Mas eles não tinham nenhuma definição de ordem pedagógica, eles não eram professores.

\section{Então o tutor era um dinamizador?}

Não, ele ajudava na dinamização. Porque eu estava bastante presente. Mas não deleguei em nenhum momento essas funções. Eles só eram mais um apoio.em alguns momentos, por exemplo eu dizia "Marcelo vai lá, dá uma corrida e responde pra mim", ou então Teresa. Rodrigo era bem mais devagar, assumiu função como aluno mesmo, como tutor deixou bastante a desejar. Agora o Marcelo não, ele já tem outros tipos de atuação, ele me ajudou muito a manter. [Marcelo e Teresa são doutorandos, Rodrigo acabara de ingressar ao mestrado].

\section{O nome tutor carrega um peso na literatura de EaD...}

$\mathrm{Na}$ verdade eles eram auxiliares que fizeram alguns tipos de atuação, que vou aprofundar um pouco mais na minha nova pesquisa. Por exemplo, algumas hipóteses que eu levantei, que eu nem tinha noção de que iria acontecer, foi uma situação muito próxima da que eu vivi de que 
eu tinha um tutor, que era um tutor, eu recuperei isto, chamava Mark, e que pra mim era um só. Era a pessoa que ficava disponível para responder a dúvidas, era um apoio. Um apoio para responder dúvidas. Mas lá no curso que eu fiz em 98 e que o tutor chamava Mark, era uma pessoa extremamente solícita. Você perguntava e logo depois você já tinha a resposta. E isso assim, domingo, uma loucura...

Fora dos seus cursos, levando-se em conta os conhecimentos que você tem, o tutor é o apoiador?

Não, não. Aí são coisas diferentes, eu não posso nem comparar. É como uma amiga diz: “o modelo de tutor de curso da Vani não é o modelo regular". Então não são. Mas só pra dizer, este Mark, ao final, o professor abriu pra nós, era um grupo de quatro ou cinco alunos dele que usavam a palavra Mark, de marca mesmo. Mas cada um era uma pessoa diferente, só que quando eles estavam no papel de tutor, eram Mark. E nós não percebemos. Às vezes o Mark era mais direto, outras vezes mais carinhoso, e a gente achava que era questão de mudança de temperamento. E não era, era mudança de pessoa. E o que se passou comigo se passava com vocês também. Que a turma não levantava a identidade dele, não identificava que cada semana tinha uma pessoa diferente. E tratava a todos como se fosse alguém que não estava infiltrado na turma. Quer dizer, o nível de percepção desenvolvido no grupo no ensino online precisa ser apurado. Mesmo quando eu dizia “Teresa, fala no feminino". E a Teresa falava, dava resposta no feminino e as pessoas articulavam que nas outras semanas era no masculino.

\section{Eu tinha percebido...}

Mas não apontou.

Não, não apontei. Achei que estava ficando louca (risos)

É exatamente, vamos dizer, essa ação cultural de submissão ao professor: "o professor é aquele que está certo, sou eu que estou errada, ou tem alguma coisa que não estou percebendo" e tudo mais. Isso ficou muito claro na vivencia de vcs.

\section{Os tutores sugeriam ou mais apoiavam?}

Mais apoiavam.

\section{E você chamou de tutor porque era...}

Era um nome que já está na cultura.

\section{Poderia ser apoiador, Mark ou qualquer outro nome?}

Poderia, mas apoiador é muito feio.

\section{E por que você os chamou para ajudar?}

Pelo que estou te falando: é uma forma de aproximação, deles poderem, hoje em dia, estarem fazendo artigo [a respeito da disciplina] comigo, a pesquisa sobre a EAV comigo. Ou seja, é um grupo de pesquisa, e uma forma deles incorporarem a filosofia aos métodos e aos projetos. 


\section{Refiro-me à comunidade...}

Ah! Na comunidade, eles estavam orientados a não estarem no mesmo grupo. Cada um ia para um grupo diferente porque dava pra mim o feedback de diferenciadas perspectivas dos grupos. De, por exemplo, o grupo não está se entendendo, precisa de uma interação maior naquele grupo, a liderança não está funcionando... Eles eram meus informantes nos grupos. E aí, quando eu lançava uma pergunta [aos tutores], eles davam suas opiniões, achava isto ou aquilo, cada um dava sua opinião e a gente uma decisão e fazer algumas movimentações.

\section{Então eles opinavam a partir de uma estrutura, mas opinavam e você construía com eles também durante o processo...}

Opinavam, eu construía com eles, exato. Mas eles não propunham. Sempre era alguma coisa que já estava sendo discutida e que caminhava. Agora, eles tinham um grau de liberdade total quando estavam na função de tutor, na semana de tutor, de atuarem nos grupos, responderem os alunos. Algumas vezes nós conversávamos em paralelo "olha, fulano disse isso, vai lá, pega aquilo e fala". Ou, então, "ninguém está falando nada, vai lá e bota pergunta".

\section{Era basicamente de informante e dinamizador? [a função do tutor]}

De informante e, antecipadamente, eles sabiam qual era o processo que estava acontecendo. E de certa forma eles já criavam um certo clima na sala porque eles já sabiam qual era o tom do processo.

\section{Como dizer que eles eram informantes se você estava presente o tempo todo, estava vendo?}

Porque eles entravam em uma outra estrutura, que era a estrutura do grupo, e os grupos nem sempre estavam no ambiente. Às vezes o grupo tinha MSN, mil outras formas de articulação. O grupo não ficava só no ambiente. Eu também não podia estar onipresente, então eles traziam feelings dos grupos, a gente sempre conversava sobre os processos que estavam acontecendo, qual era a reação das pessoas. O grande desafio, eu disse para eles assim: "até agora eu sei, eu já vivi, sei tudo". Mas quando a gente entrou no CoLearn, eu disse "é ponto zero pra mim também, é território não mapeado". Então, por favor, agora nós três vamos entrar ao mesmo tempo. Nós entramos duas semanas antes [das aulas] no CoLearn e preparamos o ambiente junto com a Alessandra, o Saburo e todo mundo. Fizemos videoconferência antes... Tanto que quem deu o maior impulso foi a Teresa, que ficou direto com a Alessandra. A montagem, o trabalho no CoLearn foi muito um projeto dos quatro. Então, quando era o Moodle e o Teleduc a coisa era mais dirigida por mim. No CoLearn já foi uma coisa do grupo, um processo de construção.

Eles [tutores] eram os colaboradores. Acho que a palavra nem informante nem nada. Eram colaboradores. Colaboravam dependendo do nível exigência, de necessidade que o curso estava vivendo naquele momento. Ou iria viver naquele momento.

No Moodle por exemplo, quando eles começaram, eles já conheciam, já tinha visto o ambiente, então era mais de dinamizar o processo. No Teleduc eles já tiveram uma função muito mais tranqüila porque as coisas estavam mais arrumadas ali, não havia um desafio muito grande, como no Moodle. E no CoLearn, aí sim, foi os 3, principalmente, eu Teresa e Marcelo. Nós três fomos mapear, explorar aqueles ambientes, a videoconferência o mapa que eles têm, todas as ferramentas, os grupos deles, fomos visitando e depois a gente se reunia e 
via o que era legal e decidia se a gente usava, por exemplo, o mapa deles ou continuava com o outro. "Acho melhor a gente continuar com o nosso senão vai dar muita confusão. Usa a videoconferência ou não? Não vai dar certo, vamos deixar a videoconferência par a última sessão". Essas coisas a gente foi negociando ali.

\section{Na sua opinião, qualquer membro pode ser professor de uma CVA ou precisa ter algumas características específicas? Quais?}

Depende da comunidade. Mesmo sendo comunidade de aprendizagem depende de foco, depende de objetivo, depende do perfil do grupo. Não há como a gente definir uma regra geral. Comunidade de aprendizagem é um nome extremamente amplo para qualquer coisa, para tudo aquilo que se faz em grupo com intuito de aprender dentro de um ambiente virtual. E aí você pode ter grupos totalmente autônomos, onde cada um tem um nível de conhecimento altíssimo e pode de certa forma conduzir o processo em um determinado momento e passar o bastão pro outro como você pode ter comunidades totalmente heterogêneas e que tem uns que predominam tem outros que não, tem os grupinhos, tem de tudo. Mesmo grupo de pesquisa, autônomos, sérios, a coisa se fractaliza, se distribui.

Acho que a comunidade de aprendizagem ela precisa ter uma liderança porque o processo de aprendizagem exige um caminho, uma meta, ele tem um objetivo definido e precisa ter alguém que faça esse processo caminhar, que tenha realmente uma definição de processo.

\section{Esse líder teria algumas características específicas?}

De plano geral não dá pra saber. Há um livro "Design virtual community", coletânea de artigos que apresenta diferentes comunidades virtuais, entre elas algumas de aprendizagem, mostrando que não há uma tipologia, um esquema que define, é muito qual é o objetivo e quem são os participantes.

\section{Um dos objetivos do curso, que consta na ementa, era os alunos vivenciarem uma comunidade de aprendizagem.}

\section{a) Por que havia este objetivo?}

Porque o que eu acredito e os cuidados durante o processo e tudo mais é de que eles pudessem participar de uma cultura. Não adianta, você não aprende sobre o que é uma comunidade somente lendo nos livros. É preciso viver, é preciso estar dentro. Eu tenho horror quando eu vejo uma disciplina que fala de comunidade virtual de aprendizagem e que é presencial ou que é online, mas os alunos estão sentadinhos no laboratório cada um no seu computador, ponto zero.

\section{Mas por que é importante vivenciar uma comunidade?}

Porque para mim qualquer sala de aula precisa ter, faz parte até da proposta teórica colaborativa que se baseia na formação de comunidades, na troca com o outro. Toda proposta teórica de aprendizagem que começa com construcionismo, que conduz a um processo de colaboração, consiste em formar uma comunidade, onde as pessoas possam ter confiança para trocar, se você não tem uma você não consegue chegar a outra. E elas todas para mim 
representam diferenciado, assim como também o Lévy acredita, como Kerckhove também defende, como o Jekins também diz, é uma nova visão de processo, de educação.

Nós vivemos dentro de uma cultura individualista, personalizada, cada um tinha que resolver suas atividades dentro de um processo totalmente fragmentado, onde o aluno é um ser isolado. A avaliação é isolada, o estudo dele é solitário e a própria equipe docente de qualquer lugar escola, faculdade - é uma equipe onde um não sabe o que o outro faz. E nós sabemos hoje que esta não é uma preparação para a sociedade atual. E todas essas metodologias e todas as aprendizagens envolvem trabalho em equipe. E como chegar ao trabalho em equipe simplesmente no ler? Você lê 500 mil livros, mas você nunca participou disso, você nunca viveu intensamente o que é você estar dentro de um grupo onde seus colegas estão a setenta kilômetros de distância de você e você tem que operar com eles, chegar a alguma coisa com eles.

Viver a liderança rotativa, que também vem de um processo pós-curso, nós montamos uma comunidade, tem "n" comunidades de que eu participo, isso aí em 2001, 2002, foi uma coisa que nós definimos no nosso grupo de comunidade, que existe, que isso aí era muito importante. Fomos, inclusive, experimentar essa possibilidade de que os alunos pudessem vivenciar, nem que fosse uma semana a oportunidade de liderar os colegas na execução de um desafio. Porque na verdade estamos falando de uma mudança não apenas cognitiva, mas de uma outra percepção do que é educação do que é ensinar e aprender.

Envolve uma nova cultura educacional, que tem atitudes e valores diferentes, comportamentos diferentes. Pra você poder aprender a viver e chegar, inclusive às questões do Delors, de que você tem que aprender a conhecer, aprender a fazer, aprender a viver, isso tudo se aplica, dentro desse processo. Delors é de 1999 e tudo isso você precisa para aprender a fazer, aprender a viver, aprender a ter atitudes dentro da comunidade, de respeito ao colega e ao que ele pensa e mesmo com as diferenças, conseguir chegar ao resultado, você adquirir valores diferenciados. Não adianta você ficar aprendendo tudo isso dentro de uma sala de aula e depois fazer uma monografia para entregar ao professor. É toda uma informação e teoria righ tech dentro do castelo medieval.

\section{b) Os alunos constituíram uma CVA?}

O meu livro de 2003, que tem alguns capítulos baseados naquela reflexão, tem um artigo, que é o oito "O Ensaio da nossa orquestra" onde eu já falo sobre isso.

\section{Mas minha pergunta diz respeito à turma EAV1 de 2008...}

Mas exatamente o que eu quero dizer é que neste artigo eu já digo o que é uma comunidade. $\mathrm{E}$ aí vai muito do Steven Hanar que criou uma das primeiras comunidades virtuais em 1985, ainda no DOS, que era Psicoloq, que dizia que uma comunidade, quando chega a 90, eu saio que ela não precisa mais de mim, ela já tem gente demais, ela pode seguir sozinha.

A comunidade não é uma estrutura física, não é um prédio, o Rheingold também fala, não é um processo permanente. A comunidade pode acontecer em uma semana, em um determinado desafio, em um determinado momento em que aquele grupo - aí eu diria alguns grupos, algumas pessoas reunidas - elas se constituíram num processo. Eu não posso responder e não posso avaliar a turma inteira. É dificílimo, é impossível, se pensar em uma construção, em um casamento de "viveram felizes em comunidade para sempre". Isto não existe. Essa é uma 
construção cultural e quando as pessoas estão ali, unidas, com o mesmo objetivo, articuladas. Essa semana mesmo, lá no DI (curso Design Instrucional), na minha disciplina eu vi uma palavra lindíssima. Eu fiquei tão feliz com uma frase que uma aluna disse: "Gente, eu já nem sei mais quem é o líder da semana. Eu só estou aqui ajudando." E chegou num ponto em que todo mundo tava fazendo. Chegou no ponto, é como se você estivesse em um processo de ebulição e, num momento, você conseguiu.

Agora você vê até que quando chegou na $3^{\mathrm{a}}$.unidade e houve a dispersão e aí já não tinha mais comunidade. Eu vejo que, no momento da construção da comunidade foi entre o $2^{\mathrm{a}}$. e o $3^{\mathrm{o}}$. desafio da $2^{a}$. unidade. Foi o momento em que eu senti que os alunos estavam integrados, que estavam no desafio e procurando resolver alguma coisa. Mas não a disciplina como um todo.

Diríamos, então, que era uma rede de aprendizagem que em alguns momentos o grupo se comportava como uma comunidade?

Isso.

\section{c) E como você identifica estes momentos?}

Pelas próprias falas deles. Você tem, dentro dos ambientes, todas as ferramentas de acompanhamento permanente. E você sente quando a comunidade constrói, quando no wiki todo mundo ta ali colocando uma corzinha e produzindo texto. Quando no fórum, um complementa o outro e existe interlocução, e não uma pergunta-resposta ou uma fala de surdos, onde um fala uma coisa, outro diz outra e outro diz outro. Onde existe engajamento, onde as pessoas estão se entendendo e o que uma fala é para construir, para complementar o que outra já disse é para amadurecer a idéia e elas estão juntas refletindo sobre alguma coisa. Estão juntas construindo alguma coisa. Aí você tem realmente uma comunidade, um grupo com objetivo definido e que, a realização desse objetivo, acrescenta muito para cada um dos que estão participando. É um movimento. E justamente por ser movimento ele não pode se cristalizar, ele não se cristaliza. Naquele momento aconteceu isso, mas é um momento.

Mas e a questão dos laços? Os grupos do curso desenvolveram laços estreitos e esses laços não são momentâneos.

Mas aí é outro tipo de comunidade que você vê.

\section{Mas os laços foram confeccionados a partir de uma proposta de aprendizagem...}

Sim, você criou redes, naquele momento houve uma comunidade, você criou laços, criou redes, interlocuções diferenciadas com muita gente e, a partir dessas interlocuções, você cria grupos de afeto, que não, necessariamente, precisam estar desenvolvendo alguma coisa em comum.

\section{Mas aí você está atrelando comunidade a uma criação comum e não aos laços fortes...}

O fato é o seguinte: comunidade virtual é uma coisa e na comunidade virtual existe, por exemplo: eu tenho minha comunidade lá que tem professores da Grécia, de Cipre, e que de vez em quando some todo mundo. Leva meses e meses e ninguém fala. De repente, um fulano lá da Finlândia manda uma mensagem e aí a coisa eclode. Parece que está todo mundo dormindo, eu mando uma mensagem e pronto! Leva uma, duas semanas todo mundo falando, 
discutindo aí, de repente, esvazia de novo. A gente sabe e aí é muito no sentido da latência que o Lévy fala, do potencial, que existe ali, num tá morto. Ele existe, mas não é de aprendizagem.

O que você está dizendo é que nas comunidades em geral, são os laços; nas de aprendizagem é a construção? $O$ que caracteriza que naquele momento eles agiram como comunidade, como você disse?

Comunidade de aprendizagem.

\section{Por que construíram algo juntos?}

Porque eles obedeceram naquele momento aos ideais dos princípios do construcionismo e da abordagem colaborativa de aprendizagem. Eles trocaram informações com o intuito de aprender e de o outro aprender também, de construir junto o conhecimento. Eles criaram algum conhecimento a partir do que cada um sabia. É o princípio primeiro das abordagens teóricas.

\section{Mas durante o curso eles estão lá o tempo todo trocando idéias...}

Trocando idéias, mas não, por exemplo, assumindo e realizando um desafio. Trocar idéia não significa se preocupar com o outro e construir com o outro. Ele simplesmente opina. Uma coisa é ter uma pergunta - inclusive é uma coisa que eu e a Paula estamos ralando para poder sair, por exemplo, da pergunta do Fórum. Porque ele ainda reproduz o processo clássico de professor pergunta e aluno responde. Romper com isso para chegar ao plano da conversa, que não é pergunta e resposta, mas é complementaridade, é troca, é o objetivo de alcançar um fórum bem colocado, bem feito. Mas para isso é preciso que haja sinergia, conhecimento, que haja uma proposta, onde as pessoas também não tenham medo de se expor, é preciso criar uma cultura.

Por que eu vou dizer que a comunidade chega na segunda unidade? Porque no primeiro ainda era um princípio onde todo mundo estava se conhecendo. Eles estavam ali. Tanto é que eu me lembro muito da Wanderlucy que disse na primeira unidade que estava muito feliz com seu grupo, mas que estava sentindo estar perdendo algo porque não estava conhecendo os demais colegas dos outros grupos. Aí me deu vontade de rir, "aguarde Wanderlucy, deixe chegar a unidade 2 e você vai ver".

O movimento de ruptura que eu provoco na segunda unidade, ele é totalmente deliberado. Primeiro, existe todo um discurso pedagógico dizendo que tem que se preparar para a mudança, mudança, mudança. É viver a mudança na sua própria história! Então, quando as pessoas entram naquele estado de desequilíbrio, porque tem que mudar de grupo, elas estão há três semanas se integrando e, de repente, elas se desestruturam de tal jeito - porque a cultura tão forte, tão forte que em um mês elas já se integraram ali, elas criaram uma crosta e aí fizeram de cada grupo daquele uma mônada. Então, quando entra no segundo, o que que a gente faz? Entra num princípio de cosmo-visão, onde cada um que vai par novo grupo representa a história de um grupo do qual ele emergiu. Então, em cada grupo se criou o princípio de cosmo-visão onde todos que estavam ali sabiam das interfaces e tinham as interfaces em todos os grupos.

A comunidade se formou apenas nos grupos? E os espaços coletivos? 
Eu acho que na segunda e na terceira semana da segunda unidade, a turma se comportou [como comunidade], amadureceu. Porque a turma já se conhecia.

\section{Enfim, a EAV1 se constituiu como comunidade.}

Naquele momento. Quando eles formaram novos grupos, eles passaram a conhecer todos os grupos, todas as pessoas, estavam interagindo de uma forma mais aberta, com maior, vamos dizer, fluência, por todo o pessoal. Eles começaram a ganhar confiança pra poder dizer o que eles queriam, começaram a entender a lógica do processo. E aí eles perderam o medo, romperam com as tradicionais formas, como as pessoas se colocam dentro da sala de aula tradicionais. E eles passaram a se abrir mais. Pessoas de dentro da sala já vieram prontas para isso, logo na primeira semana, mas isso não foi o comportamento geral, no primeiro módulo. Teve muita gente muito tímida e aos poucos foram adquirindo confiança até que num certo ponto eles nem lembravam que tinha professor. Eles já estavam mais quentes, querendo debater.

Um dos aspectos que eu também posso pensar nesta história é que o assunto, o tema da segunda unidade, que era Ensino, era mais pertinente a essa discussão, uma vez que todos de certa forma tendiam para a Educação. Você falar de ensino, de teorias de aprendizagem, de abordagens colaborativas, já era alguma coisa que eles previam que ia acontecer. Não era como a unidade Tecnologias. $\mathrm{O}$ assunto talvez tenha facilitado mais. Você vê a coisa crescendo, crescendo e, de repente... termina a segunda unidade e aí a proposta [terceira unidade] é entrar num outro ambiente, também desafiador, mas você sente que houve uma queda, um esfriamento. Como eles estavam muito preocupados com o projeto [proposta da $3^{\mathrm{a}}$. unidade], o final do semestre e tudo mais, cada um voltou a sua individualização e aí no $3^{\circ}$. Momento você não vê mais a comunidade atuando. Você vê os projetos de cada em seu micro-grupo, ou quem tava fazendo trabalho individual, mas a partilha a troca, o desejo de construir junto já não tinha mais.

Aí você vê a comunidade criando novas comunidades de aprendizagem com seus alunos [por conta dos projetos implementados], eles trazendo informações e trazem informações pra mim até hoje.

Assim, no início, na $1^{\mathrm{a}}$. unidade, as pessoas estavam se conhecendo. Então era rede [a EAV1] porque todo mundo estava querendo descobrir o ambiente e as pessoas. $\mathrm{O} 2^{\circ}$. momento é o mais crítico, mais importante do processo. No $3^{\circ}$., criam-se laços, redes afetivas. Agora essas redes, no $2^{\circ}$. momento, e no processo inteiro o que agente pode dizer que não era só a questão de conhecimento, é verdadeiro "cha": comportamentos, habilidades e atitudes, e valores. Então, na verdade, o processo de aprendizagem...

Então, a diferença em relação ao defendido nesta dissertação é de que, para nós, as de aprendizagem, seja rede ou comunidade (onde há laços estreitos), seriam as que possuem a presença do professor, uma proposta de aprendizagem, $e$ um objetivo educativo a ser alcançado. Mas para você, pelo que eu estou entendendo, as de aprendizagem são quando há construção de conhecimento.

$\mathrm{Na}$ EAV isso é claro porque, na verdade, estamos ali com pessoas trabalhando com assuntos que não são totalmente do desconhecimento delas e em níveis diferenciados. 


\section{Mas uma rede não pode construir conhecimento também?}

Pode, mas não forma comunidade. Você pode, você vive a vida inteira trabalhando em equipe e formando redes, agora pra chegar a ser comunidade é outra conversa. É um tipo de trabalho que é feito com pessoas em rede, mas que elas não estão preocupadas em formar comunidade. É um trabalho onde distribui: você faz isso, você faz aquilo e chegam a um resultado e aprendem. Você aprende de todo jeito, você aprende sozinha.

\section{Mas você não atrela o surgimento da comunidade à construção de conhecimento?}

Não é só isso. Aí é que está. O momento de amadurecimento das relações, do conhecimento, comportamento, valores, atitudes, hábitos, tudo isso amadurecido num processo coletivo orientado para chegar à superação de um desafio. Esse desafio não estava neles, e aí é o papel do professor. O papel do professor é poder trazer o desafio que realmente mobilize as intenções, as motivações de todos, para que juntos possam superar aquele desafio. Agora, o desafio vem de algum lugar. Se eu for esperar os alunos, bom tai, agora façam, não fazem. Olha o tema é este, o tema é este aqui. Agora vocês se reúnam em grupos e façam o trabalho. O que vai acontecer? Cada um vai pegar um pedacinho, vai juntar, este é o trabalho de equipe que todo mundo conhece.

Agora, o que diferencia o trabalho na comunidade? É a vontade de estar ali, de resolver, de desafiar, de ir além, trocando idéias com o outro, colaborando com o outro. Um escreve um pedaço o outro vai lá remenda, complementa, discute no fórum. Quero dizer que todo esse processo é um processo de uma construção coletiva, que aquilo que o Lévy cansa de colocar nos livros dele. É você vivenciar essa construção para chegar a isso, nós temos que superar, nós temos que ir muito além da relação de laços afetivos e de conhecimento.

Nós temos que ter valores, temos que ter respeito ao outro, temos que ter atitudes, temos que ter habilidades, temos que outros tantos comportamentos que sejam significativos para que essa comunidade aconteça. Se a gente pensar só em laços afetivos e conhecimento a gente continua na equipe. Não sai disso: eu sou amiguinha de você, temos que fazer o trabalho da professora tal, então você faz a capa e eu faço o conteúdo, você faz o capítulo 1 e eu o 2 . Depois a gente reúne para fazer as considerações finais e pronto. Isso daí não é comunidade! Por isso, comunidade é uma coisa muito difícil de ser alcançada. Exige uma mobilização de sentidos muito maior, de expectativas, de muitas coisas para poder se chegar naquele movimento.

É um processo. Você vai, vai e aquilo dali [EAV1] é uma grande aprendizagem porque aquela aprendizagem ali não vai ser nunca igual, mas de certa forma ela replica e as pessoas saem dali com outro olhar, que não é apenas a aprendizagem verborrágica do conhecimento. É alguma coisa que se plantou como algo construído, como algo aprendido, em todo o sentido da palavra que significa "aprendizagem", que envolve, no caso Delors, aprender a ser, aprender a conhecer, aprender a fazer... Esse é o grande processo que está envolvido, e aí é gigante.

\section{O surgimento da comunidade virtual de aprendizagem foi espontâneo ou resultou do esforço e das estratégias adotadas pelos professores?}

Com certeza. 


\section{E quais foram essas estratégias?}

Todas essas, esse princípio, e basear-se no currículo em espiral do Bruner que já recupera Decroly e que faz todo o encaminhamento de uma reflexão. Na verdade os desafios, se você notar, normalmente eles tinham a mesma relação. Eles vinham sempre do mesmo processo: era um desafio individual, que se baseava numa reflexão, essa reflexão encaminhava para o desafio grupal, que encaminhava para uma resposta, que caminhava para os comentários com as pessoas já mais amadurecidas. Quer dizer, você ter um olhar externo para a sua produção, senão você fica fechadinho na sua comunidade. E aí você vê o princípio dialético de você ter uma questão, uma pergunta, trabalhar para analisar aquilo, ter a resposta, que vai te dar o que? Novas perguntas e você vai reelaborar o processo todo. Só que esse currículo em espiral vai se adensando e se aprofundando.

Ele começa lá em cima com as tecnologias. Dentro dessa metodologia, num outro processo, ele vai continuar acontecendo desse mesmo jeito, mas com outras questões, cada vez mais profundas, até você chegar no aprofundamento dentro do seu próprio projeto, da sua própria questão, daquilo que de certa forma você está interessado em aprender, ir além ou aplicar tudo aquilo que já foi aprendido nos momentos anteriores.

\section{Por isto tinha sempre um produto final nos grupos?}

Isso, que é a volta da espiral. Então, qual é o princípio? Ela começa com uma introspecção, é um momento da intra-comunicação (você com você mesmo) pensando sobre aquilo, lendo, indo atrás e vendo tentando dar uma resposta individual, que será somada a dos seus parceiros e vai dar uma resposta em equipe. [FABULOSO] Essa resposta em equipe vai ser explicitada para o mundo a partir de uma finalização, seja um trabalho, uma apresentação, um Power Point, um mapa. Esse resultado tem que entrar na visão do mundo. Aí o outro vem e dá o feedback pra você. Esse processo todo vai de certa forma o próprio desafio.

Então o desafio seguinte, de certa forma, ele habilita toda essa construção, para um outro olhar, um outro tema e o temas vão se aprofundando na medida em que você vai fazendo. Tanto é que a semana na unidade de Tecnologias, para trabalhar com mapa, e o mapa era da sua história, da sua vida. Depois tem o wiki, a teoria, o projeto... A construção, você vai aprofundando usando todas as ferramentas até o ponto em que você supera as ferramentas, passa a estar no lugar dela, entende que está ali para ajudar você a aprender mais e melhor e fazer com que haja uma maior interação entre você e todos.

\section{Você já foi professora em outras CVAs? Se sim, o que a sua experiência mostra: as comunidades virtuais de aprendizagem são "provocadas" ou não?}

Sim, são. As comunidades virtuais não são provocadas. As de aprendizagem são muito específicas, pelo próprio fato da aprendizagem ser uma coisa que a Educação sempre deixou de lado. O sistema educacional todo está pautado em ensinar, que é o que o professor faz. $\mathrm{O}$ que isso representa do lado do aluno, o que ele aprende, como ele aprende, por que ele aprende e o que ele vai levar de aprendizagem, isso não existe uma disciplina na Educação que ir fundo nisso.

\section{Só na Psicologia?}

Nem na Psicologia, que ainda está algumas décadas atrasadas nisso, porque ainda está, vamos dizer, num viés comportamentalista, de ratinhos etc. 


\title{
APÊNDICE C - Questionário respondido pelo tutor Marcelo Gozzi
}

\author{
1. Qual a sua função no curso EAV 1 e que atividades realizava? Como era a dinâmica entre \\ a professora e os tutores do curso para acompanhamento e proposição das atividades?
}

Na disciplina EAV1 eu exerci duplo papel: fui aluno e fui tutor. Como aluno, participei de todas as atividades propostas, individuais e coletivas, juntamente com os demais alunos. Como tutor, nosso trabalho iniciou três meses antes do início da disciplina. A profa. Dra. Vani Moreira Kenski fez diversas reuniões com os tutores no intuito de expor as propostas para a disciplina e planejar a atuação dos tutores. Durante a execução da disciplina, a tutoria era compartilhada entre os três tutores, com trocas semanais. Porém, os tutores e a Professora Vani mantinham contato constantemente, visando conseguir um acompanhamento efetivo das ocorrências em todos os instantes da disciplina, para correção e ajustes nos rumos.

2. Um dos objetivos do curso, que consta na ementa, era os alunos vivenciarem uma comunidade de aprendizagem. Este objetivo foi alcançado, ou seja, os alunos constituíram uma CVA? Quais razões o(a) fazem pensar que houve ou não esta formação?

Pude perceber a formação de várias comunidades de aprendizagem nesta disciplina. Algumas, com duração até o final de alguma atividade proposta. Outras, que duraram o curso todo. E outras, que se estendem até os dias de hoje. Se considerarmos que, em linhas gerais, existe uma comunidade de aprendizagem sempre que existem objetivos comuns a serem atingidos, sempre que as pessoas sentem-se pertencentes à comunidade e sempre que existe o sentimento de co-responsabilidade pelos resultados alcançados pelo grupo, podemos afirmar que houve vivência em comunidades de aprendizagem através da disciplina EAV1 - 2008.

3. (Se a resposta anterior for positiva) O surgimento da comunidade virtual de aprendizagem foi espontâneo ou resultou do esforço e das estratégias adotadas pelo professor e tutores? Quais foram?

O surgimento das comunidades virtuais de aprendizagem foram favorecidos pela atuação da Professora e dos tutores, desde a concepção e planejamento do curso até o acompanhamento completo da disciplina. Sem a adoção de estratégias que visavam viabilizar a aproximação e instigar a participação dos participantes da disciplina, a formação de uma comunidade virtual de aprendizagem ficaria comprometida, podendo até não ocorrer. Como exemplos dessas estratégias posso citar: a proposta de constituição da identidade dos grupos iniciais; o rompimento desses grupos e a proposta de formação de um novo grupo; a dinâmica de proposta de atividades individuais e coletivas; a proposta de avaliação contínua e formativa na disciplina.

4. Você já foi professor ou tutor em outras CVAs? Se sim, o que a sua experiência mostra: as comunidades virtuais de aprendizagem são "provocadas" ou não?

Sou professor e atuo em cursos presenciais, a distância e híbridos. Nas experiências dos cursos virtuais, já presenciei formações de comunidades de aprendizagens. Sempre que ocorreram essas formações, elas foram "provocadas" pelo professor/tutor, através da adoção de estratégias que visavam a mediação pedagógica das interações entre os participantes. Masetto descreve as características dessa mediação pedagógica, as quais são discutidas na 
minha dissertação de mestrado, defendida em 2006. Portanto, acredito que a mediação pedagógica favorece muito a constituição de comunidades virtuais de aprendizagem.

5. No curso EAV 1, você foi aluno e tutor ao mesmo tempo. O que aprendeu com esta experiência?

Como aluno, aprendi a conviver em comunidade, desenvolver trabalhos coletivos utilizando os recursos das TICs e aprendi muito com os conteúdos propostos na disciplina. Como tutor, desenvolvi bastante a prática da mediação pedagógica, aprendendo a necessidade de acompanhar constantemente o que acontece com todo o grupo, ficando atento a todos os detalhes, pois esses são dotados de um enorme potencial para o encorajamento para o desenvolvimento do curso. O mediador presente e ativo é um elemento importante para a motivação e o desenvolvimento da aprendizagem em uma disciplina ofertada a distância. TUTOR

6. Na sua opinião, qualquer membro de uma CVA pode ser professor ou tutor ou precisa ter algumas características específicas? Quais?

Acredito que qualquer membro de uma CVA possa assumir o papel de liderança em determinado momento da vida dessa comunidade. Porém, para tornar-se professor ou tutor é necessário ter estudado os conceitos e princípios das abordagens colaborativas em processos educacionais. Determinadas características pessoais dos participantes podem levá-lo a assumir o papel de mediador em uma CVA, mas um profissional devidamente capacitado deve estar acompanhando todo esse processo para garantir o objetivo e a vida da comunidade, considerando o fim para qual ela foi criada. 


\title{
APÊNDICE D - Questionário respondido pela tutora Teresa Jordão
}

\author{
1. Qual a sua função no curso EAV 1 e que atividades realizava? Como era a dinâmica \\ entre a professora $e$ os tutores do curso para acompanhamento e proposição das \\ atividades?
}

Nossa função era a Tutoria compartilhada. Atividades: acompanhamento da dinâmica do curso, das discussões, mediação dos fóruns, apoio aos alunos em suas dúvidas na realização das atividades do curso, dentre outras.

Os tutores e a professora da disciplina se reuniam semanalmente para o planejamento das atividades e ações no ambiente virtual. Nesta reunião, conforme os objetivos da disciplina naquela semana, eram definidas as estratégias e elaboradas as ações de cada tutor, a partir da observação dos alunos na realização das atividades da semana anterior.

2. Um dos objetivos do curso, que consta na ementa, era os alunos vivenciarem uma comunidade de aprendizagem. Este objetivo foi alcançado, ou seja, os alunos constituíram uma CVA? Quais razões o(a) fazem pensar que houve ou não esta formação?

Depende do conceito que se utilizar sobre CVA. Acho que conseguimos sim manter uma dinâmica de uma comunidade virtual de aprendizagem. Mas na minha opinião pessoal, uma comunidade virtual só existe realmente quando ela se mantém mesmo sem a presença formal de um líder (professor) ou sem uma estrutura formal (disciplina). Portanto, EAV1 não deve ser considerada uma CVA.

3. (Se a resposta anterior for positiva) $O$ surgimento da comunidade virtual de aprendizagem foi espontâneo ou resultou do esforço e das estratégias adotadas pelo professor e tutores? Quais foram?

O surgimento deste ambiente virtual não foi espontânea, ela surgiu dentro de uma disciplina formal da pós-graduação e não teve continuidade, por este motivo, não a concebo como uma comunidade virtual, mas sim um ambiente virtual de aprendizagem.

4. Você já foi professor ou tutor em outras CVAs? Se sim, o que a sua experiência mostra: as comunidades virtuais de aprendizagem são "provocadas" ou não?

Já fui tutora e professora em outros ambientes virtuais de aprendizagem e nenhuma delas se tornou uma comunidade virtual, pois só duraram enquanto o espaço formal do curso ou disciplina existiram.

5. No curso EAV 1, você foi aluno e tutor ao mesmo tempo. O que aprendeu com esta experiência?

A experiência é bastante significativa, pois você pode olhar as situações pelos dois pontos de vista. Com certeza, ser também alunos nos ajudou a pensar em estratégias que suprissem determinadas lacunas que surgiram durante o curso. $O$ planejamento durante a ação foi facilitado por esta observação. 
6. Na sua opinião, qualquer membro de uma CVA pode ser professor ou tutor ou precisa ter algumas características específicas? Quais?

Então, reafirmando o que disse anteriormente, não acredito que tais experiências sejam comunidades virtuais.... são sim ambientes virtuais de aprendizagem que tem prazo pra começar e acabar.

Já para uma CVA, acho que qualquer pessoa pode assumir a liderança, em momentos diferentes, ou seja, a liderança compartilhada é uma maneira de conseguir engajamento dos membros e motivação para que continuem participando ativamente da comunidade.

A característica principal do líder é seu envolvimento e motivação para discutir os temas da comunidade. 


\section{APÊNDICE E - Questionário respondido pelo tutor Rodrigo Gabriel da Silva}

1. Qual a sua função no curso EAV 1 e que atividades realizava? Como era a dinâmica entre a professora $e$ os tutores do curso para acompanhamento e proposição das atividades?

Éramos alunos (comuns) matriculados no curso EAV I. Porém a dinâmica da disciplina era participar como tutores até o penúltimo módulo sem que o restante da turma soubesse. Assim interagíamos com o grupo como identidades não reais. Trocávamos discussões e incentivávamos toda a equipe além de tirar as dúvidas apresentadas. Em momento algum houve desconfiança dos alunos em relação aos tutores serem os próprios orientandos da Prof. Vani. As atividades eram propostas pela Prof. Vani, mas sempre tínhamos um encontro antes da aula presencial para tratar dos assuntos que seriam desenvolvidos nas aulas seguintes.

2. Um dos objetivos do curso, que consta na ementa, era os alunos vivenciarem uma comunidade de aprendizagem. Este objetivo foi alcançado, ou seja, os alunos constituíram uma CVA? Quais razões o(a) fazem pensar que houve ou não esta formação?

Sim o objetivo foi alcançado. Diversas áreas distintas unidas em busca de trabalhos colaborativos e vivências em Educação à Distância. Creio que foi constituída uma CVA pelo fato dos trabalhos e a união que os grupos demonstraram ter conquistado na última aula presencial e como todos se conheciam e se comunicavam sem pensar em tempo e distância.

3. (Se a resposta anterior for positiva) $O$ surgimento da comunidade virtual de aprendizagem foi espontâneo ou resultou do esforço e das estratégias adotadas pelo professor e tutores? Quais foram?

Foi espontânea. Diria que a professora e os tutores foram mediadores desta interação. Usávamos a idéia de desequilíbrio, quando todos estavam se acostumando com o grupo e o ambiente, tinham que mudar e começar uma nova jornada. Ninguém criou vinculo com ninguém, todos interagiram sem grupos específicos, este foi o diferencial da disciplina.

4. Você já foi professor ou tutor em outras CVAs? Se sim, o que a sua experiência mostra: as comunidades virtuais de aprendizagem são "provocadas" ou não?

Esta foi a única experiência. Espero contar com mais outras.

5. No curso EAV 1, você foi aluno e tutor ao mesmo tempo. O que aprendeu com esta experiência?

Éramos três tutores. A cada semana revezávamos para não tornar o trabalho muito acumulado. Porém a responsabilidade de incentivar e levantar a turma nas discussões era um grande desafio. Trazer conceitos e indagações era o mais interessante desta função, pois, diversas respostas eram dadas e comentadas por todos. Um rico material teórico.

7. Na sua opinião, qualquer membro de uma CVA pode ser professor ou tutor ou precisa ter algumas características específicas? Quais?

Não, basta fazer o pleno papel de mediador. Motivar as discussões e controlar as conversas para que não fujam do tema. 